UNIVERSIDADE DE SÃO PAULO

FACULDADE DE FILOSOFIA, LETRAS E CIÊNCIAS HUMANAS DEPARTAMENTO DE GEOGRAFIA

PROGRAMA DE PÓS-GRADUAÇÃO EM GEOGRAFIA HUMANA

\author{
JORGE SLEIMAN
}

A INDÚSTRIA AGROPECUÁRIA NA FRONTEIRA NOROESTE DO RIO GRANDE DO SUL

"Versão Corrigida"

SÃO PAULO

2014 
UNIVERSIDADE DE SÃO PAULO

FACULDADE DE FILOSOFIA, LETRAS E CIÊNCIAS HUMANAS

DEPARTAMENTO DE GEOGRAFIA

PROGRAMA DE PÓS-GRADUAÇÃO EM GEOGRAFIA HUMANA

\section{A INDÚSTRIA AGROPECUÁRIA NA FRONTEIRA NOROESTE DO RIO GRANDE DO SUL}

"Versão Corrigida"

De acordo

Prof. Dr. Francisco Capuano Scarlato

São Paulo - SP, de outubro de 2014.

\section{Jorge Sleiman}

Tese apresentada ao Programa de Pós-Graduação em Geografia Humana do Departamento de Geografia da Faculdade de Filosofia, Letras e Ciências Humanas da Universidade de São Paulo para obtenção do título de Doutor em Geografia

Orientador:

Prof. Dr. Francisco Capuano Scarlato

SÃO PAULO - SP 
Nome: SLEIMAN, Jorge.

Título: A INDÚSTRIA AGROPECUÁRIA NA FRONTEIRA NOROESTE DO RIO GRANDE DO SUL.

Tese apresentada à Faculdade de Filosofia, Letras e Ciências Humanas para obtenção do título de Doutor em Geografia.

Aprovado em: Instituição:

Prof. Dr. Assinatura:

Julgamento:

Prof. Dr. Instituição:

Julgamento: Assinatura:

Prof. Dr. Instituição:

Julgamento: Assinatura:

Prof. Dr. Instituição:

Julgamento: Assinatura:

Prof. Dr. Instituição:

Julgamento: Assinatura: 


\section{AGRADECIMENTOS}

A todos os professores, colegas, amigos e familiares que tornaram possível a realização deste estudo;

Especialmente ao meu orientador, o admirado Prof. Dr. Francisco Capuano Scarlato, que acolheu com entusiasmo o tema desta investigação e desde o princípio mostrou-se confiante na condução dos trabalhos;

Aos professores da Geografia da USP, particularmente o Dr. Mário de Biasi, cujo apoio inicial foi decisivo, a Dra. Glória da Anunciação Alves e a Dra. Isabel Aparecida Pinto Alvarez, pelas sugestões de ambas no Exame de Qualificação;

Aos Profs. Drs. Pedro Luis Buttembender, da FIDENE/UNIJUI, e Edemar Rotta, da UFFS, pela valiosa indicação de bibliografia especializada;

Agradecimento especial às Sras. pesquisadoras Zerta Kupske, Tereza N. Christensen e Vera Segat, bem como à Sra. Daniele Parise Germano e aos Srs. Aldo Ritt, Ari Pasa, José Munhoz, Jairton Dezordi, Juscelino Gonçalves, Alcino Neitzke, Oscar Inácio Buttembender e Janir Lino que, amavelmente, me concederam entrevistas, clareando pontos obscuros ou esquecidos da história da indústria em Santa Rosa e região;

Ao pessoal da Prefeitura Municipal de Santa Rosa e da Secretaria de Planejamento, pela cedência do mapa de zoneamento urbano municipal; da Secretaria da Fazenda, pela cedência dos dados de retornos fiscais; da Secretaria da Agricultura, pela leitura dos gráficos de produtividade agrícola de soja, milho e trigo; do Instituto Brasileiro de Geografia e Estatística de Santa Rosa, na pessoa dos Srs. Ivon Adolfo Schaedler e do IBGE de Porto Alegre, na pessoa do Sr. Ademir Barbosa Koucher, pela cedência dos dados de produtividade agrícola de soja, milho e trigo; e ao pessoal dos sindicatos patronais e dos trabalhadores das indústrias de alimentos e da indústria metalmecânica com sede em Santa Rosa;

A Josué Azevedo dos Santos, pela amabilidade em aclarar os termos em inglês;

Ao meu irmão Michel, por ter acompanhado toda a trajetória deste estudo, e às minhas irmãs, Alma e Solange, por seu apoio;

Ao nosso amado pai Joseph, em vida e em memória; e

À nossa amada mãe Georgette, cujo amor e cujo incentivo tocam a todos da família. 


\section{SUMÁRIO}

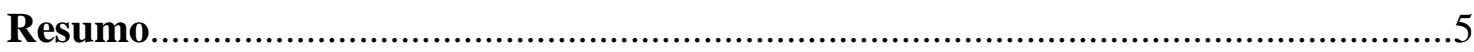

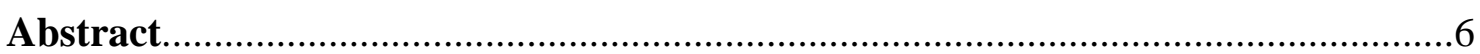

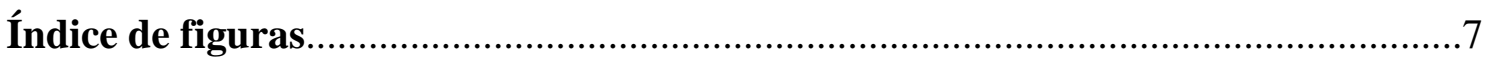

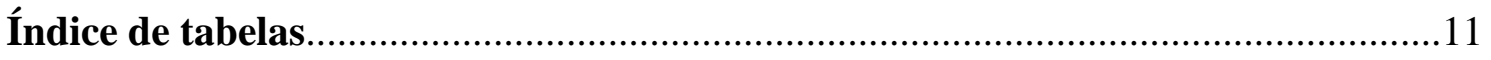

1. Introdução

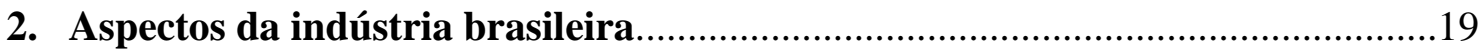

2.1. Extrativismo e manufatura iniciais...................................................................19

2.2. Moldes de uma indústria nacional..............................................................22

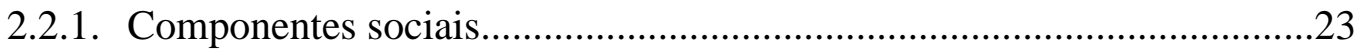

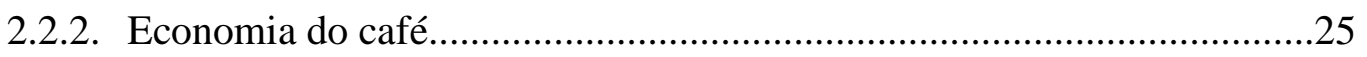

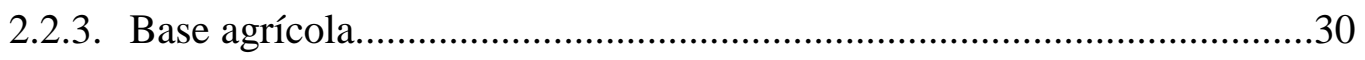

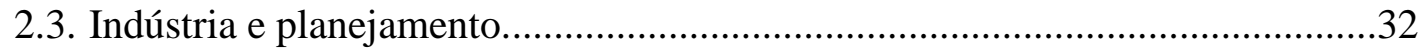

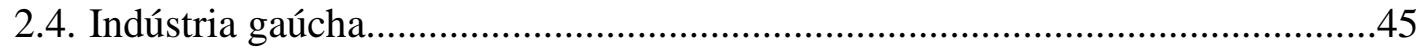

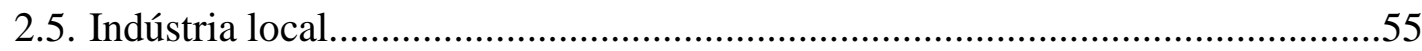

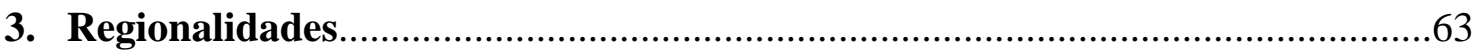

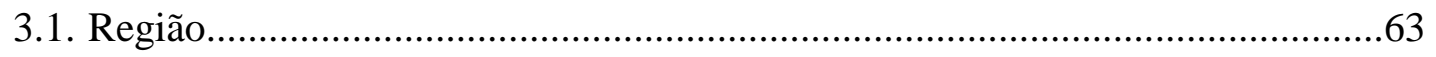

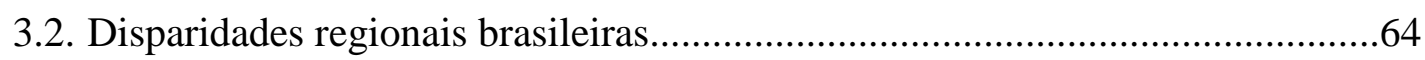

3.3. Disparidades regionais no Rio Grande do Sul................................................72

3.3.1. Arranjos de governança microrregional...............................................82

4. Indústria na Fronteira Noroeste do Rio Grande do Sul....................................87

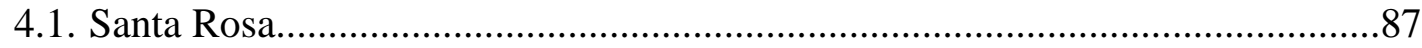

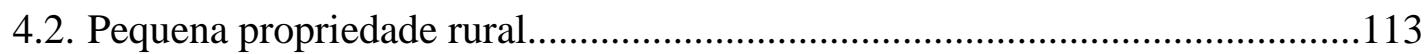

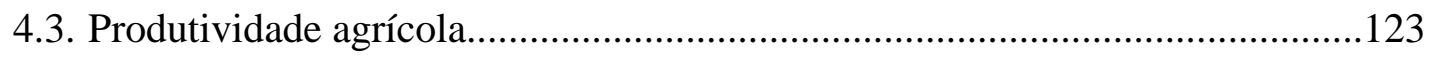

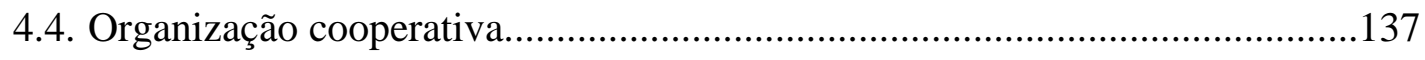

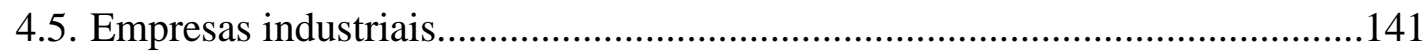

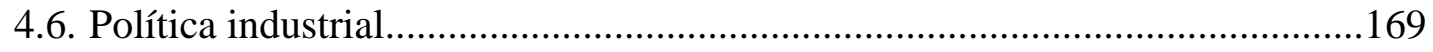

4.7. Sindicatos dos segmentos alimentar e metalmecânico....................................179

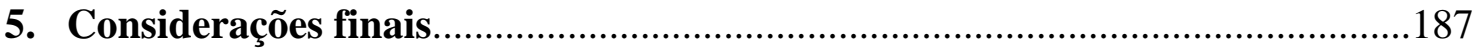

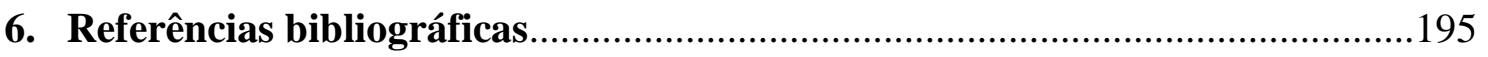




\section{RESUMO}

Este estudo aborda a atividade industrial vinculada à atividade agropecuária de um município de pequeno porte localizado na microrregião Fronteira Noroeste do Rio Grande do Sul, Santa Rosa que, nas últimas décadas, atraiu para sua região de abrangência investimentos industriais ligados à transformação dos produtos gerados pela agropecuária local: a soja, o milho, o trigo, o leite e o suíno, produzidos em grande parte em pequenas propriedades fundiárias. Uma destacada indústria dessa microrregião é a metalmecânica, que teve alicerçadas as primeiras plantas industriais montadoras de máquinas e produtoras de implementos agrícolas já na década de 1950 e que, à medida dos empreendimentos em tecnologia, melhoramento de produtividade no campo e formação de mão-de-obra especializada, tem aumentado a geração de renda na região de estudo. No transcurso de sua economia, a microrregião enfrentou diversos percalços, devidos por um lado ao modelo de produtividade local e, por outro, às dificuldades da política econômica brasileira vigente nos anos de 1980, quando o Governo deixa de subsidiar o setor produtivo primário da região, forçando uma reestruturação de sua economia. As lideranças regionais do RS procuraram estimular a vinda de novos empreendimentos e ao mesmo tempo evitar a fuga de capitais internos, especialmente do setor empresarial e do efetivo humano, consequência da intensificação do êxodo rural rumo a outras áreas melhor posicionadas economicamente. É quando entram em cena as políticas coordenadas que, envolvendo atores sociais, políticos e econômicos, buscaram melhorar a inserção da região nos contextos estadual e brasileiro e culminaram na criação recente dos Conselhos Regionais de Desenvolvimento, dos Arranjos Produtivos Locais e dos Programas de Apoio aos Polos Tecnológicos. O estudo traça uma trajetória dos principais setores dessa indústria local e regional do Brasil, revelando alguns dos aspectos que têm marcado seu avanço entre meados do século XX e os dias atuais.

PALAVRAS CHAVE: Agroindústria; Indústria alimentar; Indústria metalmecânica; Fronteira Noroeste do Rio Grande do Sul; Santa Rosa - Rio Grande do Sul. 


\section{ABSTRACT}

This study addresses the industrial activities of Santa Rosa, a small city located in the North West Frontier micro region of Rio Grande do Sul, and their linking to agriculture. In recent decades, Santa Rosa has attracted industrial investments related to the processing of local agricultural products, such as soybeans, corn, wheat, milk and pork, mostly farmed on small estates. In this scenario, metalworking has played a major role since the foundation of the first industrial plants for the production of machinery and agricultural implements, in the 1950's. It has developed technology, improved productivity and trained specialized manpower, increasing the income generation in the study area. Over the period, however, Santa Rosa region has faced some mishaps. This were due firstly to the local production model, and secondly, to the Brazilian economic policy in the 1980s when the government stopped subsidizing the primary productive sector of the region, which led the municipality to restructure its economy. Regional leaders of Rio Grande do Sul sought to encourage the coming of new ventures and at the same time prevent the outflow of domestic capital, especially the business class and working class, caused by the intensifying rural exodus towards other better economically positioned areas. Coordinated policies involving social, political and economic players then came into play aiming at better integration of the region at the state and national levels culminating in the mid -1990s in the creation of the Conselhos Regionais de Desenvolvimento - COREDES (regional development councils), Arranjos Produtivos Locais - APL (local production arrangements) and Programas de Apoio aos Polos Tecnológicos (programs to support technological poles). The study traces a trajectory the main sectors of this local and regional industry in Brazil, revealing some of the aspects that have marked its development from the mid-twentieth century to present day.

KEYWORDS: Agriculture and livestock; Food industry; Metalworking industry; North West Frontier of Rio Grande do Sul; Santa Rosa - Rio Grande do Sul. 


\section{ÍNDICE DE FIGURAS}

\section{Introdução}

Figura 1.1. Mesorregião Noroeste do RS 13

Figura 1.2. Santa Rosa. .14

\section{Aspectos da indústria brasileira}

Figura 2.1.1. Atividades econômicas no Brasil no século XIX.....................................20

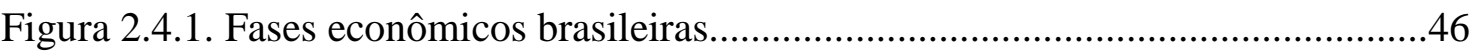

Figura 2.5.1. Os Conselhos Regionais de Desenvolvimento do RS.............................60

\section{Regionalidades}

Figura 3.2.1. Participação industrial por regiões no Brasil em 1970. .68

Figura 3.2.2. Processo de reversão de concentração industrial regional no Brasil, em 1990.

Figura 3.2.3. Distribuição espacial da soja no Brasil, área plantada (ha) em 2006. .71

Figura 3.3.1. Um exemplo de regionalização no Rio Grande do Sul .75

Figura 3.3.2. Taxa de crescimento anual da população nos municípios e no RS entre 2000 e 2010 no RS .77

Figura 3.3.3. Taxa de crescimento anual da população dos Coredes entre 2000 e 2010 no RS .77

Figura 3.3.4. População absoluta por Corede em 2010. .81

Figura 3.3.1.1. Os 28 Conselhos Regionais de Desenvolvimento. .85

Figura 3.3.1.2. As Regiões Funcionais de Planejamento com seus respectivos Coredes .86

\section{Indústria na Fronteira Noroeste do Rio Grande do Sul}

Figura 4.1.1. Os municípios do Corede Fronteira Noroeste. .87

Figura 4.1.2. Zoneamento urbano e sistema viário do município de Santa Rosa...........94

Figura 4.1.3. Número de indústrias dos segmentos alimentar e metalomecânico entre $1970 / 1980 / 1989$. .95

Figura 4.1.4. Distrito industrial (metalmecânico) de Santa Rosa. .96

Figura 4.1.5. Fachadas de metalúrgicas, tipologia que mais caracteriza o Distrito Industrial de Santa Rosa, localizado à margem da rodovia RS 344 .97 
Figura 4.1.6. Fachadas de metalúrgicas, tipologia que mais caracteriza o Distrito Industrial de Santa Rosa, localizado à margem da rodovia RS 344 ........................97

Figura 4.1.7. Distrito industrial moveleiro Ulrich Maske...............................................98

Figura 4.1.8. Número de estabelecimentos industriais por município, em 2007............99

Figura 4.1.9. Arrecadação de ICMS por Coredes no RS.............................................103

Figura 4.1.10. Posição das atividades econômicas, por agrupamento, no ano de

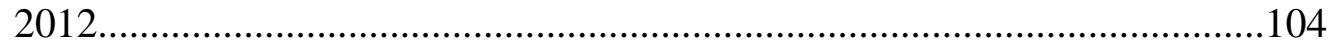

Figura 4.1.11. Participação de Santa Rosa no Valor Adicionado Fiscal (VAF), em 20112012. 104

Figura 4.2.1. Vegetação original no RS................................................................. 114

Figura 4.2.2. Zonas de povoamento no RS desde os açorianos do século XVIII..........115

Figura 4.2.3. Estrutura fundiária no Rio Grande do Sul em 1980..............................116

Figura 4.2.4. Topografia do Rio grande do Sul e de Santa Catarina............................118

Figura 4.2.5. Relevo e macrozoneamento ambiental do Rio Grande do Sul................118

Figura 4.2.6. Número de estabelecimentos rurais de agricultura familiar em 2006.....121

Figura 4.2.7. Estabelecimentos agropecuários latifúndios (não familiares), em 2006.123

Figura 4.3.1. Média de produtividade de soja por município no RS entre 1998 e 2000 . .126

Figura 4.3.2. Média de produtividade de soja por município no RS entre 2004 e 2006. 127

Figura 4.3.3. Produção de soja por estado, médias de 1998-2000 128

Figura 4.3.4. Produção de soja por estado, médias de 2004-2006 .128

Figura 4.3.5. Produção de soja por Corede, média de 2004-2006 130

Figura 4.3.6. Percentual no RS com áreas superiores a 500 ha em 2006. .131

Figura 4.3.7. Períodos com eventos maiores e menores de veranicos (estiagens) entre 1978 e 2005, no Noroeste do RS. .133

Figura 4.3.8. Gráfico evidenciando o rendimento kg/ ha de soja entre 1975 e 2011, em Santa Rosa 134

Figura 4.3.9. Gráfico evidenciando o rendimento kg/há de milho entre 1975 e 2011, em Santa Rosa 135

Figura 4.3.10. Gráfico evidenciando o rendimento kg/há de trigo entre 1975 e 2012, em Santa Rosa. 136

Figura 4.4.1. Identificação, em tom cinza, da Coopermil em seis municípios da então Região Santa Rosa. 139 
Figura 4.4.2. Sede administrativa da Cooperativa Mista São Luiz Ltda em Santa Rosa. 139

Figura 4.4.3. Distribuição das sedes de cooperativas agrícolas no RS, em 2010.........141

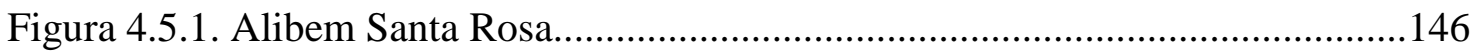

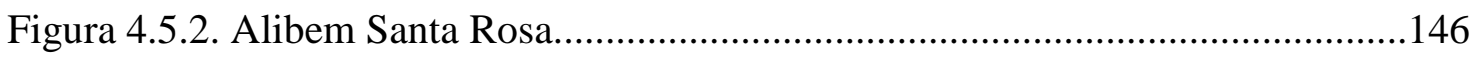

Figura 4.5.3. CCGL Cruz Alta................................................................................. 152

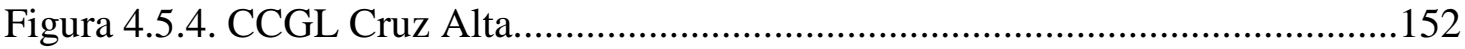

Figura 4.5.5. Exemplares de rebanho leiteiro na Fronteira Noroeste..........................153

Figura 4.5.6. Exemplares de rebanho leiteiro na Fronteira Noroeste...........................153

Figura 4.5.7. Esquema figurado mostrando a evolução da Camera.............................155

Figura 4.5.8. Vista aérea da Camera Agroalimentos de Santa Rosa...........................156

Figura 4.5.9. Massey Fergusson na Feira Nacional da Soja em Santa Rosa................158

Figura 4.5.10. Outdoor (mídia) da Feira Nacional da Soja de 2012 em Santa Rosa...158

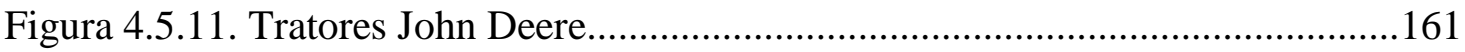

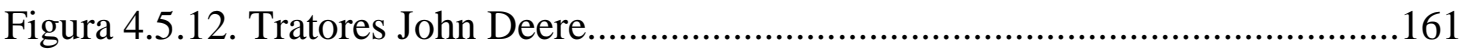

Figura 4.5.13. Modelo de colheitadeira produzido pela John Deere............................162

Figura 4.5.14. Plantadeira John Deere.......................................................................162

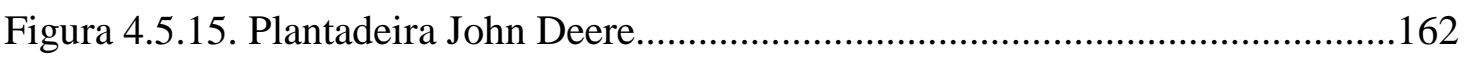

Figura 4.5.16. Vista aérea da John Deere de Horizontina, Fronteira Noroeste............163

Figura 4.5.17. Empresa metalmecânica sistemista do distrito industrial.....................164

Figura 4.5.18. Empresa metalmecânica sistemista do distrito industrial....................164

Figura 4.5.19. Vista aérea da instalação e da linha de produção da AGCO de Santa Rosa. 166

Figura 4.5.20. Colheitadeira Massey Fergusson.......................................................166

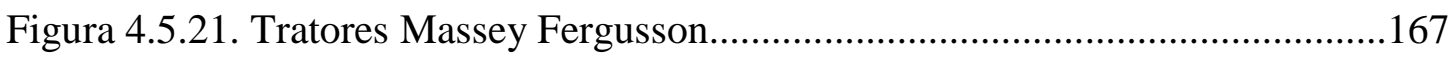

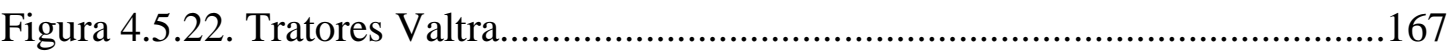

Figura 4.5.23. Implemento agrícola produzido pela Fankhauser em Tuparendi........168

Figura 4.6.1. Núcleos de Extensão Produtivos .........................................................175

Figura 4.6.2. Núcleos de extensão em funcionamento representado pelo ícone de indústria, na cor vermelha e os previstos, na cor verde. 176

Figura 4.6.3. Polos tecnológicos instalados no Rio Grande do Sul...........................178

Figura 4.7.1. Sindicato das indústrias metalmecânicas e de material elétrico de Santa

Rosa - SIMMMERS. 180

Figura 4.7.2. Netz implementos agrícolas, indústria metalomecânica de Santa Rosa181 
Figura 4.7.3. Número aproximado de trabalhadores associados ao sindicato dos trabalhadores da indústria alimentar e metalmecânica 182

Figura 4.7.4. Número aproximado de empresas do segmento alimentar e metalmecânico na microrregião Corede Fronteira Noroeste 182

Figura 4.7.5. Número de trabalhadores na indústria de produtos alimentícios no RS..184 Figura 4.7.6. Trabalhadores do setor metalmecânico no RS, em 2007.........................185 Figura 4.7.7. Número de trabalhadores da indústria do RS, em 2007. 186 


\section{ÍNDICE DE TABELAS}

\section{Aspectos da indústria brasileira}

Tabela 2.2.2.1. Investimento estrangeiro direto, em milhões de libras, em anos

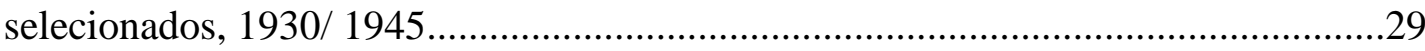

Tabela 2.3.1. Distribuição por setores da atividade industrial.....................................33

Tabela 2.4.1. Número de estabelecimentos industriais entre 1912 e 1920 no Brasil e no RS.

\section{Indústria na Fronteira Noroeste Do Rio Grande Do Sul}

Tabela 4.1.1. Percentual da renda interna de Santa Rosa e estadual entre 1959 e 1980

Tabela 4.1.2. Evolução no número de empresas do setor secundário entre 1970 e 1989

Tabela 4.1.3. Índices percentuais de retorno de ICMS para Santa Rosa entre 1975 e 1993.

Tabela 4.1.4. A evolução da variação percentual do VAF das diversas atividades econômicas em Santa Rosa, entre 1980 e 1990 102

Tabela 4.1.5. Relação das empresas de maior contribuição no VAF do município de Santa Rosa, com base em dados de 2006. 105

Tabela 4.1.6. FPM Interior - Participação dos Estados no total a distribuir. .106

Tabela 4.1.7. FPM - Interior - coeficientes por faixa de habitantes .111

Tabela 4.1.8. Valores (R\$) transferidos para Santa Rosa pelo FPM entre 1996 e 2013.

Tabela 4.2.1. Estrutura fundiária (\%) de estabelecimentos e de suas áreas no Noroeste do Rio Grande do Sul em 1970 e 1995 .120

Tabela 4.5.1. Os estados que mais produzem leite no Brasil..... .154

Tabela 4.6.1. RS: arranjos produtivos locais identificados e apoiados no RS .173 


\section{INTRODUCÃO}

O presente estudo foca a atividade econômica de uma área específica do Brasil, Santa Rosa (Figura 1.1), o município polo da microrregião Corede Fronteira Noroeste ${ }^{1}$ do Rio Grande do Sul, inserida na mesorregião Noroeste do Estado (Figura 1.2). É um estudo de caso singular que investiga a relação intrínseca entre a agropecuária do município santarrosense e as indústrias do segmento alimentar e metalmecânico.

Santa Rosa, atualmente, é o mais desenvolvido dentre os vinte municípios que fazem parte do Corede Fronteira Noroeste, tendo originado e mantido ao longo de seu processo histórico econômico importantes indústrias que se inseriram no circuito do agronegócio brasileiro. Embora Santa Rosa estaja localizada em uma área geográfica mais distanciada dos maiores centros da economia do Rio Grande do Sul, conquistou, nas últimas cinco décadas, notoriedade entre alguns importantes segmentos industriais, sobretudo, os vinculados diretamente à produtividade agropecuária e, num segundo momento, à indústria metalmecânica, instalada estrategicamente na região de estudo.

A soja, a partir de um determinado período, ascende como importante cultura agrícola e recebe maiores investimentos, induzindo os produtores a buscarem áreas de plantio maiores que resultavam em maior produtividade ao longo do processo econômico regional. Notável ainda é que a soja continua tendo uma importância fundamental promovendo o crescimento dos diversos setores da economia local ${ }^{2}$, apesar de ter perdido status de cultura exclusivamente regional. Paralelamente à dinâmica produção agrícola da soja, desponta como coadjuvante na geração de renda local a

\footnotetext{
${ }^{1}$ O Conselho Regional de Desenvolvimento - CRD - “Corede Fronteira Noroeste” corresponde a uma regionalização adotada pelo Governo do Rio Grande do Sul, a partir de meados dos anos de 1990, estabelecendo os Coredes, que atualmente compreendem 28 Conselhos. Mais adiante, neste estudo, há um item acerca desta regionalização.

${ }^{2}$ Situado ante o global, local pode referir-se a uma dada localidade cidade, região ou nação, constituindo, em qualquer dos casos, um subespaço ou um subconjunto espacial, e envolvendo algum modo de delimitação ou recorte territorial, o que se expressa em termos econômicos, políticos e culturais. Usualmente, local tem sido identificado com a ideia de lugar. Dentro de uma acepção geográfica estrita, lugar pode ser definido como uma porção do espaço na qual as pessoas habitam conjuntamente, implicando, portanto a ideia de co-presença. Lugar é associado à ideia de localidade, enquanto cenário físico da atividade social, com uma localização geográfica determinada (LASTRES e CASSIOLATO 2003, p. 17).
} 
produção do rebanho leiteiro e suíno que também deu suporte às nascentes indústrias alimentares locais.

O período coberto por este estudo começa nos meados do século passado ${ }^{3}$, quando teve início a nova fase de industrialização de Santa Rosa, e termina nas décadas mais atuais.

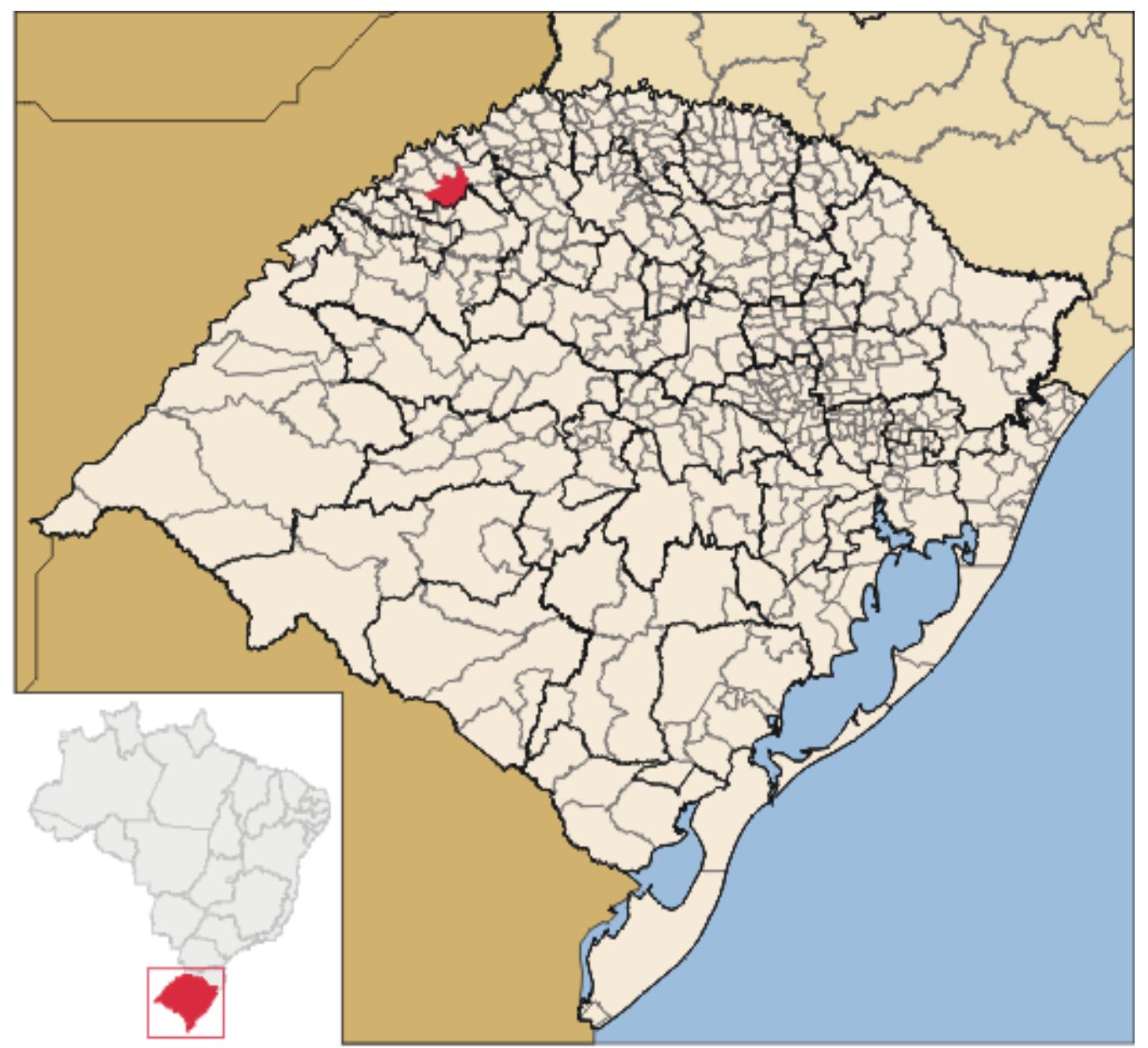

Figura 1.1. Localização do município de Santa Rosa no Estado do Rio Grande do Sul

Fonte: IBGE, 2013

\footnotetext{
${ }^{3}$ As primeiras indústrias de Santa Rosa, que datam do início do século XX, evoluíram a partir de um modelo tipicamente artesanal de processar a erva mate, até a constituição das indústrias alimentares e metalmecânicas fundadas nos anos 1950 e posteriormente ampliadas. Ver Cardoso, 1947; Roche, 1969; Zarth, 1997; Rotta, 1999.
} 


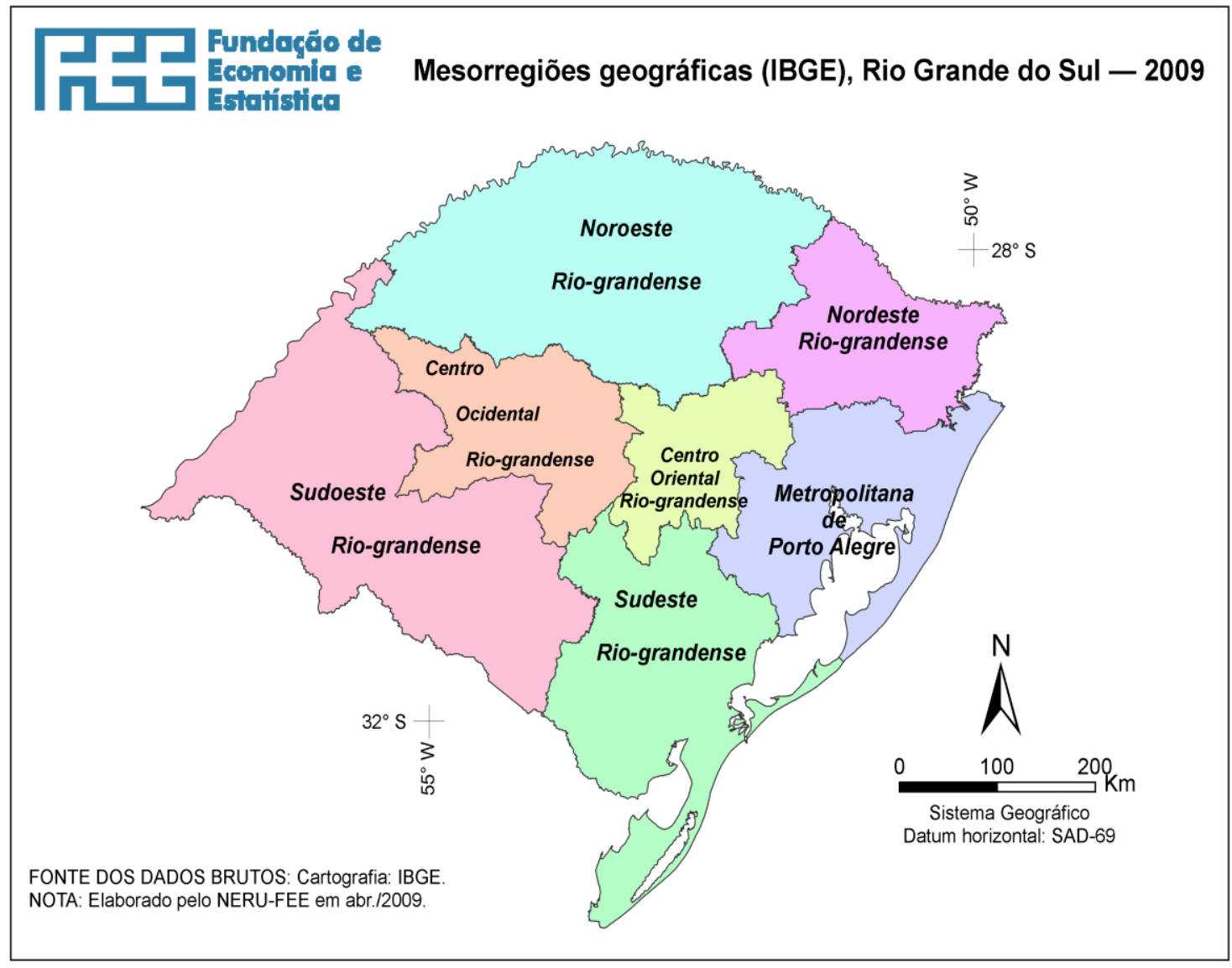

Figura 1.2. As mesorregiões gaúchas, em tom de azul claro observa-se o Noroeste do Rio Grande do Sul.

Fonte: FEE, 2013

Notadamente, a indústria local tornou-se muito importante para a economia contribuindo para o aumento do PIB municipal. Neste estudo, constitui-se em objeto de investigação entender o comportamento dessa indústria, sua importância, as específicidades dela nos contextos econômicos estadual e nacional. Busca-se também entender os elementos responsáveis pela estagnação produtiva que assolou boa parte de pequenas e microrregiões brasileiras cuja maior fonte de recursos concentra-se em atividades do setor primário da economia.

Este trabalho deve trazer um maior conhecimento sobre parte da economia local/regional, o setor secundário, carente de uma investigação que envolva variáveis diferenciadas capazes de dar conta dos objetivos propostos.

Para compreender a inserção de Santa Rosa e sua microrregião no circuito do complexo agroindustrial brasileiro foca-se, em primeiro momento, o desenvolvimento da atividade industrial nos domínios nacional, estadual e regional/municipal. Para isso, 
aproveita-se a bibliografia de Furtado (2010), Prado Jr (1971), Suzigan (2000, 2001), Castro (1972), Oliveira (1981), Fishlow (1977, 2004), Baer (1983, 1996), Cano (1977, 2002), Abreu (1999), Barros (2011), Mamigonian (2005), Mendonça (2004). A leitura revela a que medida o Brasil inseriu-se no processo de industrialização. Após meados do século XIX até os anos de 1930, a indústria se baseava na produção de bens de consumo corrente como de artigos têxteis e alimentícios em detrimento da indústria de bens de capital e intermediário. Porém, a partir da República Nova, o país reúne condições mais efetivas para substituir artigos de sua pauta de importações, na ação convencionalmente denominada "crescimento via substituição de importação", que foi resultado de ações planejadas ou foi imposta pelas circunstâncias, como os choques $\operatorname{adversos}^{4}$ que culminaria, mais tarde, em meados da década de 1950, com Plano de Metas, instituído por Juscelino Kubitschek.

Em segundo momento, a atenção deste estudo se volta à economia regional em âmbito nacional, estadual e local. Visam-se as diferenciações e inter-relações de determinadas áreas nas quais os recursos se encontram distribuídos de maneira desigual, convivendo lado a lado espaços ricos e pobres, dinâmicos e deprimidos. Adota-se a definição de "região" da Nova Geografia, segundo a qual se faz possível a aproximação do local ao global evitando-se a tendência homogeneizante ${ }^{5}$. Desse modo, o espaço local/regional é aproximado ao espaço mais amplo Estado, País, além-fronteiras, estando a análise de determinado aspecto, como as formas de produção, respaldada no dado total. Nesse sentido, o paralelo traçado entre agricultura regional e agricultura nacional identifica formas assemelhadas de produção da economia que levam o analista a um fazer aproximativo e/ou contrastante.

Busca-se também jogar luz numa espécie de regionalização que se estabeleceu no Rio Grande do Sul a partir dos anos 1990, como a criação dos COREDES (Conselhos Regionais de Desenvolvimento), os APLs (arranjos produtivos locais) e o programa de apoio aos polos tecnológicos de desenvolvimento, que acabaram por revitalizar o parque fabril regional. Na perspectiva estadual são tomados estudos que

\footnotetext{
${ }^{4}$ Segundo a teoria dos "choques adversos", a industrialização surgiu como resposta às dificuldades impostas às importações pelos impactos produzidos pela Primeira Guerra Mundial, pela Grande Depressão da década de 1930 e pela Segunda Guerra Mundial (SUZIGAN, 2000).

${ }^{5}$ Ver entre larga lista de autores os trabalhos de Milton Santos, Roberto Lobato Corrêa, Sandra Lencioni, Rogério Haesbaert, citados na Bibliografia, que se valem do materialismo histórico e dialético para comporem seu campo conceitual de uma "Geografia Crítica".
} 
versam sobre a industrialização do Estado gaúcho em concomitância ao processo de desenvolvimento econômico brasileiro, com destaque para Carrion Jr. (1981, 1986), Moreira e Haesbaert (1995), Reichel (1979), Pesavento (1983) e Roche (1969). Na perspectiva regional/local, arrolam-se, entre outros, os estudos de Rotta (1999; 2010), Becker (2000), Becker e Bandeira, 2000); Dallabrida (2000; 2010), Buttembender (2005; 2010), Veiga (2005; 2007) e Andrioli (2010).

O estudo se volta ao desenvolvimento do município de Santa Rosa em fases distintas, revelando-se importantes os dados mais antigos como base para uma avaliação acurada. Trazem-se algumas características intrínsecas regionais quando se faz alusão à questão fundiária com predominância dos pequenos proprietários rurais. Por intermédio de um mapeamento estatístico, evidencia-se a produtividade do trinômio soja-milhotrigo num período que cobre mais de trinta anos da história do município. Ademais, são verificados períodos de extremos climáticos que influíram na produção dessas culturas.

Aborda-se a importância das cooperativas empresariais na administração da produção agropecuária regional. Interessante também é a descrição do rol das maiores indústrias do município de Santa Rosa, pelo qual se conhece a evolução delas através dos tempos e sua contribuição na composição da renda interna do municipio, como por exemplo, os índices de retorno fiscais. Os sindicatos representativos do segmento industrial alimentar e metalúrgico que atuam na região servem como instrumentos para mediação de conflitos entre patrões e operários.

Contudo, não há isomorfia total entre região e economia nacional. Daí que para estudiosos como Becker (2000), Castro (2004), Correa (1989, 1987, 1991, 2006), Haesbaert (2010) a análise exige um procedimento feito necessariamente por "escalas" tomadas como pontos de partida metodológicos de determinado estudo. Por outro lado, não há como num estudo do particular abraçar a complexidade e os desafios do desenvolvimento contemporâneo sem deparar com as limitações da falta de instrumentos técnicos e metodológicos para apreciar qualitativamente a realidade. Será preciso buscar teorias e referências específicas para explicar cada processo singular.

A Nova Geografia que aproximou outros campos do conhecimento à Geografia Tradicional constrói um campo com mais de um referencial, capaz de dar conta dos fenômenos contemporâneos ao valer-se de referências combinadas do saber, como a História, a Sociologia, a Economia e a Administração, permitindo com isso alcançar patamares mais globalizantes na produção do conhecimento. Numa Geografia Econômica, como a deste estudo, muito dos conceitos e das teorias fundamentais - que 
são meios de mensurar fatos e fenômenos - tem sido emprestado, direta e indiretamente, da ciência econômica. Termos tipificados por essa ciência, como demanda interna e demanda externa, renda, rendimento, produtividade industrial, modo de produção etc. povoam os mais diversos estudos geográficos. Metodologicamente, o estudo dessa Geografia pressupõe a utilização de técnicas estatísticas descritivas e categorias econômicas, jurídicas e sociológicas. Espera-se que esses recursos ofereçam condições e instrumentalização para discorrer sobre o tema "industrialização" dentro das especificidades da região em estudo. É de esperar que com o cruzamento desses diferentes ramos do conhecimento consiga-se chegar a um retrato diferencial acerca do tema.

Os dados estatísticos de que se vale este estudo foram obtidos em instituições de ensino, bibliotecas, órgãos públicos governamentais e privados, em empresas regionais e sindicatos representativos de cada categoria profissional e patronal. Para complementação e incremento do estudo foram elaborados questionários de apoio junto às entrevistas direcionadas aos empresários industriais ligados ao ramo alimentar e metalmecânico, aos profissionais ligados à área de produção agrícola (agrônomos) e pecuária, dentre outros. Também foram necessários estudos de casos circunscritos a algumas unidades industriais representativas do segmento alimentar e metalmecânico. Trabalhou-se com a percepção dos colaboradores das indústrias locais (administradores, trabalhadores e sindicatos) com relação ao objetivo e a problemática deste estudo. Houve o contato direto com os funcionários das indústrias para o aprofundamento das questões aqui pertinentes. Para obtenção dos dados secundários foram aproveitados os materiais com informações das empresas, tais como estudos anteriores, relatórios, manuais, dados da internet e estudos de casos com referências bibliográficas.

As pesquisas exploratória, descritiva e explicativa integram as classes de pesquisa que serão escolhidas com base nos objetivos do próprio pesquisador. A pesquisa descritiva tem por objetivo descrever as características de determinada população, fenômeno ou de uma experiência. Esse tipo de pesquisa estabelece relação entre as variáveis no objeto de estudo analisado, variáveis essas relacionadas à classificação, medida ou quantidade que podem se alterar mediante o processo realizado e comumente envolver o uso de técnicas padronizadas de coleta de dados. Quando comparada à pesquisa exploratória, a única diferença que se detecta é que o assunto já é conhecido e a contribuição, a proposta deste trabalho, proporciona uma nova visão sobre a realidade já existente. 
Discorre-se sobre o processo econômico local, abordando-se o desempenho econômico setorial, especialmente o setor secundário; o desempenho fiscal do município; a produtividade agrícola associado aos períodos de extremos climáticos num dado período histórico; a gênese e trajetória industrial brasileira, estadual e local; as diferenciações econômico-populacionais regionais internas no Estado, as políticas de apoio à atividade industrial e o relato das principais indústrias dos segmentos alimentar e metalmecânico.

Procedendo a uma investigação que envolve váriaveis diferenciadas que deem conta do entendimento da evolução das indústrias que mais participam do crescimento de Santa Rosa e da microrregião Fronteira Noroeste do Rio Grande do Sul, e tomando para base de apoio os dados do importante setor agropecuário local, este estudo espera contribuir para um melhor conhecimento dessa indústria regional no Sul do Brasil. 


\section{ASPECTOS DA INDÚSTRIA BRASILEIRA}

\subsection{EXTRATIVISMO E MANUFATURA INICIAIS}

Muito antes da industrialização brasileira, era o tempo da não industrialização, aquele em que o Brasil era colônia de Portugal, a ele pertencente pelo Pacto Colonial ${ }^{6}$. De acordo com esse pacto, a Metrópole Portuguesa tinha exclusividade para comercializar gêneros tropicais, de alto valor no mercado europeu, que daqui eram extraídos ou produzidos em larga escala, como os minerais e os produtos agropecuários: ouro, sal, açúcar, gado, pau-brasil, drogas do sertão (Figura 2.1.1).

A produção extensiva de alguns produtos agrícolas justifica-se pela grande necessidade de obtenção de lucros por parte da Coroa Portuguesa que comandava a economia do País. Pela lógica desse sistema, todos os recursos disponíveis na colônia, desde terras e dinheiro até a mão-de-obra, por esta ser uma mercadoria comercializável, deveriam ser canalizados para a produção extensiva, da qual a chamada agroindústria açucareira nordestina dos séculos XVI a XVIII foi o principal exemplo (MENDONÇA 2004, p. 8).

Algumas manufaturas conseguiram, de certa forma, florescer, sobretudo no ramo de tecidos nas primeiras décadas do século XIX. Na década de 1840, já havia um importante núcleo de indústrias têxteis situado na Bahia, em torno da fábrica de Todos os Santos, que empregava maquinaria importada e trabalhadores livres, produzindo anualmente um milhão de metros de tecidos. No Rio de Janeiro, no mesmo período, a presença de fábricas, modernas para a época, também é registrada, como a fábrica Andaraí Pequeno que tinha 22 operários livres e 459 fusos, e a Santa Tereza, em Parati, que produzia 500 mil metros de tecidos ao ano (MENDONÇA, 2004, p. 14; ROCHE, 1969).

\footnotetext{
${ }^{6}$ Pacto Colonial foi um sistema de leis e normas que as metrópoles impunham às suas colônias durante o período colonial, estas leis tinham como objetivo principal fazer com que as colônias só comprassem e vendessem produtos de sua metrópole. O pacto colonial incluiu obediência política, ou seja, as leis a serem obedecidas deviam ser as mesmas leis (ou adaptadas) da metrópole correspondente à colônia. $\mathrm{O}$ objetivo das autoridades reais era garantir que as atividades econômicas da colônia gerassem lucros para a metrópole.
} 


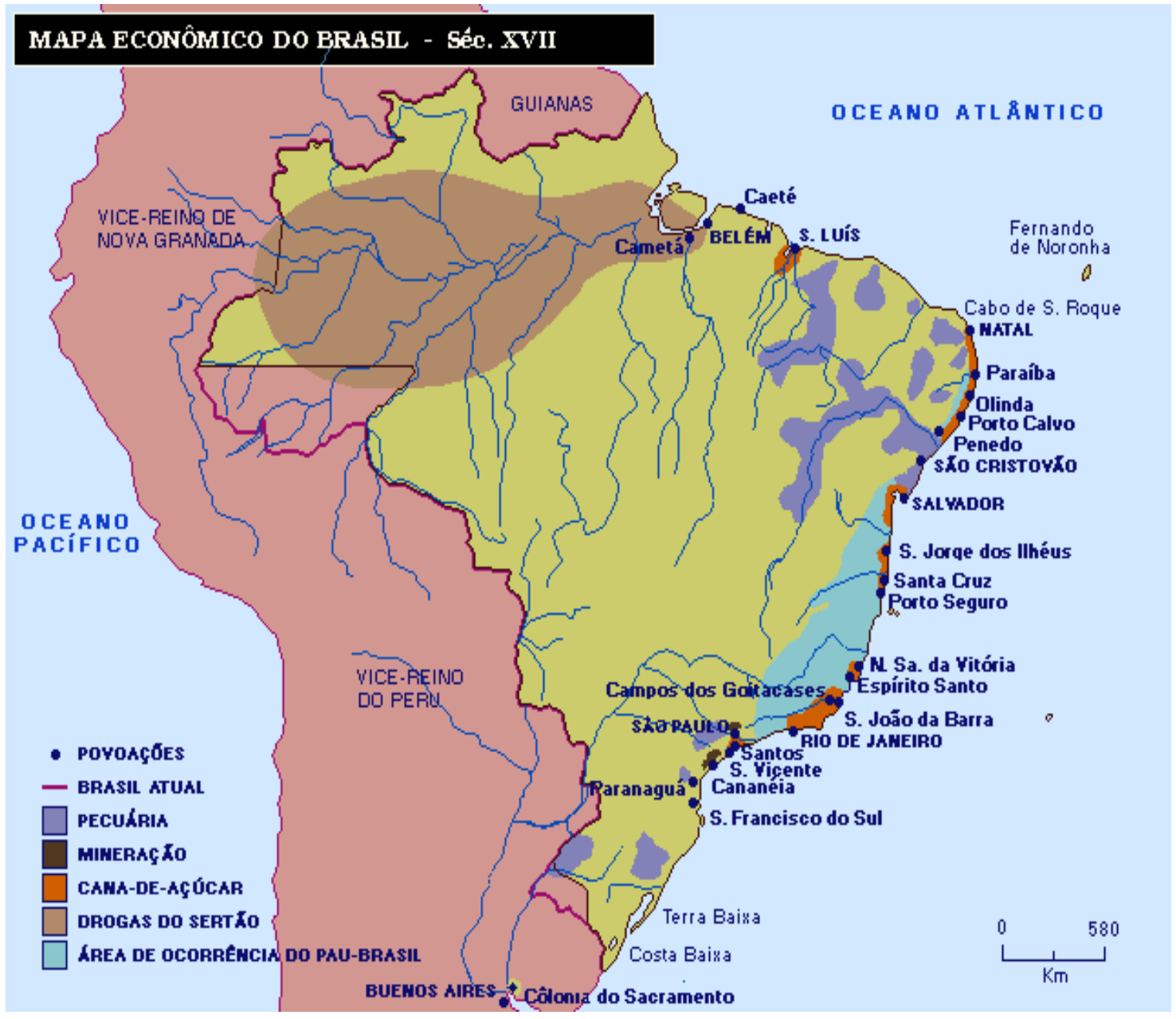

Figura 2.1.1. Atividades econômicas no Brasil no século XVII. Fonte: http://cafehistoria.ning.com/photo/mapa-historico-brasil.

Após a década de 1850, destacaram-se novos ramos fabris, como os do couro, dos calçados, das malas, da chapelaria, das mobílias e das tipografias, espalhados por todo o País, os quais dependiam fortemente de certas matérias-primas e maquinarias importadas. Ainda se pode acrescentar a existência de um grande número de pequenas fábricas de fundo de quintal, nas quais empregados e patrões trabalhavam lado a lado com reduzido número de máquinas, como ocorria nos ramos mecânicos, na produção de massas alimentícias, de sabão etc. Entretanto, em 1869, foi registrado o uso de máquina a vapor, pela primeira vez, numa fábrica de tecidos situada em Itu (SP) (MENDONÇA, 2004, p. 16).

Boa parte das indústrias brasileiras, até os anos finais do século XIX, concentrava-se no Estado do Rio de Janeiro, suplantado, pouco a pouco, por São Paulo. Quanto ao resto do País, outros centros começam a despontar, embora em menor escala, 
como o núcleo industrial de Salvador (BA), o de Recife (PE) e o de Blumenau (SC), todos eles especializados no setor têxtil. Em Porto Alegre (RS), as indústrias concentraram-se na produção de charutos, conservas, embutidos e curtumes, com preponderância dos estabelecimentos de pequeno porte (MENDONÇA, 2004; ROCHE, 1969; PRADO JR., 1971).

Muitas unidades fabris, por conveniência denominadas de industriais, surgidas antes da implantação da grande indústria, nas décadas de 1880 e 1890 não passam de pequenos empreendimentos. Em sua maioria consistem em estabelecimentos nos quais o trabalho era desempenhado por grande número de operários, mas com técnica ainda incipiente, sendo pequena a quantia de capitais investidos e precária a força motriz predominante. As fábricas de proporções menores, sobretudo, por falta de proteção tarifária e pelos obstáculos naturais para se configurar um mercado interno efetivo, sofriam a brutal concorrência estrangeira, que atrapalhava ainda mais seu crescimento.

Medidas protecionistas foram tomadas adiante pelo governo imperial, motivadas pela excessiva presença de mercadorias inglesas e de outros países europeus, bem como dos Estados Unidos. Com isso houve aumento das tarifas na década de 1840. Embora seu objetivo principal fosse ampliar a receita do Governo, essa medida exerceu alguns efeitos colaterais que resultaram na abertura de várias empresas têxteis. O Estado também exercia isenção de taxas para as importações de matérias-primas e maquinários utilizados por empresas nacionais, que depois também ficaram isentas de pagar impostos (BAER, 1983, 1996).

Em resumo, em boa parte do século XIX o Brasil contava com técnicas rudimentares e mão-de-obra pouco especializada. As manufaturas não tinham condições de competir com os produtos ingleses, que eram de melhor qualidade e de preços mais baixos que os produtos aqui fabricados. O atraso do País em relação à Europa e aos Estados Unidos é resultante ora da posição privilegiada ocupada pela Inglaterra que fornecia bens manufaturados, ora da falta de uma representação comercial essencialmente nacional. Outros obstáculos se impunham à atividade industrial brasileira, como o modo de produção escravista e o insuficiente crescimento do número de consumidores ativos dificultado pela dispersão da população, predominantemente rural (MENDONÇA, 2004; BAER, 1996; CASTRO, 1972; PRADO Jr. 1971). Dessa 
forma, com o baixo grau de urbanização, não foi possível criar um mercado interno consistente que tipificasse uma industrialização efetiva ${ }^{7}$.

\subsection{MOLDES DE UMA INDÚSTRIA NACIONAL}

Um fator considerável para a expansão industrial é a abolição da escravatura em 1888 e, um ano depois, a proclamação da república. A abolição levou à desorganização de algumas tradicionais regiões agrícolas, provocando o êxodo de um vasto número de fazendeiros para as cidades, onde passaram a se dedicar à indústria e ao comércio. Por outro lado, ao possibilitar a vinda de contingentes de ex-escravos do interior para as cidades, principalmente para a Capital Federal, a abolição aumentou o número de trabalhadores pouco qualificados para os diversos trabalhos urbanos disponíveis.

Pela abundância de trabalhadores que decorre outra característica da industrialização brasileira em sua etapa inicial: o predomínio das indústrias de bens de consumo corrente voltados para a maioria da população, tais como tecidos, vestuários, alimentos etc. É sabido que os estabelecimentos fabris se concentravam nos centros urbanos maiores, e os operários das fábricas e os demais trabalhadores urbanos formavam o principal mercado consumidor desse tipo de produto. Tais indústrias adequavam-se à disponibilidade de capitais e de tecnologias então existentes no País (MENDONÇA, 2004, p. 23).

Nos primeiros anos da República as exportações de café, borracha e cacau se expandiram, trazendo prosperidade a algumas das novas regiões de produção agrícola, especialmente o Estado de São Paulo. A prosperidade e o afluxo de imigrantes europeus proporcionaram considerável mercado para os bens industrializados, tanto os importados como os fabricados no Brasil. Ou seja, os últimos anos do século XIX justificavam cada vez mais uma escola de pensamento favorável à industrialização, uma

\footnotetext{
${ }^{7}$ O brasilianista Werner Baer diverge da opinião consensual dos estudiosos brasileiros sobre a fase préindustrial do País, com base nas assertivas de seus colegas Nathaniel Leff, 1969 e Waren Dean, 1969 , para os quais no Brasil houve uma industrialização substancial anterior às duas guerras e à Depressão da década de 1930: “A industrialização brasileira como um todo, parece ter-se realizado sob condições semelhantes às que ocorreram em outras regiões de colonização recente, ou seja, em conjunção com a rápida expansão com o comércio exterior e com forte apoio do governo, sob a forma de proteção tarifária” (LEFF, 1969, apud BAER, 1983).
} 
vez que o número de indústrias no País aumentou de 639, em 1889, para 1088, em 1895 (BAER, 1983, p.11).

No início do século XX, a distribuição das atividades industriais ainda mantém a estrutura das décadas anteriores: a indústria têxtil e a de alimentação compreendem a parte substancial do conjunto. Outra característica a assinalar é sua grande dispersão pelo território brasileiro. Apenas as indústrias de fiação e tecelagem de algodão, lã e juta apresentam certa concentração. Nas demais, encontra-se excepcionalmente algum grande estabelecimento; o resto corresponde às pequenas unidades que não passam de modestas oficinas com reduzido número de operários e inversão insignificante de capital. Baseado no censo geral e completo das indústrias brasileiras de 1907, a distribuição geográfica industrial configurava-se da seguinte forma: $33 \%$ da produção cabiam ao Distrito Federal (RJ); $16 \%$ a São Paulo e $15 \%$ ao Rio Grande do Sul, e nenhum outro estado alcançara 5\% (PRADO JR., 1971, p. 261).

O número de estabelecimentos industriais, de pouco mais de 200 em 1881, ascende no último ano da monarquia, em 1889, para mais de 600. O capital investido sobe 400.000 contos (cerca de 25 milhões de libras), sendo que $60 \%$ na indústria têxtil, $15 \%$ na de alimentação, $10 \%$ na de produtos químicos e análogos, $4 \%$ na indústria de madeira, $3,1 \%$ na de vestuário e objetos de toucador e 3\% na metalurgia. Esta fase de progresso na indústria prolongar-se-á na no período republicano (PRADO JR, p. 259).

A crítica mais contundente voltada aos instrumentos de políticas governamentais, tais como as tarifas, grosso modo não foram tão eficientes para provocar a substituição doméstica de importações. O primeiro surto de industrialização no Brasil foi fortuito e ocasionalmente reforçado por forças exógenas. Os estímulos externos, enquanto desviavam a demanda em favor da indústria doméstica, não afetavam a oferta de maneira igualmente construtiva (FISHLOW, 1977, p. 10). Como consequência, as altas taxas de crescimento foram obtidas sem as altas taxas de aumento de produtividade e de transferências tecnológicas correspondentes.

\subsubsection{Componentes sociais}

Antes de abordar-se a questão da cultura cafeeira e suas implicações no surgimento da indústria nacional, como se fará logo adiante, é conveniente lembrar que o processo de industrialização também se deu a partir da organização da sociedade, 
polarizada entre os proprietários latifundiários que constituíam o grupo de pessoas dominante no século XIX, com grande poder para aquisição de bens importados e, na outra ponta, o trabalhador (escravo) com baixo ou nenhum poder de compra e de produtividade. Tal situação muda com a chegada dos contingentes de imigrantes europeus.

Como a sociedade brasileira tradicional do século XIX não possuía condições internas efetivas para promover o crescimento industrial, os imigrantes europeus que chegaram ao Brasil se constituíram no elemento que faltava: inseriram-se como grupo de pessoas de considerável capacidade de produção e consumo, que cresceu mais e modificou nitidamente o conjunto da vida brasileira, provocando o ingresso do País no capitalismo do tipo europeu. Dessa forma, o imigrante desempenhou um papel significativo na industrialização brasileira, tendo em vista que esse processo ocorreu mediante iniciativas particulares e governamentais (MAMIGONIAN, 2005; PRADO JR., 1971).

Os latifundiários que compunham a categoria social dominante da época consumiam em sua maioria produtos importados; portanto, não estimulavam o crescimento da indústria nacional. No outro extremo estavam os escravos com baixíssimo poder de compra. Substituindo os escravos, os imigrantes apresentavam hábitos econômicos equilibrados, nível de vida bem mais elevado que o dos escravos e a ambição por independência econômica, quadro esse que estimulou o surgimento de inúmeras indústrias e formou um mercado consumidor para a industrial brasileira nascente (MAMIGONIAN, 2005).

Os ricos cafeicultores paulistas fundaram a Sociedade Promotora de Imigração, que recebeu do governo provincial a incumbência de organizar a introdução dos imigrantes. O sistema arquitetado era muito conveniente para os latifundiários, pois eles deveriam ser arregimentados na Europa, sobretudo Itália, Portugal e Espanha, países cujas transformações no campo haviam dado origem a um contingente de trabalhadores sem terra e submetidos à absoluta miséria (LUCA, 2001, p. 16).

Após atravessar o Atlântico, os que se destinavam ao Brasil aportavam em Santos, no litoral paulista, e eram transportados para a Hospedaria dos Imigrantes ${ }^{8}$, em

\footnotetext{
${ }^{8}$ Construída entre os anos de 1886 e 1888, a antiga "Hospedaria de Imigrantes do Brás" foi um dos maiores centros de recepção de estrangeiros já existentes no Brasil. Por suas dependências, passaram mais de dois milhões de pessoas entre os anos de 1887 e 1978. As informações aqui apresentadas registram a parte mais significativa deste fluxo migratório, sendo a transcrição dos registros dos livros
} 
um enorme prédio no bairro paulistano do Brás, inaugurado em 1887, com capacidade de abrigar até três mil pessoas. Nele permaneciam por no máximo oito dias, após o que assinavam ali mesmo contratos, em geral com duração de um ano, para trabalharem nos cafezais. Os custos, desde o embarque da Europa até sua instalação no Brasil, corriam por conta do governo paulista. Desse modo, no ato de chegada à porteira da fazenda onde iria trabalhar, o imigrante não recebia qualquer centavo do proprietário dessa fazenda (LUCA, 2001). Desiludidos com as péssimas condições que encontravam nas fazendas, tão logo cumprido o contrato de um ano, os imigrantes saíam à procura de melhores oportunidades, em centros urbanos maiores. Não obstante, esses centros urbanos formaram um estoque de trabalhadores para a atividade industrial emergente. Somente no período entre 1891 e 1910, quase 1.800.000 deles vieram para o Brasil, integrando-se a uma população de um montante de mais de 22.000 .000 de habitantes (MENDONÇA, 2004, p. 22).

\subsubsection{Economia do café}

Uma significativa parcela de estudiosos da economia brasileira argumenta que o maior e mais duradouro impulso ao desenvolvimento industrial do País vinha da própria atividade agrícola, mais precisamente, de uma atividade de exportação, que se expandia, inicialmente nas Províncias do Rio de Janeiro, Espírito Santo e Minas Gerais, a cultura cafeeira.

À medida que a fertilidade do solo do Vale do Paraíba do Sul se esgota, por volta da década de 1880, a produção de café migra mais para o Sul, em direção a São Paulo e depois ao oeste dessa província (BAER, 1883; FURTADO, 2010; ABREU 1999). A extraordinária expansão da lavoura cafeeira na Província de São Paulo, ocorrida a partir de 1870, justificada pela presença de terras férteis na região do oeste paulista, aliada à alta do preço do café no exterior, determinou a corrida ao interior do

\footnotetext{
de matrícula desta hospedaria para os anos de 1887 até 1958. Com o fechamento desta instituição para reformas, o Arquivo Público do Estado de São Paulo ficou com a custódia temporária de seu acervo arquivístico, sendo também o responsável pela emissão das "Certidões de Desembarque" elaboradas com base na documentação em questão (Governo do Estado de São Paulo). Link de acesso: http://www.arquivoestado.sp.gov.br/livros_estrangeiros.php
} 
Estado, onde extensas áreas de matas nativas deram lugar ao cinturão de café (BAER, 1995, pp. 34-35).

O capital oriundo do exterior participou em setores chaves da economia, como na construção de mais ferrovias e bancos de fomento, uma vez que estes financiavam os cafeicultores que investiam mais e mais na formação ou ampliação de suas fazendas. Esse capital passou a controlar uma atividade vital para a expansão cafeeira: o transporte ferroviário que promoveu a penetração para o interior e o escoamento das safras aos portos de embarque no litoral paulista, em Santos. Com recurso estrangeiro de ingleses foram sendo instaladas progressivamente estradas ferroviárias em São Paulo, vindo a tornar essa província tão eficiente na produção cafeeira quanto a do Rio de Janeiro. A maioria das ferrovias foi construída por empresas inglesas (MENDONÇA, 2004; ABREU, 1999; BAER, 1983).

As vendas de café para o exterior consistiram em crescimento quase em todo o século XIX e, na última parte desse século, a economia do produto transferiu-se para São Paulo, de modo que o centro econômico mudou gradualmente para essa região. $\mathrm{O}$ café propiciou, sobretudo, a multiplicação de serviços do setor terciário na economia da Região Sudeste. Por conseguinte, ampliou consideravelmente a concentração da população nas cidades, o que não deixava de ser um forte estímulo à multiplicação da indústria. Daí que a indústria não só dependeu da diversificação desse complexo agrário exportador, como dele se beneficiou em vários aspectos essenciais (BAER, 1983, 1995; ABREU, 1999; MENDONÇA 2004).

Em suas análises da desenvoltura econômica brasileira Celso Furtado deixa claro que havia diferenciações entre os emergentes proprietários das lavouras cafeeiras e os anteriores fazendeiros de cana-de-açúcar. Por um lado, ele argumenta que no apogeu do ciclo do açúcar o comércio era monopólio dos portugueses e, consequentemente, os proprietários de fazendas de cana-de-açúcar, separados pelo comércio, nunca se transformaram em empreendedores progressistas. Por outro lado, os produtores de café estavam mais ligados ao objetivo comercial de seu setor, além de estarem mais próximos da capital federal do que os produtores de cana-de-açúcar. Desse modo, os cafeicultores, mais do que outros produtores, estavam conscientes da função potencial a ser desempenhada pelo Estado na influência sobre seus interesses econômicos. Isso explica, em parte, o apoio que esse setor obteve do Estado no século XX (BAER, 1995; ABREU, 1999). 
As condições econômicas nas primeiras décadas do século passado estavam amadurecidas para pressionar a sociedade brasileira tanto para superar as dificuldades iniciadas em 1929 como para aprofundar o desenvolvimento industrial do país, cujos principais representantes da classe dominante eram os fazendeiros, os industriais, os comerciantes e os banqueiros. "O Brasil fez parte de um grupo seleto de países que enfrentaram a situação de crise e que enveredaram mais que os outros latinoamericanos, pelos caminhos da industrialização" (CANO, 2002). Ainda que as pressões do processo econômico por mudanças estivessem presentes, foi necessária sua condução, pelo Estado, no governo de Getúlio Vargas.

Em meio aos percalços econômicos vivenciados nos anos finais de 1920 e os anos de 1930, em decorrência da crise cafeeira, pode-se argumentar, com apoio em Celso Furtado (2010), que a "política de proteção ao café" foi um tipo de programa anticíclico $^{9}$ keynesiano $^{10}$ financiado pela expansão do crédito. A garantia de preços mínimos possibilitou manter o nível de emprego do setor cafeeiro e, indiretamente, de setores internos relacionados. Como a produção de café continuava a crescer, foi possível fazer que a renda do setor caísse menos que seus preços (BAER, 1995, p. 53). O Estado teve uma ação vigorosa para sustentar essa economia cafeeira (FURTADO 2010; CANO, 2002).

A depressão que se produzia nos anos de 1930, causou impactos negativos sobre as exportações brasileiras, cujo valor sofreu uma queda substancial de US\$ 445,9 milhões em 1929 para US\$ 180,6 milhões em 1932. Em 1931, o preço do café atingiu um terço do preço médio que alcançara entre 1925-29 e as relações de troca do País

\footnotetext{
9 Uma política econômica anticíclica consiste no conjunto de ações governamentais voltadas a impedir, sobrepujar, ou minimizar os efeitos do ciclo econômico.

${ }^{10}$ Segundo a escola keynesiana, o significado do programa anticíclico é de que o déficit público é o principal instrumento de política econômica para amenizar os efeitos do ciclo. Déficit público ocorre quando o valor das despesas de um governo é maior que as suas receitas. Assim, durante a recessão, o governo deve intervir, reduzindo tributos, promovendo a expansão do crédito e o aumento dos gastos, realizando investimentos capazes de estimular a economia. Desta forma, durante a recessão, o déficit público deve se expandir de modo a restabelecer o equilíbrio econômico. O inverso deve ocorrer durante a fase ascendente do ciclo: nos períodos de prosperidade, o Estado deve aumentar a tributação, constituindo um superávit para pagar suas dívidas e formar um fundo de reserva que possa ser utilizado durante os períodos de recessão.
} 
haviam caído em $50 \%$. A entrada de capitais externos cessou quase por completo em 1932 em virtude da crise econômica generalizada no País (ABREU, 1999; BAER, 1983, 1996).

Relata-se que a queda das exportações brasileiras e a grande quantidade de divisas necessárias ao financiamento da dívida externa do Brasil, sem contar as remessas de lucros de entidades privadas, obrigou o governo a tomar medidas severas. Por exemplo, em agosto de 1931, o Governo suspende parte dos pagamentos da dívida externa e inicia negociações para chegar a um acordo sobre sua consolidação (BAER, 1996, p. 50).

Dada a crise dos anos de 1930, a restrição das importações e a contínua demanda interna que resultou da receita gerada pelo programa de apoio ao café causaram escassez de bens manufaturados e consequente aumento em seus preços relativos, o que agiu como indutor para uma arrancada na produção industrial. Como ocorreu na primeira Guerra Mundial (1914-1919), o crescimento da produção industrial na primeira metade dos anos de 1930 baseou-se na utilização completa da capacidade existente, grande parte da qual havia sido subutilizada e formada na década anterior. Na segunda metade dessa década, o crescimento da produção industrial foi acompanhado pela expansão da capacidade e pelos investimentos do exterior (BAER, 1996, p. 53).

Quanto aos investimentos estrangeiros, no período da Depressão, houve redução em termos absolutos do capital direto do exterior em operação no Brasil, algo que estava associado não apenas às dificuldades gerais pelas quais passava a economia internacional, mas também à seriedade da crise cambial enfrentada pelo Brasil durante todo o período. É muito mais provável que tal situação tenha afetado o investimento de outros países, que não o britânico e o norte-americano. Entre 1936 e 1940, ocorreu um grande aumento do investimento norte-americano também (Tabela 2.2.2.1) (ABREU, 1999, p. 260).

Na primeira metade da década de trinta, não se definia uma política brasileira em relação ao investimento direto estrangeiro, apesar dos muitos problemas enfrentados pelas empresas que tentavam remeter lucros e juros ao exterior, sobretudo antes de 1934 (ABREU,1999, p. 262). A Constituição de 1934 e os códigos de Minas e das Águas incluíam disposições mais rígidas sobre investimento estrangeiro: reservavam a brasileiros as concessões de mineração e de exploração de recursos hídricos, e as companhias de seguros e bancos comerciais estrangeiros deveriam ser progressivamente nacionalizadas. 
Tabela 2.2.2.1. Investimento estrangeiro direto, em milhões de libras, em anos selecionados, 1930-1945.

\begin{tabular}{|l|c|c|c|c|c|}
\hline & 1930 & 1936 & 1940 & 1943 & 1945 \\
\hline Reino Unido $^{11}$ & 119 & 103 & 98 & 92 & 85 \\
\hline Ferrovias & 49 & 38 & 36 & 33 & 31 \\
\hline Outros & 70 & 65 & 62 & 59 & 54 \\
\hline EUA $^{12}$ & 44 & 39 & 60 & 58 & 81 \\
\hline Indústria & 10 & 10 & 17 & 16 & 32 \\
\hline Petróleo & 5 & 7 & 8 & 7 & 11 \\
\hline Distribuição & 4 & 3 & 4 & 7 & 0 \\
\hline Serviços Públicos & 22 & 17 & 28 & 22 & 31 \\
\hline Outros & 3 & 2 & 3 & 6 & 7 \\
\hline Outros Países & 80 & $\ldots .$. & 24 & $\ldots \ldots$. & $\ldots \ldots$ \\
\hline Total & 243 & $\ldots \ldots$ & 172 & $\ldots \ldots$. & $\ldots \ldots$ \\
\hline
\end{tabular}

Fonte: Abreu, 1999.

A Constituição de 1937 incorporou essas regras de maneira ainda mais radical, propondo que as empresas de mineração e indústrias "essenciais" fossem nacionalizadas. Um sistema de quotas para imigração também foi instituído, bem como uma legislação regulamentando a propriedade e a operação de companhias de navegações brasileiras e a proporção de empregados nacionais em cada empresa operando no Brasil. No entanto, a legislação federal mais severa quanto à instalação de empresas estrangeiras foi sendo relaxada por legislação subsequente e também por interpretações mais flexíveis (ABREU, 1999, p. 262-263).

\footnotetext{
${ }^{11}$ Para 1936-45, estimativas do South American Journal foram utilizadas, pois são comparáveis com a estimativa para 1930.

${ }^{12}$ Investimento total em 1930 distribuído setorialmente na mesma proporção de 1929.

${ }^{13}$ Não existem informações de investimentos de outros países em 1936, 1943 e 1945.

14 Essas estimativas devem ser consideradas com reservas, pois os dados sobre investimentos estrangeiros, à exceção dos britânicos e norte-americanos, são notoriamente ineficientes, inclusive pelas dificuldades relativas à definição de nacionalidade dos controladores da maior parte das empresas de propriedade original de italianos, alemães e portugueses que operavam no Brasil.
} 
As dificuldades com a legislação nacionalista invariavelmente envolveriam mais empresas de serviços públicos e não as empresas industriais ou comerciais. No decorrer da década de 1930, atritos frequentes, sobretudo decorrentes da nacionalização das empresas de serviços públicos, dificultaram as relações externas do Brasil, especialmente com o Reino Unido. Ainda que as regras para bancos, seguros e navegação encontravam pouca oposição, houve um descontentamento com o excessivo nacionalismo da legislação para a mineração, e especialmente para hidroeletricidade. É mais provável que tenha sido no ramo da mineração que a legislação nacionalista tenha impedido um desenvolvimento mais significativo do investimento estrangeiro. As leis, de modo geral, devem ter agido como desestímulo a que o investimento estrangeiro no Brasil tivesse sido maior do que de fato foi, mas também é verdade que o investimento dos EUA cresceu consideravelmente entre 1936 e 1945 (ABREU, 1999, pp. 262-263).

\subsubsection{Base agrícola}

A partir de uma base agrícola são identificadas quatro interpretações principais a respeito do desenvolvimento industrial brasileiro: 1) a teoria dos choques adversos; 2) a ótica da industrialização liderada pela expansão das exportações; 3) a interpretação baseada no desenvolvimento do capitalismo no Brasil, ou simplesmente "capitalismo tardio"; e 4) a ótica da industrialização intencionalmente promovida por políticas de governo (SUZIGAN, 2000, p. 23).

Na teoria dos choques adversos, a industrialização surgiu como uma resposta às dificuldades impostas às importações pelos impactos produzidos pela Primeira Guerra Mundial, a Grande Depressão da década de 1930 e a Segunda Guerra Mundial (SUZIGAN, 2000, p. 23).

A ótica da industrialização liderada pela expansão das exportações, por outro lado, pressupõe a existência de uma relação linear entre a expansão do setor exportador (principalmente do café) e a industrialização. Conforme essa interpretação, o crescimento industrial ocorrido durante períodos de expansão das exportações era seguidamente interrompido pelas crises no setor exportador, como o advento das guerras e a depressão da década de 1930.

A teoria qualificada como "capitalismo tardio" (MELLO, 2009; CANO, 1977; TAVARES, 1973), na sua essência, é uma revisão da doutrina cepalina tradicional. Mesmo reconhecendo a importância da doutrina para entender as peculiaridades do 
desenvolvimento latino-americano e aceitando o postulado de que o desenvolvimento industrial dessa região é periférico, a ótica do capitalismo tardio refuta o caráter reflexo atribuído às economias latino-americanas pela doutrina da Cepal (SUZIGAN, 2000, p.24).

A interpretação do "capitalismo tardio" propõe ainda que o crescimento industrial se deu como parte do processo de desenvolvimento do capitalismo no Brasil. De acordo com esse pensamento, a acumulação de capital industrial ocorreu juntamente com a acumulação de capital no setor exportador nos períodos de expansão das exportações. Essa interpretação poderia ser confundida como uma "versão dialética" da industrialização liderada pela expansão das exportações; contudo, ela difere da última ao propor uma relação não linear (ou contraditória) entre o setor exportador e a indústria de transformação. Ou seja, ao mesmo tempo em que a expansão da economia cafeeira estimula o crescimento industrial, também impõe limites a esse crescimento.

Finalmente, a interpretação centrada no papel das políticas deliberadas do Governo para promover o desenvolvimento industrial é sobremaneira essencial, especialmente devido à proteção aduaneira e à concessão de incentivos e de subsídios à indústria (SUZIGAN, 2000, p. 24). Outros estudiosos dizem que tais políticas só foram implementadas depois da década de 1950, presumindo com isso que o papel do Estado na promoção do desenvolvimento industrial, no período anterior aos anos de 1930, foi em realidade pouco significativo (CANO, 2002).

Suzigan (2000, p. 41) esclarece que existe consenso de que a política governamental, conforme definida por Hirschman, não foi implementada no Brasil antes da década de 1950. Segundo a ótica de Hirschman (1968, p. 1-31) "uma política intencional de desenvolvimento é aquela levada a efeito não apenas por meio de proteção aduaneira, mas através de uma ampla gama de instrumentos de política fiscal e creditícia, através de pressões sobre as firmas importadoras estrangeiras para que estabeleçam operações industriais, bem como através da ação direta: o estabelecimento de empresas industriais estatais, ou, crescentemente, de companhia ou bancos de desenvolvimento que são encarregados de promover empreendimentos específicos”.

A intenção declarada da corrente de pensamento anterior é a de contestar a afirmação, normalmente encontrada na historiografia brasileira, de que o papel do Estado na promoção do desenvolvimento industrial anterior a 1930 foi mínimo ou não significativo. Suzigan (2000, p. 41), argumenta que comumente o senso comum diz o contrário: o Estado desempenhou um papel positivo, primeiramente por uma proteção 
alfandegária deliberada e, em segundo lugar, por meio da concessão de incentivos e subsídios a indústrias específicas.

Salienta-se ainda que no período anterior à Primeira Guerra Mundial praticamente nenhuma assistência direta foi concedida pelo governo à indústria de transformação, exceto à indústria do açúcar e, das ocasionais isenções de direitos sobre maquinarias importada e outras formas indiretas de apoio do governo, como, por exemplo, o desenvolvimento da malha de transportes e de infraestrutura (Suzigan, 2000, p.47). A partir da Primeira Guerra, o Estado começou a estimular intencionalmente o desenvolvimento de algumas indústrias específicas, mas não o desenvolvimento industrial de modo integral. O que se enfatiza, no entanto, é que os incentivos e subsídios concedidos não eram sistemáticos e nem sempre foram eficazes.

\subsection{INDÚSTRIA E PLANEJAMENTO}

A partir dos anos de 1930, minorada a competição estrangeira, a substituição de importações leva a um avanço progressivo da manufatura no País. A industrialização substitutiva conduzida inicialmente pela demanda de ex-importadores, integrantes de classes com altas e médias rendas, avança e se consolida muito acima da maior parte da população. Inacessíveis às massas brasileiras, as novas formas de consumo ficam ao alcance das classes mais elevadas que encontram no exemplo americano um permanente estímulo à diversificação e melhoria qualitativa dos produtos demandados. A concentração de renda em estratos de alto poder aquisitivo passa a reforçar um gênero de mercado: o de bens de consumo duráveis do tipo moderno (CASTRO, 1972, pp. 125127).

À medida que a crise da produção cafeeira se agrava, parcelas crescentes de capitais gerados na lavoura e também originados de outras fontes são deslocadas sistematicamente para investimentos na atividade industrial, que apresenta perspectivas promissoras. A crise cafeeira pressiona no sentido de se criarem novas fontes geradoras de riquezas, e a indústria é tida como setor preferido e definido pelos que desejam a modernização do País, retirando-o do atraso colonial em que ainda se encontrava.

O impulso recebido pelas atividades industriais, após os anos de 1930, não foi arrebatador e capaz de modificar drasticamente a estrutura da sociedade brasileira. Entre 1920 e 1950 houve algumas mudanças na estrutura da produção industrial, embora não 
tão profundas (Tabela 2.3.1). As indústrias têxteis e de produtos alimentícios continuam sendo as de maior predominância no período, mas os setores metalúrgico, mecânico, químico e farmacêutico aumentam bastante seu peso relativo na estrutura industrial, embora sem alterar basicamente o quadro geral (BAER, 1983, p. 21).

Tabela 2.3.1. Distribuição por setores da atividade industrial.

(Percentagens do valor total adicionado)

\begin{tabular}{|c|c|c|c|}
\hline Indústrias & 1920 & 1940 & 1950 \\
\hline Minerais & 4,7 & 5,3 & 7,4 \\
\hline Metalúrgica & 4,3 & 7,7 & 7,4 \\
\hline Mecânica & 2,0 & 5,8 & 2,2 \\
\hline Mat. Elétrico & - & & 1,7 \\
\hline Mat. de Transporte & - & & 2,3 \\
\hline Madeira & 5,8 & 5,1 & 3,4 \\
\hline Mobiliária & 2,0 & & 2,2 \\
\hline Papel & 1,5 & 1,4 & 2,1 \\
\hline Art. de Borracha & 0,2 & 0,7 & 2,1 \\
\hline Couro & 2,4 & 1,7 & 1,3 \\
\hline Quím. e Farmácia & 6,0 & 10,4 & 9,4 \\
\hline Têxtil & 28,6 & 22,7 & 20,1 \\
\hline Vestuário, Calçado & 8,6 & 4,9 & 4,3 \\
\hline Alimentares & 22,2 & 22,9 & 19,6 \\
\hline Bebidas & 5,9 & 4,5 & 4,3 \\
\hline Fumo & 3,9 & 2,2 & 1,6 \\
\hline Editorial Gráfico & - & 3,6 & 4,2 \\
\hline \multirow[t]{2}{*}{ Diversos } & 1,9 & 1,5 & 4,4 \\
\hline & 100 & 100 & 100 \\
\hline
\end{tabular}

Fonte: Censos industriais de 1920, 1940 e 1950 (BAER, 1983, p. 13).

A Segunda Guerra Mundial significou para o Brasil um estímulo à sua posterior industrialização quando gerou a estagnação e mesmo o declínio no quantum das importações e das exportações. Este foi o principal estímulo à elevação do índice relativo à indústria, que constituía o setor de crescimento mais dinâmico na formação do 
produto interno real naquele período. Em relação às importações, especialmente no que se refere aos bens de capital e outros produtos manufaturados, a redução foi consequência da interrupção dos suprimentos ocasionada não só pela escassez de produtos disponíveis nas fontes euro-americanas, como também pelas dificuldades de transporte marítimo. E relativo às exportações, embora diminuísse sua quantidade, seu valor aumentou consideravelmente de modo que se acumulou durante a II Guerra grande reserva de divisas (BAER, 1983, p. 21).

A indústria foi beneficiada pela II Guerra através do expressivo desaparecimento da competição estrangeira, particularmente pela carência total de produtos cujo suprimento provinha exaustivamente do exterior. Além de passarem a ter o mercado interno ao seu inteiro dispor, muitas das indústrias brasileiras viram-se chamadas a preencher o vácuo deixado em outros países pela perda de contato com seus fornecedores tradicionais de produtos manufaturados. Assim, a exportação de determinados artigos nacionais tornou-se pela primeira vez, um item na pauta exportadora do Brasil. A expansão mais notada ocorreu na indústria têxtil que passou a exportar para outros países latino-americanos e africanos. As indústrias metalúrgicas e de máquinas se expandiram em São Paulo e, após a II Guerra, verifica-se a instalação da usina siderúrgica governamental de Volta Redonda abrindo caminho para novas e imponentes etapas no desenvolvimento industrial do Brasil (BAER, 1983, p. 23).

Devido às fragilidades e inconstâncias da política econômica brasileira, entre as décadas de 1930 e 1940, aumentaram os estudos sobre a estrutura econômica do Brasil, com propósito de nortear o desenvolvimento do País. Um dos primeiros estudos é o “Relatório Niemeyer”, preparado por Sir Otto Niemeyer e publicado em 1931 (ABREU, 1999; BAER, 1983).

A missão de Niemeyer ao Brasil, em 1931, foi a mais importante tentativa de influenciar a formulação da política econômica brasileira no início da década de 1930. Essa missão foi importante ainda como tentativa de restauração da influência britânica no Brasil, que vinha declinando desde a Primeira Guerra Mundial (ABREU, 1999, p. 80). Niemeyer foi encarregado de aconselhar o governo brasileiro sobre as reformas que se faziam necessárias para assegurar a manutenção do equilíbrio do orçamento, a estabilização do câmbio, a reforma monetária, a reestruturação do Banco do Brasil como um banco central ortodoxo e independente e a limitação do endividamento direto e indireto dos governos federal e estaduais (ABREU, 1999, p. 83). 
Niemeyer foi o primeiro a declarar, publicamente, aquilo que muitos brasileiros já haviam percebido: que a principal deficiência do País consiste em apoiar-se na exportação de apenas um ou dois produtos agrícolas, ou seja, a economia dependia primordialmente de produtos gerados pelo setor primário. Essa é a razão primordial de a crise atingir o Brasil mais abruptamente do que em outros países. O relatório, no entanto, foi recebido sem entusiasmo, pois consistia, naquela época, em verdadeira profanação criticar a excessiva dependência do País em relação ao café (BAER, 1983, p. 25).

$\mathrm{Na}$ declaração de Otto Niemeyer, a diversificação da agricultura terminaria por elevar a renda do setor e esse incremento, associado à poupança no intercâmbio externo, forneceria os recursos necessários às inversões industriais. Ademais, na parte restante do relatório ele fez criticas quanto às finanças públicas brasileiras e indicou os métodos para reestruturá-las. O relatório representou a primeira tentativa, da parte das autoridades brasileiras, de examinar a economia do País e prospectar seu crescimento (BAER, 1983, p. 25-26).

Posteriormente, uma nova tentativa de analisar a economia brasileira, recomendar mudanças em sua estrutura e indicar os meios necessários para alcançá-las foi feita pela Missão Cooke ${ }^{15}$. A referida missão estava constituída de técnicos norteamericanos e patrocinada conjuntamente pelo governo brasileiro e estadunidense. A missão visitou o Brasil em 1942 e 1943.

Seu trabalho representou a primeira pesquisa analítica e sistemática feita a respeito da economia brasileira com o objetivo de formular um programa de ação. E pela primeira vez, empreendia-se uma análise econômica do ponto de vista regional dividindo o País em três regiões distintas: Nordeste, Centro-Oeste e Sul, cujas características econômicas diferenciavam-se suficientemente para justificar métodos de análise e programas de desenvolvimento diversos.

A missão analisou vários fatores que representavam obstáculos ao crescimento rápido, e, especialmente, à industrialização. Entre eles o inadequado sistema de transportes, o atrasado método de distribuição do petróleo, a falta de recursos para investimentos industriais, bem como de mecanismos aptos a canalizá-los para essa finalidade, as restrições ao capital estrangeiro, limitações à imigração, baixo nível das

\footnotetext{
15 Ver também Rabelo, F. L. “A presença norte-americana no Brasil e as missões técnicas mistas: um estudo da Missão Cooke (1942)”. http://www.ifcs.ufrj.br/ arshistorica/jornadas/IV_jornada/IV_22.pdf.
} 
instituições para treinamento técnico e sua completa inexistência em determinadas regiões, ausência de produção em grande escala, instalações inadequadas para produção energética etc.

Importante conclusão do Relatório Cooke foi a de que o esforço principal deveria ser concentrado no desenvolvimento do Sul do País (Sudeste/Sul), uma vez que essa porção territorial brasileira reunia melhores condições para o rápido crescimento econômico. Acreditava-se que, a partir daquele núcleo de desenvolvimento, o crescimento difundir-se-ia inevitavelmente pelas outras regiões, devido ao fato de a mesma ter-se beneficiado em maior escala do auge da exportação do café no período mais recente, bem como de ter recebido maior quociente de imigrantes europeus qualificados em fins do século XIX e inícios do século XX (BAER, 1983, p. 26).

Concluiu-se pela possibilidade de se instalarem cada vez mais indústrias na porção Sul do País. Como ponto de partida, deveria ser construído um complexo siderúrgico em escala razoavelmente grande que forneceria a base para a criação da indústria promotora de bens de capital. A missão acreditava que a tarefa básica de industrializar o Brasil deveria ser deixada à iniciativa privada. $\mathrm{O}$ governo nacional dedicar-se-ia ao planejamento industrial geral, além de facilitar o crédito industrial e proporcionar mais ensino técnico (BAER, 1983, p. 27).

A década de 1930 marca o fim de um ciclo e o início de outro na economia brasileira. O período marca o fim da hegemonia agrário-exportadora e o início da predominância da estrutura produtiva de base urbano-industrial, embora essa predominância só se concretize, em termos de participação da indústria na renda interna, no início da implantação do Plano de Metas, quando pela primeira vez a renda do setor industrial superará a da agricultura. Nesse contexto, alguns aspectos passam a desempenhar um papel muito significativo: o primeiro deles faz parte da chamada regulamentação dos fatores no conjunto da economia do Brasil. A esse respeito, a regulamentação das leis de relação entre o trabalho e o capital, implantada pelo Estado, é um dos mais importantes (OLIVEIRA, 1981, pp. 14-16).

O segundo aspecto refere-se à intervenção do Estado na esfera econômica operando na fixação de preços, na distribuição dos ganhos e perdas entre diversos estratos ou grupos de capitalistas, na esfera de produção como fins de subsídio e outras atividades produtivas. Ou seja, o Estado teve o papel de criar as bases para a acumulação capitalista industrial. Assim, assiste-se à emergência e à ampliação das funções do Estado, num período que vai dos anos de 1930, no Governo Vargas até o 
Governo de Juscelino Kubitschek, com seu Plano de Metas em finais dos anos de 1950 (OLIVEIRA, 1981, p. 18). Também nesse ritmo, após esse período, sucessivos planos governamentais são postos em prática entre os anos de 1960 e os anos finais de 2000.

O terceiro aspecto a ganhar saliência refere-se ao papel da agricultura, uma vez que se fazia necessário mantê-la ativa. O sociólogo Francisco de Oliveira argumenta que a agricultura de exportação deveria suprir as necessidades de bens de capital e intermediário de produção externa, antes de simplesmente servir para o pagamento dos bens de consumo. Por outro lado, o sociólogo acredita que a agricultura de produtos destinados ao consumo interno deveria suprir as necessidades das massas urbanas, de forma a não elevar principalmente o custo da alimentação, mas também o custo das matérias-primas, e de forma a não impedir o processo de acumulação urbano-industrial.

A indústria pouco necessitou do mercado rural como consumidor porque ela nunca precisou de incrementos substantivos daquele para se viabilizar. Instalada e promovida ao mesmo tempo que a indústria de automóveis, a indústria de máquinas agrícolas engatinhou até por volta dos anos de 1970, mas não chegou sequer à vigésima parte da primeira. Ou seja, a orientação da indústria foi, principalmente, voltada para os mercados urbanos (OLIVEIRA, 1981, p. 24; CASTRO, 1972, p. 126).

A agricultura, no Brasil, cumpre um papel vital para as virtualidades de expansão do sistema: seja fornecendo os contingentes de força de trabalho, seja fornecendo os alimentos, ela tem uma contribuição importante na compatibilização do processo de acumulação global da economia. De outra parte, ainda que pouco represente como mercado para a indústria, à medida que cresce, a agricultura redefine as condições estruturais daquela, introduzindo novas relações de produção no campo, que torna viável a agricultura comercial de consumo interno e externo pela formação de um proletariado rural. (OLIVEIRA, 1981, p. 25).

A formação do setor industrial é ponto crítico após os anos de 1930. Tratava-se de tornar a empresa industrial a unidade-chave do sistema e de criar ou consolidar novos parâmetros, novos preços de mercado, que canalizassem e orientassem o esforço da acumulação sobre a empresa industrial. Para tanto, o Estado propositalmente intervirá nos pontos e nas formas enunciadas anteriormente. Após os anos de 1930, a interpretação mais usual do ímpeto industrial brasileiro foi reduzida à chamada "substituição de importações".

É sabido que no Brasil começou-se produzir internamente os bens de consumo não duráveis destinados, sobretudo, ao consumo da maioria da população na primeira 
etapa de industrialização. O processo industrial na segunda etapa orientou-se pela produção dos bens de consumo duráveis, intermediários e de capital. Essa etapa de expansão industrial se deve graças à redefinição das relações trabalho-capital, à enorme ampliação do exército industrial de reserva, ao aumento da taxa de exploração, às velocidades diferenciais de crescimento de salários e produtividade que reforçaram a acumulação. Nesse sentido Oliveira salienta que "foram as necessidades da acumulação e não as de consumo que orientaram o processo de industrialização: a "substituição de importações" é apenas a forma dada pela forte desvalorização da moeda local, a condição necessária, porém não suficiente" (OLIVEIRA, 1981, p. 27-28).

É possível perceber que a orientação pela produção industrial por bens duráveis, intermediários e de capital decorreu mais das necessidades de produção/acumulação que do consumo: este é privilegiado sempre no nível da ideologia "desenvolvimentista" que forneceu as bases para o Plano de Metas posteriormente aplicado por JK. Do ponto de vista da acumulação, essa produção pode realizar-se porque a redefinição das relações trabalho-capital deu lugar à concentração de renda que torna consumíveis os produtos e por sua vez reforça a acumulação, dado que a alta produtividade dos novos ramos em comparação com o crescimento dos salários dá um "salto de qualidade", reforçando a tendência à concentração da renda.

Tendo como demanda as camadas populacionais mais ricas em uma distribuição de renda muito desproporcional, a produção nacional de bens de consumo duráveis, dos quais o automóvel era o bem mais representativo, encontra mercado e realiza sua função de acumulação tornando as unidades e os ramos fabris a ela dedicados as unidadeschave do sistema: essas não apenas estão entre as mais rentáveis e mais promissoras do setor industrial, como orientam o perfil da estrutura produtiva (OLIVEIRA, 1981, pp. 28-29).

A concentração geográfica da produção industrial foi em decorrência das políticas praticadas em defesa do segmento econômico dominante, a burguesia cafeeira, concentrada nos estados do Sudeste do País. Durante todo o processo, os investimentos que se transferiram para o setor industrial pouco partiram da iniciativa própria dos industriais. A industrialização do Brasil no período ocorreu de forma significativa, mas não se deu de forma autônoma num processo gradual. Deu-se mediante a proteção do governo em favor da burguesia paulista cafeeira, o que privilegiou os investimentos no setor industrial de São Paulo em detrimento do resto da nação (PEREIRA; ARENDT, 2003). 
A intervenção do Estado na esfera econômica operando na regulamentação de fatores como no rumo da industrialização se processa num período que vai dos anos de 1930 até a década de 1950 e, posteriormente, nos Governos Militares, entre as décadas de 1960 até meados dos anos de 1980. Na administração pública, muitos foram os governantes que buscaram soluções para promover o desenvolvimento que integrasse grande parte do território nacional a partir dos anos de 1930, porque nesse período as lideranças do Brasil se posicionavam com forte conotação nacionalista-ufanista que, após uma sucessão de erros e acertos, atingiu seu momento ápice nos anos de 1950, sob os auspícios da cartilha da Comissão Econômica para a América latina e o Caribe, a Cepal.

Na vigência do governo de Juscelino Kubitschek (1956/1961), o Brasil experimentou um acelerado crescimento econômico graças ao Plano de Metas, baseado numa nova etapa de política de substituição de importações, inspirada nos preceitos da Cepal. A Cepal procurou explicar o atraso dos países da América Latina pela deterioração das relações de troca, pelos menores ganhos de produtividade e menor força da classe trabalhadora, defendendo o planejamento e a industrialização como forma de racionalizar a ação do setor público e promover o crescimento econômico (BIELSCHOWSKI, 2000).

No entanto, no período, alguns fatores fizeram com que se elevassem os déficits do governo de tal forma que se formou uma forte inflação de demanda nos primeiros anos da década de 1960. Apesar de registrar elevadas taxas de crescimento e de dotar o País de uma estrutura industrial integrada e diversificada, o governo de JK levou o de seu sucessor, Jânio Quadros (1961/61), sucedido por sua vez pelo governo de João Goulart (1961/1964), a enfrentar graves desequilíbrios internos e externos.

Pouco tempo depois, após o Golpe Militar que se seguiu em abril de 1964, no início do governo Castelo Branco (1964/1967) foi criado o primeiro Programa de Ação Econômica do Governo, o PAEG, cujos objetivos foram a formulação de políticas conjunturais de combate à inflação, associadas a reformas estruturais, que permitiriam o equacionamento dos problemas inflacionários causados pela política de substituição de importações e das dificuldades que se colocavam ao crescimento econômico. Isso requereu, na época, que fosse dado um segundo passo no processo: a expansão da então pequena indústria de base (siderurgia, energia, petroquímica) para evitar que o aumento da produção de bens industriais de consumo final, ampliada pela política de substituição 
de importações, provocasse um aumento insustentável nas importações brasileiras de insumos básicos que a indústria nascente consumia de forma crescente.

Em 1968, começa um período de relativa expansão econômica no Brasil conhecido popularmente como o "milagre econômico brasileiro", entre os governos de Costa e Silva (1967/1969) e Médici (1968/1973). Nesse período, em pleno regime militar, a economia brasileira dava sinais de crescimento, uma vez que crescia a uma taxa média superior, se comparada a períodos econômicos anteriores. O Estado investia na indústria pesada, siderurgia, petroquímica, construção naval e geração de energia hidrelétrica. As empresas estatais cresciam e obtinham grande lucratividade. O sucesso da política econômica no "milagre" logo se tornou evidente quando no Brasil houve um incremento na produção de bens de consumo duráveis e o de bens de capital (VASCONCELLOS, 1999).

Um fator relevante na esfera econômica brasileira que deve ser levado em consideração no período compreendido como "milagre" é a disparidade de renda da classe trabalhadora proporcionada pela contenção salarial imposta no regime militar, porque com o objetivo de controlar a inflação o governo fazia um rigoroso controle dos aumentos salariais e reprimia violentamente as manifestações de trabalhadores. Essa contenção salarial muito contribuiu para aumentar o abismo entre ricos e pobres nos anos de 1970 (MACIEL, 1999).

O "milagre" gerou também um desequilíbrio entre os diferentes setores da indústria, uma vez que se concentrou, principalmente, no setor de bens de consumo duráveis. Formou-se uma disparidade entre os diferentes setores da indústria porque a produção no setor de bens duráveis crescia a um ritmo mais acelerado do que nos setores de bens de capital (máquinas e equipamentos) e bens intermediários (petróleo, fertilizantes, produtos químicos etc.). Com o passar do tempo, essa disparidade intersetorial gerou um problema de dependência externa. Ou seja, o Brasil, por não ter o setor de bens de produção (de capital e intermediário) suficientemente desenvolvido, dependia da importação desses produtos (VASCONCELLOS, 1999).

No Governo Médici (1972/1974), no entanto, foi desenvolvido o I PND - Plano Nacional de Desenvolvimento, cujo principal objetivo era preparar a infraestrutura necessária para o desenvolvimento do Brasil nas décadas sequentes, com ênfase em setores como transportes e telecomunicações, bem como prever os investimentos em ciência e tecnologia e a expansão das indústrias naval, siderúrgica e petroquímica. Para 
isso, o governo articula empresas estatais, bancos oficiais e outras instituições públicas na elaboração de políticas setoriais.

A crise do petróleo, gerada em 1974, interrompeu o ciclo de crescimento exigindo reestruturação no andamento da economia nacional (HERMANN, 2005; REGO, 2005). Os países que tinham grande dependência do petróleo sofreram impactos com a alta dos valores, como foi o caso do Brasil, que importava quase que a totalidade do óleo bruto consumido no país (CARA; FRANÇA, 2009).

Não obstante, no Governo de Ernesto Geisel (1974/1979), sucessor de Médici, foi iniciado o II PND, como resposta à crise econômica decorrente do primeiro choque do petróleo, no fim do chamado "milagre econômico brasileiro", período auspicioso de alguns anos consecutivos de crescimento. No II PND foi almejado superar os desequilíbrios setoriais. Nesse momento, os projetos de investimento eram destinados à substituição de importações e à abertura de novas frentes de exportação. A resposta viria com um programa de redução de importações nos setores de bens de capital e insumos básicos como química pesada, siderurgia, metais não ferrosos e minerais não metálicos, ao lado de elevação da produção interna de petróleo e da ampliação de geração de energia hidrelétrica (FONSECA; MOREIRA, 2012).

O pacote de investimento abrangeu dentre vários setores da economia a expansão do setor de mecânica pesada, para ampliar a produção de máquinas e equipamentos. Esse plano é considerado a mais ampla experiência de planejamento econômico no Brasil depois do Plano de Metas e teve uma importância fundamental na consolidação do processo de substituição de importações ocorrido no Brasil.

Pode-se perceber um viés desenvolvimentista aos moldes da Cepal no plano, pois encampava a tradicional tese de que o estrangulamento externo incitava à continuidade do processo substituição de importações e, se necessário, por meio dos investimentos públicos (FONSECA; MOREIRA, 2012).

A estratégia industrial no período do II PND visava crescer a uma taxa anual de mais de $10 \%$ e estabeleceu entre outras metas o impulso ao desenvolvimento da indústria de alimentos, com continuação do esforço de modernização e reorganização de certas indústrias tradicionais e também a atenuação dos desníveis regionais do desenvolvimento industrial, evitando-se a continuação da tendência à concentração da atividade industrial em uma única área metropolitana. Dar-se-á estímulo a um melhor equilíbrio no triângulo São Paulo-Rio-Belo Horizonte, e aos polos industriais no Sul e 
Nordeste, procurando-se compatibilizar os movimentos de descentralização com a preservação de escalas de produção econômica e de economias de aglomeração.

O II PND alavancou diferentes segmentos da economia, além das fronteiras do eixo Rio-São Paulo, uma vez que estava em andamento no período um processo de estímulo à desconcentração industrial do Estado de São Paulo. O II PND, implantado durante o primeiro choque do petróleo pode ser considerado como um exemplo, embora não muito bem sucedido, de política anticíclica.

Contudo, Cano (2007, p. 23), salienta que a crise da economia internacional, que se inicia por volta de 1973 tomou rumos inesperados a partir de 1979, decorrentes da mudança da política fiscal dos Estados Unidos da América, como a elevação de sua taxa de juros. Subsequentemente os EUA, restaurariam sua hegemonia política e econômica. Nesse instante, o efeito imediato aos países menos desenvolvidos e muito endividados, como o Brasil, foi o corte considerável do financiamento externo, desdobrando-se em outros efeitos danosos: alta inflação, queda de investimento, baixo crescimento, crise crônica da balança de pagamentos, corte do crédito externo, elevação da dívida pública interna e externa, o que aprofundaria as crises fiscais e financeiras do País, debilitando cada vez mais o gasto e o investimento público.

Os objetivos de mudança estrutural que motivaram o II PND foram alcançados; todavia, os resultados concretos só vieram a acontecer entre os anos de 1983 e 1984 com a maturação dos investimentos realizados, dentre os quais três merecem destaque: a reversão do saldo da balança comercial, que se tornou superavitária; a dependência menor das importações de petróleo; e a maior diversificação na pauta de exportações do país, com predomínio de bens manufaturados, em lugar dos bens primários, como era no passado.

Apesar da expansão industrial, da riqueza acumulada e do desenvolvimento tecnológico desenvolvido no Brasil, Argentina e México no período anterior a crise do petróleo, em um período posterior, os anos de 1980 foram marcados pela brusca interrupção do crescimento, motivados por fatores internos e externos. O Brasil contraiu grande quantidade de empréstimos nas décadas de 1950 e 1960, pois eram adquiridos a juros considerados baixos, e com a crise no final dos anos de 1970, esses juros atingem valores exorbitantes e leva o Brasil a um endividamento e consequente estagnação da economia na década de 1980 (KATZ, 2005).

A década de 1980 é sinônima de crises econômicas, volatilidade de mercados, problemas de solvência externa e baixo crescimento do PIB (LOPES, 1989). Os anos de 
1980, para alguns países latino-americanos, são conhecidos como a "Década Perdida", no Brasil trouxe o final do ciclo de expansão dos anos de 1970. No período verificou-se uma forte retração da produção industrial e um menor crescimento da economia como um todo. Cano (2007, pp 23-24) ressalta que na chamada década perdida houve a diminuição da ação do Estado no plano nacional e regional e, debilitou também o investimento privado, especialmente o industrial, atingindo principalmente o parque industrial do Estado de São Paulo que estagnou, diminuindo os efeitos impulsionadores de desconcentração industrial.

Porém, a estagnação estimulou as exportações no Brasil, influenciadas pelo slogan de cunho "Exportar é o que Importa" ${ }^{16}$ (vigorou entre os anos de 1979 a 1985). As exportações cresceram 71\% entre 1980 e 1989, por outro lado, a recessão conteve as importações, que cresceram somente 24\%. Foram gerados, então, na década de 1980 US\$ 97 bilhões de saldos comerciais, incapazes frente ao que se remeteu de juros (US\$ 87 bilhões), além de outros pagamentos, para tentar evitar o aumento da dívida externa, a qual, entre o início e o fim da década, saltou de 64 para 115 bilhões de dólares (CANO, 2007. p.25).

Concomitantemente, na década de 1980, acentuavam-se as pressões exercidas sobre toda a América Latina pelos EUA para integrar-se ao Tratado de Livre Comércio (Nafta) com os Estados Unidos e o Canadá, e na Associação de Livre-Comércio das Américas (Alca). Cano faz crítica ao Mercosul, o Mercado Comum do Cone Sul das Américas, em face às enormes diferenças estruturais e institucionais entre seus países membros, da instabilidade macroeconômica e dos percalços neoliberais de suas políticas econômicas.

A partir da década de 1990, e da emergência das ideias neoliberais, o processo de industrialização do país toma novo rumo, com a privatização de grande parte das estatais e da abertura cada vez maior da economia do país ao capital internacional, além da retirada de direitos trabalhistas históricos. Cano (2007, p. 27) ressalta que o receituário neoliberal (aplicado para atender duas ordens de questões: a financeira e a produtiva) implicou a submissão consentida dos países menos desenvolvidos à Nova Ordem, representados pelos preceitos contidos no chamado Consenso de Washington,

${ }^{16}$ O slogan "exportar é o que importa" foi lançado no governo João Baptista de O. Figueiredo (19791985). A campanha baseava-se numa ideia ainda mais antiga, "exportar é a solução", de 1964. (http://www1.folha.uol.com.br/fsp/brasil/fc0409200103.htm) 
fazendo com que o Brasil abdicasse de sua soberania, no desenho, na implementação e no manejo da política econômica.

O primeiro receituário se impôs decorrente da crise financeira internacional que escancarou a supremacia do capital financeiro sobre outras formas de capital e impôs a quebra da soberania nacional dos países latino-americanos para liberar seu movimento internacional na busca incessante de valorização. O segundo receituário, explica-se pela reestruturação produtiva e comercial feitas pelas empresas transnacionais, em suas bases localizadas nos países mais desenvolvidos, que exigiam também na década de 1990, reestruturações semelhantes em suas bases localizadas nos países menos desenvolvidos.

Na virada para o século XXI, no segundo mandato do Governo do Presidente Luís Inácio Lula da Silva (2007-2010), é divulgado em janeiro de 2007, o Programa de Aceleração do Crescimento (PAC), um conjunto de investimentos públicos em infraestrutura econômica e social nos setores de transportes, energia, recursos hídricos, saneamento e habitação, além de diversas medidas de incentivo ao desenvolvimento econômico, estímulos ao crédito e financiamento, melhoria do ambiente de investimento, desoneração tributária e medidas fiscais de longo prazo (MINISTÉRIO DO PLANEJAMENTO - PPA 2008-2011, 2007).

O Programa de Aceleração do Crescimento (PAC) procurou a retomar o planejamento e a execução de obras de infraestrutura social, urbana, logística e energética do País. Nos seus primeiros quatro anos, o PAC intencionou melhorar os investimentos públicos brasileiros (de 1,62\% do PIB em 2006 para 3,27\% em 2010) e ajudou o Brasil a gerar um volume maior de empregos. Dentre os recursos destinados ao Setor Produtivo, 86,1\% (R\$ 656,6 bilhões) referem-se a despesas relacionadas a Comércio e Serviços, $11,5 \%$ à Agricultura $(\mathrm{R} \$ 87,5$ bilhões) e à 2,4\% Indústria $(\mathrm{R} \$$ 18,4 bilhões) (MINISTÉRIO DO PLANEJAMENTO - PPA 2008-2011, 2007).

O PAC teve importância para o Brasil durante a grave crise financeira mundial deflagrada entre 2008 e 2009, pois concentrou esforços para assegurar o nível emprego e renda aos trabalhadores, o que por sua vez garantiu a continuidade do consumo de bens e serviços, mantendo ativa a economia e aliviando os efeitos da crise sobre as empresas nacionais (MINISTÉRIO DO PLANEJAMENTO - PAC, 2014).

Em 2011, o PAC entrou na sua segunda fase, com os mesmos intentos estratégicos da fase anterior em parceria com Estados e Municípios. 


\subsection{INDÚSTRIA GAÚCHA}

A trajetória econômica do Brasil pode ser vista por intermédio de algumas fases produtivas expostas na Figura 2.4.1: 1) da produção de açúcar; 2) da mineração no Centro-Oeste, no século XVII, com sua comercialização através do Rio de Janeiro e articulações com o Nordeste e o Extremo Sul; 3) da urbanização e da burocratização imperial, determinado pela fixação da Coroa Portuguesa no Rio de Janeiro; 4) do café, no eixo Rio/São Paulo; 5) da indústria tradicional; 6) do surgimento da indústria de base; 7) da concentração da indústria tradicional; e 8) das falências, fusões, transferências de controle acionário e desnacionalização, iniciado na crise econômica de 1963-68 (CARRION JR., 1986, p. 18).

Em conexão com a economia brasileira, o Rio Grande do Sul já no final do século XVII ligava-se à economia do Sudeste e Nordeste do Brasil, no período da mineração, cuja participação era verificada pelo abastecimento de alimentos àquelas regiões (Figura 2.4.1) e posteriormente, na fase industrial (Figura 2.4.1) pela produção de bens tradicionais entre os anos finais do século XIX e as primeiras décadas do século XX. A primeira fase da industrialização rio-grandense é resultante de um processo relativamente espontâneo que se desenvolveu a partir de espaços vazios determinados pelas limitações às importações anteriores às grandes guerras até os anos de 1930. 


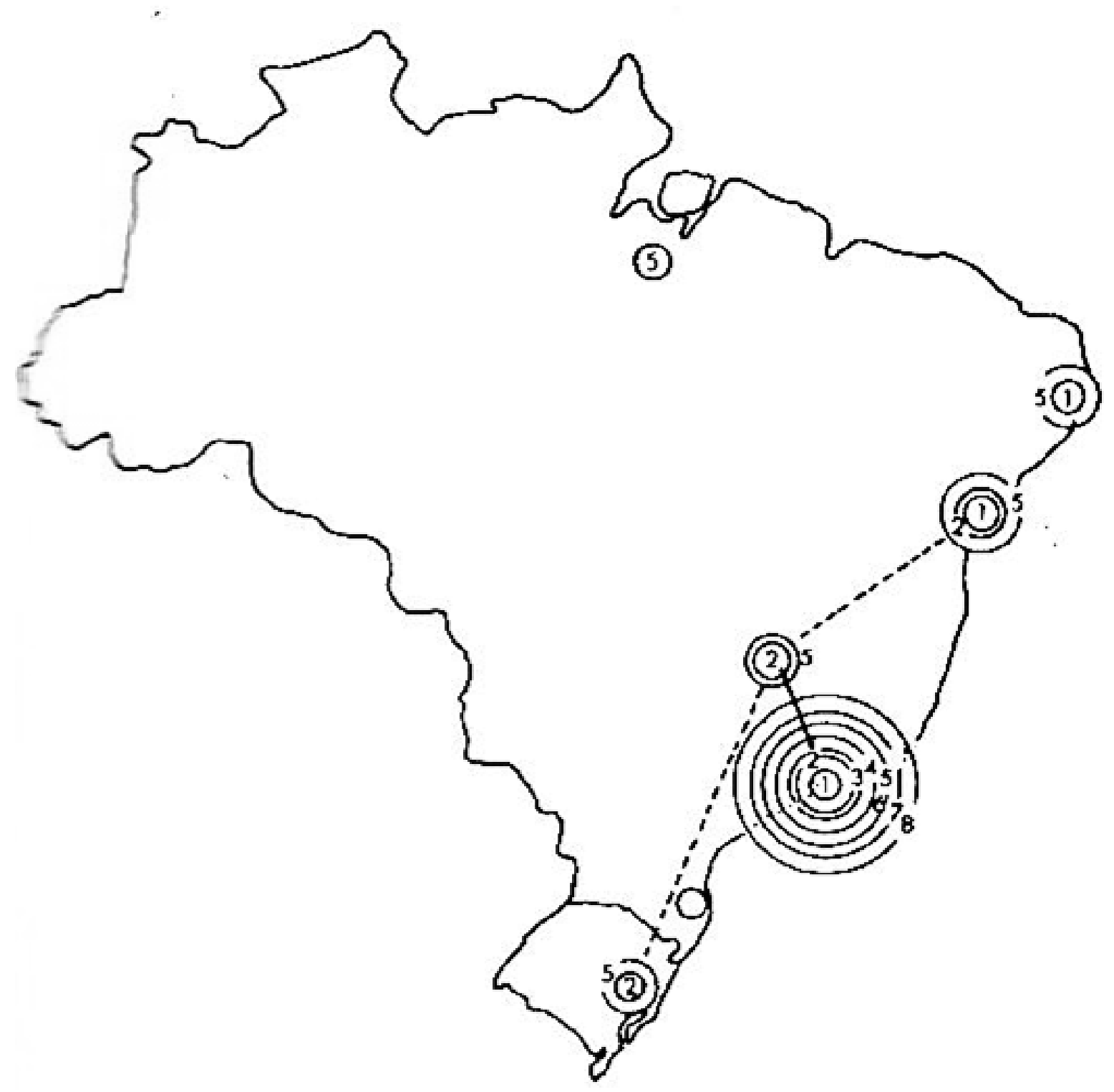

Figura 2.4.1 Fases econômicas brasileiras

Fonte: Carrion Jr. p. 17.

As atividades geradoras de renda estáveis no território do Rio Grande Sul sofreriam com a instabilidade política e as lutas (CASTRO, 1975). A Revolução Farroupilha, que se estendeu de 1835 a 1845, foi fruto de uma crise armada entre a capital federal (Rio de Janeiro) e a província do Rio Grande do Sul que reivindicava, entre outras coisas, maior autonomia econômica e uma política de proteção à pecuária face à concorrência com o charque uruguaio e argentino (PILLAR; BENADUCE, 2009, p. 119). Com isso, os benefícios dos imigrantes europeus só serão sentidos nos últimos anos do século XIX (CARRION JR. 1986, p. 15). 
O imigrante europeu preocupou-se em ser colonizador e fixar núcleos de produção de gêneros para o mercado interno, ao contrário dos imigrantes instalados no restante do País, que vieram, essencialmente, para substituir a mão-de-obra escrava. Primeiramente chegaram ao Rio Grande do Sul os imigrantes alemães, que se estabeleceram em pequenas propriedades rurais, onde desenvolviam uma agricultura que beneficiou o pequeno proprietário e o comerciante, promovendo a acumulação de capitais.

Os colonos italianos vieram mais tarde, e sua situação diferiu da dos alemães. Isso porque, chegando depois, ficaram com as terras mais afastadas e tiveram que enfrentar a concorrência da produção de cereais que era uma atividade tradicional do povo alemão (PILLAR; BENADUCE, 2009, pp. 117-118).

Roche (1969, p. 504) afirma que, com exceção do primeiro estaleiro gaúcho, a empresa Só e Cia, fundada em 1850, os demais estabelecimentos industriais pioneiros desse Estado foram criados por empreendedores de origem alemã. A participação desses imigrantes, como se vê, é notória.

Em 1874, fundava-se na cidade de Rio Grande a primeira grande fábrica alemã, a fiação Rheingantz que posteriormente receberá outra denominação. A fundação da fábrica marca o início propriamente da indústria gaúcha. A segunda foi a empresa de J. C. Lang, em Pelotas, que utilizava os subprodutos das charqueadas para fabricação de sabão e velas (ROCHE, 1969, pp. 504-505).

Tão logo chegam ao RS, os imigrantes alemães dão início a uma agricultura comercial, na qual a produção de trigo ganha destaque e desde então são registradas exportações através da nascente Porto Alegre. O êxito da agroindústria do charque, combinado com o desenvolvimento da agricultura cerealífera açoriana, já levara a província ao êxito. Contudo, o surgimento de uma agricultura de base da pequena e da média propriedade daria renovadas possibilidades de ascensão à Província do Rio Grande do Sul. Os imigrantes de origem europeia em São Paulo, além de criarem um amplo mercado interior, favoreceram a produção de cereais do extremo-sul, pois os trabalhadores italianos de São Paulo eram grandes consumidores de trigo e vinho. Isso introduziu radical mudança dos hábitos de consumo tanto no ambiente rural como no urbano, uma vez que se processava um contínuo crescimento das cidades (CASTRO, 1975, pp. 44-46).

A indústria do RS esteve voltada para dois mercados internos: num primeiro momento, o regional e, logo depois, o nacional. É a partir dessa dualidade de mercados 
que se compreendem certas características, como também o próprio ritmo e o rumo tomados pelo desenvolvimento industrial do RS. Fundamentalmente, o RS insere-se no mercado a partir das atividades agrícola e pecuária, com a participação efetiva do imigrante.

O desenvolvimento industrial gaúcho na República Velha (1889-1930) acompanhou as tendências gerais do processo de industrialização que ocorria no Brasil durante a vigência do modelo de desenvolvimento denominado "crescimento para fora". Crescimento para fora se constituiu como um período de ascensão da econômica gaúcha, cuja produção era voltada para atender o crescimento do mercado interno brasileiro. Este procurava tirar da pauta das importações os produtos manufaturados da indústria tradicional que exigiam pequeno volume de capital. A indústria dessa manufatura possibilitou a importação de tecnologia obsoleta dos países mais industrializados (REICHEL, 1979).

A estatística industrial rio-grandense, bem como do resto do País, só aparece em 1907. No período citado, existiam 212 estabelecimentos industriais e, em 1908, o número de operários passará, em um ano, de 10.940 para 15.426; o capital, de 38.000 contos para 49.000. O RS teria contado, em fins de 1909, 569 estabelecimentos industriais, entre os quais 369 fundados entre 1900 e 1909, ou seja, 64\%, sendo os ramos mais importantes a alimentação (160), a madeira (100), a cerâmica (57), a metalurgia (43), couros (42), as roupas feitas (41) e os produtos químicos (37). Contudo, o crescimento da indústria, durante esse período, é bem inferior ao do decênio seguinte, visto que, de 1910 a 1919, fundaram-se 1143 novos estabelecimentos (ROCHE, 1969, p. 508).

Apesar de grande parte da atividade industrial rio-grandense associar-se à transformação de produtos agrícolas e pecuários, havia um fator diferencial: a presença marcante da indústria têxtil. Para esse ramo de atividade era canalizada grande soma de capital, acima da média estadual e sua destinação em grande parte seguia para fora da região. Com a empresa têxtil União Fabril, sucessora da Rheingantz, teve início efetivamente a indústria gaúcha, já que ela não visava tão somente ao mercado regional (MOREIRA; COSTA, 1995, p. 94-95). A Cia União Fabril, conforme Roche (1969, p. 507) exportava 2/3 de sua produção para o Rio de Janeiro, desde 1896.

Os tecidos figuram na lista dos dez principais produtos exportados. As maiores indústrias têxteis do RS, conforme menciona Reichel, eram: 
a Cia União Fabril (ex Rheigantz \& Vater) de Rio Grande; a Cia de Fiação e Tecidos Porto-alegrense, de Porto Alegre; Cia fabril Porto Alegrense Santos, Bocchi \& Cia, também de Porto Alegre; Cia de Tecelagem Ítalo-Brasileira, de Rio Grande e Cia de Fiação e Tecidos Pelotense, de Pelotas, as quais foram sendo fundadas entre os anos de 1874 e 1908 (1979, p. 257).

A indústria do RS se apresenta formada essencialmente por empresas com baixo volume de capital investido, o que autoriza a argumentar que esse perfil industrial se justifica por um baixo nível de tecnologia e uma estrutura quase artesanal. Salienta-se ainda que, no início do século $\mathrm{XX}$, as exportações representavam uma porcentagem reduzida da produção e o grande volume delas era destinado ao abastecimento interno estadual.

O período pós-guerra traz o declínio de instalação de empresas industriais em todo o Brasil. Em 1912, o cômputo delas no País era de 9.475 e, no RS, era de 1.199, ao passo que, em 1920, após a I Grande Guerra, no Brasil esse número decairá para 3.850 no País, e 453 no RS. Porém, o capital investido quase dobrou. Em 1912 era de 485.011 e 32.036 contos, respectivamente no País e no Estado, e, em 1920, 939.214 e 5.9462, respectivamente (Tabela 2.4.1) (ROCHE, 1969, p. 511). O confronto dessas duas séries de cifras confirma que se o número de empresas diminuiu, a partir do fim do conflito bélico mundial, a indústria do RS manteve uma atividade superior à que tinha antes da guerra.

Tabela 2.4.1. Número de estabelecimentos industriais entre 1912 e 1920 no Brasil e RS.

\begin{tabular}{|l|rc|c|rr|l|}
\hline & \multicolumn{2}{|c|}{ Número de estabelecimentos } & Diminuição & \multicolumn{2}{|c|}{ Capital (contos) } & Aumento \\
& 1912 & 1920 & & 1912 & 1920 & \\
\hline Brasil & 9.475 & 3.850 & $59,3 \%$ & 48.5011 & 93.9214 & $93,6 \%$ \\
RS & 1.199 & 453 & $58,0 \%$ & $3.2036 \quad 5.9462$ & $85,6 \%$ \\
\hline
\end{tabular}

Fonte ROCHE, 1969, p. 511.

A consolidação da pecuária e da agricultura diversificada dos colonos alemães e italianos atribuiu ao RS crescente importância na economia brasileira. O sul do Brasil conseguiu progressivamente inserir-se num esquema nacional de divisão do trabalho. A solidez alcançada pelo Estado, mesmo após muitos percalços, antes e depois do início do século XX, apresenta-se inegável (CASTRO, 1975, p. 46). 
Passados mais alguns anos, a mostra do perfil da indústria no Brasil, conforme recenseamento de 1920 conservar-se-á mais ou menos idêntica ao censo de 1907, tanto no que diz respeito à sua dispersão geográfica como à distribuição percentual da produção. Porém, com uma modificação visível: o primeiro lugar passa ser representado pelas indústrias de alimentação, que no censo anterior colocava-se em segundo lugar. A I Guerra Mundial estimulou a exportação brasileira de carne congelada, quase nula antes do conflito, e, em 1918, eleva-se para 60.509 toneladas anuais. Essa indústria de carnes localizava-se precisamente no Rio Grande do Sul, na época o principal centro pecuário do Brasil, desde o século XVIII. (PRADO JR., 1971, pp. 261-262).

O RS, em 1920, ocupou o terceiro lugar entre as demais unidades, vindo a se posicionar novamente logo após São Paulo e o Distrito Federal (RJ): seus 1773 estabelecimentos possuíam 13,8\% do capital investido nas fábricas, 9,5\% da força motriz, 9\% dos operários e produziam 11,8\% do total nacional (ROCHE, 1969, pp. 511512).

Associado ao processo de industrialização, um aspecto muito relevante aos estudos geográficos diz respeito ao crescimento das cidades, uma vez que as indústrias atraem sempre mais habitantes e favorecem a expansão urbana. Esse pressuposto teórico coube também ao Rio Grande do Sul, pois a formação histórica de seus maiores municípios está atrelada às instalações fabris (produção de carne e couro). Entre 1874 e 1915, a atividade fabril ganha destaque no desenvolvimento de cidades como, Rio Grande, Caxias do Sul, Porto Alegre e São Sebastião do Caí (PILLAR; BENADUCE, 2009, p.120).

O município de Pelotas, no final do século XIX, foi centro da atividade saladeira formando um dos primeiros núcleos industriais do Estado, com destaque para a produção de charque e de couro. Entretanto, a industrialização passa a ganhar contundência em áreas de colonização alemã e italiana, impulsionada pela acumulação de capitais das atividades agrícolas desenvolvidas pelos imigrantes. Grandes frigoríficos de capital estrangeiro se instalaram no sul do Estado, como em Pelotas e Rio Grande e na Região da Campanha rio-grandense (Armour, em Santana do Livramento, e Swift, em Rosário do Sul).

À retaguarda do crescimento da indústria no Rio Grande do Sul inicia-se o êxodo rural cuja principal consequência é a transferência de uma massa de trabalhadores do campo para as cidades, absorvidos pouco a pouco nessa atividade econômica. Ainda que a industrialização gaúcha tenha iniciado em áreas de imigração alemã e italiana, 
com o passar do tempo, as estruturas produtivas passaram a ser transferidas para as áreas de imigração açoriana, como Porto Alegre, Pelotas e Rio Grande, motivadas pela localização geográfica dessas cidades que facilitava o transporte dos produtos para a exportação (PILLAR; BENADUCE, 2009; MOREIRA; COSTA, 1995).

Apesar de já existirem alguns estabelecimentos industriais de certa magnitude, como o Estaleiro Becker em Porto Alegre, em 1865, somente no início dos anos de 1900 é que a região de Porto Alegre passa a comportar fábricas de grande porte e sensivelmente se assumir como uma região do Estado com propensões ao desenvolvimento econômico. Desta forma, segundo Moreira e da Costa (1995, p.95) "a região de Porto Alegre começou a suplantar o sul do RS, a partir dos anos de 1900, quando se firmou como centro industrial diversificado, abastecendo o amplo mercado da região colonial rio-grandense". Antes mesmo da Segunda Grande Guerra criaram-se importantes fábricas na Grande Porto Alegre, reafirmando a sua liderança na economia estadual. No entanto, o forte setor secundário do RS continuava associado à produção primária (carne, vinho, tecidos de lã e calçados).

Nos anos de 1950, a integração das economias regionais e a formação de um mercado nacional unificado, facilitada pela política desenvolvimentista do governo de Juscelino Kubitschek com o Plano de Metas, romperam as barreiras ao livre fluxo de mercadorias e capitais, intensificando a concorrência. Daí que as áreas mais próximas ao mercado consumidor tornaram-se mais atrativas ao investimento de capitais e capazes de concorrer com mais eficiência no mercado (ROTTA, 1999).

Na vigência do Plano de Metas, em meados dos anos de 1950, o Rio Grande do Sul foi relegado a um plano menor, porque recebeu uma parcela pouco significativa de investimentos do Governo Federal para promover o seu desenvolvimento industrial em relação ao Estado de São Paulo, o mais desenvolvido. Nesse sentido, a década de 1950 foi um período desfavorável para a indústria gaúcha, que cresceu não só abaixo da média nacional, mas bem abaixo do complexo econômico paulista. Por sua vez, a indústria de SP avança cada vez mais e se consolida, tanto que em 1960 obtinha 55,08\% do valor da produção industrial do País. A par disso, para a indústria gaúcha, esse é novamente um período de perda, que decresce de 8,59\% para 7,13\% do valor da produção nacional. Em termos de renda setorial, a indústria do RS, que gerava 6,67\% do total do país, declinou para 5,41\% em 1960, perdendo 1,26 ponto percentual. (FEE, 1983, v.2, p.37-9). Desse modo tendo o RS uma estrutura industrial de pequenas fábricas e baixa acumulação de capital, o resultado da integração e da característica de 
grandes unidades de produção no centro do país, aptas a atender o mercado interno, foi novamente a perda de participação nacional de suas indústrias. Ao contrário, a indústria paulista continuava a concentrar os maiores empreendimentos (PEREIRA; ARENDT, 2003).

Entretanto, foram as indústrias de bens de capital que tiveram as mais altas taxas de crescimento, após os anos de 1950, em parte devido à expansão da produção de máquinas e implementos agrícolas. A expansão da indústria de bens de capital no Rio Grande do Sul desencadeou importantes avanços para o setor produtivo no Estado nos ramos da mecânica e de material de transporte. Dentro desses ramos estão os produtores de máquinas e implementos agrícolas, máquinas-ferramenta, máquinas operatrizes, aparelhos industriais e carrocerias para veículos automotores. Dessa forma, a indústria de bens de capital do RS passou a ter uma composição mais equilibrada, tornando-se mais completa ao desenvolver os ramos preexistentes e instalar novos ramos, integrando-se à dinâmica da acumulação nacional (PEREIRA; ARENDT, 2003).

Também se fez muito importante para a mudança estrutural na indústria gaúcha em todo o período o segmento de bens intermediários ${ }^{17}$, que, em 1970, se destacava representando aproximadamente $37 \%$ do montante industrial. As taxas de crescimento da indústria de bens intermediários do Rio Grande do Sul, apesar de terem sido menos regulares, apresentaram uma correlação perfeita com as do produto industrial brasileiro "enquanto o Rio Grande do Sul detinha, em 1959, somente 2,9\% do valor bruto de produção (VBP) do setor, São Paulo concentrava 85,4\% do mesmo total. Além disso, pode-se dizer que qualitativamente aumentou a diferença entre a indústria de bens de capital de São Paulo e do Rio Grande do Sul” (FEE, 1986, p.42).

O comportamento da indústria de bens intermediários deve ter sido determinado por fatores exógenos à economia gaúcha, relacionado com as taxas de crescimento do produto nacional brasileiro. A forma de vinculação da indústria gaúcha no novo padrão de acumulação tornou-a muito mais sujeita às flutuações cíclicas da economia brasileira.

\footnotetext{
${ }^{17}$ A partir de meados da década de 1950, o RS insere-se na nova dinâmica de acumulação nacional: "O parque fabril do Rio Grande do Sul passou a articular-se ao centro dinâmico do País, fundamentalmente, via produção de insumos industriais (matérias-primas, peças e componentes etc.). E, dada a importância crescente dos estabelecimentos produtores de bens intermediários (ou insumos) na configuração industrial do Estado, evidencia-se que a economia gaúcha tende a ficar cada vez mais atrelada à brasileira. Também os gêneros produtores de bens de capital têm crescido a taxas bastante elevadas no Estado" (EINLOFT, 1982, p. 8).
} 
É justamente a partir deste novo padrão que a produção industrial do Estado torna-se mais instável, sendo que as maiores oscilações das taxas de crescimento couberam ao setor produtor (FEE, 1986, p. 42).

As indústrias químicas, metalúrgicas, mecânicas, de material de transporte, de material elétrico, de comunicações e de papel/papelão (bens intermediários) nos anos de 1970 no RS, perfazem 50\% do produto industrial, cuja destinação ao consumidor final só ocorrerá após receber um processo final de elaboração e montagem em empresas do Centro-Sul, pois essas passam definidoras das condições de lucro e, portanto, as detentoras das maiores fatias de valor agregado dos produtos (CARRION JR., 1981, pp. 38-39).

Passado o período expansivo do processo substitutivo de importações no Brasil, na década de 1980, observou-se o esgotamento das políticas industriais patrocinadas pelo Estado, reduzindo-se drasticamente o investimento público. Pereira e Arendt (2003, p.17) acreditam que a estrutura industrial do Rio Grande do Sul durante os anos de 1980 não se diferenciou do período anterior e que na década de 1990, também não trouxe alterações significativas para a estrutura da indústria gaúcha. O Rio Grande do Sul chegou aos anos 1990 com sua estrutura industrial não muito diferenciada da década de 1980.

O Brasil vinha, desde os anos de 1980, enfrentando um forte processo inflacionário e grande volume de dívida externa, no entanto, a implantação e a consolidação do Plano Real, em meados dos anos de 1990, associado a um processo político estável, culminou em uma vitória de toda a sociedade brasileira, que conseguiu enfrentar e vencer as crises externas ocorridas no México, Rússia e Coréia do Sul (SOUZA, 2001).

Os anos de 1990 foram caracterizados pela abertura da economia brasileira às importações no contexto do plano nacional de modernização industrial e pelo fim do processo inflacionário. No período, a economia mundial passou por uma grande transformação, fruto de uma notável mudança tecnológica, como a robotização do processo produtivo, acarretando considerável economia de mão-de-obra; novos produtos revolucionários (informática, eletrônica, comunicações); globalização dos capitais fixos e financeiros; intenso processo de privatizações, que atingiu fortemente a economia brasileira e a formação e a consolidação de blocos econômicos regionais (SOUZA, 2001 e 2002). O exemplo mais localizado da consolidação de um bloco 
econômico regional se deu entre os países do Cone Sul da América, o Mercado Comum do Sul - MERCOSUL.

As políticas comerciais na década de 1990 objetivavam também combater a inflação, ao aumentar a oferta interna de bens. A abertura comercial e a modernização tecnológica afetaram igualmente a economia gaúcha. Em 2000, os principais segmentos industriais do RS eram representados pelos calçados, alimentos, bebidas, construção civil, metalurgia, madeira, mobiliário, borracha, fumo e couros. Entre 1990 e 2000, a indústria do RS criou 24.766 empregos (4,4\%), enquanto no conjunto do Brasil houve queda de 590.542 empregos (-8,6\%) (SOUZA, 2001).

No contexto do Rio Grande do Sul, o crescimento do emprego do conjunto da indústria deveu-se, basicamente, ao desempenho da construção civil, dos setores de alimentos e bebidas, madeira e mobiliário e química. Souza (2001) salienta também que o desemprego foi substancial nas indústrias têxtil, borracha, fumo/couros, metalúrgica e mecânica. Serviços industriais de utilidade pública ${ }^{18}$ desempregaram quase três mil pessoas na década de 1990. Na dimensão nacional, o autor salienta que as poucas indústrias que criaram emprego foram: construção civil, alimentos e bebidas, madeira e mobiliário e calçados; enquanto as que mais desempregaram em nível nacional foram: borracha, fumo e couros, têxtil, eletrônica e comunicações, mecânica e metalúrgica. Isso se deve à reestruturação da indústria brasileira provocada pela abertura às importações, que aumentou a concorrência interna de produtos importados, como facilitou a importação de máquinas e equipamentos que gerou desemprego tecnológico.

Nos primeiros anos da década de 2000, a indústria gaúcha cresceu em ritmo superior ao conjunto do Brasil, embora com a presença das altas taxas de juros e taxa cambial valorizada, reduzindo a competitividade das exportações brasileiras. Pode-se atribuir o melhor desempenho da indústria gaúcha, assim como do conjunto da economia, às boas safras ocorridas em 2003 e 2004, o que explicaria também a recessão ocorrida no conjunto da economia em 2005, através da forte estiagem ocorrida nos verões de 2004 e $2005^{19}$.

\footnotetext{
${ }^{18}$ Serviços industriais de utilidade pública correspondem à atividade que abrange as empresas geradoras e distribuidoras de energia elétrica de origem hidráulica, térmica, nuclear, eólica, solar e outras. São os que produzem renda mediante uma remuneração da utilidade usada ou consumida.

${ }^{19}$ Ver item 4.3 - Produtividade Agrícola.
} 
A estiagem de 2005 reduziu em até $70 \%$ a produção de soja e milho no RS (FEE, 2005, EMATER, 2005). O fator climático se constitui em um fator agravante de redução da renda dos produtores agrícolas que têm dificuldades para saldarem as suas dívidas. Associado às dificuldades provenientes das condições severas do clima, os preços pagos muitas vezes são inferiores aos custos de produção. Os agricultores reclamam que além dos baixos preços pagos pela produção, outros entraves se dão pela elevada carga tributária e a precariedade da infraestrutura de transportes.

O desempenho da indústria gaúcha é calculado pela Federação das Indústrias do Estado do Rio Grande do Sul FIERGS, com base na agregação dos seguintes indicadores de conjuntura: a) compras totais de insumos; b) vendas totais; c) grau de utilização da capacidade instalada; d) horas trabalhadas na produção; e) salários totais pagos.

\subsection{INDÚSTRIA LOCAL}

Decorrentes da concentração industrial em algumas áreas preferenciais do território do Rio Grande do Sul, como os núcleos urbanos de Pelotas e Rio Grande no sul do Estado, de Caxias do Sul na Região da Serra e os núcleos da Área Metropolitana de Porto Alegre, surgem disparidades econômicas regionais que marcam uma indústria de desenvolvimento singular.

A Fronteira Noroeste do Rio Grande do Sul passa a conviver, a partir de meados do século passado, com a concorrência de produtos advindos de outras áreas do Estado, o que causa sua relativa perda de competitividade. Nesse período começam as dificuldades de reprodução da agricultura familiar, do pequeno comércio e da indústria tradicional (ROTTA, 1999). O esforço em promover o crescimento do Noroeste do RS está alinhado ao pensamento que busca a inserção competitiva de mercado a partir dos anos de 1950. A ideologia desenvolvimentista insere-se no seio da região, vinculada ao pensamento neoliberal de competitividade. E essa inserção ocorre de modo irreversível dentro de uma estrutura fundiária regional (ROHLEDER, 2003, p. 83).

Em âmbito regional, com a implementação da matriz produtiva agroexportadora surge uma nova elite local, representada por comerciantes de insumos e empresários agrícolas, ambos ligados à modernização da agropecuária (AZAMBUJA, 1991, apud 
ROHLEDER, 2003). Esta nova elite local reproduz estímulos externos, integrando-se de modo funcional à dinâmica nacional e internacional daquele setor.

A revolução verde ${ }^{20}$ que transformou a região em grande centro produtor vinculado ao modelo agroexportador nacional representa esta inserção. No entanto, representou limitações na construção de uma região mais densa, cultural, social e economicamente. Rohleder (2003, p. 84) frisa que o segmento social hegemônico local articulou e aceitou a introdução da modernização agricola como a "vocação economica regional'. Não obstante, a articulação em caráter regional, pensada e articulada a partir de interesses externos, se deu através de alguns exemplos como pelo surgimento de cooperativas, centros experimentais e cursos técnicos voltados à atividade agrícola.

Apenas parte da sociedade regional ascendia ao novo patamar da ideologia do trabalho de resultados em função do e para o mercado. A grande parcela da população rural tornou-se dispensável, devido à incapacidade relativa de gerar relações de troca. Desse modo, conforme salienta Rohleder (2003, p. 84), pode-se aceitar que enquanto fruto de relações das atividades capitalistas, esta opção para o desenvolvimento da Região Noroeste esteve de acordo com os anseios de um período histórico que antevia na noção de progresso o caminho para o desenvolvimento.

Pelo modelo de desenvolvimento implementado a partir dos anos de 1950, a região enfrentaria algumas dificuldades que se intensificam a partir dos anos finais dos anos de 1970 e início dos de 1980, devidas tanto ao modelo de desenvolvimento adotado na região até então, como a fatores externos decorrentes da crise do modo capitalista de produção, sentida no Estado e no resto do País (ROTTA, 1999; ROTTA E DALLABRIDA, 2007).

Uma vez que se fazia imprescindível para a economia local a adoção de um novo modelo tecnológico, de regulação, de organização do trabalho e de acumulação, exigia-se adequação imediata conjuntural. Para isso é que na década de 1980 houve a necessidade da mobilização de diversos segmentos pela elaboração e execução de propostas capazes de encaminhar soluções para os problemas enfrentados, ou seja, produzir alternativas capazes de dar conta dos novos desafios cobrados pela reestruturação (BECKER, 2000; BUTTEMBENDER 2000, 2005; DALLABRIDA, 2000; ROTTA; DALLABRIDA, 2007; VEIGA, 2006).

\footnotetext{
${ }^{20}$ Ver mais adiante (4.1) o que foi a revolução verde.
} 
A modernização da agricultura através da prática da monocultura, iniciada na década de 1960 com a soja, colocava à disposição dos agricultores recursos do crédito agrícola subsidiado pelo Sistema Nacional de Crédito Rural. O crédito tornou possível a compra e introdução de máquinas, implementos, sementes selecionadas, adubos químicos, agrotóxicos e levou a agroindústria a um novo patamar de crescimento que se propagou nos anos de 1970. Pelo sistema de crédito, os agricultores da região tiveram a oportunidade de financiarem a produção e o acesso a subsídios diretos do Governo, os que lhes permitiam a compra de insumos e a realização dos investimentos recomendados pelas indústrias ligadas à agricultura (ANDRIOLI, 2007, p. 259).

Apesar do pacote de incentivos públicos, por vezes muitos agricultores enfrentavam o desperdício na utilização de insumos, como perdas do solo produtivo por erosão - que destruía sua estrutura (areias, argilas, óxidos e húmus), levando os componentes para as partes baixas do relevo - e por lixiviamento, processo pelo qual a grande quantidade de chuva carrega os nutrientes do solo, deixando-o carente de potássio e nitrogênio. Tais fenômenos geomorfológicos tornaram-se recorrentes na região nas últimas décadas do século passado.

Com a crise do capitalismo mundial, deflagrada nos primeiros anos de 1970, os economistas neoliberais defendiam a redução da intervenção do Estado na economia por meio da privatização e da desregulamentação das atividades econômicas. Isso posto em prática, as funções relacionadas com o bem-estar social foram diminuídas.

O cenário dos anos finais de 1970 e início dos anos de 1980 em âmbito local/regional foi de um período propício para a queda de investimentos externos, fuga de capitais locais e de efetivo humano devido ao aumento do êxodo rural para áreas riograndenses mais bem posicionadas economicamente, uma vez que dispunham de mais ofertas de mão-de-obra por concentrarem a atividade industrial e diversos serviços. É o caso das regiões serrana e metropolitana de Porto Alegre, configuradas como mais dinâmicas e atrativas, sujeitas a maiores investimentos, em função da proximidade de um mercado consumidor mais volumoso, à diferença de outras regiões tidas como periféricas, cuja atividade agropecuária e cujo setor de serviços consistiam ainda nas principais fontes de recursos. Poucos municípios possuíam um setor secundário representativo na região. Essa realidade citada se configura como uma das razões das desigualdades regionais que ainda se configuram no Estado.

A capacidade de o Governo realizar investimentos ou fornecer incentivos ao processo produtivo também se reduziu drasticamente nos anos de 1980, como 
consequência do esgotamento do sistema fiscal, da posição subalterna do Rio Grande do Sul no contexto da economia nacional e de um conjunto de soluções da política fazendária marcadas pela imprevidência. Daí então, "os investimentos tornaram-se residuais, dependendo do sucesso do governo em reduzir suas despesas com pessoal e serviços da dívida e também da evolução da atividade econômica, que influencia o comportamento do ICMS" (WINCKLER; MOURA NETO, 1992, p. 117). A situação foi típica dos anos de 1980.

O crédito rural, que serviu para introduzir os agricultores no processo de modernização da agricultura, foi sendo suprimido a partir dos anos de 1980 e, quando as dívidas dele decorrentes precisaram ser saldadas, iniciou-se um processo de endividamento dos agricultores (TAMBARA, 1985).

Aos poucos, a inserção dependente fez com que se intensificasse um sistema de trocas desiguais que foi ampliando o processo de descapitalização dos agentes econômicos locais (agricultores e empresários) que limitavam suas condições para a realização de novos investimentos no processo produtivo. Para adquirir insumo, tecnologia, máquinas e implementos agrícolas, os agricultores foram obrigados a recorrer sistematicamente ao crédito financeiro (ROTTA; DALLABRIDA, 2007, p. 47).

Entra em declínio o modelo já estruturado na microrregião Fronteira Noroeste, que se configurava a partir da modernização da agricultura e da agroindústria, aliada a uma forte dependência do Estado em subsidiar o processo produtivo funcionando como agente indutor do desenvolvimento. A incapacidade do Estado brasileiro de continuar desempenhando essa função, em razão do tamanho de sua dívida e da redefinição do seu papel diante do processo econômico gerou a necessidade de recorrer a novos padrões de financiamento, seguro, assistência técnica, comercialização, política de preços e inserção no mercado (ROLHEDER, 2003, p. 50; BRUM, 2003, apud ROTTA; DALLABRIDA, 2007, p. 45).

Os novos padrões de desenvolvimento regional exigiram um repensar de toda a estrutura montada para dar suporte ao processo produtivo. As principais consequências para a região de Santa Rosa foram a redução dos investimentos públicos em infraestrutura de transportes, armazenagem, energia e comunicações e a queda na capacidade de financiamento da produção.

Conforme salienta Andrioli (2007, p. 258), as novas tecnologias, introduzidas com a modernização da agricultura, tem provocado o aumento dos custos de produção, transformando os 
agricultores em consumidores de insumos fornecidos pelas agroindústrias. Se em 1949 os agricultores gastavam pelo menos 15\% com insumos agrícolas, em 1965 esse valor subiu para 23,5\% e em 1980 atingiu praticamente $40 \%$.

As transformações na economia da soja, acelerada pelos produtos transgênicos e as mudanças mercadológicas (preços mais baixos e mercados asiáticos em transformação) atingem diretamente ao produtor de soja do Noroeste do Estado do RS. Esse produtor, cuja grande maioria possui menos de 50 hectares de terra arável passa a ser potencialmente um excluído do antigo modelo agrícola soja-trigo. A falta de escala para se manter em soja, a falta de subsídios oficiais, a nova realidade do trigo nacional, são alguns dos fatores que o encaminha para um modelo de diversificação (Brum, 2001, pp. 101-102).

Uma vez acentuado seu grau de especialização, o setor agrícola do RS incluindo por sua vez a sua porção Noroeste e as suas diversas microrregiões se transforma em exportador a fim de gerar divisas essenciais que custeiem as importações necessárias ao sofisticado polo que se desenvolvia na Região Sudeste do Rio Grande do Sul, entendendo esta como a área formada pelos Conselhos Regionais de Desenvolvimento (Coredes) do Vale do Paranhana, do Vale do Caí, do Vale do Rio dos Sinos e Metropolitana Delta do Jacuí que podem ser vistos no mapa dos Coredes da Figura 2.5.1. 


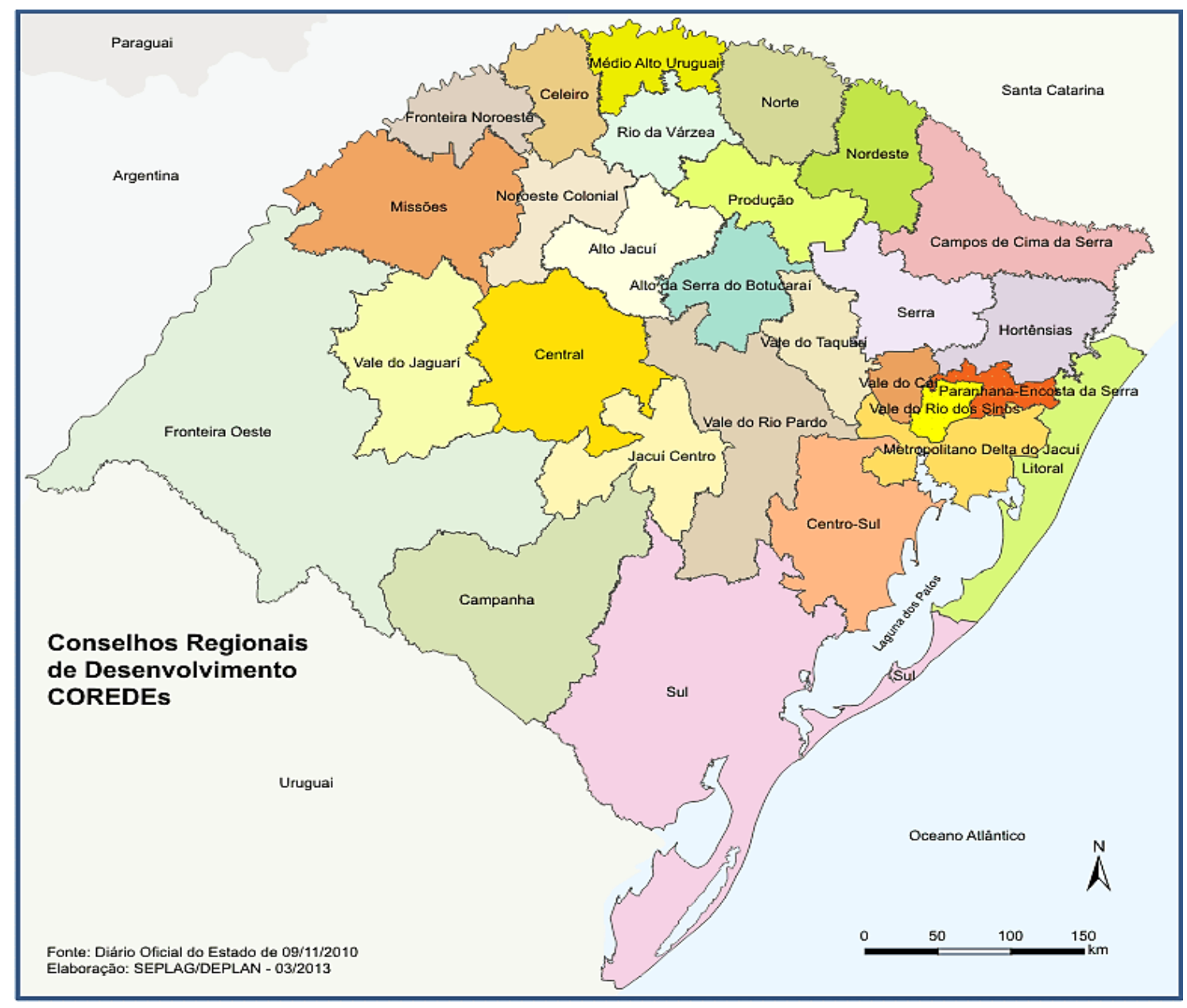

Figura 2.5.1. Os Conselhos Regionais de Desenvolvimento do RS.

Fonte: SEPLAG/DEPLAN, 2013.

Atinente à atividade industrial, o modelo de inserção na economia nacional assumido pelo Rio Grande do Sul a partir dos anos de 1960, que transferia para as indústrias do Sudeste do país o processamento final dos produtos destinados ao consumo e exportação, foi um fator agravante da crise vivida na região, que posteriormente, na década de 1980, atrelou a economia estadual (e consequentemente a local) às flutuações cíclicas da economia nacional. Em função do enfraquecimento financeiro, uma parcela considerável do empresariado da indústria local deixa de deter o controle acionário de seu empreendimento em detrimento de grupos multinacionais (ROTTA, 1999; CARRION JR., 1986).

Através de estímulos e financiamentos públicos, o Governo Federal colabora para que as empresas multinacionais ocupem o mercado brasileiro, processo esse que teve dois momentos distintos: o primeiro, correspondente à entrada maciça de empresas estrangeiras em novos empreendimentos, o que ocorre entre os anos de 1955 e 1962, e o 
segundo, posterior, que se estende até o início da década de 1970, quando parte significativa do antigo parque industrial nacional tem seu controle acionário pouco a pouco transferido para o capital externo (CARRION JR., 1981, p. 37).

Em âmbito local, quando precisou adquirir novos equipamentos e tecnologias para permanecer no mercado, o setor industrial da Fronteira Noroeste ampliou a dependência em relação ao mercado financeiro, ou buscou parceria com grupos industriais multinacionais, como por exemplo, o Frigorífico Prenda, a Ideal Máquinas Agrícolas e a Elegê Alimentos, de Santa Rosa, e a SLC, de Horizontina. A parceria significou, gradativamente, a transferência do controle acionário das empresas locais para os grupos multinacionais parceiros (ROTTA; DALLABRIDA, 2007, p. 48).

Ainda nos anos de 1970, um diagnóstico elaborado por uma equipe da Universidade Federal do Rio Grande do Sul (UFRGS), a pedido de lideranças locais, evidenciou que havia uma restrição que limitava o crescimento da economia regional, esta apontou que a minifundiarização gerava baixa produtividade agrícola, insuficiência de renda familiar, evasão da população rural e outras consequências. Daí que as alternativas apontadas pelo conjunto da sociedade direcionaram para a modernização da agricultura, buscando agregar maior valor aos produtos por via da agroindustrialização (ROTTA, 1999, pp. 82-83).

Na definição de Lauschner (1993) agroindústria é "a unidade que transforma o produto agropecuário originário da atividade primária natural ou manufaturada para sua utilização intermediária ou final". Vista por esse prisma, uma indústria moveleira é considerada uma agroindústria, assim como uma indústria calçadista, um frigorífico, um moinho, uma panificadora, pertencem enfim à agroindústria todas as atividades que envolvem produtos originários da atividade agrícola e pecuária.

Nos estudos de Lauschner (1993) e Batalha (2001), surge o conceito de agronegócio ou agribusiness introduzido por Davis e Goldberg (1957), que definem o complexo rural como operações pertinentes às atividades de produção e distribuição de insumos rurais, de exploração rural, armazenamento, processamento e distribuição dos produtos agrícolas e de seus subprodutos, de forma que estes fatores estão diretamente inter-relacionados em forma de cadeia produtiva.

Montoya (2002) entende que o termo agronegócio foi oficializado no Brasil na década de 1990, como tradução de agribusiness, que até então sofria uma série de conotações econômicas, dependendo do uso que lhe era dado. Entre as inúmeras traduções e derivações, variava desde sistema agroindustrial, complexo agroindustrial, 
negócios agrícolas e alimentares, complexo rural e agroindustrial, além de economia da alimentação, complexo agrário e complexo agrícola.

O agronegócio da Região Fronteira Noroeste do Estado do Rio Grande do Sul contempla as agroindústrias tais como os complexos agroindustriais de empresas públicas e privadas, como moinhos, cerealistas, frigoríficos e abatedouros (de aves, suínos e bovinos); agroindústrias de derivados de leite (beneficiamento e industrialização); agroindústrias de conservas (doces, geleias, condimentos e picles); agroindústrias de vinhos, sucos, aguardente e derivados de cana-de-açúcar (ZUCATO et. al, 2010, p. 106). Estão também presentes, com forte atuação na região, outras indústrias consideradas no agribusiness ao longo da cadeia produtiva do agronegócio, como as de vestuário, moveleira (mobiliário) e a metalmecânica.

A opção pela modernização da agricultura e pela agroindustrialização viabilizou a formação de um conjunto de indústrias atualmente bem sucedidas, e estas por sua vez viabilizaram aquelas. De um lado, as indústrias transformadoras de produtos gerados pela agropecuária regional e, de outro, o setor de máquinas e implementos agrícolas e os insumos. Se é verdade que a indústria transformadora esteve presente na base da industrialização brasileira, em Santa Rosa município polo da Região Fronteira Noroeste, ela é a prova de sua vitalidade e permanência. 


\section{REGIONALIDADES}

\subsection{REGIÃO}

As variadas interpretações sobre o conceito de região dificultam a aproximação em torno de um significado que satisfaça as diversas áreas afins. A definição envolvendo o termo região deve ser dinâmica e flexível, pois as estruturas que definem e condicionam as dimensões de região são vulneráveis ao tempo e mudam muito frequentemente.

Para Moreira e da Costa (1995, p. 105) pode-se reconhecer o termo região como o produto da ação da sociedade e de seu sistema econômico sobre o espaço. Assim, a região é um subespaço de uma totalidade, onde o econômico tem preponderância na organização geográfica. No caso do modo de produção capitalista, apesar de sua tendência de homogeneização espacial, fazendo desaparecer as "regiões", estas podem ser identificadas a partir da desigualdade com que se processa a reprodução e acumulação do capital.

O conceito e a definição de região são também utilizados de forma distinta em outras áreas do conhecimento. Economistas, por exemplo, também se envolveram em estudos regionais. Para Ferreira (1989), a análise regional se preocupa com os agrupamentos ou aglomerações das atividades econômicas, sociais, políticas e administrativas. A atenção está voltada para o estudo das diferenciações e das interrelações de áreas de um universo, onde os recursos são distribuídos de maneira desigual.

Segundo Maciel (1995, pp.171-173), diversas referências permitem "a cada região se conhecer e ser reconhecida":

Região, de forma ou de outra, remete a um espaço determinado, porém, este espaço é social e culturalmente construído através de um processo histórico - o que faz com que a região seja fruto de relações sociais estabelecidas num determinado território.

O processo de ocupação social da região, os aspectos culturais, políticos, étnicos e históricos são estudados com bastante afinco, conforme salienta Breitbach (1998). A dinâmica social, os grupos étnicos, a mobilidade social, a dinâmica econômica, os principais produtos econômicos, a matriz fundiária e produtiva, a participação dos setores produtivos, a dinâmica das relações políticas locais, regionais e sua interação nacional, são alvos de estudos recentes. 
A Região Noroeste que apresenta uma economia funcional ajustada à proposta federal enfrentou vários desafios na reconstrução do atual padrão de estrutura econômica. Se a agricultura é funcional ao polo dinâmico que é o setor industrial, conforme Bressan, (1978, p. 257), cabe à região a responsabilidade sobre a perspectiva do almejado desenvolvimento.

Enquanto resultado da interação dos diferentes grupos sociais e também da supremacia de alguns grupos no direcionamento dos aspectos políticos, econômicos, sociais e culturais, o Noroeste do RS constrói sua recente história.

\subsection{DISPARIDADES REGIONAIS BRASILEIRAS}

Os desequilíbrios regionais, agravados com o advento da globalização, dificultaram as tentativas de uma regionalização condizente com as aspirações de todas as áreas do conhecimento. Ao invés de provocar a homogeneização, a globalização favoreceu um desenvolvimento espacialmente desigual e consequentemente ampliou as diferenças entre as regiões, de um mesmo país ou estado, aumentando as disparidades entre elas e a competição (DINIZ, 2000).

Conforme Haddad (1993, pp. 255-270), as regiões são propostas a partir dos movimentos de diferenciação econômica gerados pela difusão do capital no espaço. Segundo ele, uma região não é, pura e simplesmente, a manifestação local da economia nacional. Toda região mantém características específicas e possui identidade própria, por isso necessita de teorias próprias e específicas para explicar o processo singular de seu desenvolvimento.

A existência de abismos socioeconômicos entre as Grandes Regiões sempre foi muito pronunciada na história econômica brasileira. Até o início do século $\mathrm{XX}$, a economia brasileira tinha dois sistemas de produção principais, um localizado no Nordeste, que tinha a produção e a exportação de açúcar como base principal na geração de renda, e o outro localizado no Sudeste, que tinha como principais produtos o açúcar, próximo ao Rio de Janeiro, os minerais, principalmente a extração de ouro, além da produção de couro, carne bovina e, em menor medida, café.

A ocupação territorial nordestina incluía também áreas dedicadas à produção de bens de consumo para a população que vivia nas regiões produtoras de açúcar, assim como alguns de seus insumos e mesmo bens de capital, como era o caso de alguns 
animais usados no processo de produção. A ocupação territorial central localizava-se no Rio de Janeiro e em Minas Gerais, mas já incluía ocupações em São Paulo e na Região Sul, esta dedicada à produção de alimentos e insumos para os principais polos de produção para exportação (BARROS, 2011, p. 53).

Boa parte das atividades econômicas necessárias para satisfazer as demandas de consumo da sociedade na economia mineira do SE era realizada sob maior divisão do trabalho do que no NE açucareiro. Isso assegurava maior produtividade pela especialização e a utilização mais eficiente de recursos que geravam custos fixos, com instalações prediais e mecanismos de controle, podendo fazer com que o PIB per capita no Rio de Janeiro e em Minas Gerais fosse mais elevado do que em Pernambuco e Bahia, que eram os maiores polos econômicos nordestinos naqueles tempos. Dentro de um raciocínio econômico, pode-se dizer que a maior divisão do trabalho no polo mineiro assegurava maior multiplicador das exportações na Região Sudeste (BARROS, 2011, pp. 53-54).

A presença da Corte de Portugal no RJ passou a direcionar boa parte dos impostos arrecadados em todas as regiões para serem gastos no Sudeste, fomentando uma série de atividades econômicas de comércio e serviços, e até mesmo de pequenas indústrias nessa região, de forma que o valor agregado per capita de renda se elevou muito em comparação às demais regiões. Quinze anos depois da chegada da Corte, a arrecadação tributária das províncias localizadas no Centro-Sul era de quase o dobro das províncias do Nordeste (BARROS, 2011; FURTADO, 2010).

Entre 1822 e 1889, não houve grandes incentivos para migrações entre as regiões Nordeste e Centro-Sul ou os desequilíbrios entre elas na atração de imigrantes. Enquanto a população do NE teve um crescimento médio anual de 1,91\% entre 1819 e 1872, a do Sudeste cresceu 1,94\% no mesmo período. Porém, um fato chama atenção: o crescimento da população do Sul foi bem superior ao verificado no NE e SE. O Sul cresceu 2,49\% no período imperial. Isso decorre de um início de colonização da região por europeus que buscavam uma nova pátria em que pudessem ter vida semelhante àquela com que sonhavam em seu continente de origem. Esses indivíduos vinham em busca de regiões com terras gratuitas ou de baixo custo e condições climáticas semelhantes à europeia (BARROS, 2011, p. 62).

A hipótese de Celso Furtado para explicar as desigualdades regionais fundamenta-se na teoria utilizada por Raul Prebisch (cf. CEPAL), que ganhou evidência em 1949 ao explicar o atraso relativo da América Latina. Furtado, que faz parte do 
grupo seleto de intelectuais estruturalistas, parte do pressuposto de que regiões dedicadas a atividades primárias exportadoras têm seu crescimento limitado, haja vista que seus ganhos de produtividade são exportados, uma vez que houve redução do preço de seus produtos em decorrência da competição em seus mercados. Não obstante, produtos industrializados não sofrem desse problema, pois os sindicatos e as empresas com poder de mercado retêm os ganhos de produtividade como renda adicional dos agentes envolvidos nesses setores. Essa assimetria de comportamento dos preços gera deterioração dos termos de troca das mercadorias primárias, que são aquelas nas quais os países menos desenvolvidos são especializados no comércio internacional (BARROS, 2011, p. 100).

Os estruturalistas argumentam que, na prática, a partir de um dado momento, após uma economia primário-exportadora atingir certo nível de complexidade, o consumo interno pode começar a sofrer pelo estrangulamento da capacidade de importar. Nessas circunstâncias surgem as primeiras indústrias locais, que geram demanda para justificar novas indústrias e, assim, gerar um círculo virtuoso em que as economias de capitalismo tardio começam a se industrializar. Esse processo gera maior capacidade de reter os ganhos internos de produtividade, e, com isso, elevar o bem-estar interno, sem exportar os ganhos realizados (BARROS, 2011, pp. 100-101).

O Brasil encontrou-se na situação de estrangulamento de seu consumo nos momentos de crise dos preços do café no final do século XIX e nas décadas iniciais do século XX (BAER, 1983; FISHLOW, 1977; FURTADO, 2010). A renda interna caía por causa da queda dos preços do café, mas a elite local não reduzia seu padrão de consumo na mesma proporção que seus lucros caíam; ao contrário, ela consumia o próprio estoque de riqueza para manter o consumo, gerando, dessa forma, um estrangulamento na oferta interna de bens de consumo de luxo, boa parte deles de produtos industriais, por conta dos limites da capacidade de importar. Assim, criam as condições estruturais para o desenvolvimento da indústria no País, através da substituição de importações (BAER, 1983; BARROS, 2011; FURTADO, 2010; SUNKEL, 2000).

Parte do consumo das populações passou a ser suprido com bens produzidos domesticamente, a partir de indústrias surgidas àquela época, início do século passado (BAER, 1986, BARROS, 2011; FISHLOW, 1977). Naquele período, a maior parte dos indivíduos que demandavam produtos industriais vivia no Sudeste, especialmente em São Paulo e no Rio de Janeiro, porque aí se encontrava o maior polo produtor de bens 
primários exportados e sede do governo central (BARROS, 2011, CANO, 1977; FURTADO, 2010).

A partir das primeiras décadas do século XX, já consolidada a superioridade do SE, sua indústria continuava a crescer e a ganhar escala, de forma que se tornou suficientemente competitiva para limitar o potencial de desenvolvimento industrial nas demais regiões. Seus ganhos de escala eram tais que, mesmo com os custos dos transportes, seus produtos chagavam a preços competitivos em outras regiões. Desse modo, a possibilidade de surgimento de indústrias locais ficou limitada e isso, de certa forma, cristalizava as desigualdades regionais surgidas a partir do processo de industrialização.

Entre as décadas finais do século XIX e as primeiras décadas do XX, na época em que o café era o principal produto de exportação brasileiro, de acordo com esse período econômico, ao se desenvolver industrialmente, o Sudeste gerava grandes cidades, que aumentavam a demanda por bens primários, seja para a alimentação ou para o processamento industrial. Essa demanda seria mais satisfeita por regiões circunvizinhas, pois os custos de transportes eram menores. Entretanto, quando essas cidades crescem, a demanda aumenta e as regiões mais longínquas têm de ser incorporadas ao sistema produtivo. Essa incorporação teria chegado ao Sul e, por isso, essa região teria se desenvolvido mais rapidamente, tornando-se quase tão desenvolvida quanto o Sudeste (BARROS, 2011, p. 103).

A forte concentração geográfica da produção e da renda em poucas unidades federativas vinha se tornando um fato real antes mesmo do final do século XIX, até que se intensificou ainda mais a partir da década de 1950, período que consolidou definitivamente o Sudeste do País como o maior polo econômico nacional (CANO, 1977; CARRION JR. 1986; DINIZ, 1995; SCARLATO, 2001; BARROS, 2011).

O Estado de São Paulo já se destacava pela forte concentração geográfica da produção e da renda, tanto que, posteriormente, mais próximo da década de 1970, este participava com 39\% da renda nacional, apesar de representar apenas 2,9\% do território brasileiro. As diferenciações na renda per capita geradas por aquela situação deram origem a fluxos migratórios, que culminaram na concentração populacional ao redor das áreas mais produtivas (DINIZ, 1995, pp. 5-6).

A movimentação da fronteira agrícola para o Sul do Brasil na década de 1940 e 1950 iniciou uma acanhada desconcentração da produção tanto que, em um período posterior, entre as décadas de 1970 e 1980, a industrialização brasileira iniciou a volta 
do seu processo de concentração regional que se mantinha desde seu surgimento (CANO, 2002; DINIZ, 1995). Isso pode ser percebido analisando a participação percentual das cinco Grandes Regiões Geográficas do Brasil no período entre 1970 e 1990 (Figuras 3.2.1 e 3.2.2). Em 1970, a Região Sudeste participava com 80,8\% da produção industrial brasileira, seguida pela Região Sul, com 12\%, e Nordeste com 5,7\% (Figura 3.2.1).

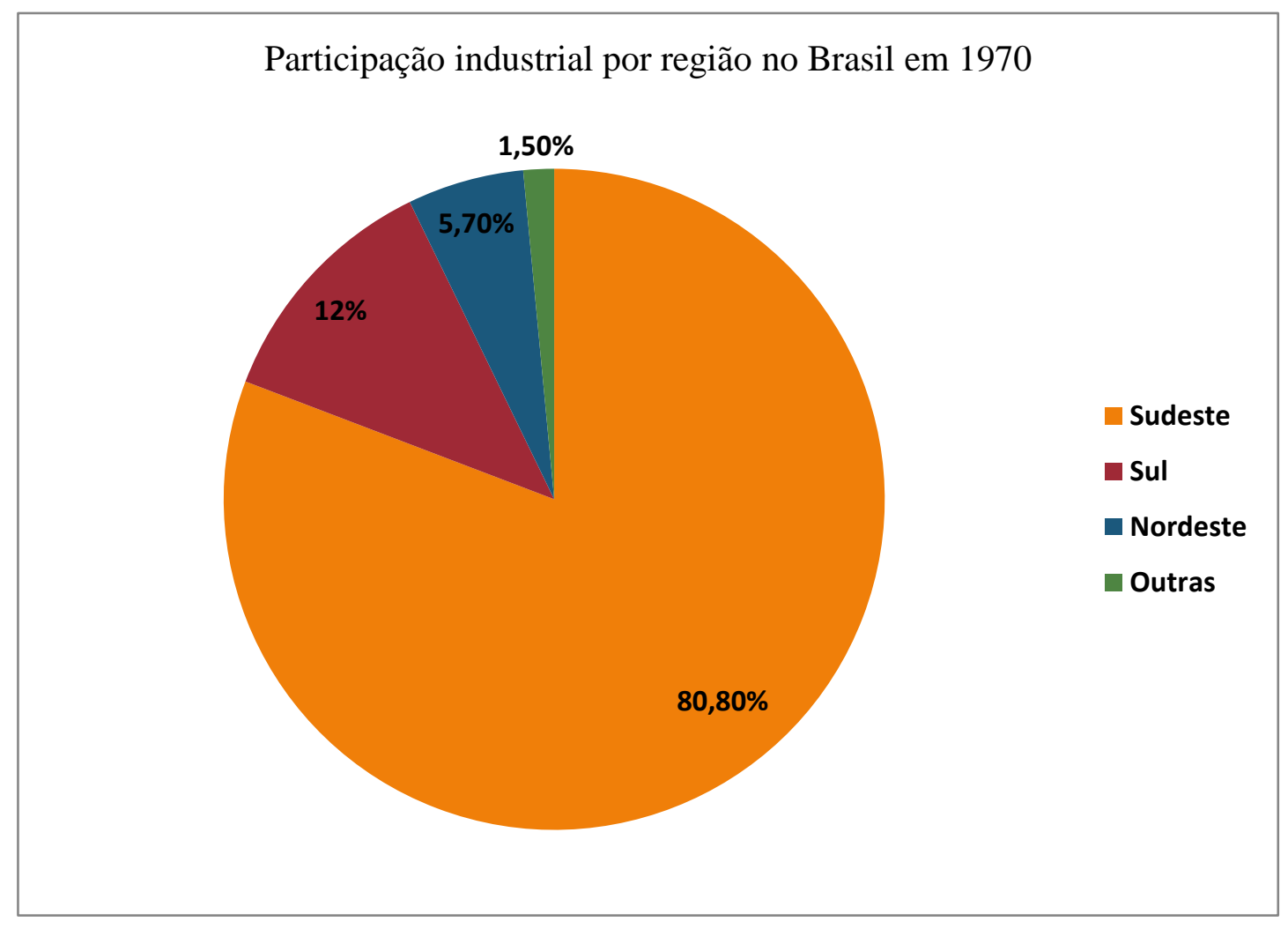

Figura 3.2.1. Participação industrial por regiões no Brasil em 1970.

Fonte: DINIZ (1995, pp. 5-10). 
Processo de reversão de concentração industrial regional em 1990

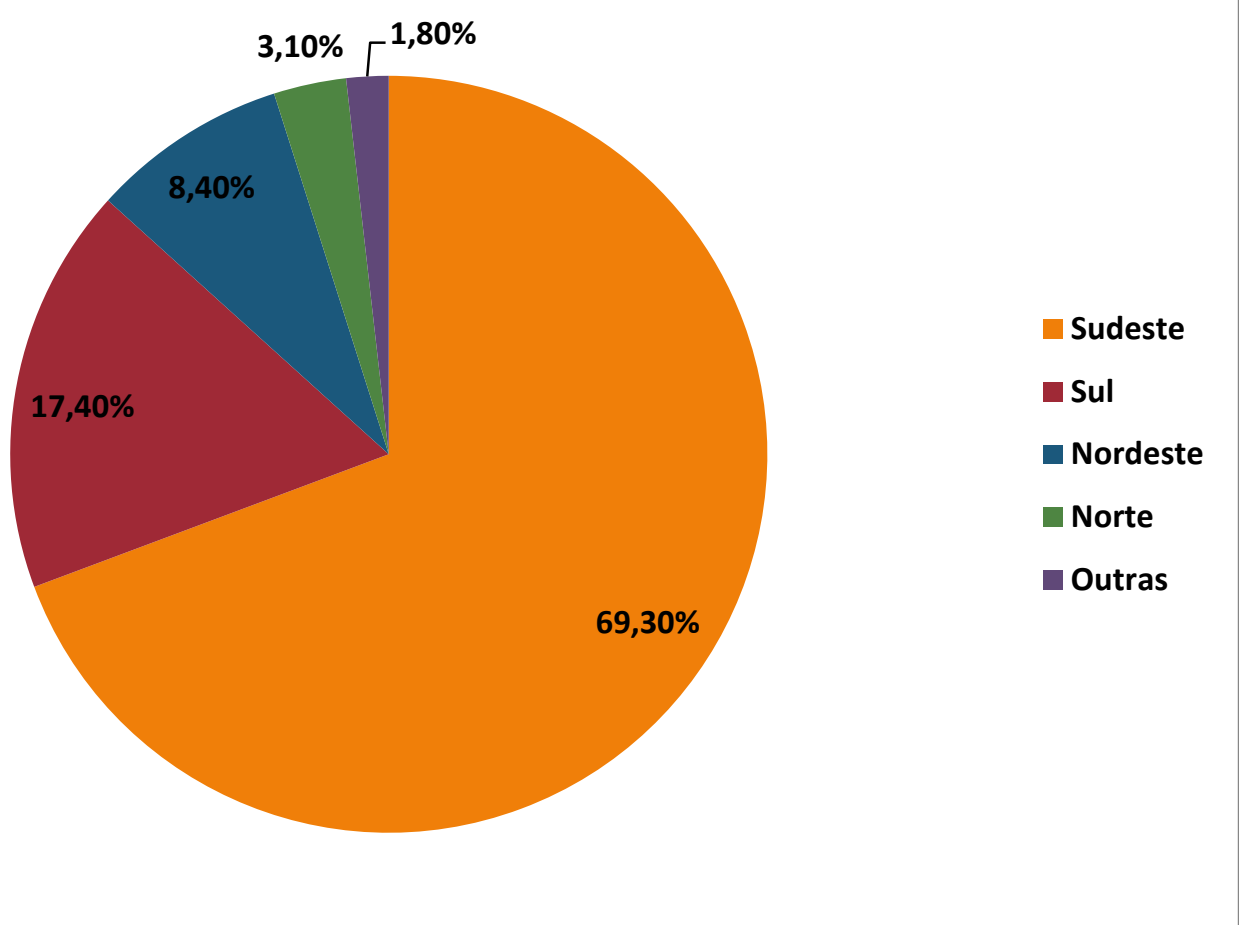

Figura 3.2.2. Processo de reversão de concentração industrial regional em 1990. Fonte: DINIZ (1995, p. 10).

Apesar do dispêndio de esforços, dos investimentos e dos incentivos, a industrialização brasileira tem permanecido relativamente restrita à região Sudeste/Sul, a qual detém $70 \%$ das áreas industriais e mais de $75 \%$ do emprego industrial. A expansão das atividades que mais usam tecnologias tenderia a se aproximar das áreas mais industrializadas, especialmente São Paulo, podendo contemplar a faixa que vai de Belo Horizonte a Porto Alegre (Diniz e Crocco, 1996). A partir do ano de 1985, o processo de desconcentração se reduz e a região tradicional retoma seu dinamismo. São Paulo, em 1995, praticamente recupera sua posição do início dos anos de 1970 e Minas Gerais apresenta ganhos consideráveis.

As outras regiões perdem participação relativa. Em termos de competitividade, o estudo mostra que a região polo brasileira reverte a tendência declinante e destaca inclusive, perspectiva concentradora para o futuro (Azzoni e Ferreira, 1986). Ou seja, mesmo com a desconcentração industrial iniciada no Brasil, o Sudeste permaneceu ostentando a maior participação no bolo industrial brasileiro, e embora a produção tenha se redistribuído para outras regiões brasileiras, a posição e a importância daquela região 
voltam ao seu estado original (Figura 3.2.2). O processo de regresso (reversão) resultou numa participação de 69,3\% do Sudeste em 1990, seguido de 17,4 do Sul, 8,4\% do Nordeste e 3,1\% do Norte (Figura 3.2.2) (DINIZ, 1995, p. 10). Há uma sensível redução de desempenho em torno de 11,5\% do Sudeste no intervalo temporal 1970/1990.

As mudanças ocorridas vislumbram sensível alteração na dimensão espacial do desenvolvimento brasileiro, além da identificação de uma possível continuidade da desconcentração industrial houve também um aumento na heterogeneidade interna das regiões brasileiras (PACHECO, 1999). Isto é, o autor sugere que há o aparecimento de ilhas de produtividade e ressalta a importância crescente das cidades médias e finaliza salientando que há a continuidade da desconcentração em direção ao interior do Estado de São Paulo e os estados do Sul e do Sudeste, especialmente.

O processo de desconcentração produtiva regional do Brasil tem origem nos investimentos estatais oriundos do II Plano Nacional de Desenvolvimento (II PND) (DINIZ, 1995, p. 11). Ou seja, foi uma resposta aos incentivos e investimentos em infraestrutura que ampliaram e unificaram o mercado interno nacional. Isso de certa forma acompanha o processo de expansão da fronteira agrícola como o da soja em novos biomas, direcionada inicialmente em meados do século passado para áreas da Região Sul e posteriormente, 1970/2006 (Figura 3.2.3) para o Cerrado, na Região Centro-Oeste e, num último momento, para o Norte e Nordeste brasileiro.

Até meados dos anos de 1970, com a implantação do parque tecnológico concentrado na Região Sudeste, ficavam consolidadas as desigualdades entre as regiões brasileiras. Ao serem observadas a qualidade de vida da população, o PIB e a concentração industrial, pode-se construir um perfil das regiões mais desenvolvidas, assim como aquelas mais deprimidas. O perfil heterogêneo obrigou o Governo Federal a investir no chamado planejamento regional, visando reduzir as disparidades interregionais. Para isso foram criados órgãos voltados às macrorregiões brasileiras como a SUDENE, a SUDAM, a SUDECO e a SUDESUL, esta última abrangendo os estados do Paraná, de Santa Catarina e do Rio Grande do Sul (DINIZ, 1995; 2000). No Sul também foi fundada uma autarquia interestadual fomentadora, o Banco Regional de Desenvolvimento do Extremo Sul - BRDE.

Os desequilíbrios regionais segundo Scarlato (2001) são resultantes da posição ocupada pelo Brasil no interior da nova divisão internacional do trabalho que se configurou entre as economias desenvolvidas e alguns países menos desenvolvidos industrializados, principalmente, depois dos anos de 1960, e explica o fato de que a 
industrialização acelerada no período não conseguiu tirá-lo do subdesenvolvimento e tampouco diminuiu suas disparidades regionais. $\mathrm{O}$ modo como se deu a industrialização brasileira acabou acirrando ainda mais as desigualdades e concentrando a indústria no eixo Rio de Janeiro - São Paulo - Belo Horizonte e Porto Alegre, as quatro maiores regiões metropolitanas.

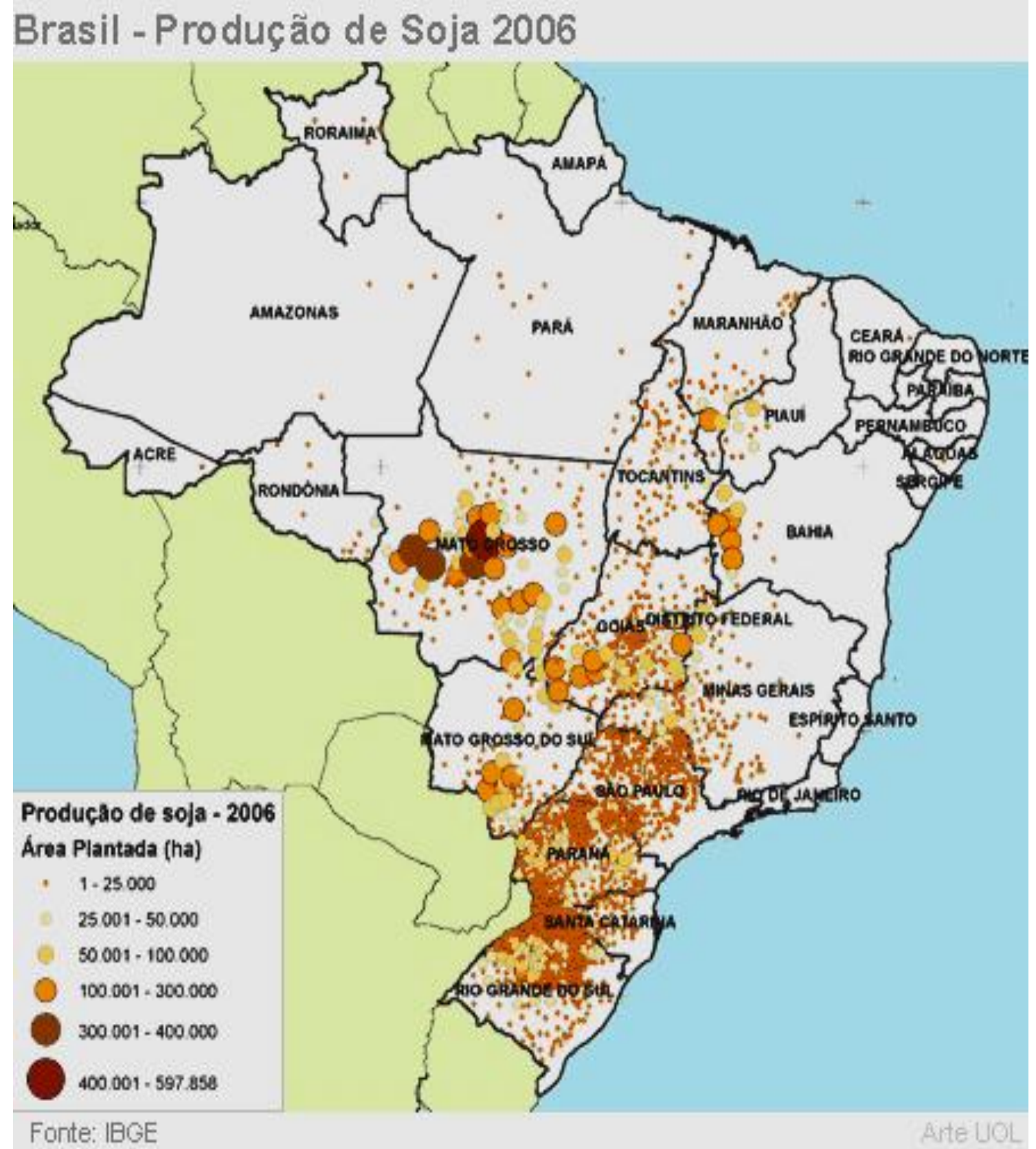

Figura 3.2.3. Distribuição e produção da soja no Brasil, área plantada (ha) em 2006. Fonte: IBGE, 2013. 


\subsection{DISPARIDADES REGIONAIS NO RIO GRANDE DO SUL}

É de supor que as conhecidas diferenciações econômicas regionais do território nacional incluam o Estado do Rio Grande do Sul, desde o início do processo de ocupação de seu território. A unidade gaúcha reconhece áreas internas que apresentam diferentes graus de dinamismo econômico e feições particulares de inserção no sistema de produção. As diferenciações regionais desse Estado - de estruturas, funções e formas específicas- configuram áreas que, se não são dotadas de verdadeira identidade regional, ao menos assumem uma posição própria, frente a interesses externos advindos tanto do Estado e do País como do Exterior.

Em qualquer nível de análise encontra-se a combinação de desigualdades, nas quais convivem lado a lado espaços pobres e ricos, deprimidos e dinâmicos. Algumas regiões do Estado podem ser colocadas no padrão de primeiro mundo como, por exemplo, o nordeste do RS, e há outras que podem ser qualificadas, segundo o índice de desenvolvimento humano, como carentes, tal como a mesorregião Noroeste, onde, ao lado de microrregiões com desenvolvimento superior à média do Estado existem focos de extrema pobreza, com PIB per capita abaixo de 500 dólares (PRÓ-RS, 2010).

Para melhor ilustrar os desequilíbrios regionais do RS é esboçada uma divisão regional no Estado nos moldes propostos por Bertha Becker para o Brasil, já em 1972, e retomada recentemente pela IBGE (Figura 3.3.1), essa regionalização se caracteriza do seguinte modo: a) o centro irradiador e concomitantemente concentrador, tratando-se da área metropolitana de Porto Alegre, cuja influência estende-se até o oeste e o sul de Santa Catarina; b) periferia dinâmica, constituída pela área imediatamente ao norte da metrópole e por sua circunvizinhança; c) a periferia de crescimento lento, maior região gaúcha em termos de superfície, dividindo-se em dois subespaços: a região latifundiária e a região de médias e pequenas propriedades; e d) periferia deprimida ou de crescimento nulo (MOREIRA; COSTA, 1995, p. 105).

O centro irradiador compreende a região metropolitana de Porto Alegre, a metrópole estadual, cuja importância se acentua cada vez mais no espaço do RS e mesmo fora dele, uma vez que a influência de Porto Alegre se estende até o oeste e o sul de Santa Catarina. A partir do centro irradiador que se difundem as inovações e se decidem os investimentos de maior quantia, normalmente, em benefício da própria 
concentração econômica local. Apesar disso, seu dinamismo em comparação às demais regiões, comandado pela industrialização, possui uma periferia pobre, e por cidadesdormitório, estas cada vez mais pobres, com índices de desenvolvimento humano médio-baixo como o município de Alvorada.

Por sua vez, a área conhecida como periferia dinâmica localiza-se na área logo ao norte da metrópole e por sua circunvizinhança. Nessa região estão contidas o chamado cinturão verde de Porto Alegre, onde pequenos agricultores se dedicam a extração leiteira e à hortifruticultura e a parte da zona colonial mais antiga, de descendência de alemães (Nova Petrópolis) e de italianos, centralizada pela área urbano industrial de Caxias do Sul e Bento Gonçalves. Mesmo tendo havido ao longo dos tempos fracionamento dos lotes rurais, tem-se chegado a uma considerável produtividade agrícola. Todavia, o segmento industrial mais dinâmico nessa região é o metalúrgico mecânico, responsável pelo grande afluxo de capital e de população para os seus maiores municípios.

A região da periferia de crescimento lento inclui em seu bojo o Noroeste do Estado, representada pelo número 3, como identifica a Figura 3.3.1. Ela é tida como a maior região do Estado em superfície, subdividindo-se em dois espaços, cada qual com sua base econômica: a região latifundiária predominantemente pastoril, representada pela "fronteira" ou Campanha gaúcha (1 e 2) e partes do planalto médio, e a região de predomínio de médias e pequenas propriedades (3), de base agrícola, constituída principalmente por zonas de colonização não deprimidas e por áreas de expansão da empresa rural (alicerçadas no binômio soja-trigo). Apesar de certo crescimento verificado no setor agrícola nas últimas décadas do século XX, também nessa região as cidades funcionam como intermediárias na organização do espaço geográfico, imposta do exterior (MOREIRA; COSTA, 1995, pp. 105-106).

A partir das cidades intermediárias difundem-se a capitalização do campo e a consequente evasão de minifundiários (muitos deles excluídos do sistema produtivo) para fornecerem mão-de-obra às indústrias e serviços urbanos, que se restringem, principalmente, aos ramos ligados à atividade primária. Entre as cidades, destacam-se na zona sul, Pelotas e Rio Grande, essa última mais dinâmica em função do superporto; Santa Maria, exclusivamente no setor de serviços (embora contenha circunvizinhança deprimida) e Santa Cruz do Sul, no Centro; Passo Fundo, Santo Ângelo, Ijuí, Cruz Alta e Santa Rosa, no planalto; e mais isoladas e com menor crescimento Uruguaiana, 
Santana do Livramento, São Borja e Bagé na Campanha (MOREIRA; COSTA, 1995, p. 106).

E, finalmente, os autores salientam a periferia deprimida ou de crescimento quase nulo, correspondente a uma expressiva parcela do espaço rio-grandense que se vê à margem do sistema produtivo, isso devido, em boa medida, ao maior dinamismo da região central e dos núcleos secundários adjacentes. Não podendo ser muito precisa a delimitação das áreas mais deprimidas, pode-se identificar um vasto interior que, ao mesmo tempo em que diminui sua participação no bolo econômico do RS, também perde população. Isso aconteceu nas décadas de 1970 e 1980, em áreas como a Serra do Sudeste, com o centro (exceto Santa Maria), com os Campos de cima da Serra (exceto o nordeste e Soledade), com algumas áreas litorâneas e com grande parte da zona colonial minifundiária do Alto Uruguai (exceto os núcleos de Erechim, mais ao norte e Santa Rosa, a noroeste) (Figura 3.3.1). 


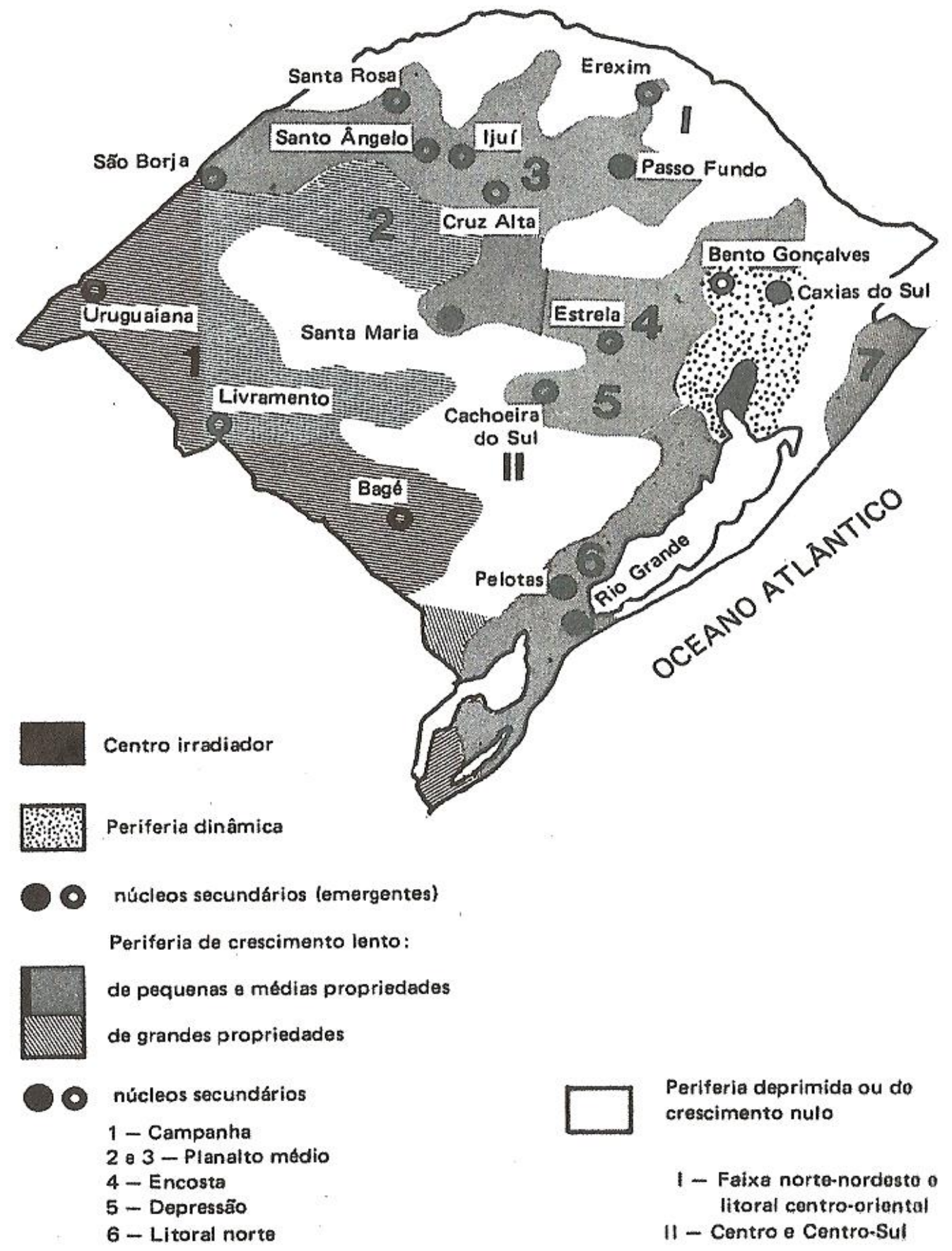

Figura 3.3.1. Um exemplo de regionalização do Rio Grande do Sul. Fonte: Moreira e da Costa (1995, p. 106).

Essa regionalização mostra-se convincente, uma vez que remete a fortes conotações dos desníveis na economia do RS. Conforme aponta Bandeira (2010, pp. 3536), as diferenciações no dinamismo econômico entre as regiões gaúchas persistem e estão presentes ainda nos dias de hoje, podendo ser atribuídas em grande parte aos efeitos das economias de aglomeração acumuladas no Nordeste e Metropolitana do RS. 
Os contundentes efeitos sociais negativos dessas desigualdades podem ser percebidos no cotidiano, normalmente, através dos diversos veículos de comunicação.

No caso de algumas regiões e localidades, o declínio de população foi muito acentuado. Para que se possa fazer uma ideia da intensidade que o fenômeno desse declínio alcançou em certas localidades, como na porção sul do Estado (Bagé, Santana do Livramento, Alegrete e Itaqui), vinte anos atrás se chegou a pensar que essas cidades poderiam ficar sem habitantes antes mesmo da entrada deste século se a média anual de declínio da população permanecesse a mesma. Evidentemente, isso não ocorreu, mas não é impossível que, em algumas décadas, essas e outras áreas venham a ter uma população substancialmente menor do que a da atualidade (BANDEIRA, 2010, p. 37).

O esvaziamento demográfico em algumas áreas do RS resulta da conjunção de dois fenômenos: um deles é a continuidade de emigração em busca de empregos em regiões mais dinâmicas, processo esse cujos efeitos se manifestam, com intensidade variável, desde as primeiras décadas do século XX; o outro fenômeno, mais recente, é a acentuada redução das taxas de fecundidade verificada nas últimas décadas. No Estado essa taxa caiu a menos da metade desde a década de 1960, situando-se em 1,8 filhos por mulher em 2005, conforme dados do IBGE (BANDEIRA, 2010, p. 38). Em 2010 essa taxa decresceu para 1.76 filhos por mulher (IBGE, 2010). Bandeira destaca que a queda de população em certas regiões e municípios resulta do fato de que nelas os novos nascimentos não mais são suficientes para repor o número de pessoal evadido.

O último censo do IBGE apontou o Rio Grande do Sul como o Estado com a menor taxa de crescimento populacional no país. Enquanto na média nacional a população cresceu $1,17 \%$ ao ano na última década, no RS o ritmo foi muito inferior e ficou em apenas 0,49\% ao ano (Figura 3.3.2) no período de 2000 a 2010 (UNISINOS, 2012). O Corede Fronteira Noroeste registrou no mesmo período 2000 a 2010 uma taxa de crescimento populacional menor que 1\% Figura (3.3.3). No município de Santa Rosa, conforme demonstra o mapa da Figura 3.3.2, a taxa de crescimento esteve no intervalo entre $0,01-1,00 \%$, inferior a $1 \%$ ao ano. 


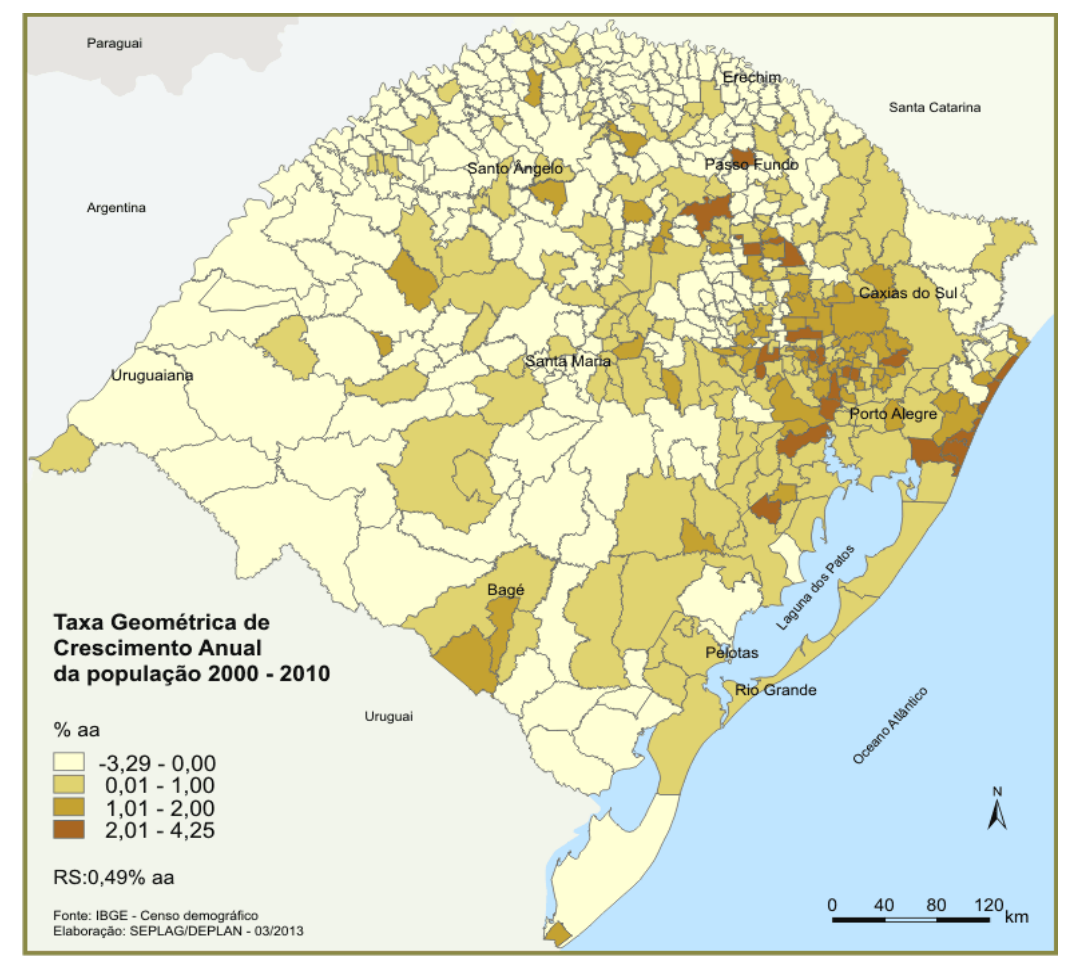

Figura 3.3.2. Taxa de crescimento anual da população nos municípios e no RS entre 2000 e 2010 no RS.

Fonte: IBGE, 2014.

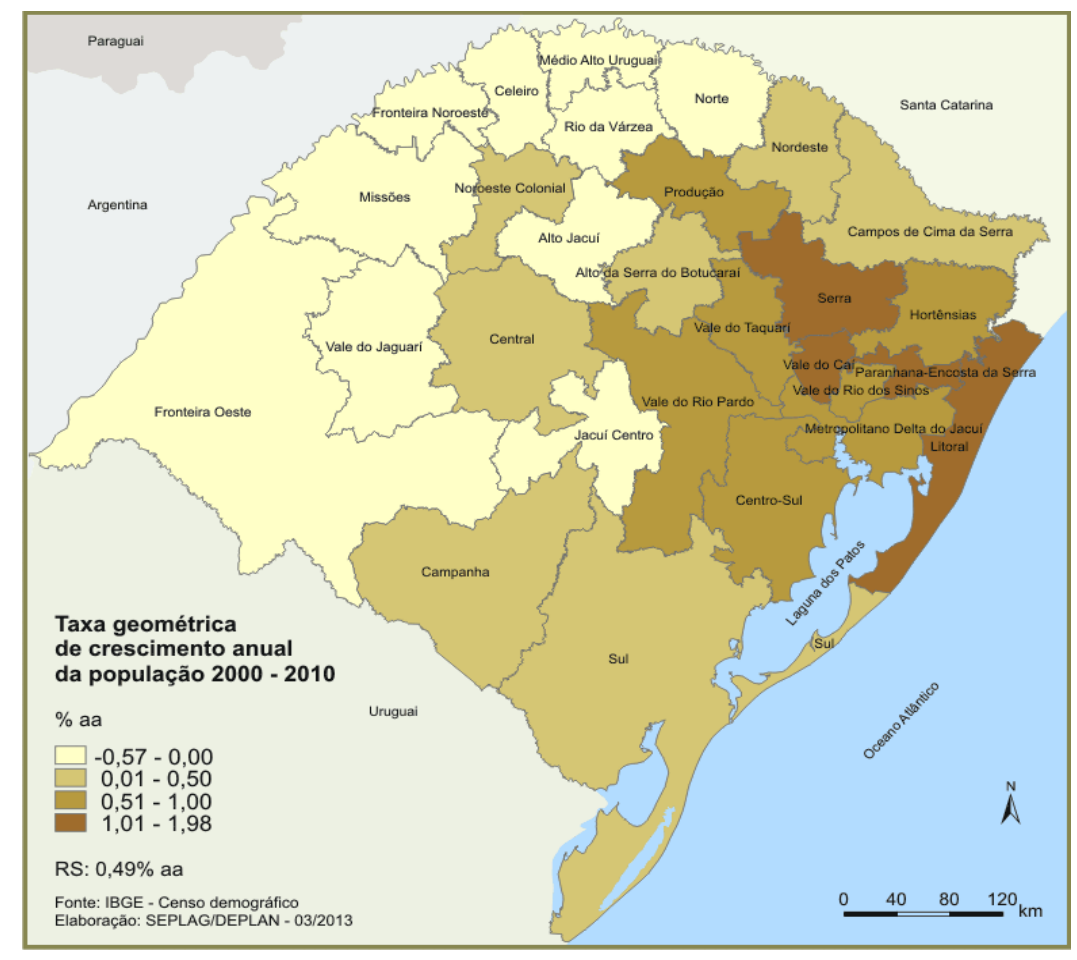

Figura 3.3.3. Taxa de crescimento anual da população dos Coredes entre 2000 e 2010 no RS

Fonte: IBGE, 2014. 
As migrações em busca de novas oportunidades de emprego consistem na maior justificativa às diferenças no dinamismo da economia inter-regionais no RS. Elas podem ser consideradas um fenômeno natural e inerente ao funcionamento de uma economia de mercado. Em alguns casos, essa diferença resulta do efeito das economias de aglomeração sobre a dinâmica locacional das empresas e assim o crescimento econômico tende a ser especialmente concentrado num certo número de localidades. Em outros casos, as migrações ligam-se à abertura de novas oportunidades em áreas de fronteiras agrícolas em expansão, fato esse que fez uma parcela considerável de pessoas, tanto do campo como da cidade, deslocarem-se da região de Santa Rosa para novas áreas, a partir dos anos de 1960 (BANDEIRA, 2010).

A partir da politização do tema das desigualdades regionais gaúchas, o RS pode ser fragmentado em três grandes regiões: Nordeste, Norte e Sul. O rio-grandense Nordeste é a região onde se situam Porto Alegre e as áreas fundadas pelos assentamentos de imigrantes alemães e italianos, no século XIX, precisamente as que alcançaram maior dinamismo econômico nas últimas décadas, com o avanço da industrialização, aumentando sua participação no Produto Interno de 33\% em 1939 para $58 \%$ em 1990. Nessa área teve início a construção de um parque industrial, a começos do século XX, que ocupou o eixo Porto Alegre-Caxias do Sul e paulatinamente suplantou a agricultura, assumindo o papel hegemônico na economia local. Bandeira afirma ainda que as demais regiões gaúchas, Sul e Norte, perderam participação no PIB estadual, caindo a parcela da primeira de 38,3\% para 17,7\% entre 1939 e 1990, enquanto a parcela da segunda reduziu de 28,7\% para 24,3\% (BANDEIRA, 2010, pp. 119-120).

As características socioeconômicas da região Norte do RS foram influenciadas, no final do século XIX e na primeira metade do século $\mathrm{XX}$, por intensos fluxos migratórios oriundos das zonas mais antigas de assentamento de imigrantes europeus, próximas à capital. Tais migrações levaram à ocupação de áreas florestais e ao desmembramento de algumas das grandes propriedades preexistentes dedicadas à pecuária extensiva, fazendo com que passassem a predominar as pequenas e médias propriedades (BANDEIRA, 2010; MANTELLI, 2006). O Norte caracteriza-se também por uma área heterogênea, onde progressivamente se consolidou o predomínio das lavouras de soja, milho e trigo. Algumas de suas cidades conseguiram sediar um crescimento industrial expressivo, em geral diretamente vinculado à produção primária, através do processamento de produtos locais ou da produção de insumos, máquinas e 
implementos agrícolas, como Passo Fundo, Erechim, Ijuí, Santa Rosa e outras (BANDEIRA, 2010).

No RS cerca de $40 \%$ dos movimentos migratórios ocorreu em direção a outros estados do Brasil, com forte ligação com o processo de expansão da fronteira agrícola da soja. No Estado, no entanto, houve um importante movimento migratório para os maiores centros urbanos, no eixo Porto Alegre - Caxias do Sul em busca de oportunidades de emprego no setor industrial e de serviços. Ali houve um crescimento diversificado entre os diferentes ramos industriais, sobretudo na área da indústria de petroquímicos, peças da automobilística, metalmecânica, coureiro-calçadista, dentre outras geradoras de muitos postos de trabalho. Além disso, há um movimento migratório intrarregional, oriundo do meio rural ou das comunidades menores, em direção aos polos urbanos, os quais mantém certo nível de crescimento.

Tomando os Coredes como parâmetro de unidade territorial de análise, Sternberg (2008) admite uma desigualdade de comportamento de regiões do Rio Grande do Sul entre os anos de 1970 a 2000. Uma primeira observação diz respeito à distribuição setorial da ocupação. Em linhas gerais, verifica-se a diminuição do peso do setor primário na ocupação e aumento da participação do secundário e especialmente do terciário, tanto no âmbito de mais de 20 Coredes, como no conjunto do Rio Grande do Sul. A autora admite também o aumento das práticas informais nos anos de 2000, em comparação aos anos de 1970, em todos os setores de atividade, fazendo crescer a proporção de ocupados precários em todos eles, especialmente no setor terciário.

Diante da evolução comportamental das atividades setoriais do RS Lisboa e Bagolin (2008, pp 175-176) admitem que o Estado ficou menos "agrícola" e mais “industrializado". Setores como a indústria de transformação e construção civil, o comércio e prestação de serviços aumentaram significativamente suas participações em detrimento das atividades associadas à agricultura e à extração animal e vegetal. Para tanto, o RS passou por um processo de reestruturação produtiva que teve diferentes impactos entre suas regiões dos Coredes. Os Coredes Vale dos Sinos, Litoral, Metropolitano, Serra, Paranhana e Vale do Rio dos Sinos foram as regiões que mais se beneficiaram no processo reestruturativo produtivo.

$\mathrm{Na}$ atualidade, os Coredes Serra e Vale do Rio dos Sinos apresentam um perfil setorial dinâmico e possuem características específicas que os favorecem em termos de crescimento; o Corede Metropolitano tem uma composição setorial é dinâmica suficiente para promover seu crescimento mesmo não dispondo características 
específicas que promovam seu crescimento. Os três Coredes em 1970 concentravam cerca de $30 \%$ da população frente aos $42 \%$ nos anos de 2000. Fundamentalmente os Coredes Metropolitano, Serra e Vale do Rio dos Sinos fazem parte da área mais industrializada do Rio Grande do Sul, além de concentrar metade da renda e da população.

Algumas áreas rio-grandenses, com o passar dos tempos, estagnaram economicamente, andaram em passos lentos, outras, porém, passaram a se desenvolver ainda mais, atraindo para elas mais diversidade de investimentos. $\mathrm{O}$ certo é que as regiões mais desenvolvidas no Estado do RS estão diretamente associadas às primeiras zonas de colonização e desenvolvimento que remontam aos séculos XVIII, XIX e XX, e as demais, mesmo com o passar dos tempos, ainda não se equipararam àquelas, por diversas razões.

A ocupação da microrregião da Grande Santa Rosa (Corede Fronteira Noroeste) foi feita essencialmente por colonos descendentes de imigrantes vindos da Europa. Eles inicialmente desenvolveram atividades de subsistência, procurando, na medida do possível, consolidar o estabelecimento físico de suas famílias, de diferentes etnias, em diferentes localidades da referida região. Com o advento da modernização da agricultura, em meados do século XX, o processo produtivo destas famílias de colonos se modificou. Passou-se à produção de grãos em larga escala, particularmente do trigo e soja, ficando as culturas de subsistência pouco a pouco jogadas à margem das prioridades locais.

A característica populacional configurou a região em torno de propriedades de pequeno e médio porte (maioria até 50 ha), fato que as leva a manterem um sistema diversificado de produção visando, particularmente, ao abastecimento local/regional/estadual, enquanto o trigo e a soja passaram a ser os elementos motores de uma economia modernizadora. Esse processo foi viável nos anos finais da década de 1960 até finais dos anos de 1970, graças à marcante presença do Estado, na medida em que oferecia subsídios e um protecionismo a essas culturas (BRUM et al., 2008, p. 142).

A dinâmica populacional da Fronteira Noroeste parece ser muito comum a outras microrregiões no contexto à mesorregião Noroeste do RS. Tais semelhanças iniciam-se desde a primeira fase que se caracteriza pela ocupação e povoamento, que vai até os anos de 1950/60, em que há um crescimento da população, especialmente a rural, intensificado pelo movimento de imigração dos colonos. A segunda fase estendese até os anos de 1980 e se caracteriza pela redução do ritmo de crescimento da 
população e pela acelerada urbanização. A terceira fase compreende os últimos 20 anos, em que ocorre um decréscimo da população da região, fruto da intensa emigração de pessoas em busca de oportunidades de trabalho e renda (BRUM et al,. 2008, p. 145). O Corede Fronteira Noroeste registrou, em 2010, população absoluta de pouco mais 210.000 (intervalo 150.001-300.000) habitantes como evidencia a Figura 3.3.4 (IBGE, 2014).

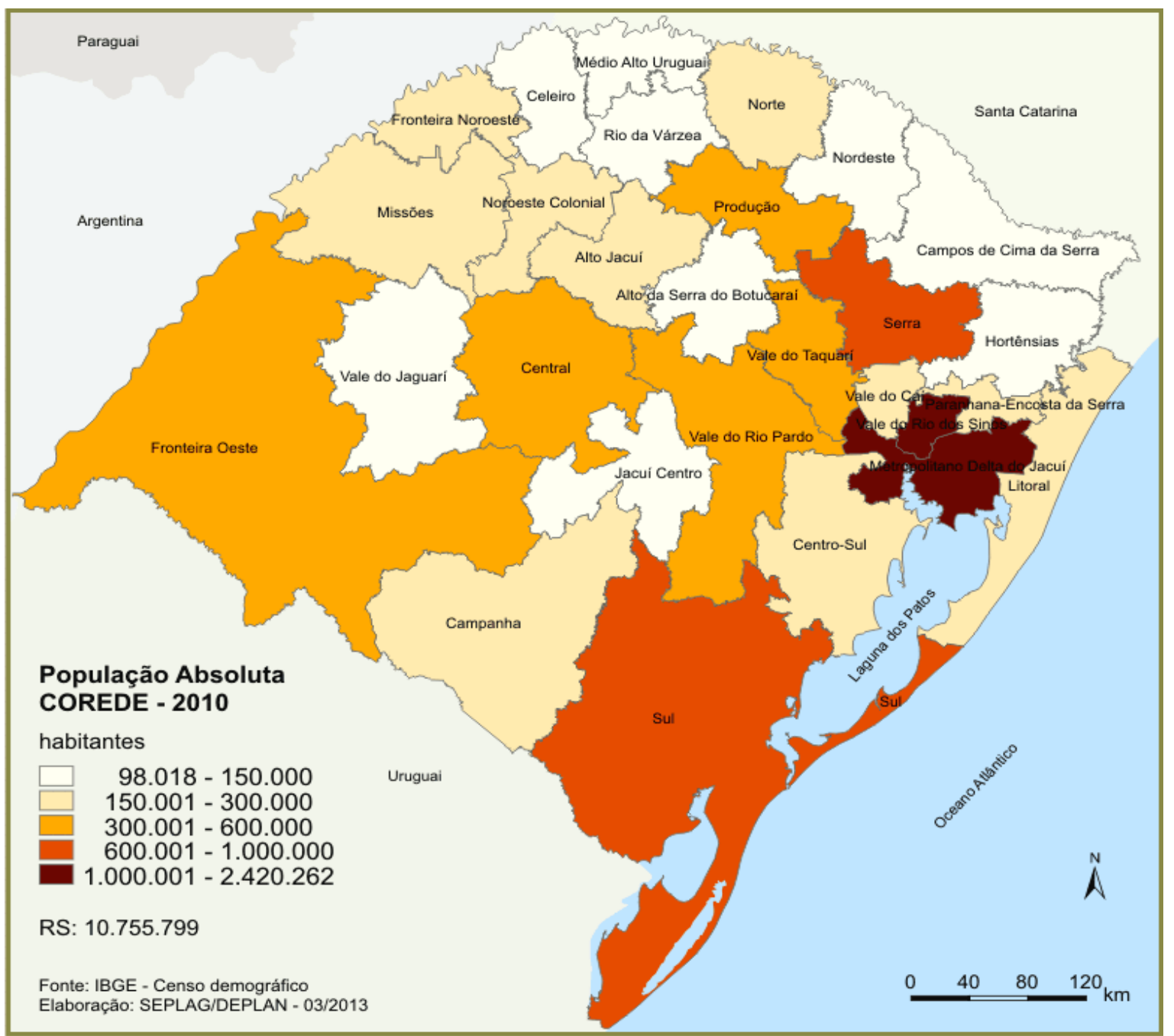

Figura 3.3.4. População absoluta por Corede em 2010

Fonte: IBGE - Censo demográfico, 2014

No Corede Fronteira Noroeste, outros municípios como Três de Maio, Horizontina e Santo Cristo também passaram a representar polos microrregionais de concentração de atividades dos três setores da economia que deram suporte a uma nova realidade e passaram atrair a população que começava a sobrar no meio rural, uma vez que a mesma buscava nova oportunidade nas cidades. 


\subsubsection{Arranjos de governança microrregional}

Pelos quatro cantos do País manifestam-se buscas de caminhos para revitalizar as economias locais, motivo da recente proliferação de várias formas de articulação política com ambição de construir arranjos de governança microrregional. Alguns argumentos buscam as justificativas por articulações que promovam construir arranjos governamentais. Segundo Veiga (2006) os arranjos governamentais de caráter microrregional podem ser vistos como decorrências inevitáveis da óbvia incapacidade de uma simples estrutura do tipo União/Estados/Municípios democratizar uma sociedade que objetivamente se organiza em uma dúzia de imensas cidades metropolitanas, rodeadas por 160 microrregiões polarizadas e dominadas por aglomerações urbanas ou cidades, e por uma imensa variedade de situações que ocorrem em 390 microrregiões rurais. Tais arranjos institucionais visam a gerar governança, justamente onde mais fica clara a debilidade governamental, ou a quase falta completa de governo. E nos locais do Brasil em que já houve mais desenvolvimento (Sul/Sudeste), essa debilidade ou falta de governo vem se manifestando com mais clareza nos vazios institucionais que se situam entre a base, o poder municipal e o escalão intermediário, o estadual.

O Rio Grande do Sul apresenta grande diversidade interna, seja de cunho sócioeconômico ou natural. Diversos estudos técnicos produzidos ao longo de décadas reconheceram regionalizações internas no Estado ou mesmo a existência de microrregiões específicas e com desiguais ritmos de desenvolvimento. No entanto, a partir da década de 1980, a região buscou construir alternativas próprias, pois a União havia retirado em grande parte seu apoio ao processo modernizador das unidades da Federação.

A partir dos primeiros anos da década de 1990, fez-se necessário elaborar um plano emergencial de ações específicas e dirigidas que viesse em socorro daqueles que não podiam e não deveriam abandonar o cenário da economia regional: trabalhadores, agricultores e empresários. Propunha-se o esforço de uma sociedade regional para integrar a luta de todos com vistas a uma melhor representação política em sua organização, promovendo um grande espaço de cooperação e ação conjunta orientada à elaboração de um plano estratégico de desenvolvimento. Os princípios de embasamento do Plano Estratégico de Desenvolvimento (PED) consistiram em somar os esforços da 
região à ação do governo, a partir da vontade política e da qualidade técnica do governo e da sociedade regional.

O PED é fruto de um intenso debate público, realizado ao longo de alguns anos. Nas diversas instâncias da região, tornou-se referência fundamental para as ações do Conselho. Toda a organização interna com o objetivo de motivar as entidades e lideranças para mobilizar forças em prol do desenvolvimento foi feita com base nas definições do Plano e nas articulações externas junto a outros conselhos, órgãos de governo e demais instâncias de poder.

De tal forma que,

o processo de construção do Plano Estratégico de Desenvolvimento foi decisivo para identificar os principais problemas estruturais da região, bem como para apontar os caminhos para seu enfrentamento. As ações instituídas sob a influência do Conselho possuem uma coerência com o diagnóstico, com os objetivos e com as articulações feitas, entretanto os resultados alcançados nem sempre correspondem às expectativas iniciais, o que revela a existência de limites quanto ao alcance de sua atuação (FRANTZ et al., 2008, p. 147).

Dallabrida et al. 2007, p. 75 dizem que:

A nova Constituição do RS, promulgada em 1989, em seus artigos 149, 167, ofereceu o fundamento legal e político à descentralização da administração pública, à ampliação da esfera pública às iniciativas de cooperação em gestão pública, entre a sociedade política e sociedade civil.

Os mesmos autores salientam que o governo do Estado, em 1991, atendendo ao Artigo 55 das disposições constitucionais transitórias, conclamou a sociedade a se organizar em Conselhos Regionais de Desenvolvimento (Coredes) para que pudesse participar indiretamente das ações do governo. O movimento, desde o início, encontrou apoio político nos parlamentares da região junto com o Governo do Estado, apoio técnico das instituições de ensino superior da região, e ainda, incentivo e solidariedade nos órgãos de comunicações, organizações políticas, econômicas e culturais existentes entre os diversos municípios.

“A politização do tema das desigualdades regionais no RS foi um dos principais fatores que abriram espaço para o surgimento e para a continuidade dos Coredes" (BANDEIRA, 2010, p. 119). 
No processo de organização e instituição dos Coredes/RS ocorreu uma ampla mobilização, envolvendo os mais diversos setores da sociedade. Foram arquitetadas regiões a partir de identidades e critérios que levaram em conta experiências de regionalização já existentes. A consolidação de identidades regionais já existentes (como a Região da Grande Santa Rosa) resultou, na ocasião, na criação de 22 Conselhos. Os municípios foram agrupados de acordo com sua proximidade, semelhança quanto às atividades que se dedicam, ao atendimento das necessidades da população, à situação em que se encontram em relação ao meio ambiente e em relação às providências que devem ser tomadas para seu maior desenvolvimento.

Atualmente estão constituídos 28 Coredes (Figura 3.3.1.1) distribuídos entre nove Regiões Funcionais de Planejamento (Figura 3.3.1.2) que têm por objetivo facilitar a regionalização de políticas e órgãos públicos e agregar microrregiões com alguma identidade comum. Tais Regiões Funcionais são intermediárias à unidade estadual e às atuais microrregiões que integram os Coredes.

O Conselho Regional de Desenvolvimento tem foro jurídico na comarca em que reside seu presidente e sede política em todos os municípios que o integram. O funcionamento ocorre através de discussão e deliberação em reuniões plenárias, realizadas em caráter ordinário ou extraordinário, sobre temas de interesse regional. Os Coredes têm como objetivo central

$$
\begin{aligned}
& \text { descentralizar o planejamento e as decisões estratégicas relativas ao } \\
& \text { desenvolvimento de cada região. Com o direito e a responsabilidade } \\
& \text { de definir a alocação de uma parcela dos investimentos previstos no } \\
& \text { orçamento do Governo do Estado, os Corede foram desafiados a } \\
& \text { construir uma identidade regional, elaborar diagnósticos } \\
& \text { socioeconômicos, estabelecer diretrizes de desenvolvimento e propor } \\
& \text { programas e projetos cuja efetivação possa contribuir para alcançar os } \\
& \text { objetivos e as metas traçadas (BRUM et al., 2008, p. 142). }
\end{aligned}
$$

Esse tipo de regionalização passou a ser o mais utilizado no planejamento do RS, uma vez que passou por um período "probatório" desde 1994 até se institucionalizar e ser aceito como uma região de estudo e de referência para políticas públicas. Hoje é a única aceita por órgãos governamentais do Estado.

Esta regionalização não é um ponto pacífico e/ou aceito sem críticas, porém, busca na medida do possível agrupar regiões com características e/ou vocações semelhantes. Ademais, os Coredes são 
regiões administrativas reconhecidas e adotadas por órgãos oficiais, o que colabora para justificar a utilização desta regionalização (LISBOA; BAGOLIN, 2008, p. 152).

Após vinte anos de existência, embora ainda enfrentem dificuldades, conforme avaliam os estudiosos da matéria, os Coredes ocupam uma posição relevante no quadro institucional do Estado, devendo ser considerados uma das mais bem sucedidas experiências desse gênero no Brasil.

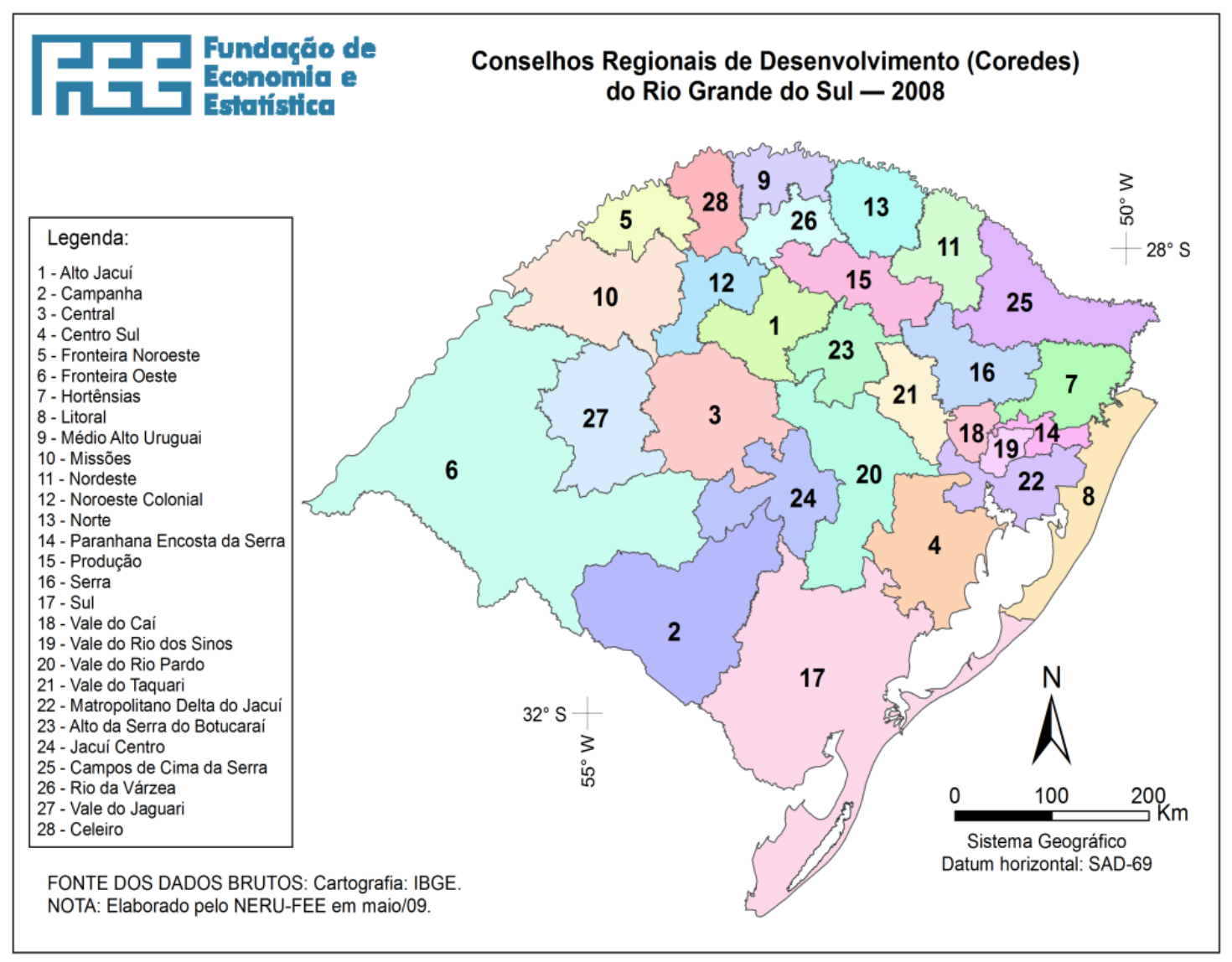

Figura 3.3.1.1. Os 28 Conselhos Regionais de Desenvolvimento.

Fonte: FEE, 2013. 


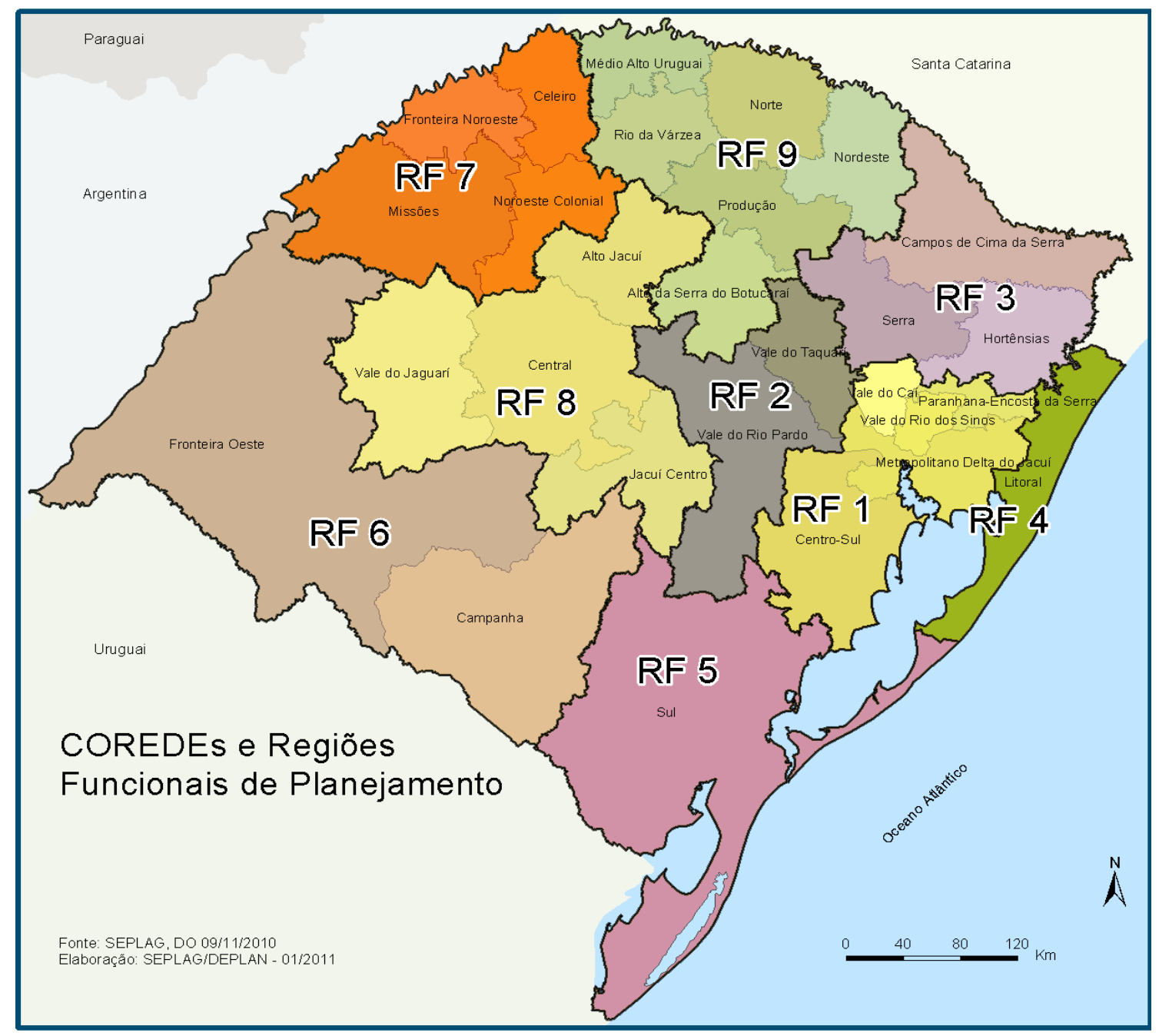

Figura 3.3.1.2. As Regiões Funcionais de Planejamento com seus respectivos Coredes. Fonte: FEE, 2013. 


\section{INDÚSTRIA NA FRONTEIRA NOROESTE DO RIO GRANDE DO SUL}

\subsection{SANTA ROSA}

A Região Fronteira Noroeste do Rio Grande do Sul tem como centro o município de Santa Rosa, que ao longo de seus mais de 80 anos de história assentou sua economia nas atividades agrícola, industrial e de serviços, atraindo para si, precisamente nas últimas décadas, a condição de município polo dessa Região.

A experiência recente da "Grande Santa Rosa", como foi tradicionalmente conhecida a microrregião gaúcha com 20 municípios, deu origem ao Corede Fronteira Noroeste, composto dos seguintes municípios (Figura 4.1.1): Alecrim, Alegria, Boa Vista do Buricá, Campina das Missões, Cândido Godói, Doutor Maurício Cardoso, Horizontina, Independência, Nova Candelária, Novo Machado, Porto Lucena, Porto Mauá, Porto Vera Cruz, Santa Rosa, Santo Cristo, São José do Inhacorá, Senador Salgado Filho, Três de Maio, Tucunduva e Tuparendi. A região tem mais de 210.000 habitantes e uma área de 4.689,0 km² e PIB per capita $\mathrm{R} \$ 15.583,00$.

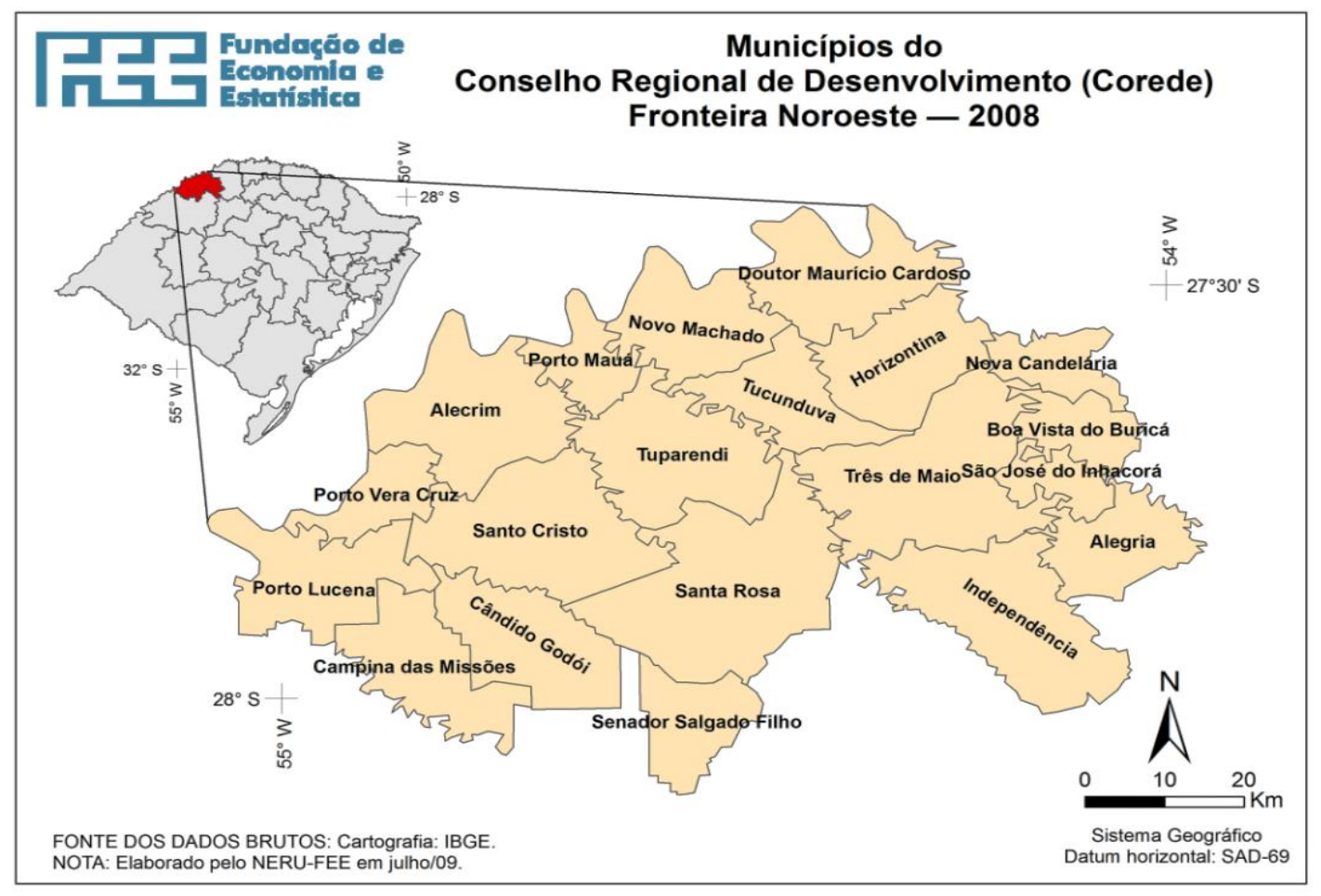

Figura 4.1.1. Os municípios do Corede Fronteira Noroeste

Fonte: FEE, 2012 
O desenvolvimento econômico desse município tem como marco inicial o período que compreende os últimos anos do século XIX até 1915, quando a região era habitada de forma esparsa por indígenas, posseiros e donos de glebas. A criação de colônias oficiais e particulares, como Santa Rosa em 1914, representou a consolidação do projeto de colonização regional, com a introdução de imigrantes europeus e seus descendentes provenientes das Colônias Velhas. Nesse primeiro momento, as atividades limitavam-se à instalação e sobrevivência, caracterizando, do ponto de vista econômico, a maior incipiência do processo de desenvolvimento regional (FIDENE, 1993).

Em 1918 dá-se a decisão governamental de levar a cabo um grande loteamento de terras rurais na região, até então desintegrada do contexto estadual. Esse projeto de colonização introduziu os primeiros agentes dinâmicos do processo de desenvolvimento na região: os promotores de serviços de loteamentos, os nacionais, os colonos de origem alemã e italiana e depois russa, polonesa e ucraniana são atraídos pela disponibilidade de terras agriculturáveis e com boas perspectivas de colheitas (SEGAT et al. 1982; FIDENE, 1993; CHRISTENSEN, 2004)

De modo geral, os colonos vinham de longe organizados em caravanas com recursos que lhes permitiam enfrentar as primeiras adversidades. Começavam a tomar conhecimento da terra para a qual estavam destinados. As terras fronteiriças que delineavam o Noroeste do Estado era o que lhes acenava para a realização dos seus sonhos e começo de vida. Aos poucos surgiam plantações de milho, feijão, batata-doce, trigo, hortaliças, os primeiros artesanatos rurais, como as olarias, as serrarias, os moinhos e as pequenas ervateiras (ZARTH, 1997).

Nesse momento a economia se caracteriza por dificuldades ligadas ao transporte e à comunicação, em vista da distância considerável entre o município e os principais centros do Estado. Mesmo sob condições adversas, a região alcançou um rápido crescimento a ponto de reivindicar sua emancipação político-administrativa de Santo Ângelo em 10 de agosto de 1931. O novo município foi instalado em um período em que o Brasil passava por transformações político-econômicas em decorrência de uma década anterior de questionamentos e crises que desembocaram na Revolução de 1930 (ZARTH, 1997; ROTTA, 1999).

A emancipação político-administrativa, combinada com a extensão da via férrea em 1928 até Passo das Pedras (atual município de Giruá), ampliada em 1937 até o povoado de Cruzeiro e, finalmente, em 1940, até a cidade de Santa Rosa, desencadeou um processo de transformação que atingiu todas as esferas da sociedade local. A via 
férrea permitiu a ligação da região com o restante do Estado e do País. Melhoraram as condições de transporte e diminuíram seus custos, as terras quadriplicaram o valor, e os agricultores intensificaram a produção de produtos exportáveis (ROTTA, 1999, p. 58). Com a possibilidade de maior escoamento da produção, surgiu a concorrência com produtos advindos de outras regiões. Esse último fator contribuiu para a inibição da atividade artesanal na região (FIDENE, 1993).

A indústria local foi a atividade econômica que sofreu maior impacto com a vinda da via férrea. Em todos os ramos havia cada vez menos empresas. Abandonam-se diversas produções, por exemplo, o azeite, o sabão, a cervejaria e a fundição foram pouco capazes de suportar a concorrência das máquinas. A vitória da estrada de ferro, que facilitou o escoamento da produção, também trouxe a regressão do artesanato que não pode competir com as fábricas da Depressão Central do RS (SEGAT et al., 1981, p. 130).

Em contraposição, entre as décadas de 1930 e 1950, a região experimentou um expressivo crescimento da produção agrícola e pecuária. Eram produzidas anualmente milho, feijão, linhaça, mandioca e fumo como produtos principais (CARDOSO, 1947, pp 51-54). A agricultura familiar deixava sua característica de subsistência, transformando-se, cada vez mais, numa atividade de mercado e adquire um novo perfil. As transformações que ocorriam fora da região também afetaram a economia de Santa Rosa. As estradas, os automóveis e os caminhões, alguma tecnologia, o incremento do comércio, a presença de meios de comunicação, a implantação de pequenas indústrias vinculadas à produção agropecuária e a chegada da estrada de ferro em 1940 são fatores que moldaram o perfil municipal e regional (FIDENE, 1993).

A produção agrícola que em 1939 era de 177.780 toneladas salta para as 332.080 toneladas em 1950 (ROCHE, 1969, pp. 283-285). Santa Rosa era, em 1950, a imagem da prosperidade, do dinamismo da população, levada em consideração as condições econômicas e físicas locais. Se a prioridade econômica anterior aos anos de 1950 se concentrava nas atividades produtivas de subsistência e o excedente para o mercado, o modelo de organização social construído a partir dos referenciais da imigração começa a se esgotar e abrir caminho para a crise da agricultura familiar e do próprio modelo. Com isso, um novo modelo agrícola incentiva a produção em maior escala da cultura baseada em trigo e soja. 
Concomitante à crise do antigo modelo agrícola, o chamado "ciclo do porco" se mostrou próspero, levando a produção excedente, tanto de animais vivos como da gordura animal (banha), para outras regiões do Estado até chegar a São Paulo, onde era comercializado nos diversos frigoríficos. A suinocultura transformou-se na principal fonte de renda para a agricultura familiar. Na tentativa de agregar mais valor à produção, um grupo composto por empresários e produtores locais avaliou a possibilidade de instalar um estabelecimento frigorífico com estruturas próprias para a industrialização de suínos no município. No ano de 1956, em assembleia geral da Associação Comercial, foi decidida a criação de um frigorífico com capital local. Em 12 de outubro de 1957 aconteceu o primeiro abate de suínos, que marca o início das atividades do Frigorífico Santa-rosense, constituído por vários associados, entre empresários, profissionais liberais e agricultores (ROTTA, 1999, p.59).

A rotatividade reduzida de culturas agrícola e a ausência de técnicas mais qualificadas de preservação e correção do solo acabaram por ocasionar uma queda nos níveis de produtividade, levando ao aumento do custo de produção do gado suíno e à perda da competitividade com outras regiões do Estado. A solução proposta pelo empresariado urbano tinha de passar pela modernização da agricultura e da agroindustrialização, bem como pela conquista de novos mercados consumidores.

Paralelamente às soluções apontadas, desencadeou-se na região a chamada "Operação Tatu" ${ }^{21}$, que consistiu em um programa de recuperação da fertilidade do solo (aplicação de calcário), facilitado pelo programa de modernização da agricultura e da implantação da chamada "revolução verde" (ROHLEDER, 2003 e CHRISTENSEN, 2004). Com os resultados do advento da "Operação Tatu”, a região estruturou as unidades fabris passando a produzir máquinas e equipamentos agrícolas, desde trilhadeiras até colheitadeiras automotrizes. Em 1947, a empresa Schneider e Logemann, de Horizontina, produzia a primeira trilhadeira da região e, em 1965, pioneiramente, a primeira colheitadeira automotriz no Brasil. (BUTTENBENDER, 2001).

Em um estudo comparativo dos três setores da economia de Santa Rosa, verifica-se na tabela 4.1.1 a participação dos setores primário, secundário e terciário na formação da sua renda interna. Em 1959, o percentual do setor primário municipal

\footnotetext{
${ }^{21}$ http://www.cienciadosolo.com.br/assistir/31/historia-da-operacao-tatu.
} 
$(48,3 \%)$ é superior à média estadual $(27,8 \%)$, tendo uma participação de $1,57 \%$ no Estado. Entretanto, o percentual de participação no Estado decai para 0,41\% em 1980.

Em 1959, a renda gerada no meio rural representava quase a metade da renda municipal; passados 20 anos, sua participação no contexto econômico municipal se reduz a 10\%. As emancipações ocorridas até os anos de 1970 refletiram diretamente no desempenho do setor primário, uma vez que a produtividade agrícola e pecuária se dá em ambiente rural, influenciando no desempenho do setor.

Tabela 4.1.1. Percentual da renda interna de Santa Rosa e estadual entre 1959 e 1980.

\begin{tabular}{|c|rcc|rll|lll|}
\hline Setor & \multicolumn{3}{|c|}{ Primário } & \multicolumn{3}{c|}{ Secundário } & \multicolumn{3}{c|}{ Terciário } \\
Ano & SR & RS & PE & SR & RS & PE & SR & RS & PE \\
\hline 1959 & 48,3 & 27,8 & 1,57 & 12,2 & 19,5 & 0,56 & 39,4 & 52,4 & 0,68 \\
\hline 1970 & 13,9 & 20,9 & 0,52 & 31,6 & 20,9 & 1,19 & 54,4 & 58,7 & 0,74 \\
\hline 1975 & 9,1 & 18,5 & 0,38 & 35,2 & 25,5 & 1,08 & 55,6 & 55,9 & 0,78 \\
\hline 1980 & 10,0 & 16,3 & 0,41 & 29,2 & 26,6 & 0,73 & 60,7 & 57,0 & 0,71 \\
\hline
\end{tabular}

Legenda: SR: Santa Rosa.

RS: Rio Grande do Sul.

PE: Participação do município no Estado do RS.

Fonte: Fundação Economia e Estatística (FEE), 1993.

A renda gerada pelo setor primário no intervalo de 20 anos é considerada muito inferior no âmbito estadual, uma vez que o município está inserido em ambiente de preponderância agrícola. Tal fato se deve no mínimo a dois fatores: o crescimento da produção do leite, do frango e das frutas obtidas em outras regiões do RS, que elevam a renda no setor primário no Estado e o nível de esgotamento do solo a que se chegou nas pequenas propriedades rurais da Grande Santa Rosa (FIDENE, 1993). À medida que avançam os anos, a renda produzida pela atividade atrelada ao setor secundário da economia, a indústria, encontra propensão de crescimento em detrimento do setor primário.

O setor secundário, conforme mostra a Tabela 4.1.1, teve um comportamento diferenciado, haja vista que, no primeiro ano da série, representava somente $12,2 \%$ da renda do município, ao passo que, nos anos subsequentes, cresceu significativamente 
$(29,2 \%)$ em virtude da existência de grandes indústrias vinculadas particularmente às demandas e aos excedentes da agropecuária regional.

Quando as atividades do setor primário perdem em dinamicidade, o setor secundário vem a reboque (puxado pelo setor primário). Porém, as emancipações ocorridas até os anos de 1970 não influenciaram o desempenho deste setor, demonstrando claramente que as principais indústrias localizavam-se na sede municipal (Santa Rosa).

O setor terciário confirma sua grande importância para a formação da renda municipal em 1980, quando 60,7\% eram gerados por atividades comerciais e de prestação de serviços (FIDENE, 1993).

Ao final da década de 1970, as dificuldades do cenário mundial repercutiam também localmente. Em Santa Rosa, a década de 1980 pode ser colocada como um momento em que os impactos da globalização começam a ser sentidos de forma mais efetiva, consolidando-se na década seguinte. Após duas décadas de relativo desenvolvimento econômico, impulsionado pelo processo de modernização da agropecuária e da agroindústria, a região defronta-se com sinais evidentes de esgotamento desse modelo. O fim de uma política agrícola mais "protecionista" evidencia as deficiências de capital próprio para fazer qualquer investimento em melhorias no processo de produção; o nível de endividamento de muitos agricultores, comerciantes e industriais torna-se insustentável (BECKER, BANDEIRA, 2000; BRUM， 2007; BUTTEMBENDER， 1995， 2007; DALLABRIDA， 2000; DALLABRIDA et al., 2007).

O elevado custo dos insumos agropecuários levou à descapitalização constante dos produtores, vindo também a repercutir no espaço urbano regional, muitas vezes dependente da geração de renda produzida no meio rural. Normalmente, em eventos dessa extensão e mesmo em condições adversas da natureza como as estiagens prolongadas, outros setores sentem diretamente os efeitos, causando o "efeito cascata" com perdas econômicas a toda sociedade. De forma individual ou através do modelo associativo-cooperativo $^{22}$, retomam-se algumas experiências de diversificação de culturas, produção de leite, suínos, hortifrutigranjeiros e outros, bem como experiências de agroindustrialização, visando à maior estabilidade nas fontes de renda e na agregação de valor (BUTTEMBENDER, 1995).

\footnotetext{
${ }^{22}$ Ver mais adiante, item 4.4, a questão do cooperativismo-associativismo agrícola e a produção de grãos.
} 
A participação da administração pública de Santa Rosa em buscar alternativas para promover o crescimento econômico do município desencadeou as primeiras preocupações pela definição de uma área industrial, ainda nos anos de 1970. Com o passar dos tempos projetaram-se outras áreas destinadas às instalações fabris, tais como fábricas de cimento, de móveis, panificadoras e metalúrgicas. No mapa do zoneamento urbano do município de Santa Rosa, visto pela Figura 4.1.2, verificam-se as instalações das áreas e dos distritos industriais pela entonação lilás.

Conforme dados fornecidos pala Prefeitura Municipal de Santa Rosa, a cidade possui vários tipos de indústrias agrupadas em categorias e localizadas em sua grande maioria no perímetro urbano. Independente de seu porte, majoritariamente do tipo microempresas, elas trabalham com matéria-prima atóxica, mas algumas liberam efluentes gasosos, líquidos e sólidos.

Os segmentos industriais do município santa-rosense são diversificados, conforme dados da Prefeitura Municipal: implementos agrícolas, funilarias e serralherias, olarias, artefatos de cimentos, óleos, café e carnes, couro e calçados, móveis, erva mate, carrocerias, sabão, embalagens e artigos plásticos, cosméticos, fibras e gráficas e panificadoras. Ver Tabela 4.1.2 sobre os principais gêneros industriais existentes entre 1970 e 1989.

Conforme a tabela 4.1.2, entre 1970 e 1989, o número geral de estabelecimentos industriais cresceu de 122 para 150; as indústrias de produtos alimentares diminuíram de 36 para 29; o segmento metalmecânico cresceu de 20 para 35 (Tabela 4.1.2, Figura 4.1.3). Chama atenção também que as indústrias de vestuário, de calçados e tecidos crescem em números consideráveis, isto é, corresponde ao quarto maior gênero municipal, passando de apenas uma para 19 indústrias de um universo de 150, correspondendo a um segmento que apresentou crescimento gradativo após os anos de 1970, o que justifica a atenção especial por parte dos agentes econômicos e políticos no sentido de fomentar ações que de fato auxiliaram no seu desenvolvimento, tais como o Serviço Nacional da Indústria (SENAI) e a Associação Comercial, Industrial, Serviços e Agropecuária de Santa Rosa (ACISAP) (FIDENE, 1993). 
Área URBANA DA SEDE MUNICIPAL ZINEAMENTI URBAND E SISTEMA VIÁRIQ

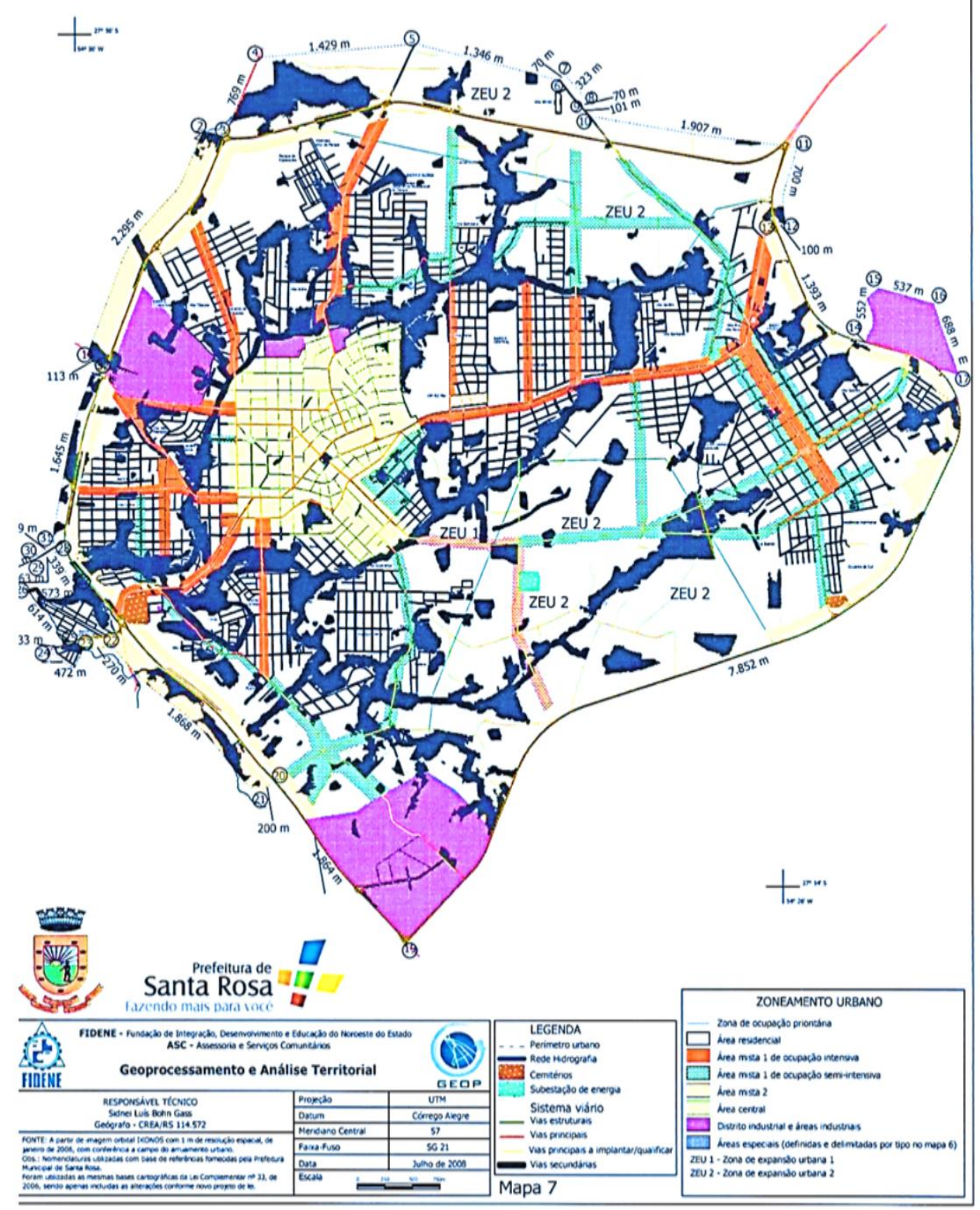

Figura 4.1.2. Zoneamento urbano e sistema viário do município de Santa Rosa. A coloração lilás indica os distritos e as áreas industriais.

Fonte: Prefeitura Municipal de Santa Rosa - Secretaria de Planejamento, 2013. 
Tabela 4.1.2. Evolução do número de empresas no setor secundário em Santa Rosa entre 1970 e 1989.

\begin{tabular}{|c|c|c|c|c|c|c|c|c|c|}
\hline Empresas & 1970 & 1975 & 1980 & 1981 & 1984 & 1986 & 1987 & 1988 & 1989 \\
\hline Minerais n/ Metálicos & 23 & 24 & 22 & 25 & 26 & 23 & 24 & 24 & 20 \\
\hline Metalúrgica & 8 & 14 & 13 & 16 & 16 & 15 & 16 & 17 & 22 \\
\hline Mecânica & 12 & 8 & 7 & 10 & 13 & 13 & 18 & 16 & 13 \\
\hline $\begin{array}{c}\text { Materiais } \\
\text { Elétr./Comun./Transp. }\end{array}$ & 5 & 4 & - & 3 & 2 & 6 & 5 & 5 & 6 \\
\hline Madeira & 19 & 19 & 17 & 32 & 16 & 15 & 13 & 10 & 11 \\
\hline Mobiliário & 5 & 3 & 4 & 7 & 5 & 9 & 8 & 9 & 11 \\
\hline Couro/Pele & 2 & 2 & - & 1 & 1 & 1 & 4 & 3 & 3 \\
\hline Têxtil & 1 & 2 & - & 2 & 2 & 4 & 5 & 6 & - \\
\hline Vest./Calç./Tecidos & 1 & 1 & - & 2 & 2 & 7 & 12 & 14 & 19 \\
\hline Produtos Alimentares & 36 & 26 & 25 & 28 & 18 & 24 & 29 & 31 & 29 \\
\hline Editorial/Gráfico & 2 & 3 & 3 & - & 4 & 4 & 4 & 2 & 2 \\
\hline Diversos & 10 & 8 & 10 & 5 & 16 & 8 & 0 & 8 & 14 \\
\hline Total & 122 & 115 & 101 & 131 & 118 & 129 & 148 & 145 & 150 \\
\hline
\end{tabular}

Fonte: IBGE e FEE - 1993, apud FIDENE, 1993.

\section{Número de indústrias alimentares e metalmecânicas em Santa Rosa-} RS entre 1970-1980-1989

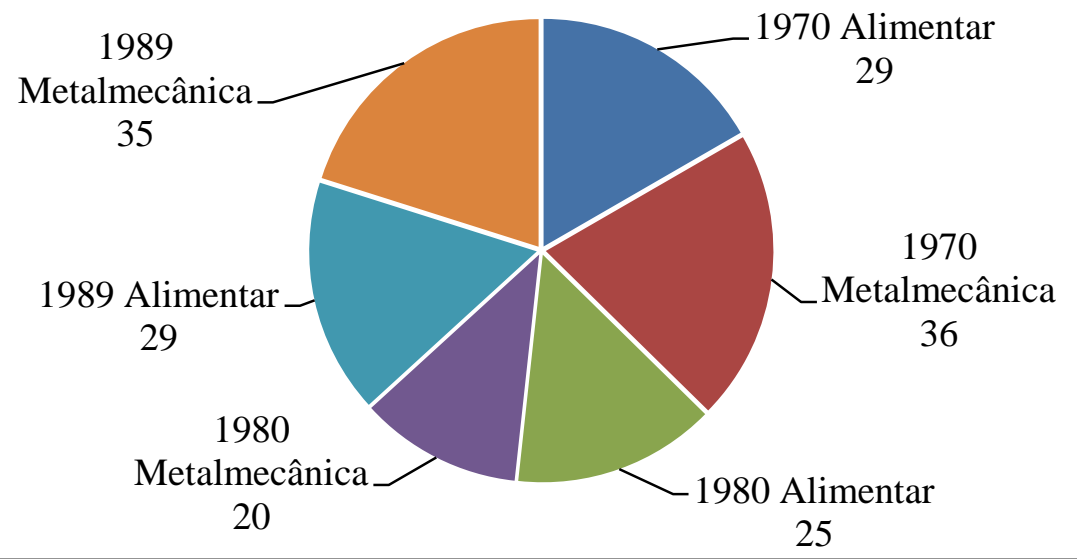

Figura 4.1.3. Número de indústrias dos segmentos alimentar e metalmecânico entre 1970/1980/1989.

Fonte: IBGE e FEE, apud FIDENE, 1993. 
No Distrito Industrial de Santa Rosa (4.1.4), que se inaugurou em 1991 à margem da RS 344, a maioria das empresas é do ramo metalúrgico (Figuras 4.1.5 e 4.1.6), distribuídas em poucas ruas. Dentre outras leis concernentes às áreas de ocupação industrial, a legislação prevê que:

a) as áreas industriais, o distrito e as indústrias já instaladas devem adequar-se à legislação ambiental federal e estadual que dispõe sobre o impacto e licenciamento ambiental (Art. $167 \S 6^{\circ}$ );

b) fica reservada para a expansão do distrito industrial a área compreendida num raio de 500 metros no entorno do mesmo, inserido no perímetro urbano, proibindo-se o uso para loteamento sem fins industriais (Art.167 $\S 7^{\circ}$ ); e

c) o poder público municipal manterá controle, diretamente ou mediante convênio com entidade que o faça, sobre emissão de ruídos ou quaisquer resíduos, sejam sólidos, líquidos ou gasosos, em condições que possam agredir o meio físico, a saúde ou a segurança da coletividade (Art. 169).

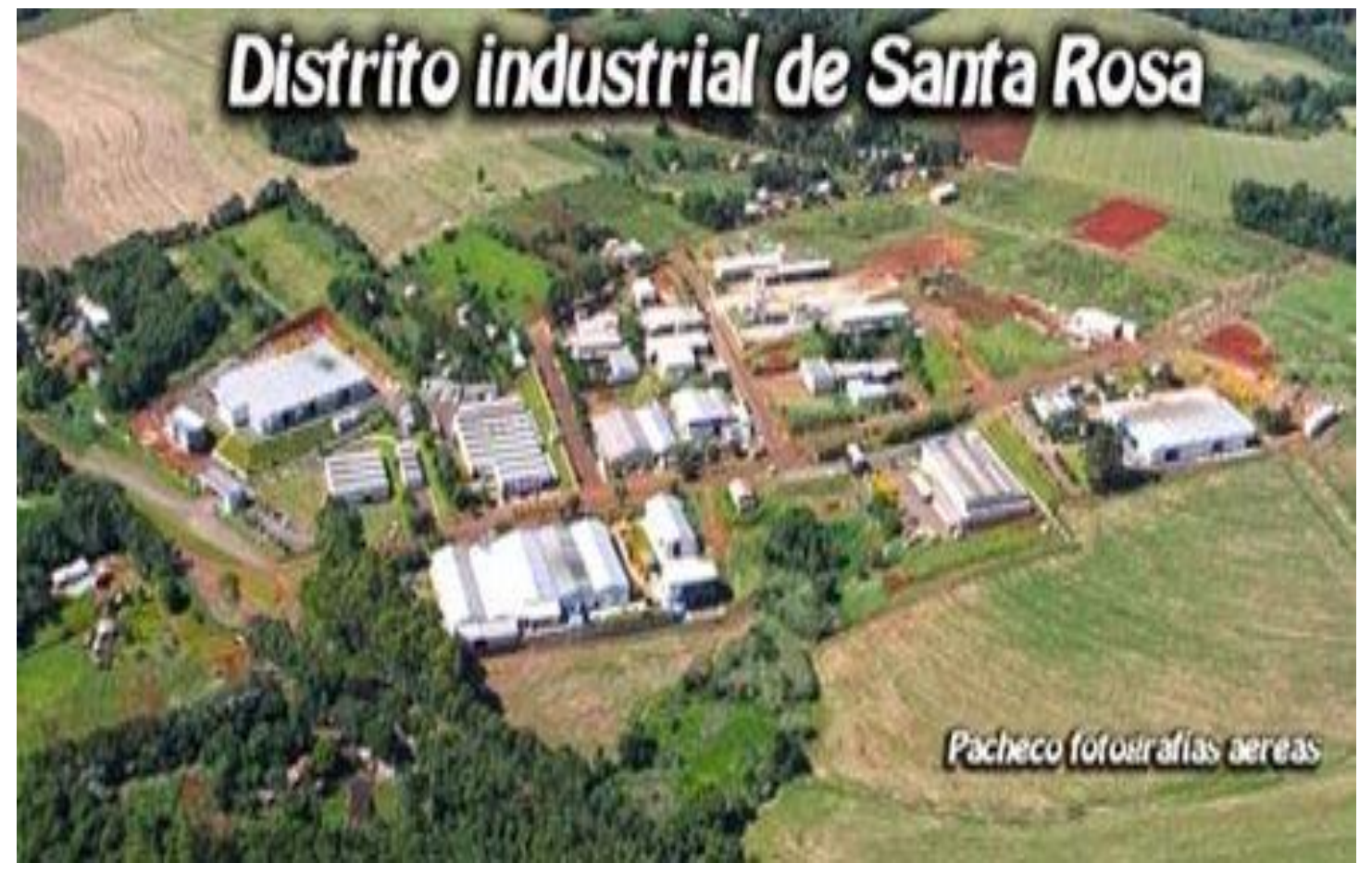

Figura 4.1.4. Distrito industrial (metalmecânico) de Santa Rosa.

Fonte: http://www.pachecofotografias.com.br/, 2014 


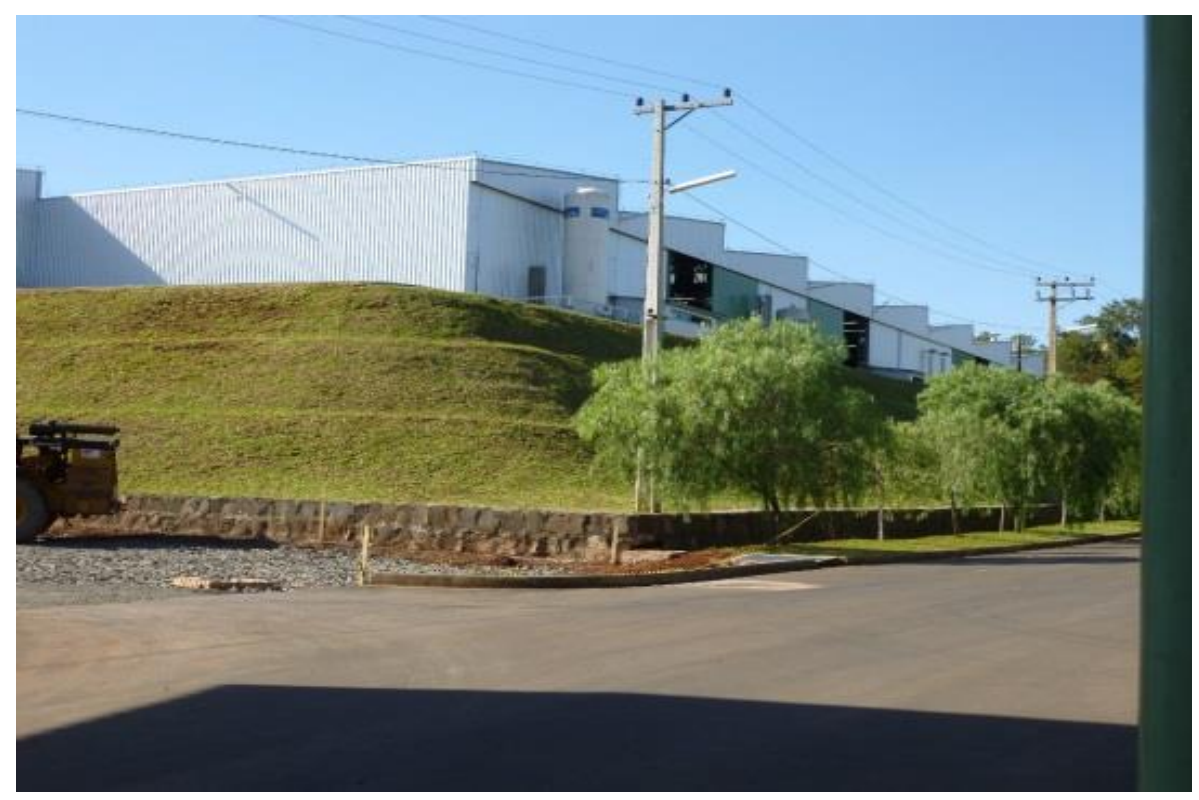

Figura 4.1.5. Fachada de metalúrgica, tipologia que mais caracteriza o

Distrito Industrial de Santa Rosa, à margem da rodovia RS 344.

Fonte: o autor

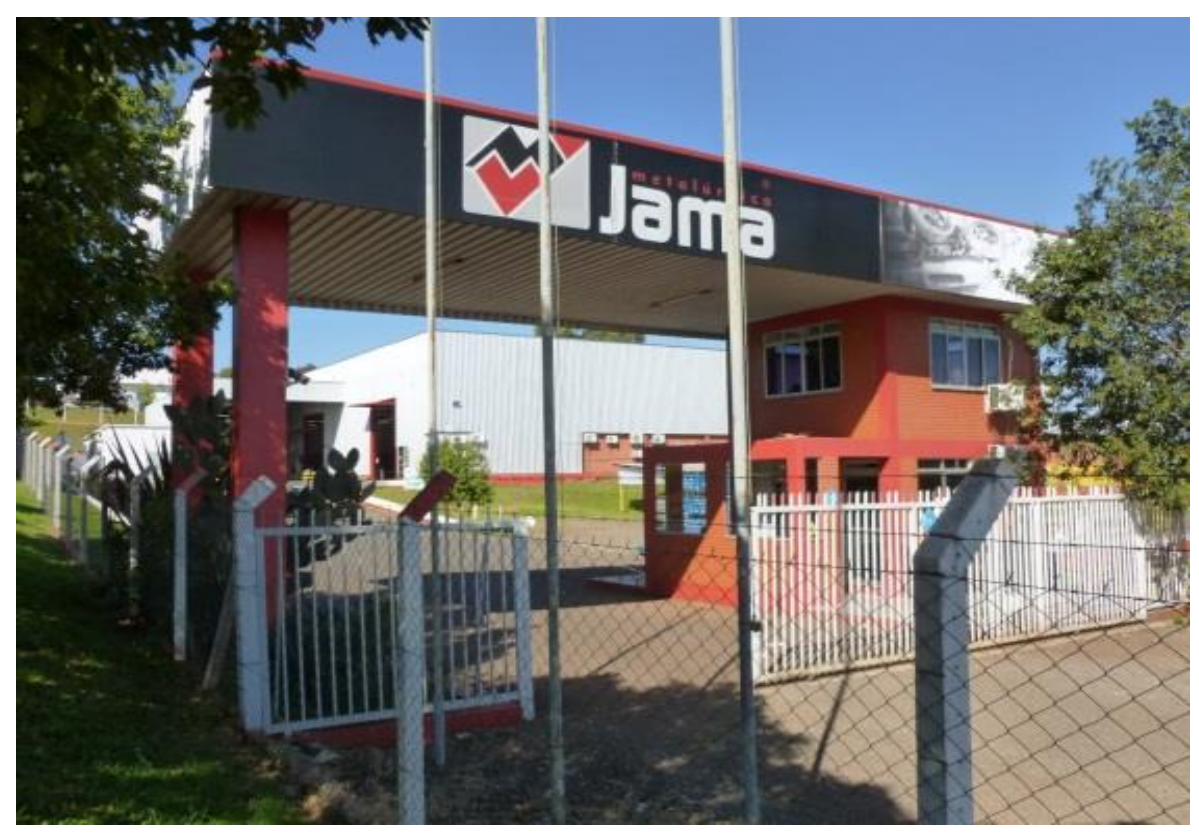

Figura 4.1.6. Fachada de metalúrgica, tipologia que mais caracteriza o

Distrito Industrial de Santa Rosa, à margem da rodovia RS 344.

Fonte: $\mathrm{O}$ autor

Um segmento que cresce na região de Santa Rosa e se projeta nacionalmente é o moveleiro, que inspirou iniciativas de representantes do segmento e da administração pública até ser criado em 2012 o Distrito Industrial Moveleiro, que compreende a 
extensão de cerca de 10 ha à margem da BR-472, distribuídos em 33 lotes entre $1.593 \mathrm{~m}^{2}$ e $2.947 \mathrm{~m}^{2}$ onde se vê na Figura 4.1.7. Não obstante, nos últimos meses, a administração pública municipal estuda incrementar o leque de empreendimentos naquele distrito, deixando de restringir a oferta ao ramo moveleiro.

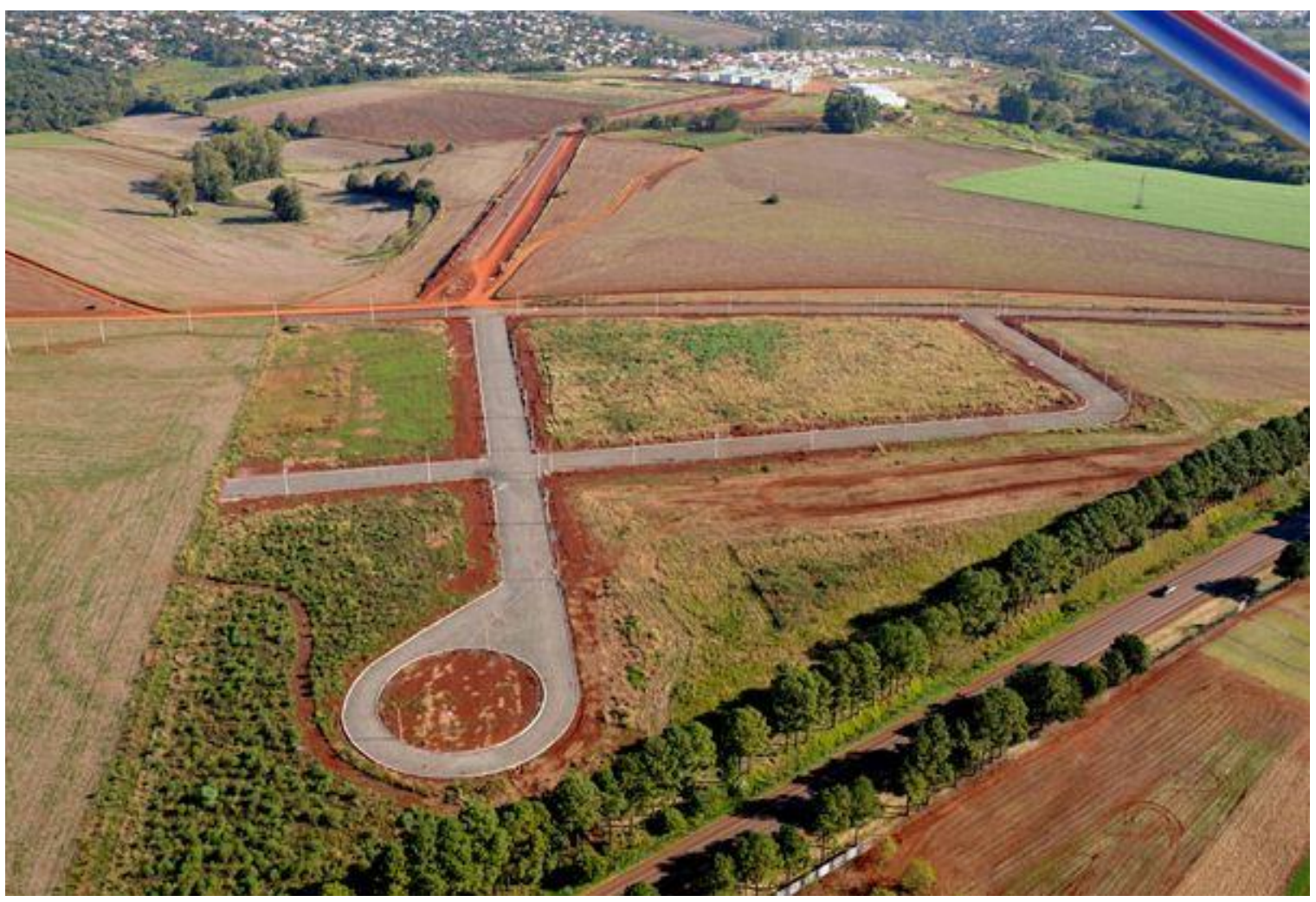

Figura 4.1.7. Distrito industrial moveleiro Ulrich Maske.

Fonte: http//www.zulupa.com.br, 2014.

O mapa abaixo traz o número de indústrias, em 2007, nos diversos municípios do Estado do RS e dá uma dimensão das concentrações industriais das quais geram maior valor agregado, dentre elas, as áreas imediatamente adjacentes à metrópole portoalegrense, incluindo a Serra (Caxias do Sul e Bento Gonçalves), Norte (Passo Fundo e Erechim) e Noroeste (Santa Rosa, Panambi e Ijuí), algumas áreas pontuais do Sul (Pelotas e Rio Grande) e o Centro (Santa Maria) gaúcho. As maiores concentrações de indústrias se verificam na porção sudeste e norte-noroeste do RS. A metade Sul, no entanto, é menos industrializada, podendo ser visualizado pela Figura 4.1.8.

Desde os anos de 1980, passou a ser adotado outro indicador econômico para a análise da composição da renda no município santa-rosense, uma vez que não mais existem dados sobre a renda interna para os anos posteriores àquela década. Qualquer 
município tem já consolidadas três fontes de recursos: as receitas próprias ${ }^{23}$, o índice de retorno do ICMS e o Fundo de Participação dos Municípios - FPM ${ }^{24}$, de cunho

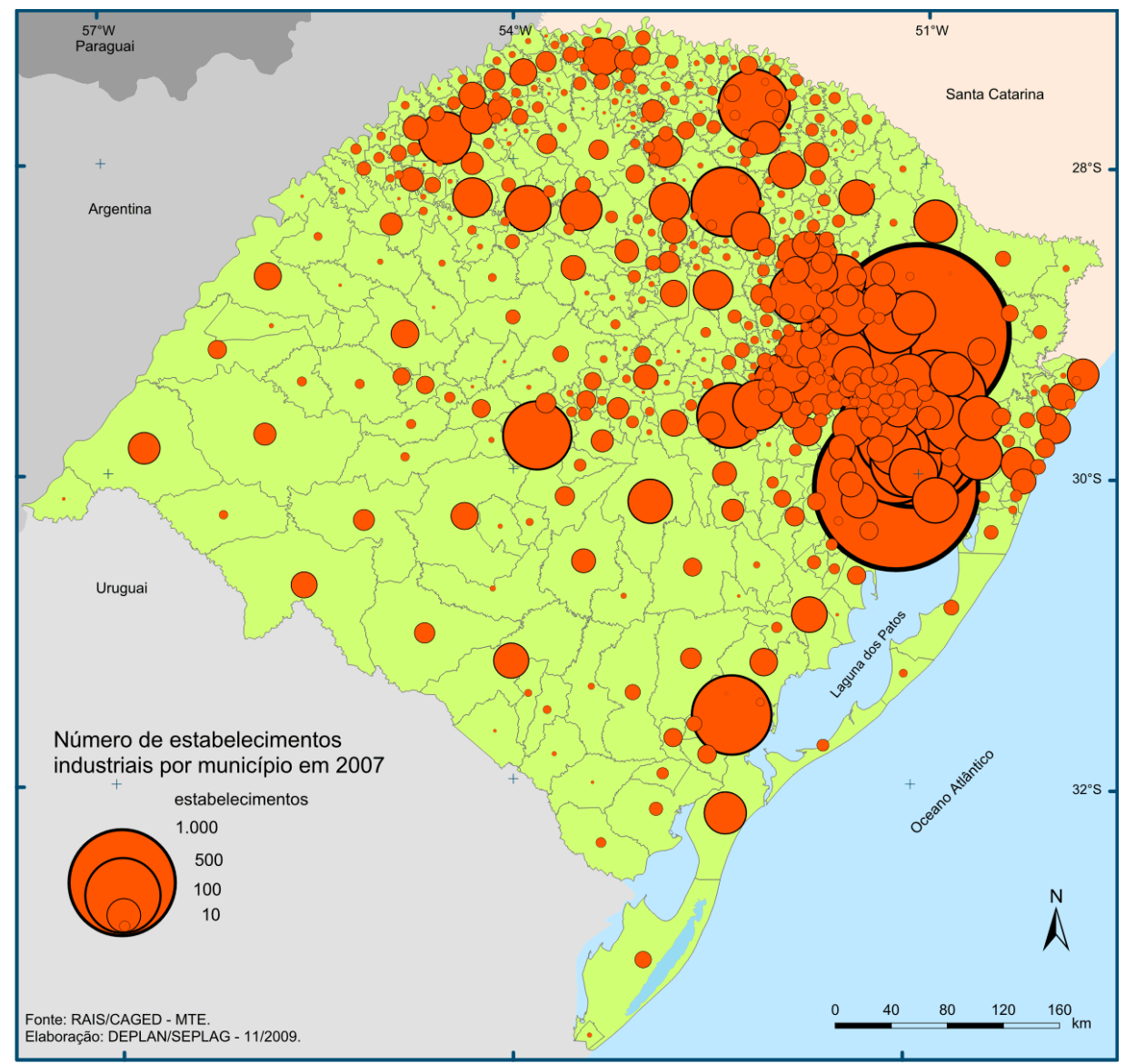

Figura 4.1.8 Número de estabelecimentos industriais por município, em 2007.

Fonte: DEPLAN/SEPLAG, 2014

${ }^{23}$ Segundo a Constituição de 1988, incluem-se na receita própria municipal: a receita tributária oriunda da cobrança do Imposto Predial e Territorial Urbano - IPTU; do Imposto sobre Serviços de Qualquer Natureza - ISS; do Imposto sobre Vendas a Varejo de Combustíveis Líquidos e Gasosos, exceto óleo diesel - IVVC; do Imposto sobre Transmissão "Intervivos" - ITBI-"intervivos", a qualquer título, por ato oneroso, de bens imóveis, as taxas e a Contribuição de Melhoria. Na receita própria incluem-se, ainda, a receita proveniente da receita patrimonial, agropecuária, industrial, de serviços (Ministério da Fazenda) Link de acesso: www3.tesouro.gov.br/legislacao/download/contabilidade/Manual.

${ }^{24}$ O Fundo de Participação dos Municípios (FPM) é constituído com recursos do Imposto de Renda e do Imposto sobre Produtos Industrializados (22,5\% da arrecadação líquida desses tributos). Do valor total do fundo, $10 \%$ são destinados às capitais. Dos 90\% restantes, 3,6\% vão para os Municípios do interior com mais de 156.216 habitantes e $86,4 \%$ aos demais Municípios, a partir de um piso de 10 mil habitantes. A distribuição desses recursos ocorre de acordo com o número de habitantes, sendo atribuído um coeficiente para cada faixa populacional (Ruckert e Rabelo, 2002 e 2005). 
respectivamente municipal, estadual e federal.

Dentre as transferências, a que mais se destaca é aquela efetuada pelo Estado para os municípios. Como é vigente no País, esta ocorre através da cota-parte do Imposto sobre Circulação de Mercadorias e Serviços (ICMS), que é formada pelo repasse de $25 \%$ da arrecadação total desse tributo para os municípios, via retorno do ICMS. O retorno é medido por meio de um coeficiente que inclui o valor adicionado fiscal (VAF) do município, com peso de $75 \%$, e outros fatores que, somados, representam $25 \%{ }^{25}$. Como tal transferência tem como principal variável de cálculo o valor adicionado gerado em cada município, a mesma leva em consideração o dinamismo municipal (BOVO, 1995, apud RUCKERT et al., 2002).

Apesar da diferenciação conceitual de renda interna e de valor adicionado fiscal, é perfeitamente admissível utilizar esse último na análise de desempenho do município (FIDENE, 1993). O VAF de um município corresponde ao valor que se agregou nas operações relativas à circulação de mercadorias e prestações de serviços realizadas em seu território em determinado ano civil, em relação ao valor adicionado em todo o Estado (FIDENE, 1993), e é definido através da Lei Complementar nº 63, de 11.01.90, em seu artigo $3^{\circ}$, parágrafo $1^{\circ}$ : “O valor adicionado corresponderá, para cada município, ao valor das mercadorias saídas, acrescido do valor das prestações de serviços no seu território, deduzido o valor das mercadorias entradas em cada ano civil" (RUZZARIN et al., 2010, p. 111).

Quanto maior o movimento econômico maior será o seu índice de participação no repasse de receitas oriundas da arrecadação do ICMS e o Imposto sobre Produtos Industrializados (IPI Exportação).

Parte do ICMS que o Estado arrecada é entregue aos municípios proporcionalmente à participação de cada um no movimento geral de operações que constituem fatos geradores desse imposto durante determinado exercício. O governo do estado fica com $75 \%$ e distribui aos municípios $25 \%$ da receita do ICMS. Isso significa

\footnotetext{
${ }^{25}$ Outros fatores correspondem, em 1999: população (7\%), área (7\%), número de propriedades rurais (5\%), produtividade primária $(3,5 \%)$, o inverso da taxa de evasão escolar $(0,33 \%)$, o inverso do coeficiente de mortalidade infantil $(0,33 \%)$, pontuação no projeto parceria $(0,17 \%)$ e pontuação fixa $(1,67 \%)$.
} 
que para cada R \$ 1,00 recolhido pelos contribuintes do ICMS para os cofres do estado, $\mathrm{R} \$ 0,25$ será dividido entre os municípios localizados em seu território.

O movimento econômico do município é assim representado: saídas (-) entradas = VAF (SEFAZ-RS, 2012). O município encaminha a Declaração Anual do Movimento Econômico e Fiscal (DAMEF) de seus contribuintes ao Estado, que por sua vez apura o total do movimento econômico do município. Esse valor é dividido pelo VAF total dos municípios do Estado, estabelecendo-se um índice que será utilizado tanto para a distribuição do ICMS, quanto para o IPI/Exportação (RUZZARIN et al.; 2010, p. 111).

Os índices de retorno de ICMS para o município de Santa Rosa oscilam na série histórica de quase vinte anos consecutivos, desde um índice de 0,78\% em 1975, passando pelo melhor desempenho em 1978 com 1,03\%, até decair para 0,51\% em 1993 (Tabela 4.1.3).

Tabela 4.1.3. Índices percentuais de retorno de ICMS para Santa Rosa entre 1975 e 1993.

$\begin{array}{lccc}\text { Ano } & \text { Índice } & \text { Ano } & \text { Índice } \\ 1975 & 0,78 & 1985 & 0,72 \\ 1976 & 0,90 & 1986 & 0,74 \\ 1977 & 1,00 & 1987 & 0,74 \\ 1978 & 1,03 & 1988 & 0,69 \\ 1979 & 0,91 & 1989 & 0,60 \\ 1980 & 0,75 & 1990 & 0,55 \\ 1981 & 0,67 & 1991 & 0,52 \\ 1982 & 0,65 & 1992 & 0,49 \\ 1983 & 0,69 & 1993 & 0,51 \\ 1984 & 0,77 & & \end{array}$

Fonte: Secretaria da Fazenda (SEFAZ) do RS, 1993.

A tabela 4.1.4 expõe variação percentual do VAF de diversas atividades econômicas em Santa Rosa entre 1980 e 1990. A produção agropecuária apresenta um bom desempenho no período indicado. Inicialmente, correspondeu a 17,8\%, em 1980 e saltou para 18,5\%, em 1990. O VAF gerado pelas indústrias de transformação caiu consideravelmente em níveis percentuais - 36,8\% em 1980 para 26,4\% em 1990 - mas a participação das indústrias de beneficiamento, no período, aumentou de $1,9 \%$ para $8,7 \%$. O setor de serviços no período praticamente manteve o já significativo percentual acima de 40 pontos. Em suma, a evolução do VAF santa-rosense no período indica um 
desempenho constante no setor primário e terciário, mas uma oscilante e significativa variação no setor secundário.

Tabela 4.1.4 A evolução da variação percentual do VAF das diversas atividades econômicas em Santa Rosa, entre 1980 e 1990.

\begin{tabular}{|c|c|c|c|c|c|c|c|c|c|c|c|}
\hline Ano & 1980 & 1981 & 1982 & 1983 & 1984 & 1985 & 1986 & 1987 & 1988 & 1989 & 1990 \\
\hline Agropec. & 17,8 & 18,6 & 18,5 & 21,6 & 15,4 & 15,9 & 17,3 & 19,0 & 19,0 & 15,7 & 18,5 \\
\hline $\begin{array}{c}\text { Extrat. } \\
\text { mineral }\end{array}$ & 0 & 0 & 0 & 0 & 0 & 0 & 0 & 0 & 0 & 0,1 & 1,0 \\
\hline $\begin{array}{c}\text { Ind. de } \\
\text { transform. }\end{array}$ & 36,8 & 37,1 & 36,1 & 31,1 & 39,4 & 35,8 & 41,6 & 33,8 & 28,9 & 22,8 & 26,4 \\
\hline $\begin{array}{c}\text { Ind. de } \\
\text { benefic. }\end{array}$ & 1,9 & 1,8 & 2,1 & 2,9 & 2,9 & 1,9 & 1,2 & 3,1 & 3,6 & 1,9 & 8,7 \\
\hline $\begin{array}{c}\text { Comércio } \\
\text { atacad. }\end{array}$ & 11,5 & 16,6 & 18,1 & 18,7 & 17,9 & 21,4 & 11,2 & 13,3 & 12,3 & 15,7 & 11,0 \\
\hline $\begin{array}{c}\text { Comércio } \\
\text { varejista }\end{array}$ & 27,6 & 25,5 & 25,2 & 24,1 & 24,2 & 23,3 & 25,3 & 29,9 & 35,4 & 35,9 & 21,2 \\
\hline Serviços & 3,7 & 0,4 & 0,1 & 1,6 & 0,2 & 1,4 & 0,9 & 0,4 & 0,5 & 7,4 & 13,3 \\
\hline \begin{tabular}{c} 
Outros \\
\hline
\end{tabular} & 0,5 & 0,1 & 0,1 & 0,1 & 0 & 0,2 & 2,2 & 0,3 & 0,4 & 0,4 & 0 \\
\hline
\end{tabular}

Fonte: Secretaria da Fazenda - RS.

Em 2010, a arrecadação de ICMS é evidenciada no mapa exibido pela Figura 4.1.9, que traz o desempenho dessa modalidade de imposto em todas as regiões Coredes do Estado do RS. Conforme o mapa, as áreas com maiores arrecadações são verificadas na Região Metropolitana Delta do Jacuí, do Rio dos Sinos, Paranhana, também a Região da Serra e áreas do Sul do Estado. Na mesorregião Noroeste do Estado, o comportamento em relação a esse imposto é semelhante à grande maioria de suas microrregiões, incluindo o Corede Fronteira Noroeste. No Norte, o destaque maior é para os Coredes Norte e Produção. 


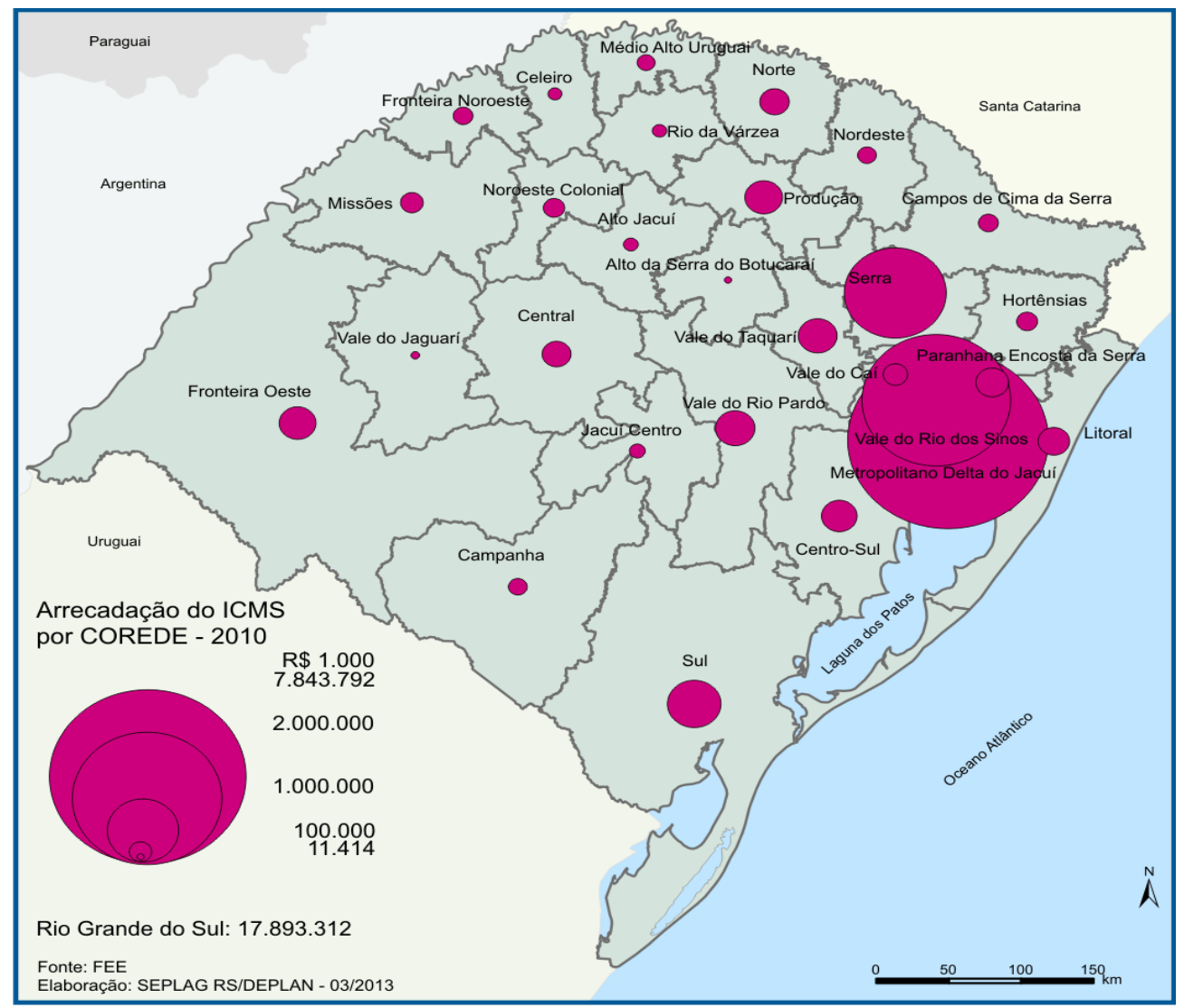

Figura 4.1.9. Arrecadação de ICMS por Corede no RS.

Fonte: FEE - SEPLAG RS/DEPLAN, 2014.

A Figura 4.1.10 traz informações referentes ao valor adicionado das principais atividades presentes no cenário econômico santa-rosense nos anos de 2010, 2011 e 2012 e a participação do município no montante estadual (SEFAZ-RS, 2014). As atividades econômicas que mais geram recursos para o município correspondem à agropecuária (produção e extração animal e vegetal) e as indústrias de transformação e de beneficiamento. Ao mesmo tempo, são muito significativos para o município o comércio atacadista, varejista e os serviços.

No período 2011-2012, a economia de Santa Rosa não passou por modificações muito profundas. Houve um aumento interessante $(3,12 \%)$ na produção agropecuária, de 9,15\% em 2011 para 12,27\% em 2012 (Figura 4.1.10); queda moderada em 3,2\% na indústria de beneficiamento e, leve, em $0,36 \%$ na indústria de transformação. Nota-se que a nomenclatura dos tipos de indústrias, no período, aumentou em comparação aos decênios de 1980 e 1990, com a entrada em cena da indústria de montagem e de acondicionamento e recondicionamento (Figura 4.1.10 e Tabela 4.1.4). 


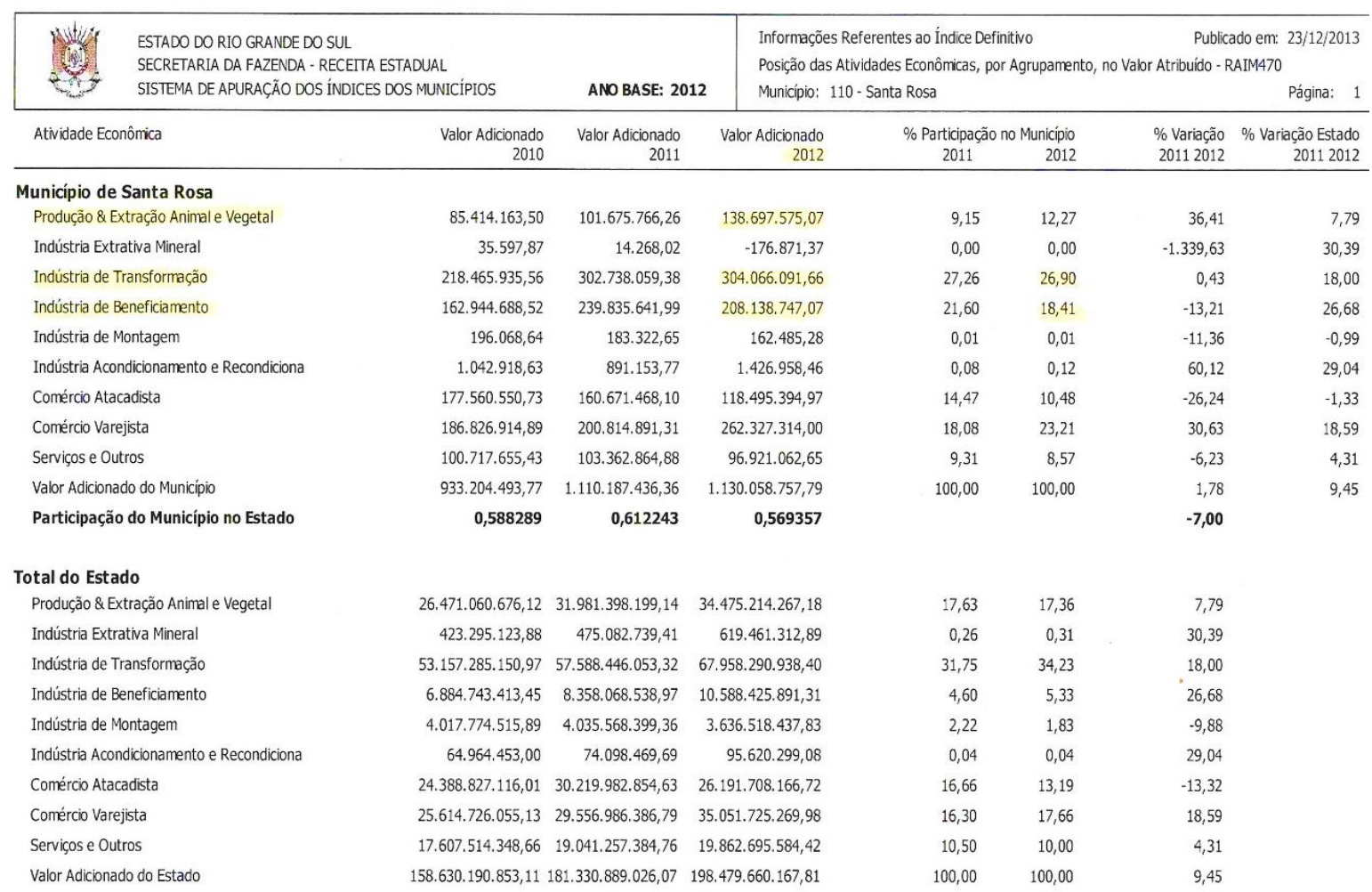

Figura 4.1.10. Posição das atividades econômicas, por agrupamento, no ano de 2012.

Fonte: SEFAZ-RS -2014.

Estrutura da renda interna conforme o valor adicionado de $2011 / 2012$

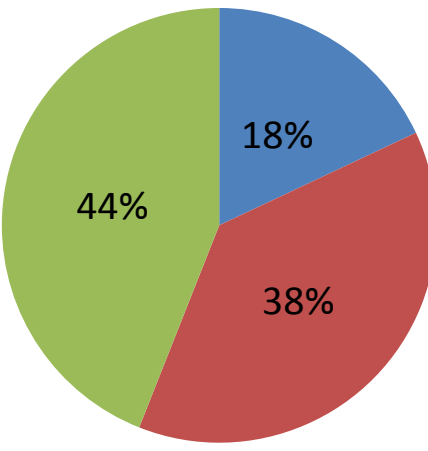

- Primário $\quad$ Secundário

- Terciário

Figura 4.1.11. Participação de Santa Rosa no Valor Adicionado Fiscal (VAF), em 2011-2012.

Fonte: SEFAZ-RS, 2014.

Pode-se inferir com base nos elementos das figuras 4.1.10 e 4.1.11, que a economia municipal no período 2011-2012 é representada em 44\% pelas atividades do setor terciário, em $38 \%$ pelas atividades fabris e em $18 \%$ pelas atividades do setor 
primário. O índice de retorno fiscal era 0,58\%, em 2010, 0,61\% em 2011 e 0,55\% em 2012, bastante semelhantes aos índices de 1970 a 1990 da Tabela 4.1.4 acima.

Conforme mostram os dados da tabela 4.1.5, atinentes ao ano de 2006, as empresas com maiores participações do valor adicionado fiscal representam o segmento alimentar e metalúrgico mecânico em $15,32 \%$ e 8,17\%, respectivamente. O terceiro, quinto, sexto e sétimo lugares também correspondem a empresas do segmento alimentar. Uma cooperativa agropecuária, tema que será abordado mais adiante, ocupa a oitava posição na participação do VAF.

Tabela 4.1.5. Relação das empresas de maior contribuição no VAF do município de Santa Rosa, com base em dados de 2006.

\begin{tabular}{|l|l|c|c|}
\hline & Empresa (Santa Rosa) 2006 & Valor em R\$ & $\%$ Participação \\
\hline 1 & $\begin{array}{l}\text { Alibem Comercial de Alimentos } \\
\text { (Frigorífico) }\end{array}$ & $84.724 .299,40$ & $15,32 \%$ \\
\hline 2 & $\begin{array}{l}\text { AGCO do Brasil Com. e Ind. } \\
\text { (Metalúrgica Mecânica) }\end{array}$ & $45.199 .868,21$ & $8,17 \%$ \\
\hline 3 & Pioneer Sementes & $18.073 .406,56$ & $3,27 \%$ \\
\hline 4 & Steffen Bebidas & $17.493 .248,14$ & $3,16 \%$ \\
\hline 5 & Camera Alimentos (Óleos vegetais) & $14.956 .392,64$ & $2,70 \%$ \\
\hline 6 & Eleva Alimentos (Atual BRF & $12.295 .871,57$ & $2,22 \%$ \\
& Alimentos) (Laticínios) & & $1,98 \%$ \\
\hline 7 & Du Pont Brasil & $10.993 .237,00$ & $1,54 \%$ \\
\hline 8 & Cooperativa Mista São Luiz & $8.536 .239,82$ & $1,23 \%$ \\
\hline 9 & Indústria Gráfica Sul & $6.821 .785,74$ & $0,86 \%$ \\
\hline 10 & RBS TV Santa Rosa & $553.155 .205,20$ & $100 \%$ \\
\hline & Demais Empresas & & $59,54 \%$ \\
\hline & Total & & \\
\hline
\end{tabular}

Fonte: Secretaria da Fazenda do Município de Santa Rosa, RS. 
Atualmente, conforme dados obtidos na Secretaria Municipal da Fazenda de Santa Rosa (JORNAL NOROESTE, 2014), os maiores retornos fiscais provêm do Frigorífico Alibem, seguido, nesta ordem, da Pioneer Sementes, da AGCO e da Camera Alimentos.

A Prefeitura de Santa Rosa fecha o ano de 2011 com arrecadação de R \$ 24 milhões de retorno de ICMS. Para 2012, a estimativa era de arrecadar R \$ 29,5 milhões. No ano de 2010, em relação ao de 2009, a economia de Santa Rosa cresceu 11,9\%. No mesmo período, a economia gaúcha cresceu 9,17\%. Conforme informações vindas da Secretaria Municipal da Fazenda de Santa Rosa, o crescimento real da receita é altamente significativo para o conjunto da arrecadação (...) e a indústria local puxou o crescimento, respondendo por aproximadamente 40\% (REVISTA AFINAL, 2011).

O valor adicionado nos municípios, apesar de não ser a única fonte para estudar impactos econômicos, gera elementos importantes e decisivos que indicam e relacionam as empresas mais relevantes em cada município. Outros indicadores econômicos podem ser analisados como meio de mensurar o desenvolvimento da região, tais como: renda per capita, geração de empregos, participação no PIB, entre outros. O PIB, por exemplo, corresponde ao total dos bens e serviços produzidos pelas unidades produtoras residentes destinados ao consumo final sendo, portanto, equivalente à soma dos valores adicionados pelas diversas atividades econômicas acrescida dos impostos, líquidos de subsídios, sobre produtos.

Uma vez visto o desempenho econômico temporal, que neste estudo remonta ao ano de 1959, estendendo-se até 2012, é possível admitir que para composição da renda interna o setor secundário em Santa Rosa sustenta a segunda posição a partir da década de 1970 e a mantém até 2012. O setor terciário, a partir da década de 1970, acelera sua renda e se mantém em primeira posição até 2012, exceto em 1959, quando é suplantada pela produção agropecuária e mineral. Sempre é bom frisar que embora Santa Rosa tenha construído seu alicerce na produção agropecuária, a produtividade do setor primário somente superou os outros dois no ano base de 1959, conforme já verificado na Tabela 4.1.1. Esse resultado admite afirmar que a renda obtida pelo setor primário é muito inferior ao da renda obtida pelos outros dois setores, uma vez que os últimos dois agregam maior valor em suas mercadorias e serviços.

Além do município de Santa Rosa da microrregião Fronteira Noroeste, outros como Horizontina, Três de Maio, Santo Cristo e Tuparendi apresentam participações diferenciadas na produtividade agrícola, na indústria e nos serviços para a composição 
do valor adicionado fiscal (VAF). Esses apresentam, em boa medida, uma diversidade de atividades econômicas, objeto deste estudo, como as indústrias alimentares (ervamate, panificação, leiteiro e frigorífico) e a metalmecânica. Ou seja, esses gêneros industriais não são exclusivos do município polo da microrregião. Outro estudo poderá estabelecer uma comparação intrarregional, interregional ou mesmo interestadual.

O Imposto sobre a Renda e Proventos de Qualquer Natureza - IR -, de competência da União, já constava no ordenamento jurídico brasileiro na Constituição de 1946, em seu artigo 15, inciso IV. Outro imposto federal - o Imposto sobre Produtos Industrializados, IPI - foi instituído pela Emenda Constitucional $n^{\circ} 18$, de $1^{\circ}$ de dezembro de 1965 (feita à Constituição de 1946), em seu artigo 11. Já o Fundo de Participação dos Municípios (FPM) teve origem nesta mesma Emenda Constitucional, em seu artigo 21, que também exigia a regulamentação do Fundo através de Lei Complementar. Inicialmente, o FPM era formado por $10 \%$ do produto da arrecadação dos impostos sobre renda (IR) e sobre produtos industrializados (IPI), descontados os incentivos fiscais vigentes na época, restituições e outras deduções legais referentes a esses impostos (Ministério da Fazenda (MF), 2012).

A regulamentação do FPM veio com o Código Tributário Nacional (CTN - Lei 5.172, de 25 de outubro de 1966), no seu artigo 91, e o início de sua distribuição deu-se em 1967. O critério de distribuição do FPM era então baseado unicamente na população dos Municípios. Posteriormente, o FPM foi ratificado pela Constituição Federal de 1967 (Art. 26), que recepcionou a regulamentação do CTN. Pouco depois de promulgada a Constituição de 1967, foi baixado o Ato Complementar da Presidência da República $\mathrm{n}^{\circ}$ 35, de 28 de fevereiro de 1967, que, dentre outras providências, categorizou os Municípios em Capitais e Interior, as Capitais recebendo $10 \%$ do montante total do FPM e o Interior o restante. Nova norma foi editada, o Decreto-Lei ${ }^{\circ} 1.881$, de 27 de agosto de 1981, criando mais uma categoria de Municípios denominada "Reserva", para aqueles Entes com população superior a 156.216 habitantes. A distribuição do FPM então ficou $10 \%$ para as Capitais, 3,6\% para a Reserva e 86,4\% para o Interior.

A Constituição de 1988 também ratificou o FPM (Art. 159, inciso I, alínea "b" e ADCT art. 34, $\S 2^{\circ}$, incisos I e III) e recepcionou a regulamentação do $\mathrm{CTN}$, tendo ainda aumentado gradativamente o percentual de participação do FPM no IR e IPI dos $17 \%$ na época até o valor de 22,5\%, a partir de 1993 e solicitado, em seu artigo 161, inciso II, que Lei Complementar regulamentasse a entrega dos recursos do Fundo. Isto foi realizado pela Lei Complementar $\mathrm{n}^{\circ}$ 62, de 28 de dezembro de 1989, que manteve o 
critério de repartição do CTN até 1991. Mais tarde, a Lei Complementar no 71, de 3 de setembro de 1992, prorrogou o critério do CTN "até que lei específica sobre eles disponha, com base no resultado do Censo de 1991, realizado pela Fundação IBGE" (Ministério da Fazenda, 2012).

Outras Leis Complementares foram sendo sucessivamente aprovadas, dilatando até hoje, com alguns ajustes, o critério de repartição do CTN, a saber: $n^{\circ} 72$, de 29 de janeiro de 1993; nº 74, de 30 de abril de 1993; nº 91, de 22 de dezembro de 1997; e $\mathrm{n}^{\mathbf{o}}$ 106, de 23 de março de 2001.

Adicionalmente, a Emenda Constitucional no 14, de 12 de setembro de 1996, por meio da alteração do Art. 60 do Ato das Disposições Constitucionais Transitórias ADCT - criou o Fundo de Manutenção e Desenvolvimento do Ensino Fundamental e de Valorização do Magistério - FUNDEF -, cuja fonte de recursos foi composta pela dedução de $15 \%$ nos repasses do Fundo de Participação dos Estados, do Fundo de Participação dos Municípios, da Lei Complementar 87/96, do ICMS estadual e do IPIExportação. Esta Emenda foi regulamentada pela Lei no 9.424, de 24 de dezembro de 1996, e os descontos do FUNDEF passaram a ser realizados a partir de janeiro de 1998.

Mais tarde, a Emenda Constitucional n ${ }^{\circ}$ 53, de 19 de dezembro de 2006, também por meio da alteração do Art. 60 do ADCT, substituiu o FUNDEF pelo Fundo de Manutenção e Desenvolvimento do Ensino Básico e de Valorização do Magistério FUNDEB -, cuja fonte de recursos incorporou novas transferências intergovernamentais obrigatórias, mantendo todas as anteriores, inclusive o FPM. Esta Emenda foi regulamentada pela Medida Provisória n 3 339, de 28 de dezembro de 2006, e os descontos correspondentes efetivados a partir de janeiro de 2007. A Medida Provisória foi transformada na Lei $\mathrm{n}^{\mathrm{o}} 11.494$, de 20 de junho de 2007. Atualmente, a dedução do FUNDEB é de $20 \%$ do valor do repasse (MF, 2012).

Uma alteração importante foi introduzida pela Emenda Constitucional $n^{\circ} 55$, de 20 de setembro de 2007, que acrescentou a alínea "d" ao art. 159, inciso I, adicionando $1 \%$ ao percentual do FPM (que assim passou a ter alíquota de $23,5 \%$ ); este percentual a mais, entretanto, seria acumulado na Conta Única do Tesouro Nacional ao longo de 12 meses, para ser entregue aos Municípios por seu valor integral no $1^{\circ}$ decêndio de dezembro de cada ano.

Os contribuintes do Imposto de Renda - IR e do Imposto sobre Produtos Industrializados - IPI recolhem esses impostos regularmente na rede bancária, de acordo com a legislação pertinente. O montante dessa arrecadação é transferido por 
cada instituição financeira, conforme previsão contratual entre o banco e a Receita Federal do Brasil - RFB para a Conta Única do Tesouro Nacional - CTU. Os bancos repassam as informações relativas ao recolhimento efetuado para a RFB.

Decendialmente (10 dias), por meio de processamento eletrônico, a RFB classifica o montante da arrecadação bruta de tributos relativo ao período e das deduções correspondentes (restituições, retificações e compensações), se houverem, e também dos incentivos fiscais - Fundo de Investimentos do Nordeste - Finor e os Fundos de Investimentos da Amazônia - Finam, apurando, desta forma, a arrecadação líquida do período. Tais informações são registradas no Sistema Integrado de Administração Financeira do Governo Federal - SIAFI (Ministério da Fazenda, 2012).

Decendialmente, a Secretaria do Tesouro Nacional - STN - consulta no SIAFI as informações do decêndio anterior e transfere ao Banco do Brasil o valor global a ser repassado naquele período, o que, no caso do FPM, corresponde a 22,5\% da arrecadação líquida do IR e do IPI. O Banco do Brasil, por sua vez, credita nas contas correntes dos Municípios os respectivos valores que lhes cabem, segundo percentuais calculados e informados anualmente pelo Tribunal de Contas da União - TCU -, até o último dia útil do ano anterior, com a dedução do valor correspondente ao Fundo de Manutenção e Desenvolvimento da Educação Básica e de Valorização dos Profissionais da Educação - FUNDEB.

De acordo com o art. $4^{\circ}$ da Lei Complementar 62/1989, os valores relativos ao FPM devem ser creditados decendialmente aos Municípios, até os dias 10, 20 e 30 de cada mês, mediante crédito em conta aberta com essa finalidade no Banco do Brasil. Caso a data caia em fim de semana ou feriado, o repasse é antecipado para o primeiro dia útil anterior. O valor transferido toma por base a arrecadação líquida do IR e do IPI do decêndio anterior.

O primeiro critério de repartição do FPM, constante da edição inicial do CTN, em 1966, era exclusivamente populacional, aumentando o valor da cota individual conforme aumentava a população do Município; ao longo dos anos, esse critério foi recebendo alterações. Hoje, o critério vigente se dá pelos percentuais individuais de participação dos Municípios que são calculados anualmente pelo TCU e por ele publicados em Decisão Normativa no Diário Oficial da União até o último dia útil de cada exercício (CTN, art. 92). O cálculo é feito com base em informações prestadas ao TCU até o dia 31 de outubro de cada ano pelo Instituto Brasileiro de Geografia e 
Estatística - IBGE, informações estas compostas da população de cada Município e da renda per capita de cada Estado (Ministério da Fazenda, 2012).

Os Municípios do Interior são aqueles que não são Capitais, sendo que os da Reserva também participam acumulativamente deste critério. A norma legal vigente neste caso é o Decreto Lei $\mathrm{n}^{\circ} 1.881$, de 27 de agosto de 1966, ratificado pela Lei Complementar $n^{\circ} 62$, de 28 de dezembro de 1989, documentos estes que levam a duas tabelas: uma, de percentuais de participação dos Estados no FPM (Tabela 4.1.6); outra, de coeficientes por faixa de habitantes municipais (Tabela 4.1.7). A Tabela 4.1.6 vem sendo reemitida anualmente pelas Decisões Normativas do TCU que tratam das repartições do FPE/FPM.

Tabela 4.1.6. FPM Interior - Participação dos Estados no total a distribuir

\begin{tabular}{|c|c|c|c|}
\hline Estado & Participação \% & Estado & Participação \% \\
\hline Acre & 0,2630 & Paraíba & 3,1942 \\
\hline Alagoas & 2,0883 & Paraná & 7,2857 \\
\hline Amapá & 0,1392 & Pernambuco & 4,7952 \\
\hline Amazonas & 1,2452 & Piauí & 2,4015 \\
\hline Bahia & 9,2695 & Rio de Janeiro & 2,7379 \\
\hline Distrito Federal & 0,0000 & Rio G do Norte & 2,4324 \\
\hline Ceará & 4,5864 & Rio G do Sul & 7,3011 \\
\hline Espírito Santo & 1,7595 & Rondônia & 0,7464 \\
\hline Goiás & 3,7318 & Roraima & 0,0851 \\
\hline Maranhão & 3,9715 & Santa Catarina & 4,1997 \\
\hline Mato Grosso & 1,8949 & São Paulo & 14,2620 \\
\hline Mato G. do Sul & 1,5004 & Sergipe & 1,3342 \\
\hline Minas Gerais & 14,1846 & Tocantins & 1,2955 \\
\hline Pará & 3,2948 & & 100,0000 \\
\hline
\end{tabular}

Fonte: (Resolução TCU no 242/90 de 02 de janeiro de 1990, apud Ministério da Fazenda, 2012).

Verifica-se que os Estados de São Paulo, Minas Gerais, Bahia, Rio Grande do Sul, Paraná, Pernambuco, Ceará e Santa Catarina são os que mais participam na geração 
de impostos que incidem no cálculo de repasses do FPM, por outro lado Acre, Amapá, Rondônia e Roraima são os que menos participam. Minas Gerais é o estado brasileiro que tem o maior número de municípios, com 853 (IBGE, 2014) variando, em termos populacionais no ano de 2013, entre 2. 479. 175 em Belo Horizonte e 825 habitantes em Serra da Saudade. Minas Gerais ainda busca criar mais outros 64 municípios, totalizando 915.

Tabela 4.1.7. FPM - Interior - coeficientes por faixa de habitantes

\begin{tabular}{|c|c|c|c|}
\hline Faixa de habitantes & Coeficiente & Faixa de habitantes & Coeficiente \\
\hline Até 10.188 & 0,6 & De 61.129 a 71.316 & 2,4 \\
\hline De 10.189 a 13.584 & 0,8 & De 71.317 a 81.504 & 2,6 \\
\hline De 13.585 a 16.980 & 1,0 & De 81.505 a 91.692 & 2,8 \\
\hline De 16.981 a 23.772 & 1,2 & De 91.69310 .1880 & 3,0 \\
\hline De 23.773 a 30.564 & 1,4 & De 10.1881 a 115.464 & 3,2 \\
\hline De 30.565 a 37.356 & 1,6 & De 115.465 a 129.048 & 3,4 \\
\hline De 37.357 a 44.148 & 1,8 & De 129.049 a 142.632 & 3,6 \\
\hline De 44.149 a 50.940 & 2,0 & De 142.633 a 156.216 & 3,8 \\
\hline De 50.941 a 61.128 & 2,2 & Acima de 156.216 & 4,0 \\
\hline
\end{tabular}

Fonte: Decreto Lei n ${ }^{\circ} 1.881 / 1981$ apud Ministério da Fazenda, 2012.

Além dos débitos com a União, Estados e Municípios têm que lidar com as flutuações na arrecadação de impostos provocadas por medidas de desonerações fiscais feitas pelo Governo Federal para enfrentar crises econômicas. São renúncias fiscais para incentivar setores específicos da economia mais atingidos pelas crises, ou os que têm maior potencial para aquecer a economia, como no caso da redução do Imposto sobre Produtos Industrializados (IPI) para automóveis e eletrodomésticos (REVISTA DO SENADO, 2013, p. 33).

O problema é que as desonerações de IPI e de Imposto de Renda têm impacto direto no Fundo de Participação dos Municípios (formado por 22,5\% da arrecadação desses impostos). As desonerações sobre o IPI e o IR (2013 e 2014) vão levar à redução de $23,5 \%$ sobre os valores a serem repassados aos municípios pelo FPM. Dessa forma, em 2013 o FPM repassará aos municípios R\$2,23 bilhões a menos (REVISTA DO SENADO, 2013, p. 33). 
A Confederação Nacional de Municípios (CNM) informa que, só com as desonerações do IPI para automóveis até 31 de dezembro de 2013, o FPM será reduzido em $\mathrm{R} \$ 1$ bilhão. Ao cálculo anterior da entidade - R 2 bilhões em desonerações de IPI com impacto de R $\$ 485$ milhões no FPM —, somam-se, com a prorrogação, outros $\mathrm{R}$ \$ 2,2 bilhões em renúncia de IPI: menos R 517 milhões para os municípios (REVISTA DO SENADO, 2013, p. 33).

Santa Rosa no censo demográfico de 2010 registrou uma população de 68.587 habitantes (IBGE, 2013) e a projeção populacional para 2014 foi estimada em torno de 72.000 habitantes. O Fundo de Participação dos Municípios (FPM) vem tendo um comportamento entre 1996 e 2013 descrito na Tabela 4.1.8. Entre os anos de 1996 a 2013, observa-se o crescimento constante dos valores de repasses do FPM para o município de Santa Rosa. Pode-se verificar que o desempenho municipal no período mencionado melhorou e o coeficiente estipulado pela faixa de habitantes conforme o Decreto Lei n ${ }^{\circ}$ 1.881/1981, provavelmente saltará de 2,4 para 2,6 nos próximos anos.

Tabela 4.1.8. Valores (R\$) transferidos para Santa Rosa pelo FPM entre 1996 e 2013.

$\begin{array}{cc}\text { ANO } & \text { FPM } \\ 1996 & 3.387 .814 \\ 1997 & 3.632 .349 \\ 1998 & 3.625 .917 \\ 1999 & 3.987 .845 \\ 2000 & 4.298 .940 \\ 2001 & 4.861 .850 \\ 2002 & 5.995 .905 \\ 2003 & 6.171 .749 \\ 2004 & 6.740 .072 \\ 2005 & 8.318 .324 \\ 2006 & 9.104 .942 \\ 2007 & 10.381 .605 \\ 2008 & 13.764 .521 \\ 2009 & 12.901 .534 \\ 2010 & 13.855 .605 \\ 2011 & 17.118 .201 \\ 2012 & 17.672 .563 \\ 2013 & 18.981 .848\end{array}$

Fonte: Transferências constitucionais - www.tesouro.gov.br, 2014. 


\subsection{PEQUENA PROPRIEDADE RURAL}

A divisão do Estado do Rio Grande do Sul em duas unidades fundiárias com características físicas, socioeconômicas e culturais distintas: a área de campo e a área de mata, ocupadas respectivamente pelos fazendeiros e os colonos, está intimamente vinculada com a história da ocupação de seu território (Figura 4.2.1). O embasamento da organização agrária da Região Noroeste do Rio Grande do $\operatorname{Sul}^{26}$ se deu somente no final do século XIX quando nas áreas florestais se instalaram as primeiras colônias, denotando um período de ocupação mais tardio em comparação às outras áreas do Estado devido ao processo migratório (Figura 4.2.2) (BANDEIRA, 2010; MANTELLI, sd; BOHN GASS, et. al., 2014).

Os tipos de vegetação original existentes na região condicionaram de forma significativa à ocupação do território e a sua própria formação social. Originalmente o território do Rio Grande do Sul era recoberto por três formações vegetais básicas, ou seja, as áreas de mata tropical e subtropical, as áreas de campo nativo e as áreas de vegetação litorânea, como podem ser observadas na Figura 4.2.1. Estas formações predominavam no território rio-grandense antes da vinda dos imigrantes europeus.

A borda da mata separa áreas distintas: os limites da zona de mata com o campo. A colonização oficial encontrou êxito em áreas onde a ausência da grande lavoura propiciava a formação da pequena propriedade. A região da antiga mata subtropical apresentava características inerentes às das zonas de colonização, com o predomínio da pequena propriedade rural, da policultura destinada à subsistência familiar e ao abastecimento do mercado interno. Além disso, essa região tem importância com o desenvolvimento de uma lavoura voltada ao comércio de itens como o trigo, o milho e a soja (MANTELLI, s/d).

O desmatamento e a consequente implantação agrícola no Rio Grande do Sul coincidem com o período de colonização. Desse modo, os colonos imigrantes, cujas principais correntes foram representadas pelos alemães em 1824, os italianos em 1875 e,

\footnotetext{
${ }^{26}$ A denominação Região Noroeste do Rio Grande do Sul a qual o item se refere é composta pelos Conselhos Regionais de Desenvolvimento - Coredes - Noroeste Colonial, Fronteira Noroeste e Celeiro, com um conjunto de 52 municípios, que abrange um total de $14.620 \mathrm{Km}^{2}$, com uma população total de mais de 500.000 habitantes, como pode ser observado no mapa. Esta denominação se tornou usual na região em virtude da inserção da Universidade Regional do Noroeste do Estado do Rio Grande do Sul - UNIJUÍ - e dos projetos desenvolvidos pelos pesquisadores desta instituição.
} 
posteriormente os poloneses e outras nacionalidades, estabeleceram-se em áreas onde se concentrava a quase totalidade de áreas arborizadas (Figuras 4.2.1 e 4.2.2).

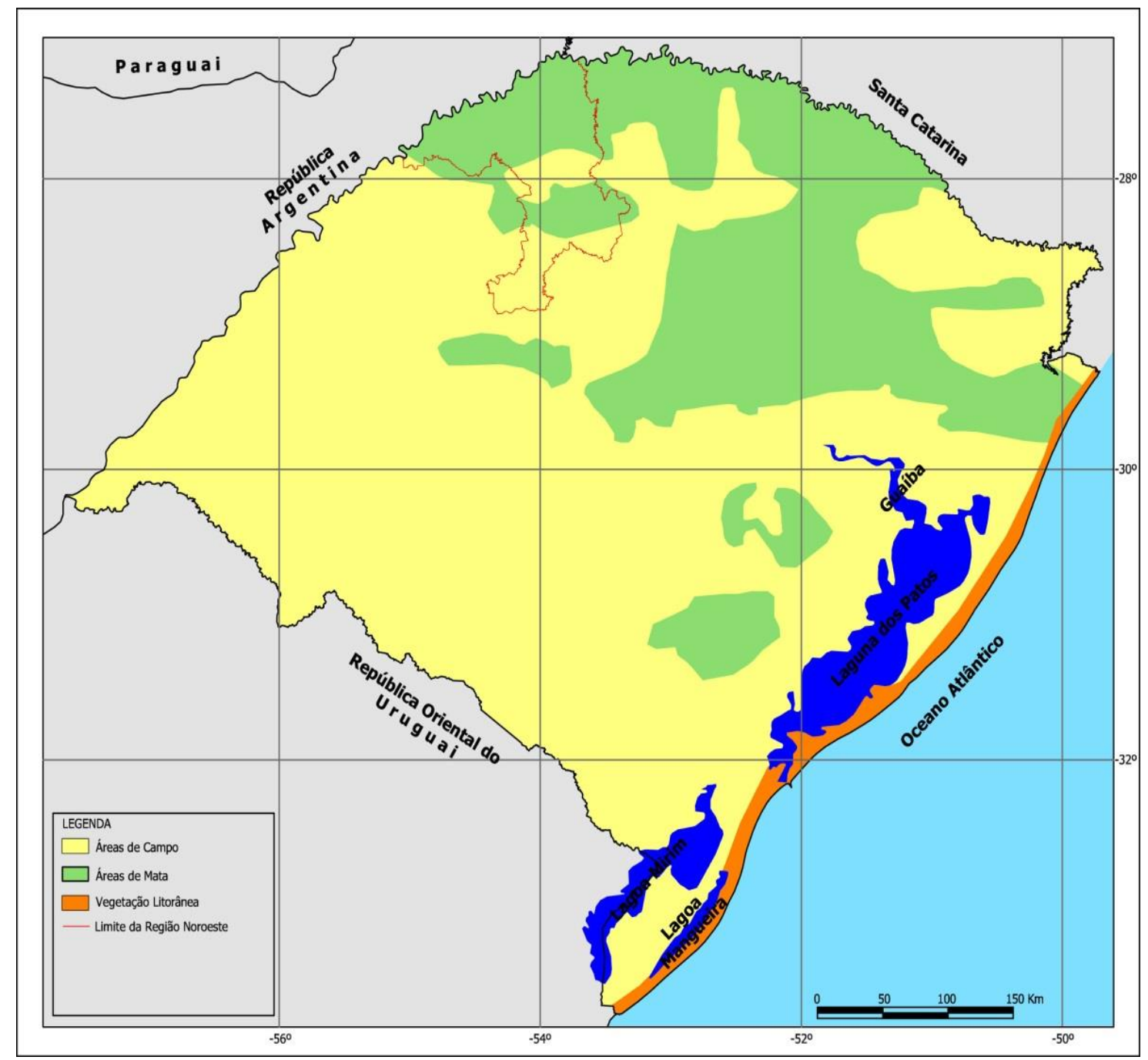

Figura 4.2.1. Vegetação original no RS. A entonação verde distingue as matas, em amarelo os campos e em laranja, a vegetação litorânea.

Fonte: Secretaria da Agricultura do RS, apud Bohn Gass et al., 2014 


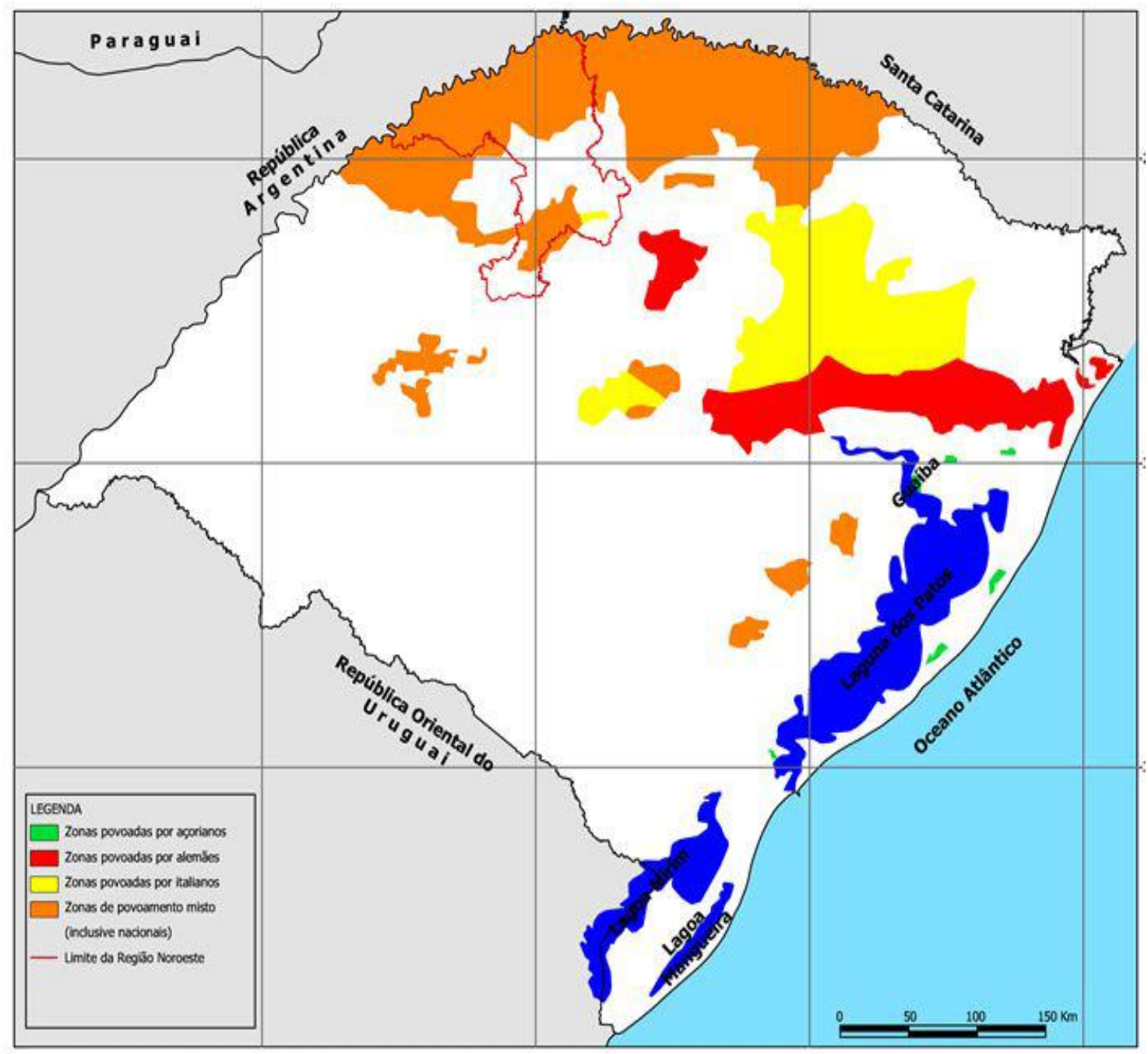

Figura 4.2.2. Zonas de povoamento no RS desde os açorianos do século XVIII.

Legenda: Cor verde: zona de povoamento açoriano; cor vermelha: zona de povoamento alemão; cor amarela: zona de povoamento italiana; cor laranja: zona de povoamento misto (inclusive os nacionais) e o traçado vermelho: limite estabelecido como Região Noroeste do RS.

Fonte: Secretaria da Agricultura do RS, apud Bohn Gass et al., 2014

Por ter um histórico essencialmente voltado para o meio agrário, a economia gaúcha só nas últimas décadas conseguiu equiparar os setores primário e secundário, antes amplamente dominada pelo primeiro. Nos anos de 1980 e ainda nos dias de hoje, encontra-se o contraste do espaço latifundiário, concentrado na região da fronteira (Uruguai e Argentina) e o espaço das pequenas propriedades, os minifúndios, predominante no planalto rio-grandense e suas encostas, visto pela Figura 4.2.3 (MOREIRA; COSTA, 1995). 


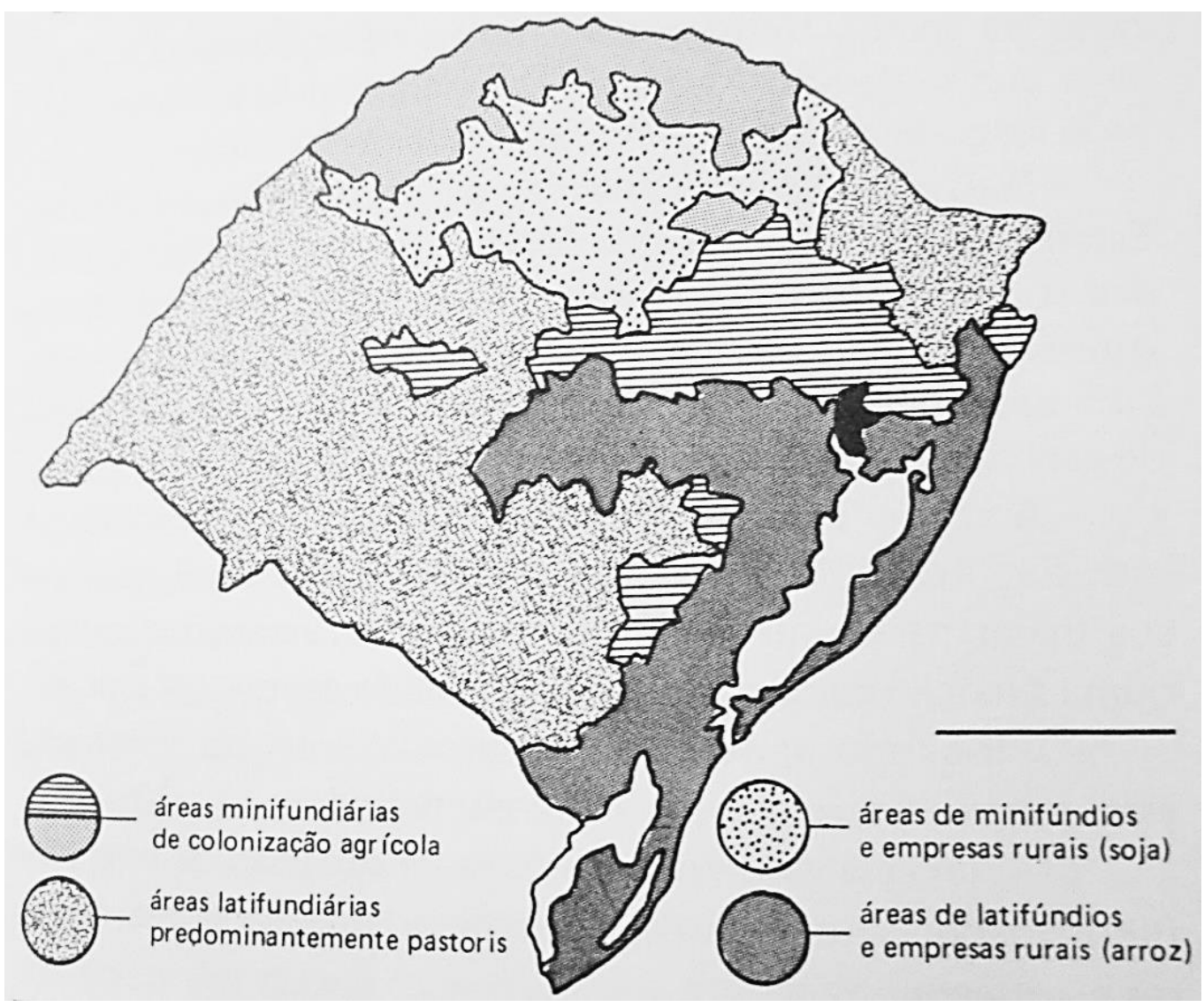

Figura 4.2.3. Estrutura fundiária no Rio Grande do Sul em 1980.

Fonte: Adaptado de KUCHERMANN, 1980, MOREIRA; COSTA, 1995.

Minifúndio, segundo o Art. 4, II do Estatuto da Terra, "é o imóvel rural de área e possibilidades inferiores às da propriedade familiar", ou seja, do "módulo rural ${ }^{27}$ ", que é “todo imóvel rural que, direta e pessoalmente explorado pelo agricultor e sua família, lhe absorve toda a força de trabalho, garantindo-lhe a subsistência, o progresso social e econômico, com área máxima fixada para cada região e tipo de exploração". O módulo rural varia de acordo com a região e o tipo de atividade. No RS, o módulo rural pode variar de 2 a 90 hectares, por exemplo, na Campanha gaúcha, para a criação de gado de grande porte, o módulo rural é de 70 hectares.

Os minifúndios no Estado do RS são mais numerosos, mas com área menor em comparação ao espaço latifundiário. De lotes iniciais entre 77,4 e 48,4 hectares, as

\footnotetext{
27 Módulo rural é uma unidade de medida agrária, expressa em hectares, que busca refletir a interdependência entre a dimensão, a situação geográfica e as condições de aproveitamento econômico do imóvel rural.
} 
propriedades coloniais passaram a 35/30 ha, em 1892, fixando-se definitivamente em 25 ha no final do século XIX. Com a migração e o fracionamento por sucessão hereditária, os minifúndios puderam se tornar ainda menores, com propriedades agrícolas em torno de 5 ha (MOREIRA; COSTA, 1995). Com tais dimensões, essas propriedades podem ser consideradas verdadeiramente minifúndios uma vez que são inferiores ao módulo rural regional do Noroeste (15 hectares) e, em consequência, demasiadamente pequena para uma família ter perspectiva de prosperar na atividade agrícola.

Alguns estudiosos argumentam a superioridade da grande sobre a pequena propriedade rural, no entanto, não se ignoram as vantagens tanto de uma como de outra e não existem dimensões ideais, podendo variar, principalmente, de acordo com a sua eficiência produtiva. Contrapondo-se a Guimarães (1989), de que a grande propriedade se baseia na produção de exportação e a pequena, na produção de subsistência, a Região Noroeste do Rio Grande do Sul apresenta uma organização produtiva de caráter comercial independente das dimensões das propriedades (MANTELLI, 2006).

Nesse sentido, concorda-se com os estudos de Veiga (1991), quando defende que o tamanho da unidade produtiva não é a questão mais relevante. A viabilidade econômica, principalmente das pequenas propriedades do Noroeste, mais do que a dimensão, está relacionada à possibilidade de introduzir tecnologias que proporcionem o aumento da produtividade, a conservação da qualidade do solo e das condições naturais, a definição do(s) tipo(s) de produto(s) a ser cultivado(s).

A porção Noroeste do Rio Grande do Sul pode ser classificada em duas áreas distintas sob os aspectos da estrutura fundiária (Figura 4.2.3) e do relevo (Figura 4.2.4 e 4.2.5): a região ao longo do curso do Rio Uruguai, caracterizada por relevo acidentado e solo menos propício à moto mecanização, onde predomina a pequena propriedade e a área de planalto (100 a 500 metros), com relevo propício para as culturas mecanizadas e maior concentração de terras por unidade de produção. Essa última área é a que, mesmo respondendo pelo maior volume de produção agrícola, é a que mais se aproxima dos interesses do desenvolvimento na visão tradicional, sendo, portanto, sua lógica de produção menos aberta à formulação de novas concepções de desenvolvimento localmente estimuladas. Porém a participação desse setor é fundamental na construção de maior dinamismo através de novas combinações entre rural e urbano (ROHLEDER, 2003, p. 62). Conforme verificado no mapa do macrozoneamento gaúcho (Figura 4.2.5), o Noroeste é caracterizado como área agrícola de uso intensivo no verão e inverno (Agrícola 2). 


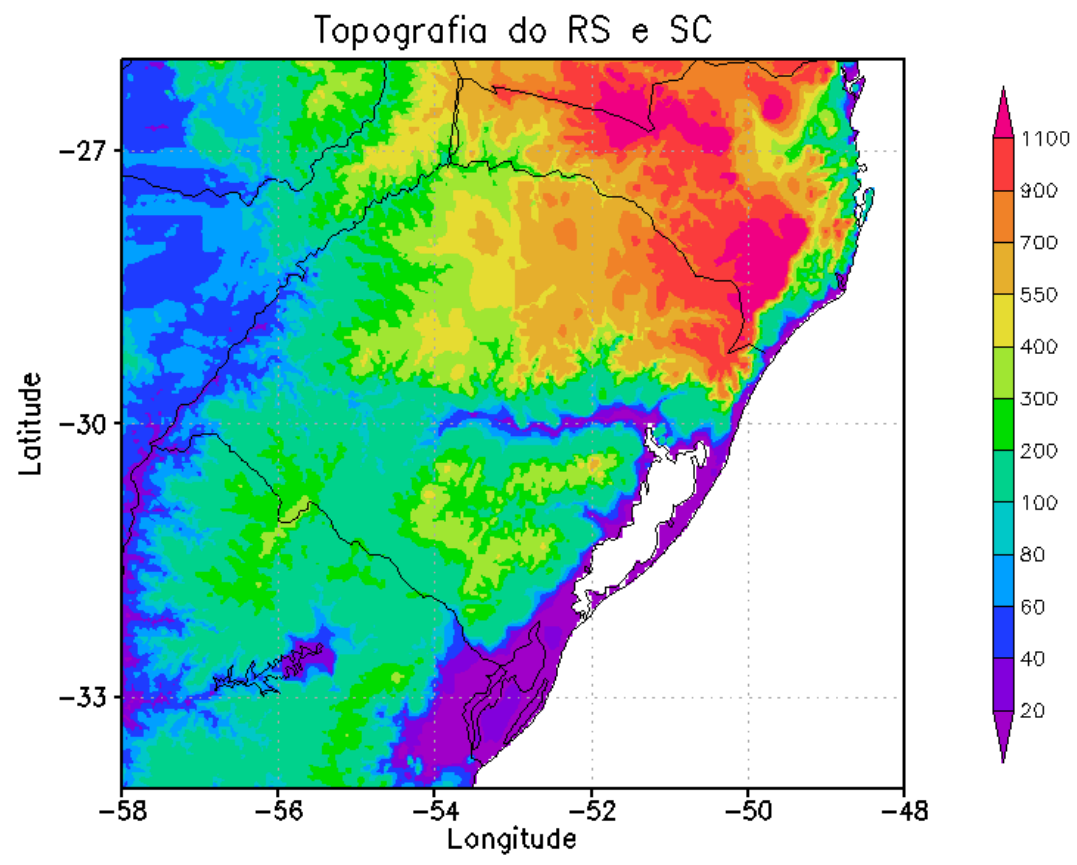

Figura: 4.2.4. Topografia do Rio Grande do Sul e de Santa Catarina.

Fonte: $\mathrm{O}$ autor

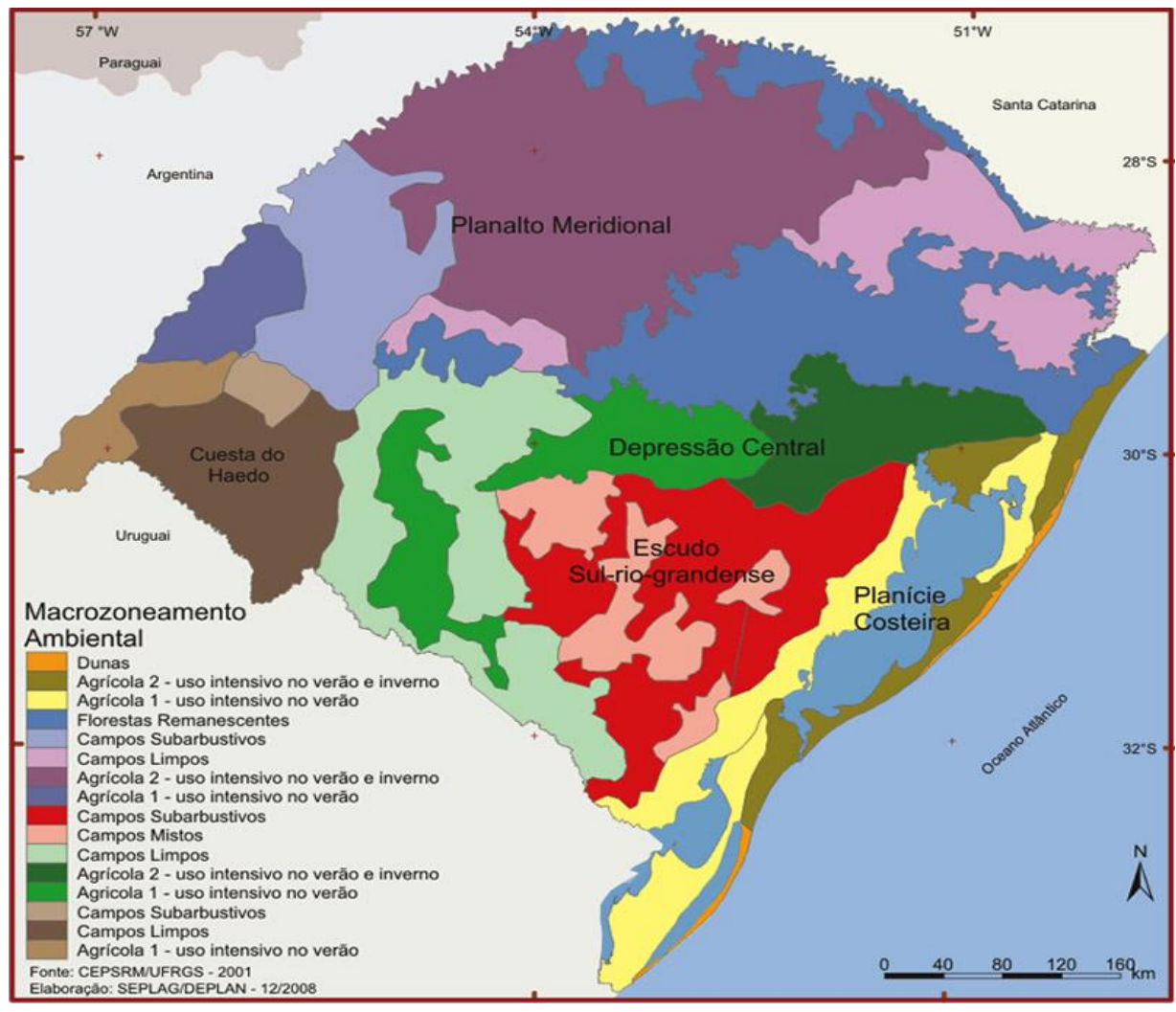

Figura 4.2.5. Relevo e macrozoneamento ambiental do Rio Grande do Sul.

Fonte: SEPLAG/DEPLAN, 2014. 
Os agricultores que ocuparam as fronteiras agrícolas restantes do Estado, em pouco tempo, transformaram em lavouras o que ainda restava das florestas. $\mathrm{O}$ desflorestamento ocorrido se deve ao fato de existir a necessidade de obter terras férteis a baixo custo econômico, não havendo grandes preocupações com a preservação do meio ambiente. A partir da década de sessenta e, com maior intensidade, na década de setenta, começam a ocorrer mudanças nas tendências do desenvolvimento agrícola, resultantes de vários fatores, como condições favoráveis no mercado internacional e aumento na demanda interna, forçando, de certa forma, um incremento na produção agrícola, superior às possibilidades de crescimento, através da simples expansão da área cultivada. Os agricultores ocuparam as fronteiras agrícolas restantes do Estado, transformando, em pouco tempo, o que restou das florestas, em lavouras.

De modo geral se considerar as propriedades rurais do Noroeste do RS, elas são predominantemente pequenas, por isso, os agricultores são ainda obrigados a optar pela variedade de produção, que serve principalmente para comércio, principalmente no que se refere à produção leiteira e de grãos. O Noroeste possui áreas plantadas com diversas culturas; no entanto, a soja detém a maior área cultivada, seguida do milho e do trigo e de outras culturas como batata, mandioca, hortaliças e frutas, que ocupam áreas bastante inferiores em comparação às três primeiras culturas (FEE, 2013, FIDENE, 1993).

Na região mais de $90 \%$ dos estabelecimentos têm área inferior a 50 ha (IBGE, 1995). Entre os anos de 1970 e 1995 os estabelecimentos com menos de 10 ha participam de forma muito significativa para o Noroeste do RS, com média de 40,18\% dos estabelecimentos, ocupando 10,42\% do total da superfície regional. Em 1995, observa-se um predomínio de estabelecimentos no intervalo 10-20 ha, ao redor de $33,18 \%$; e de $21,02 \%$ no intervalo $20-50$ ha (Tabela 4.2.1). A presença das consideradas grandes propriedades, com área superior a 100 ha, se dá de forma pouco expressiva, se considerado o número de estabelecimentos (em média $1,81 \%$ do total dos estabelecimentos em 1995) embora ocupem 25,90\% da área dos estabelecimentos regionais (Tabela 4.2.1) (MANTELLI, 2006). 
Tabela 4.2.1. Estrutura fundiária (\%) de estabelecimentos e de suas áreas no Noroeste do Rio Grande do Sul em 1970 e 1995.

\begin{tabular}{|c|rc|cc|}
\hline Anos & \multicolumn{2}{|c|}{1970} & \multicolumn{2}{c|}{1995} \\
\hline Classes & \multicolumn{2}{|c|}{ Estabelecimentos / Area } & Estabelecimentos / Área \\
\hline$<10$ & 42,13 & 11,62 & 40,18 & 10,42 \\
\hline $10-20$ & 34,79 & 27,81 & 33,18 & 22,82 \\
\hline $20-50$ & 19,84 & 32,14 & 21,02 & 28,76 \\
\hline $50-100$ & 2,16 & 8,23 & 3,68 & 12,10 \\
\hline$>100$ & 1,08 & 20,18 & 1,81 & 25,90 \\
\hline
\end{tabular}

Fonte: IBGE/Censos Agropecuários do RS, apud MANTELLI, 2006.

Nesse período houve a tendência em direção à concentração de terras na Região Noroeste. Nos dois primeiros estratos de área analisados (menos de 20 hectares e de 20 a 50 hectares), ocorre uma diminuição no número de estabelecimentos em quase todos os municípios que compõem a região. Porém, nos estratos de área maiores (50 a 100 hectares e mais de 100 hectares), há um aumento do número de estabelecimentos e consequente aumento da área, na grande maioria das unidades político-administrativas.

$\mathrm{Na}$ atual organização da estrutura regional denota-se um novo padrão fundiário, partindo do princípio de que, em termos conceituais, pequena, média e grande propriedades assumem conotação diferenciada, de acordo com as características de cada lugar, seja nos aspectos físicos, seja nos econômicos (MANTELLI, 2006). Para os padrões do noroeste gaúcho podem ser classificadas como pequenas propriedades as áreas inferiores a 50 ha; médias propriedades, as áreas entre 50 e 100 ha; e grandes propriedades, as áreas superiores a 100 ha. Conforme é observado na figura 4.2.6, o número de estabelecimentos rurais na agricultura familiar na porção Noroeste do RS gira ao redor dos intervalos de 3 até 2.000 estabelecimentos. A presença dessa modalidade rural familiar é mais marcante na metade norte do Estado 


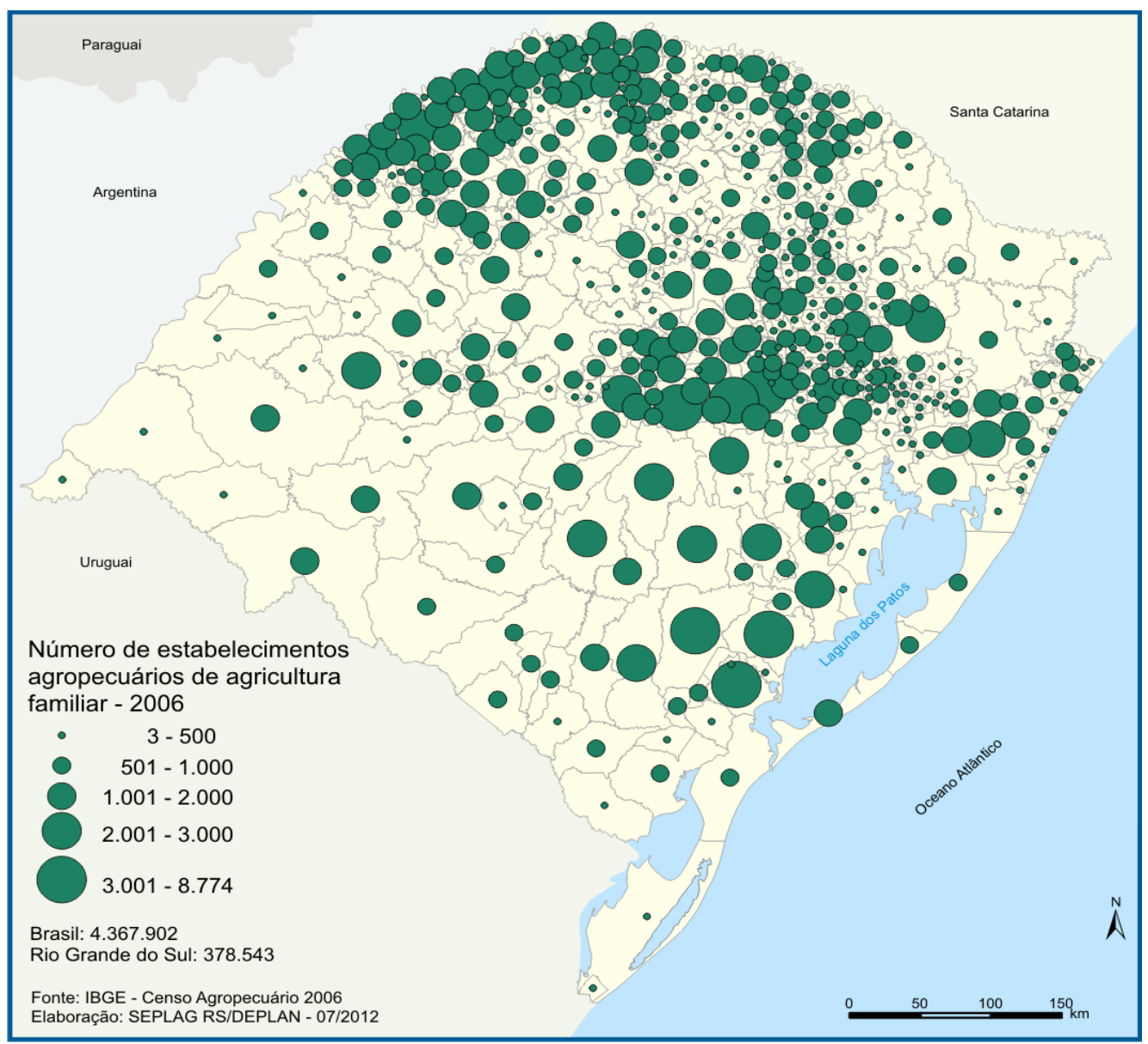

Figura 4.2.6. Número de estabelecimentos rurais de agricultura familiar em 2006. Fonte: IBGE, 2014.

Em termos regionais, o comportamento da estrutura fundiária no Noroeste do RS, entre as décadas de 1970 e 1995 direciona-se a uma diminuição no número de estabelecimentos com menos de 50 ha e a um aumento no número de estabelecimentos com mais de 50 ha de área como informa a tabela X. A adaptação da estrutura fundiária ao contexto em transformação trouxe a união de propriedades.

Fatores como o menor ou maior acesso às instituições financeiras, possibilidades de transferência de recursos disponíveis em outros ramos de negócios, etc. são elementos decisivos na determinação da sobrevivência e expansão ou da venda das propriedades (MANTELLI, 2006).

Através da incorporação das pequenas, com as médias e grandes propriedades cria-se o processo de ampliação no tamanho das propriedades rurais obtidas pela compra da terra dos produtores com menor área e com menos condições de se manterem 
no setor agrário. Nesse sentido, pode-se aceitar que há um crescimento em direção à concentração de terras na Região Noroeste. A desigualdade de condições dos pequenos proprietários em incorporar melhorias técnicas em suas terras em determinado momento tornam a junção com áreas maiores inevitáveis.

A formação da estrutura fundiária da região de estudo está estreitamente associada ao processo de ocupação, podendo ser consideradas a instalação de imigrantes em pequenos lotes e a forte capacidade de expansão das famílias descendentes como fatores indutores do quadro fundiário vigente. As propriedades foram subdividindo-se ao longo do tempo em virtude das partilhas por herança, em que um pedaço de terra constituía-se no único bem disponível para passar aos filhos. Como complemento, as técnicas de preparação do solo, cultivo e colheita, resultantes da experiência, eram transmitidas de uma para outra geração, que lentamente foram aperfeiçoando-se e tornando o trabalho menos penoso (BRUM, 1988).

É verificado no mapa o número de estabelecimentos agropecuários de agricultura não familiar em 2006 através da figura 4.2.7. Essa modalidade fundiária nos diversos municípios do Noroeste rio-grandense varia entre os intervalos $2-100$ e $101-$ 200 estabelecimentos. Em Santa Rosa, em 2006, é registrado o intervalo $101-200$ estabelecimentos rurais não familiares, conforme atesta o censo do IBGE (2014).

De modo geral, o número de pequenos estabelecimentos fundiários existentes na porção noroeste gaúcha participa de uma forma significativa em comparação à parcela relativamente pequena de sua área dentro do contexto estadual, o que a caracteriza como um espaço típico de pequenas propriedades. Por outro lado, principalmente na porção metade sul do Estado do RS, o destaque é a existência de grandes propriedades, dedicadas às pastagens e às lavouras de cunho comercial (Figura 4.2.6 e 4.2.7). 


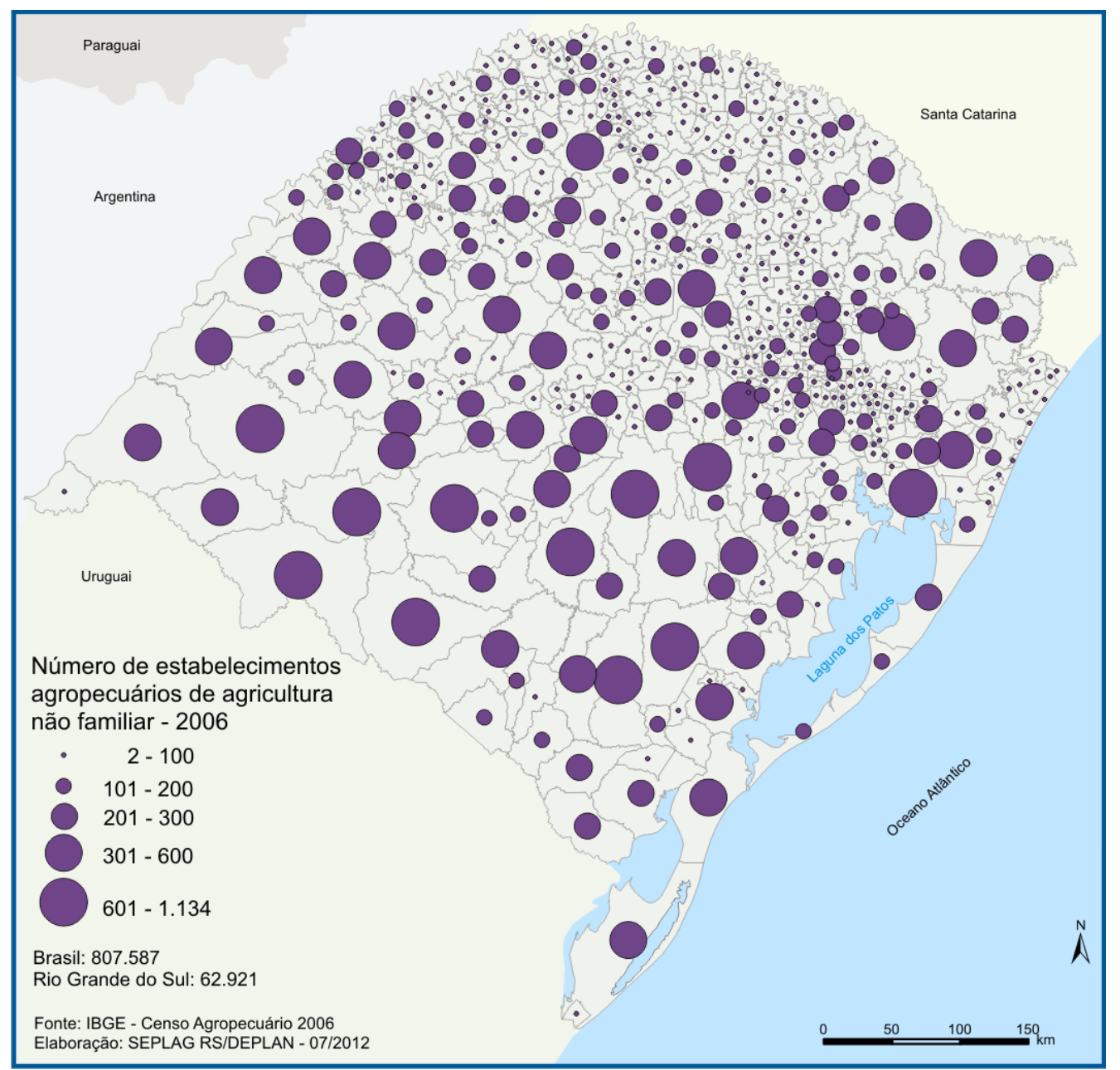

Figura 4.2.7. Estabelecimentos agropecuários latifúndios (não familiares), em 2006.

Fonte: IBGE, 2014

\subsection{PRODUTIVIDADE AGRÍCOLA}

A ideia de "cadeia" permite o entendimento da ligação entre os diversos setores envolvidos na produção de culturas agrícolas, a exemplo da soja com o mercado. A cadeia produtiva pode ser definida como um recorte dentro do complexo agroindustrial mais amplo, privilegiando as relações entre a agricultura, a pecuária, a indústria de transformação e a distribuição em torno de um produto principal. Trata-se então de um processo sequencial de operações interdependentes cujo objetivo é produzir, modificar e distribuir um produto até seu consumidor final (FARINA; ZILBERSZTAJN, 1991, apud ROTTA, 1999).

A soja em escala comercial iniciou-se em Santa Rosa a partir de 1935, quando o cultivo encontrava-se pouco mais intensificado, antes, no entanto, era empregada 
essencialmente como forragem para a criação de animais. Na década de 1940, a soja permanece tendo um papel secundário na atividade agrícola, suplantada pelas culturas de milho e mandioca. Nos anos de 1950, tem-se um acentuado incremento na produção do grão com a expansão além da região de Santa Rosa (CHRISTENSEN, 2004, p. 201).

Na década de 1960, o Instituto Nacional de Colonização e Reforma Agrária INCRA, ciente das deficiências estruturais dos solos agriculturáveis das regiões coloniais, em virtude dos seus esgotamentos, selecionou no Sul do Brasil, municípios cujo desenvolvimento deveria servir de modelo para outros municípios. A primeira região onde foi implantado o Projeto Estadual de Melhoramento da Fertilidade dos Solos (mais tarde denominada Operação Tatu) foi Ibirubá, depois Santa Rosa, Ijuí e Erechim (Christensen, 2004, p. 247). Atendendo ao chamado do governo de "produzir mais para exportar", o apoio do governo era uma medida para garantir excedentes comerciais e com isso o pagamento das importações de petróleo e a obtenção de uma maior tecnologia, condições importantes no processo de industrialização à época:

Apostava-se na modernização da agricultura e, rapidamente, a cultura do grão se torna o primeiro produto agrícola do Estado a somar divisas nas exportações. Desse modo, a soja passa a ser um produto especializado na cultura gaúcha, o milho vai para um plano secundário e o trigo ganha o status de cultura melhor trabalhada depois do advento da lavoura da soja (CHRISTENSEN, 2004, pp. 201-202).

A partir de meados dos anos de 1960, impulsionada pela política de subsídios ao trigo visando à autossuficiência nacional, a soja se estabeleceu como cultura importante no contexto brasileiro. Naquela época conforme salienta Christensen $(2004$, p. 201) a produção saltou de 206 mil para 1.056.000 toneladas no ano de 1969, registrando que 98\% desse volume foi produzido nos Estados do Rio Grande do Sul, de Santa Catariana e do Paraná, onde se intercalava o cultivado do trigo na estação de inverno e da soja no verão.

A necessidade de aumentar a exportação de produtos agrícolas e de matériasprimas provocou a reformulação da política agrícola que possibilitou tanto a expansão das indústrias de bens de consumo duráveis e de capital, como a expansão da soja. Entre os anos de 1968 e 1975, a soja apresentou um aumento de quase seis vezes na área plantada e mais de dez vezes na quantidade produzida. Dessa forma, a soja passa à liderança no processo de acumulação na agricultura do Estado do RS (FEE,1978, p. 91). 
A agricultura no Estado, sempre manteve uma posição de destaque na produção nacional de diversas culturas (soja, milho e trigo). No auge da produção de soja, nos anos de 1970, o RS obteve uma participação de $19 \%$ da produção primária nacional. Não obstante as experiências anteriores, registradas em outros estados brasileiros, foi nesse Estado que a soja começou a ser cultivada em escala maior (CARRION JR. 1986).

Produzida comercialmente no Brasil a partir de meados de 1960, a cultura da soja assumiu na década de 1970 papel preponderante na chamada modernização da agricultura do Noroeste do RS. Sua produção que inicialmente veio como complemento ao trigo e concorrente ao milho transformou a economia da região de tal forma que passou a liderar a geração de renda local, sendo acompanhada pelo milho no verão, em segundo plano, e situando a economia do trigo em posição efetivamente secundária, tanto que a partir de 1980 o trigo deixou de ser privilegiado pelas políticas comerciais e de apoio oficiais (BRUM et al. 2008, p. 148).

A produção de soja corresponde à terceira atividade agropecuária que mais contribuiu para o crescimento do valor bruto da produção agropecuária (VBPA) do RS entre os anos de 1970 e os anos finais da década de 1990. Seu desempenho foi decisivo para o resultado geral e especialmente importante para os municípios em que sua expansão foi mais acentuada. No início do período citado, na década de 1970, a produção de soja estava concentrada na região de planalto rio-grandense, com destaque para os municípios de Passo Fundo, Santo Ângelo, Palmeira das Missões, Cruz Alta e Giruá pelo montante de produção, e para os municípios de Tapera, Não-me-Toque, Colorado, Selbach, e Miraguaí, pela densidade de produção por $\mathrm{Km}^{2}$ (TRENNEPOHL et al. 2008, p. 199).

A expansão da cultura da soja foi muito rápida, ampliando significativamente os horizontes da região produtora e intensificando a produção dos municípios pioneiros. Todavia, em 1996, os municípios localizados na metade norte do RS, mais a Noroeste, assumiram destaques na produção de soja, tais como Cruz Alta, Palmeira das Missões, Passo Fundo e Tupanciretã, pelo volume total, e os municípios de Pejuçara, Sertão, Chiapeta, Santa Bárbara do Sul e Colorado, pela densidade de valor por $\mathrm{Km}^{2}$ (TRENNEPOHL et al. 2008, p. 199).

Nos mapas das figuras 4.3.1 e 4.3.2 observa-se que a maior produtividade agrícola da soja se dá entre os municípios da porção norte-oeste (noroeste) do Estado com destaque para Cruz Alta, Ijuí e Passo Fundo entre o ano de 1998 e 2000 (a) em 
detrimento da porção sul, ao passo que, entre os anos de 2004 e 2006 (b), há certo deslocamento entre alguns municípios do Norte para áreas do Sul do Estado, os quais deixam de produzir como no período anterior, a exemplo de Santa Rosa. Tais disparidades temporais de produtividade entre os dois períodos devem-se a causas distintas, como os fenômenos climáticos extremos, o esgotamento dos solos agrícolas, ou mesmo à redução das áreas destinadas à produção agrícola.

A soja deixa de ser produção essencialmente do Rio Grande do Sul e avança pelo Brasil, levada pelo sonho de progresso de agricultores que deixam aquele Estado quando as terras esgotadas não mais atendem o sustento de inúmeras famílias. Nas novas localidades de plantio, o solo tratado faz a soja brotar novamente e multiplicar geometricamente sua produção na medida em que avançam as tecnologias de manejo e maquinário empregados desde o plantio até a colheita (CHRISTENSEN, 2004).

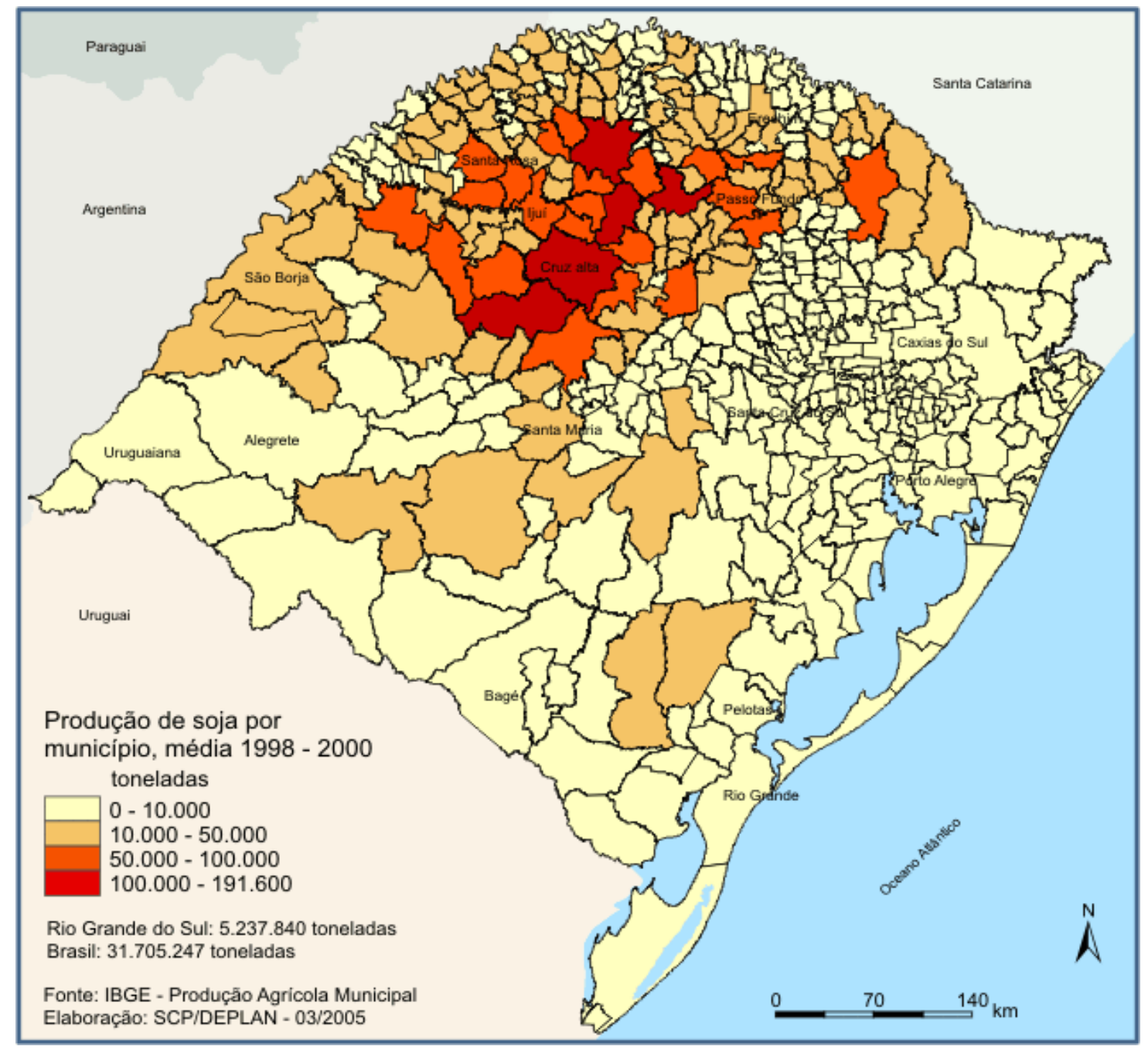

Figura 4.3.1. Média de produtividade de soja por município entre 1998 e 2000

Fonte: Fonte: Atlas Socioeconômico do RS, 2013. 


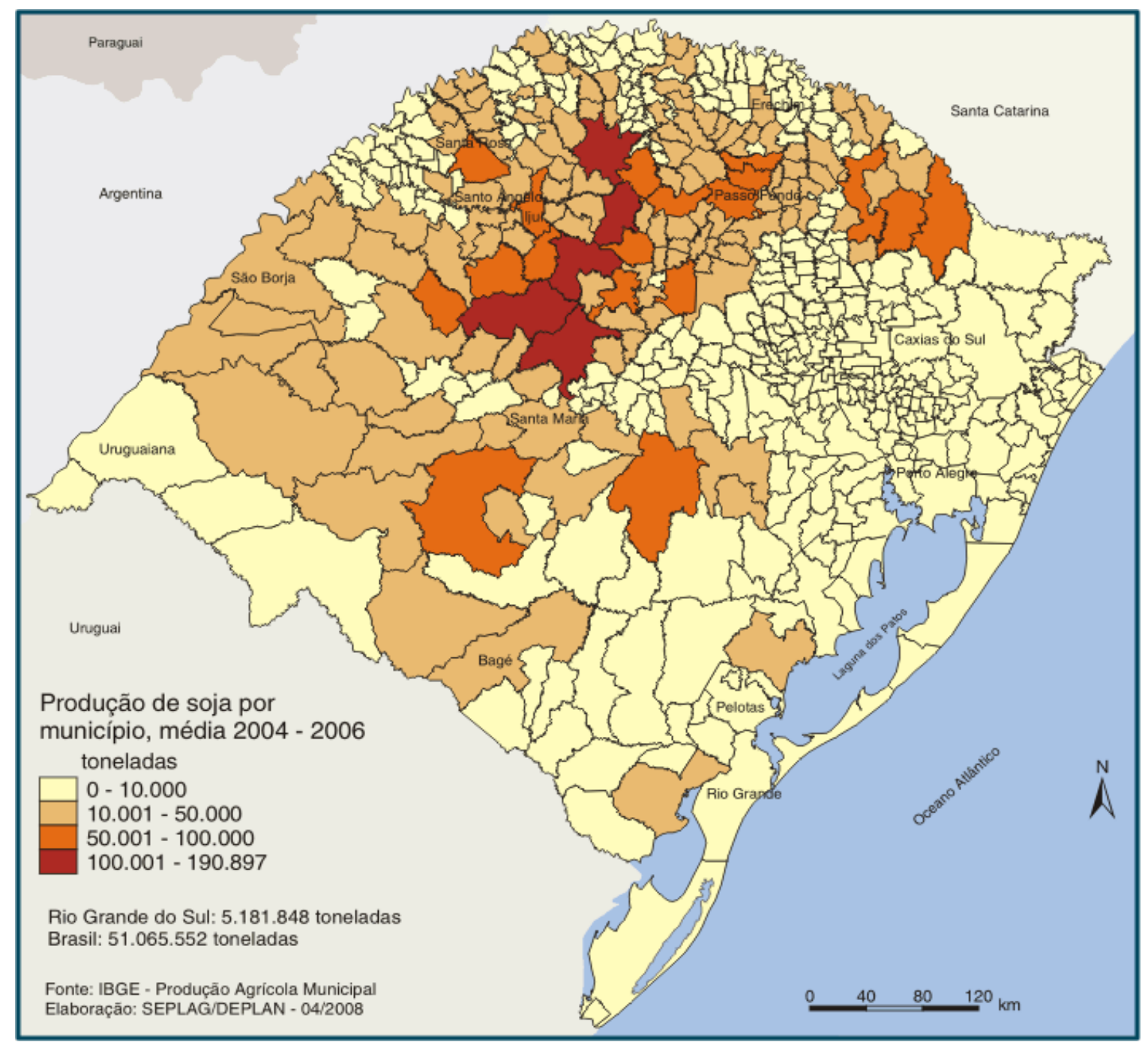

Figura 4.3.2. Média de produtividade de soja por município no RS entre 2004 e 2006.

Fonte: Fonte: Atlas Socioeconômico do RS, 2013.

A rota da soja espalhou pelo Brasil milhares de agricultores que, ao saírem do Sul em busca de terras acessíveis e estímulos governamentais para novas fronteiras agrícolas, iniciavam a exploração de grandes regiões interiores, como a região do Centro-Oeste por seu bioma típico de cerrado. A partir da década de 1980, a soja passa ser largamente produzida no Centro-Oeste e no Nordeste brasileiros (Figura 4.3.3 e 4.3.4), especialmente entre os Estados do Mato Grosso, Mato Grosso do Sul e Goiás que, pouco a pouco, igualam-se e, por vezes, suplantam a produção dos estados do Sul. 


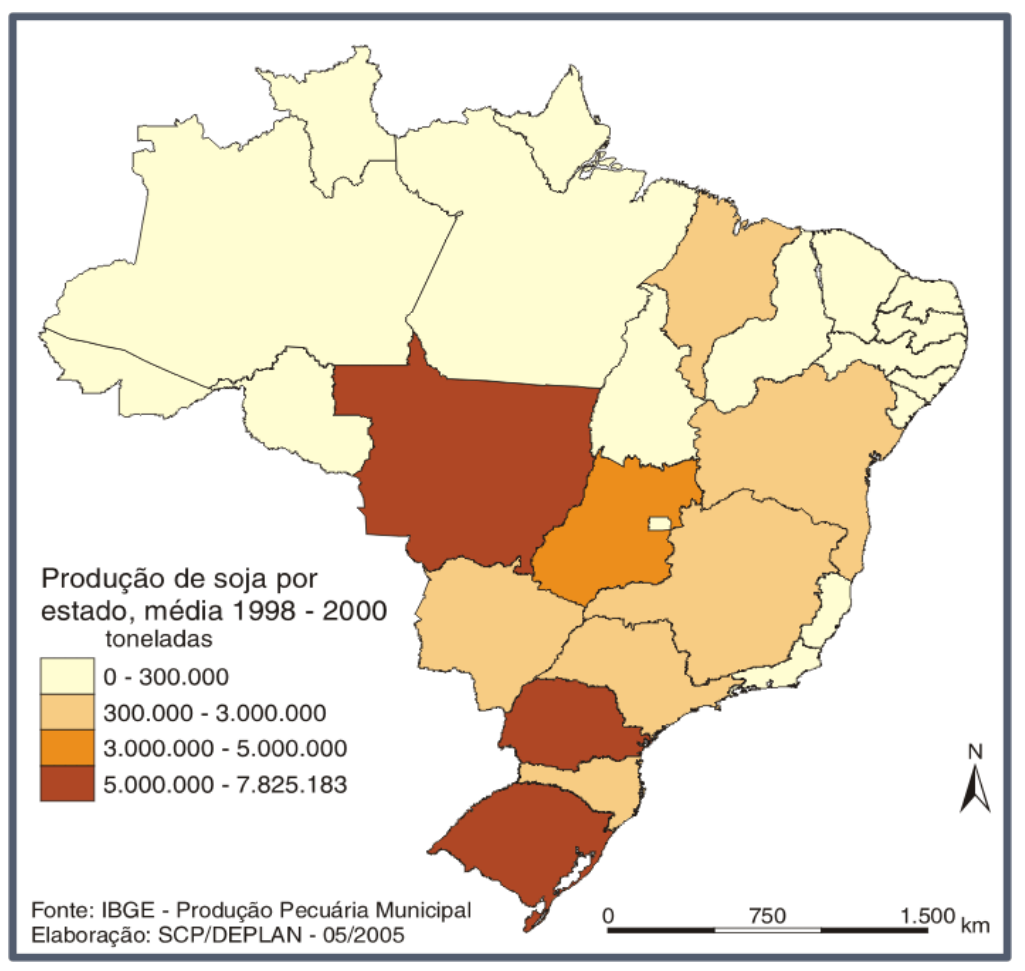

Figura 4.3.3. Produção de soja por estado, médias de 1998-2000

Fonte: Atlas Socioeconômico do RS, 2013.

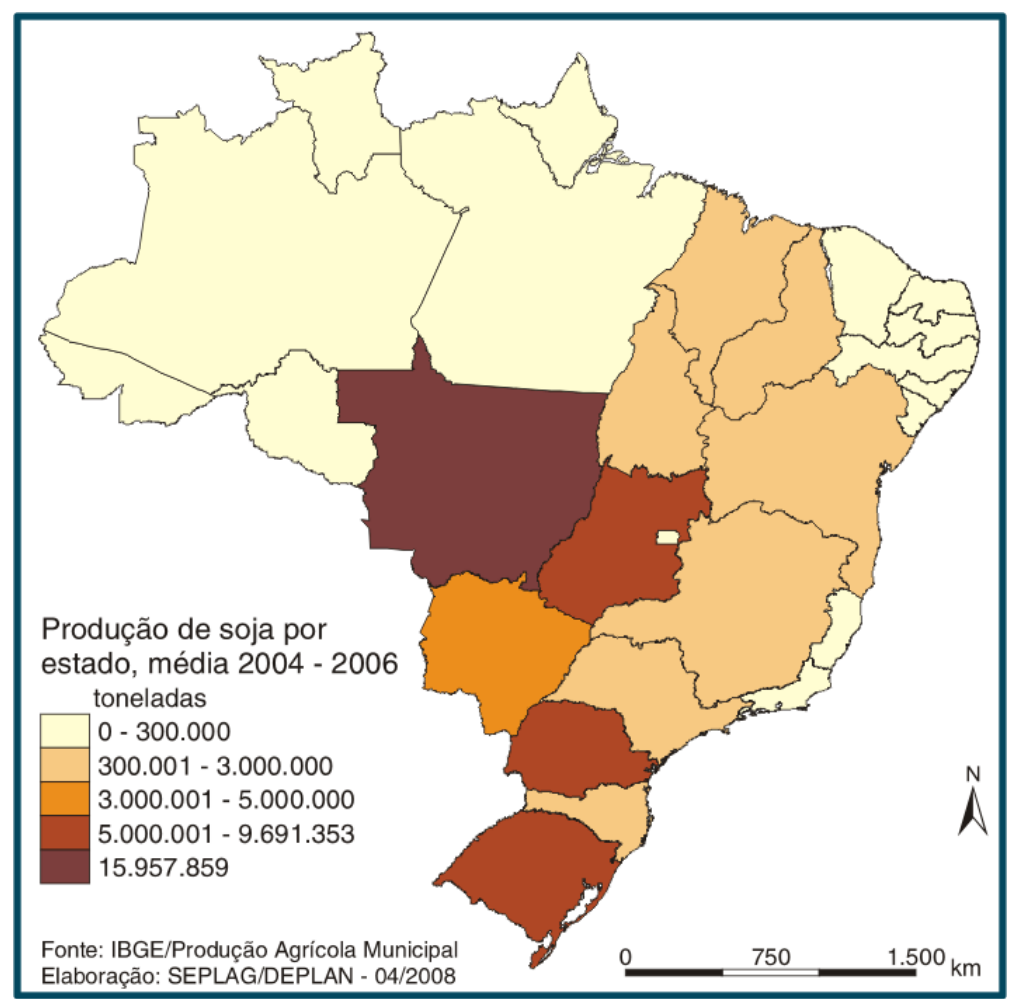

Figura 4.3.4. Produção de soja por estado, médias de 2004-2006 Fonte: Atlas Socioeconômico do RS, 2013. 
Os mapas anteriores evidenciam a produção de soja, em larga escala, entre o período de 1998 e 2006 nas Grandes Regiões Geográficas Sul, Sudeste, Centro-oeste e Nordeste do Brasil. Notável é a produção exibida pelo Estado do Mato Grosso em 1998/2000 e se sobressai ainda mais entre 2004 a 2006. Atualmente, o Centro-Oeste concentra a maior produtividade de soja no País, suplantando o Sul. A posição já foi do RS, que hoje ocupa a terceira colocação, vindo logo atrás do Paraná. Mato Grosso produziu 15 milhões de toneladas na safra 2006/2007, enquanto o Paraná respondeu por 12 milhões de toneladas e o RS, por 9 milhões. Juntos, os três estados mencionados representam 62\% do total nacional (BRUM, 2007, p. 179).

Fundamentalmente, a grande diferença da soja em relação às duas outras culturas típicas da Região Noroeste, o milho e o trigo, está no fato de que a oleaginosa sempre foi produzida visando, particularmente, o mercado externo à região, isto é, a economia regional encontrou num produto de exportação o seu elemento propulsor e de manutenção da geração de renda e desenvolvimento. A cultura da soja perdura nos dias atuais, embora tenha passado por transformações importantes em mais de quarenta anos de existência (BRUM et al. 2008, p. 148).

No RS, aproximadamente $80 \%$ da produtividade de soja provém da mesorregião Noroeste, e nessa área geográfica encontra-se a microrregião Fronteira Noroeste com uma participação de até 500.000 toneladas do grão, ou 5,6\% do total do Estado (Brum, 2007, p.179). Outras regiões gaúchas apresentam semelhança de perfil produtivo de soja em comparação ao Corede Fronteira Noroeste. Conforme apresenta a figura 4.3.5, aparentemente, o CRD Fronteira Noroeste parece ter a mesma média produtiva que outros no Estado, cuja média das safras de 2004 a 2006, fica em torno de 100.001 a 300.000 toneladas. 


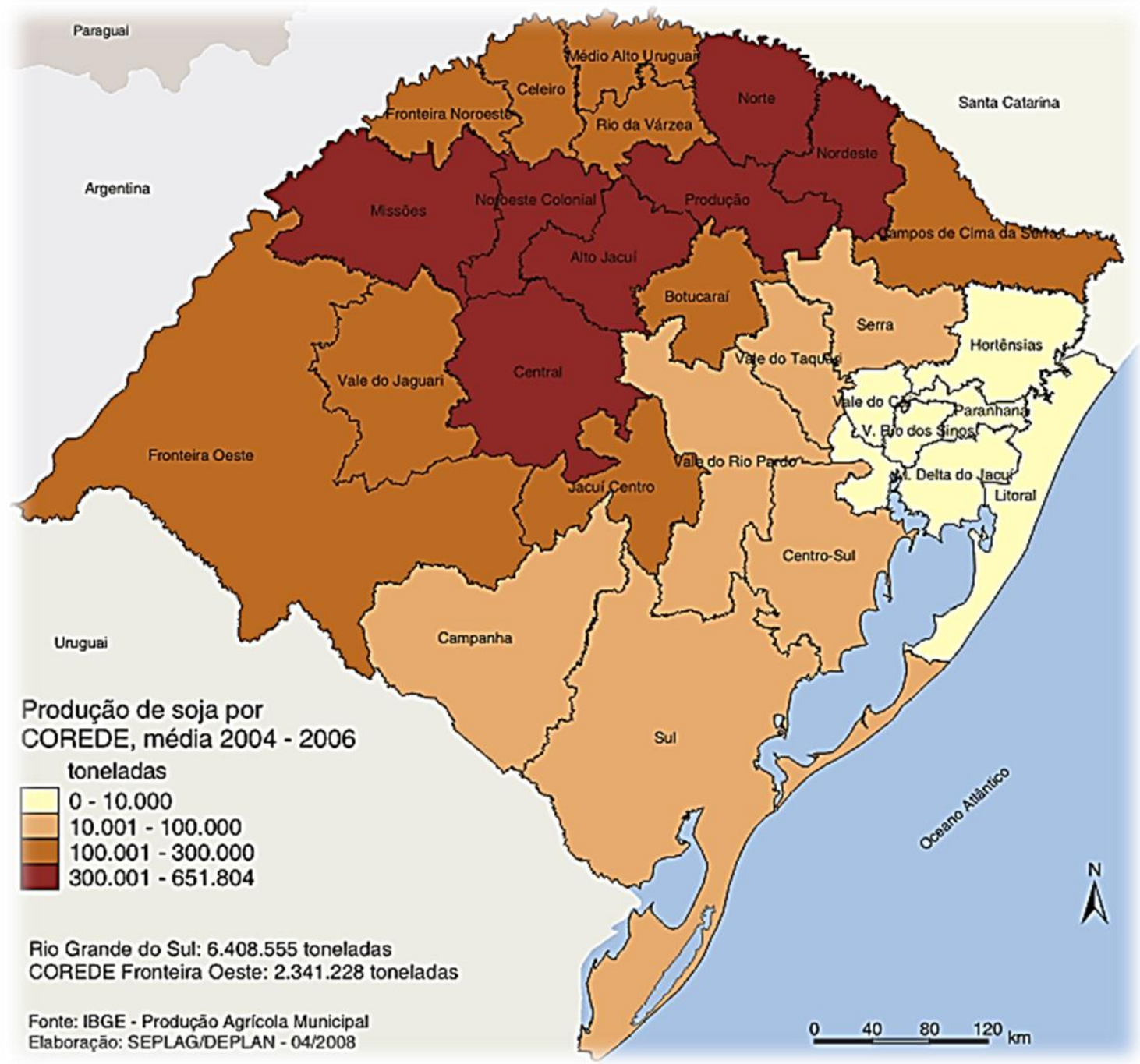

Figura 4.3.5. Produção de soja por Corede, média de 2004-2006.

Fonte: Atlas Socioeconômico do RS, 2013.

Uma explicação para justificar os dados anteriores deve-se ao fato de que o Corede Fronteira Noroeste vem sofrendo modificações na área do agronegócio. A principal modificação é a diversificação das atividades econômicas, que acompanha os avanços tecnológicos existentes no mercado, ao lado da diminuição sistemática da dependência em relação a uma única cultura, a soja. A diversificação modernizada, com forte presença tecnológica em busca de rentabilidade e escala de produção suficiente, visa manter as propriedades rurais das quais depende a economia regional. Brum et al. (2008, p. 149) dizem que "mesmo a soja tendo menor participação relativa, ela continua sendo o motor da economia regional".

Notadamente, a soja é a principal oleaginosa mundial, com significativa participação no mercado internacional devido ao farelo e ao aproveitamento de seu óleo 
para consumo humano. De cada grão triturado retira-se, em média, $78 \%$ de farelo e 18,5\% de óleo. Para Brum (2007, p. 178), a lógica do desenvolvimento regional passa pela consolidação da oleaginosa soja, associada a um forte sistema de diversificação modernizado com agroindustrialização dentro das áreas viáveis.

O mapa que segue salienta as propriedades com mais de 500 ha no RS, conforme dados do IBGE divulgados em 2006. Observa-se que a porção norte do Estado concentra menor quantidade desse perfil fundiário, ao passo que na porção centro-sul encontra-se uma maioria de módulos acima de 500 ha (Figura 4.3.6). Ao consideraremse o potencial da soja e a característica fundiária estadual, continua sendo mais interessante estimular a transformação do produto em farelo para produção de óleo para o consumo humano e ração do que a produção de biodiesel, de certa forma preterida na Região Noroeste do RS.

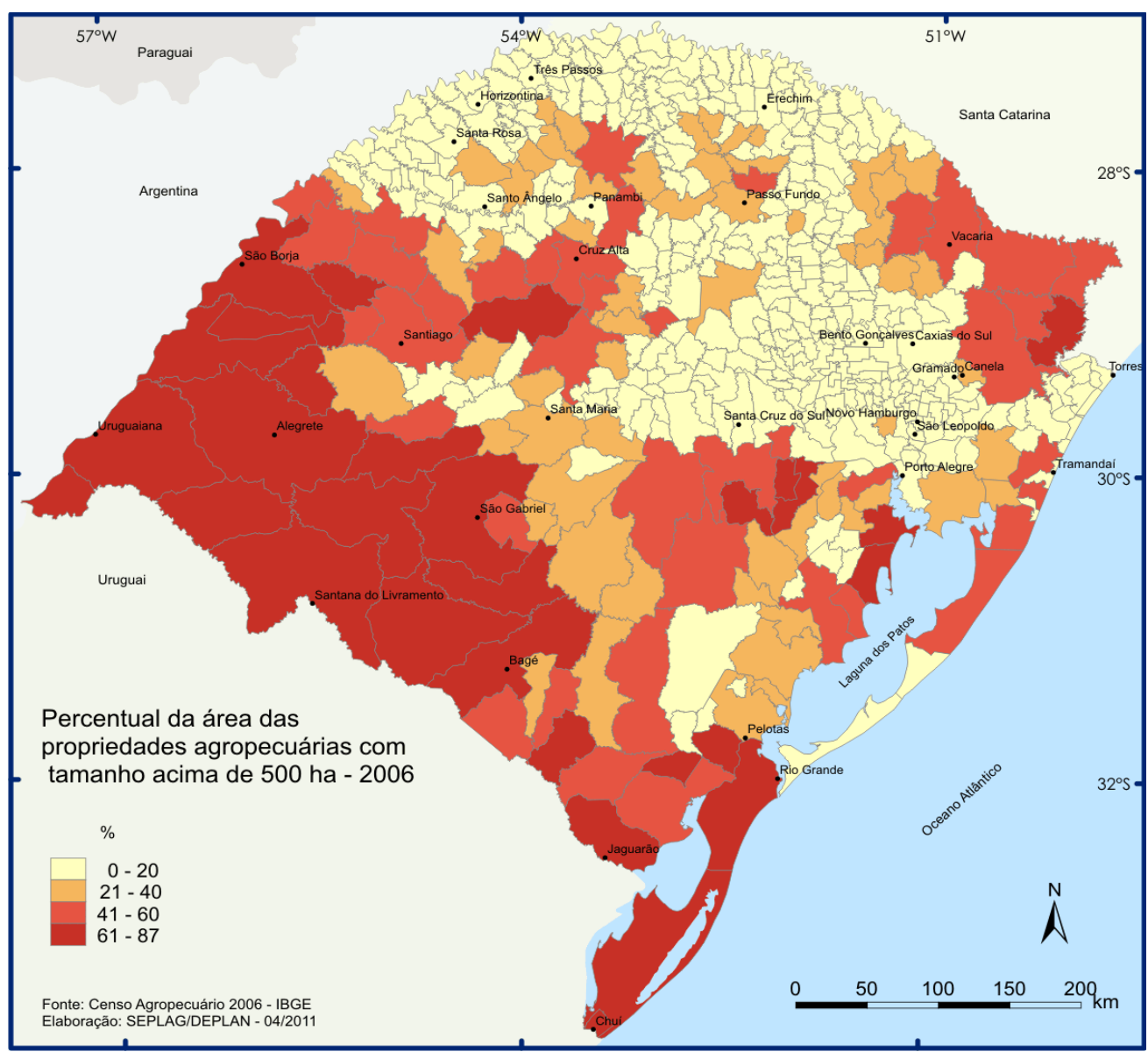

Figura 4.3.6. Percentual no RS com áreas superiores a 500 ha em 2006.

Fonte: Atlas Socioeconômico do RS, 2013. 
Conforme visto anteriormente, mais de $90 \%$ das propriedades agrícolas da Região Fronteira Noroeste possuem menos de 50 ha. Com a introdução da soja na década de 1950, foi desenvolvida uma estrutura industrial e comercial baseada na produção e exportação do grão, que modificou profundamente a região. Apesar do perfil de pequenas propriedades rurais cultivadoras de soja, o pioneirismo desse cultivo em Santa Rosa valeu-lhe em diferentes momentos os títulos de "Capital Nacional da Soja" e "Berço Nacional da Soja".

Os fornecedores de máquinas e equipamentos agrícolas, as empresas de armazenamento e prestadoras de serviços, as indústrias produtoras de insumos agrícolas, enfim, todos os negócios participantes da produção de soja são responsáveis pela maior parte do produto interno bruto (PIB) do Noroeste do RS. No complexo econômico regional, atualmente, a produção de soja é ainda tão significativa que ela representa mais de 50\% do conjunto da produção agrícola regional. No entanto, embora a estrutura produtiva da soja tenha proporcionado um progresso econômico ao Noroeste gaúcho, gerando empregos e serviços públicos em função de uma maior arrecadação de impostos, os maiores beneficiados ainda são as corporações multinacionais responsáveis pela exportação e o fornecimento de insumos como adubos químicos e agrotóxicos e as tecnologias agrícolas representadas pelas grandes montadoras de automotrizes e de tratores (ANDRIOLI, 2007).

Num estudo acerca da variabilidade interanual de precipitação pluviométrica e da produção de soja no RS consideraram os efeitos dos eventos de El Niño Oscilação Sul (ENOS) ${ }^{28}$ e concluíram que as chuvas no período de dezembro a março explicam cerca de $80 \%$ da variabilidade interanual da produção de soja. Com o El Niño, fase quente do fenômeno oceânico, de modo geral a cultura da soja é favorecida, ocasionando na maioria das vezes rendimentos recordes no Estado. Por outro lado, com o La Niña, fase fria do fenômeno oceânico, o efeito sobre o rendimento agrícola da soja é o oposto (BERLATO; FONTANA, 1999).

Períodos de estiagem, com baixos ou insignificantes volumes de chuva na estação chuvosa, que corresponde aos meses de outubro a março, no Noroeste do RS são conhecidos por veranicos (SLEIMAN, 2008). A Figura 4.3.7 evidencia um número expressivo de veranicos no primeiro e quarto trimestres de uma série histórica que inicia

\footnotetext{
${ }^{28}$ Ver Berlato, M. e Fontana, D. El Niño e La Niña. Impactos no clima, na vegetação e na agricultura do RS. Aplicações de previsões climáticas na agricultura. Porto Alegre: Ed. UFRGS, 2003.
} 
em 1978 e se estende até 2005. Tais fenômenos climáticos pronunciam-se mais no primeiro trimestre (janeiro a março). Observa-se na Figura que os círculos de coloração laranja indicam a atuação da fase quente do fenômeno oceânico ENOS, o El Niño. Já os anos com evidências de maior ocorrência do veranico estão estreitamente ligados com a atuação da fase fria, o La Niña, marcados com círculos de coloração azul.

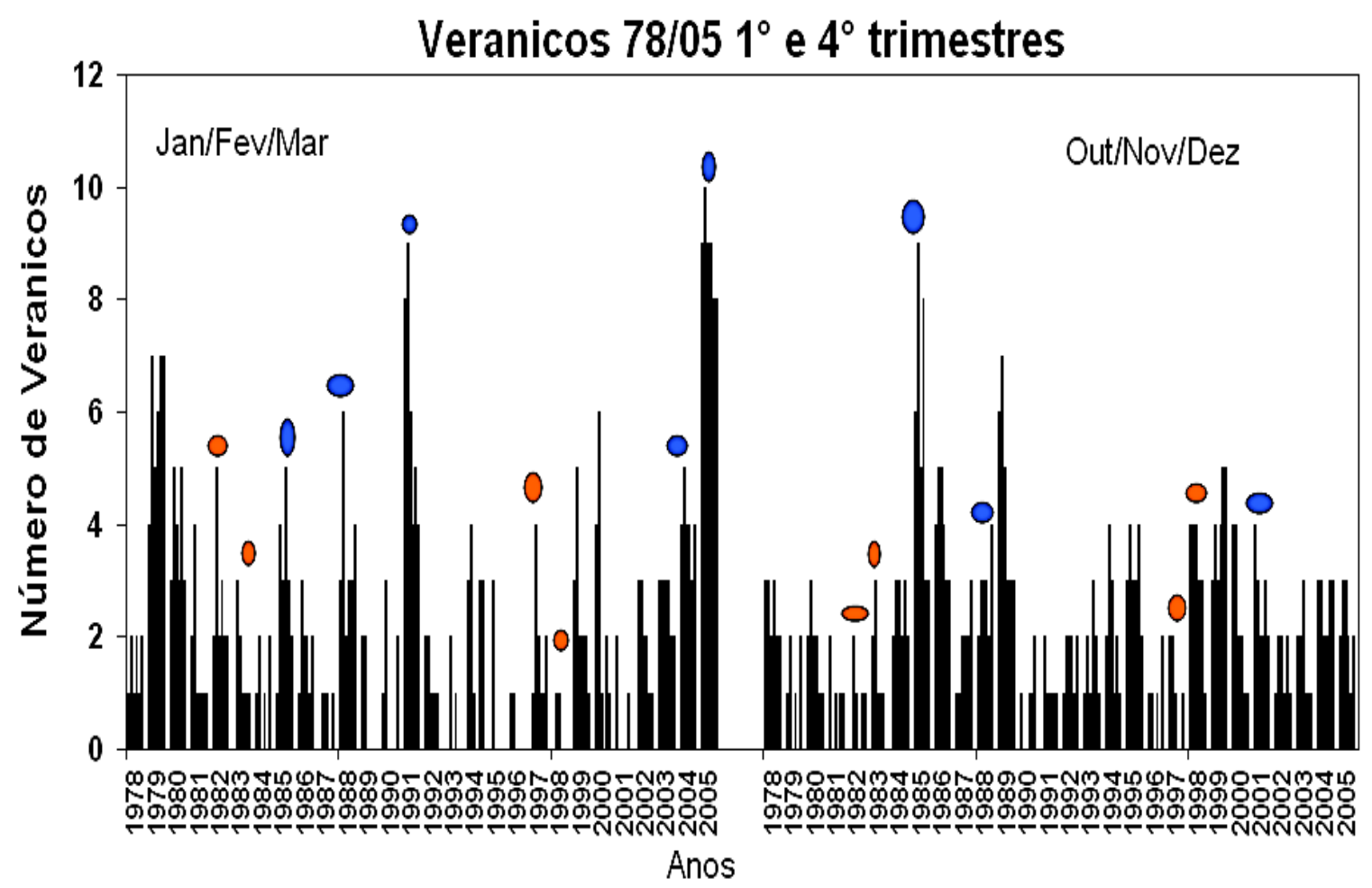

Figura 4.3.7. Períodos com eventos maiores e menores de veranicos (estiagens) entre 1978 e 2005, no Noroeste do RS. O círculo azul corresponde à atuação do La Niña e o círculo laranja, à atuação do El Niño no período.

Fonte: Sleiman, 2008.

Considerando que a produtividade das culturas de soja e milho é influenciada pelo clima, especialmente pela variabilidade do volume de chuvas durante seu ciclo produtivo, observa-se que a ocorrência de fenômenos meteorológicos interferem na produtividade dessas culturas (Figuras 4.3.7-4.3.9). Assim, através da confrontação dos dados de produtividade com os climáticos de ocorrência de veranicos, verifica-se que em anos de El Nino, quando há maior número de dias chuvosos, ocorre diminuição na ocorrência de veranicos durante o verão, o que contribui para o aumento da produtividade das culturas de soja e milho, ao passo que em anos de La Niña, quando a 
incidência de chuvas é menor, ocorre diminuição da produção nas lavouras em virtude do aumento do número de dias sem chuva.

Isso é bastante visível na cultura da soja (Figura 4.3.8) que é implantada a partir do mês de outubro e se estende até dezembro, quando o clima tem papel fundamental, principalmente nos meses de janeiro a março, período em que a cultura se encontra em estágios reprodutivos e a demanda por água aumenta. Por isso, nos anos de 1986, 1991 e 2005 (Figuras 4.3.7 e 4.3.8), em que o fenômeno La Niña foi acentuado, a produtividade da soja não alcançou $1000 \mathrm{~kg} / \mathrm{ha}$.

Na porção noroeste do RS, a soja, que teve expressão significativa a partir da segunda metade da década de 1960, consolida sua participação no decorrer das décadas de 1970 e 1980, concomitantemente ao aumento de sua área de colheita em 80\% (EMATER/RS, 2007). Mesmo com o aumento dessa produção, motivado por aspectos diversos, houve oscilações no decorrer dos anos, como na malfadada safra 2005 (Figura 4.3.8), seriamente afetada por seca que causou enormes dificuldades aos produtores.

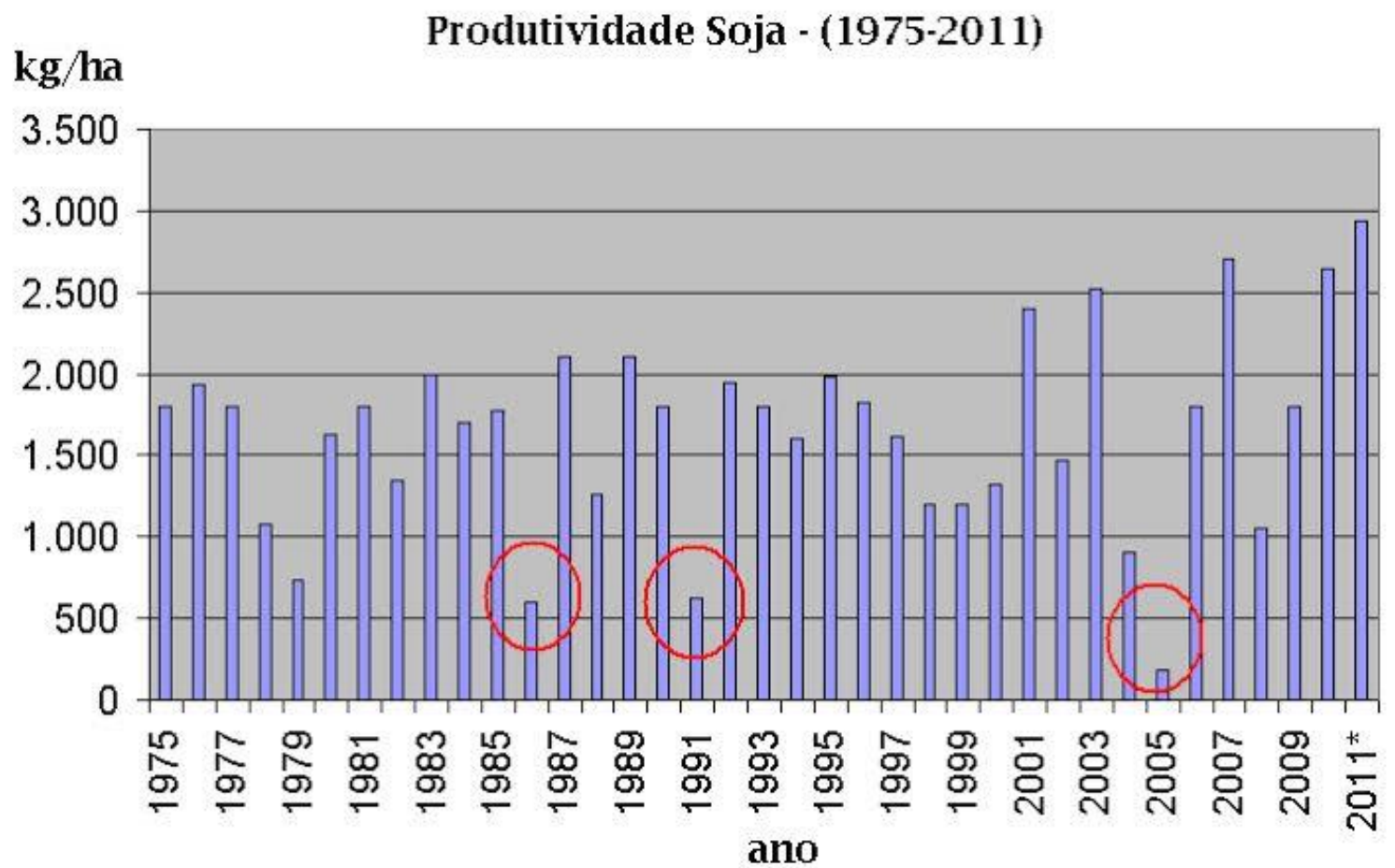

Figura 4.3.8. Gráfico evidenciando o rendimento kg/ha da soja entre 1975 e 2011 em Santa Rosa.

Fonte: IBGE/RS- 2012 
Os efeitos do El Nino e da La Nina não são tão pronunciados na cultura do milho na Região Noroeste do RS em função de o plantio dessa oleaginosa ser realizado em agosto (Figura 4.3.9), com vistas a escapar do período crítico de déficit hídrico, de janeiro a março, e dar oportunidade a uma segunda safra, a denominada "safrinha". Dessa forma, no período reprodutivo e de maior necessidade hídrica, de outubro a novembro, ainda ocorrem chuvas regulares e em volumes significativos.

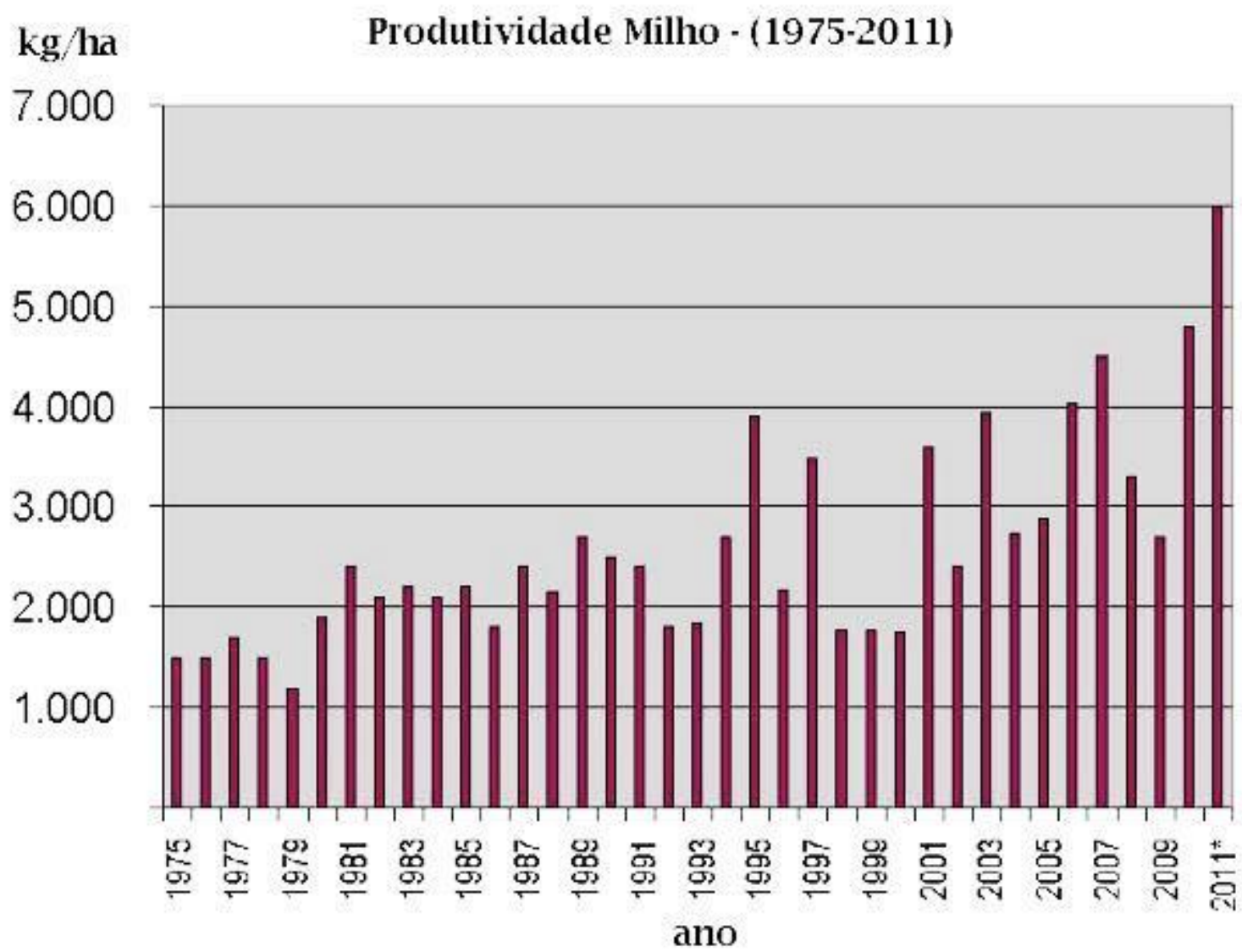

Figura 4.3.9. Gráfico evidenciando o rendimento kg/ha de milho entre 1975 e 2011, em Santa Rosa.

Fonte: IBGE-RS, 2012.

A produtividade do trigo (Figura 4.3.10), por este ser uma cultura de inverno, não tem correlação com os períodos de veranico levantados, já que a cultura é implantada em maio e junho e colhida em outubro, no Noroeste do RS. O principal fator relacionado com a produtividade do trigo é o nível tecnológico adotado pelo produtor, e os fatores limitantes da produção são a ocorrência de geadas e chuvas fortes na fase de espigamento do cereal. 
Para as semeaduras de maio normalmente se constata que os riscos de geada na floração são elevados (maiores que 20\%) em duas regiões: o Nordeste do Estado, especialmente nos Campos de cima da Serra e no Planalto Médio, e no Sudeste, especialmente na Campanha e nas regiões de fronteira com o Uruguai e a Argentina. (CUNHA et al., 1999). Porém para os riscos de chuvas, observa-se que a probabilidade de haver problemas na época de colheita são maiores na metade norte do Estado porque chove mais nessa região do Rio Grande do Sul. Quando na primavera, passam a atuar outros sistemas atmosféricos como os complexos convectivos de mesoescala - CCM, que se formam no Paraguai e se deslocam sistematicamente para o Sul, atingindo a Região da Fronteira Noroeste do RS (BERLATO,1992)

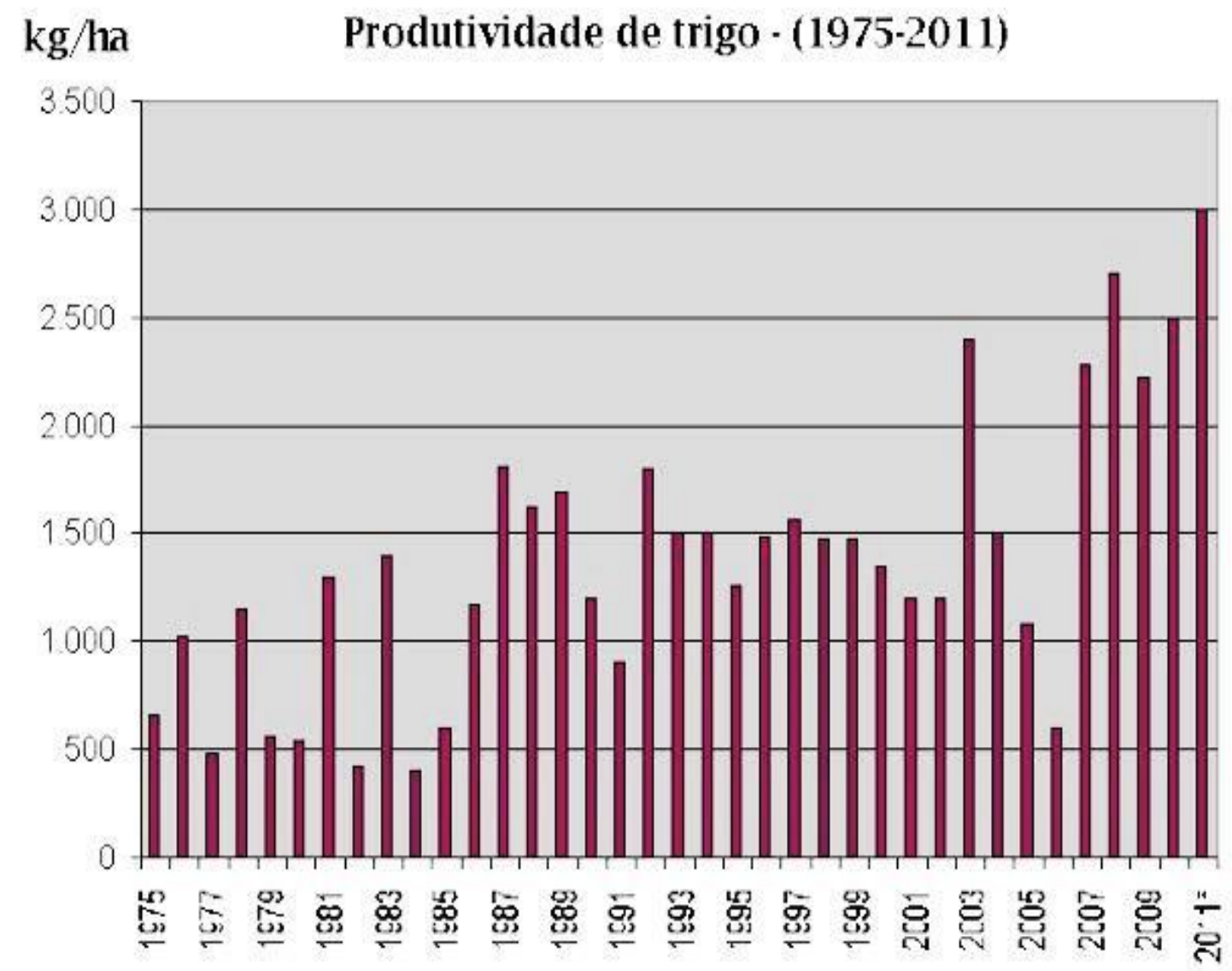

Figura 4.3.10. Gráfico evidenciando o rendimento kg/ha de trigo entre 1975 e 2012, em Santa Rosa.

Fonte: IBGE-RS, 2012. 


\subsection{ORGANIZAÇÃO COOPERATIVA}

A partir da década de 1970, o Brasil consolida a modernização da agricultura em diversas regiões e amplia o processo de industrialização dos produtos gerados pela agropecuária com o desenvolvimento da indústria frigorífica, leiteira, de máquinas e equipamentos de suporte agrícola, o que permitiu um reposicionamento da Fronteira Noroeste do Rio Grande do Sul em relação ao mercado estadual e nacional, bem como internacional com países integrantes do MERCOSUL e outros da Ásia, da África e a Rússia (BUTTEMBENDER et al. 2010, p. 20).

$\mathrm{Na}$ mesma época, no universo agrícola da Fronteira Noroeste, manifestavam-se algumas dificuldades por parte dos produtores quanto ao gerenciamento da produção especialmente na questão da comercialização dos produtos, que de certo modo foram enfrentadas pela ação das cooperativas. As cooperativas agrícolas são os estabelecimentos que mais recebem a produção na região e depois, as indústrias, as empresas integradoras e os intermediários (MORLIN et al., 2012).

Dentre as dificuldades enfrentadas na comercialização, vale destacar: a validade dos produtos de origem agrícola; a distância dos grandes centros consumidores; o baixo nível de renda associado à fragilidade econômica entre as diversas camadas da população; a deficiência de programas, projetos ou ações de estímulo à venda dos produtos, juntamente com serviços de agroturismo, concurso de degustações, festas e, por vezes, a inexistência ou o difícil acesso aos canais de comercialização formais (MORLIN et al., 2012).

É pela existência destas dificuldades que a ação das cooperativas, das indústrias, das empresas integradoras e dos intermediários na comercialização agrícola ganha importância. Elas desempenham diversas funções e realizam variadas transformações nos produtos, no sentido de que são criadas propriedades ou qualidades nos bens que os tornam aptos a satisfazer às necessidades humanas. Estes agentes, quando participam dos canais de comercialização, ficam responsáveis pelo beneficiamento, embalagem, transporte e armazenamento mediante uma remuneração que corresponde à margem de comercialização (HOFFMANN et al., 1987, apud MORLIN et al., 2012). O autor ainda esclarece que se, por um lado, eles se apropriam de uma parcela considerável do valor agregado, por vezes até de forma excessiva, por outro, eles são responsáveis por garantir uma estabilidade mínima necessária à produção e circulação dos produtos. 
Assim como no caso do milho e do trigo, o papel das cooperativas na comercialização agrícola da soja no RS é marcante, estando os princípios da cooperação presentes em várias das etapas de constituição de sua sociedade: o período das reduções jesuíticas; o modelo caboclo; o estabelecimento dos colonos advindos de outras colônias rio-grandenses; o molde cooperativo empresarial, funcionando como subterfúgio às crises econômicas que se seguiram aos anos de 1960 e 1980, até o período atual (BUTTEMBENDER et al. 2010, p. 10-24).

Atualmente, os produtores de grãos na região de estudo entregam a maior parte da produção às diversas cooperativas agrícolas. Assim como na maior parte do território nacional, o cooperativismo agrícola ainda é o de maior expressividade econômica no universo de mais de dez ramos cooperativos.

Dentre outras cooperativas agrícolas da Fronteira Noroeste e adjacências, tomase como exemplo a Cooperativa Mista São Luiz, ou Coopermil, hoje atuante em seis municípios da Noroeste do Estado: Santa Rosa, Tuparendi, Santo Cristo, Novo Machado, Giruá e Candido Godói (Figura 4.4.1). Fundada em 27 de agosto de 1955, na localidade de Cinquentenário - então distrito de Santa Rosa e hoje integrante do município de Tuparendi - contava inicialmente com a participação de 47 associados ligados à agricultura e hoje ocupa uma das primeiras posições no ranking das empresas com maior retorno fiscal da Região.

A empresa atua em diversos ramos de negócios, como na área de grãos: soja, trigo, milho, girassol e outros; na área animal, dispõe de uma área produtora de leitões, que são repassados aos associados para a engorda e posterior venda à cooperativa; adquirindo e comercializando leite na área de varejo, com rede de supermercados, postos de combustíveis, lojas de insumos agrícolas, ferragens e medicamentos veterinários; e na produção de sementes de soja, trigo e aveia. 


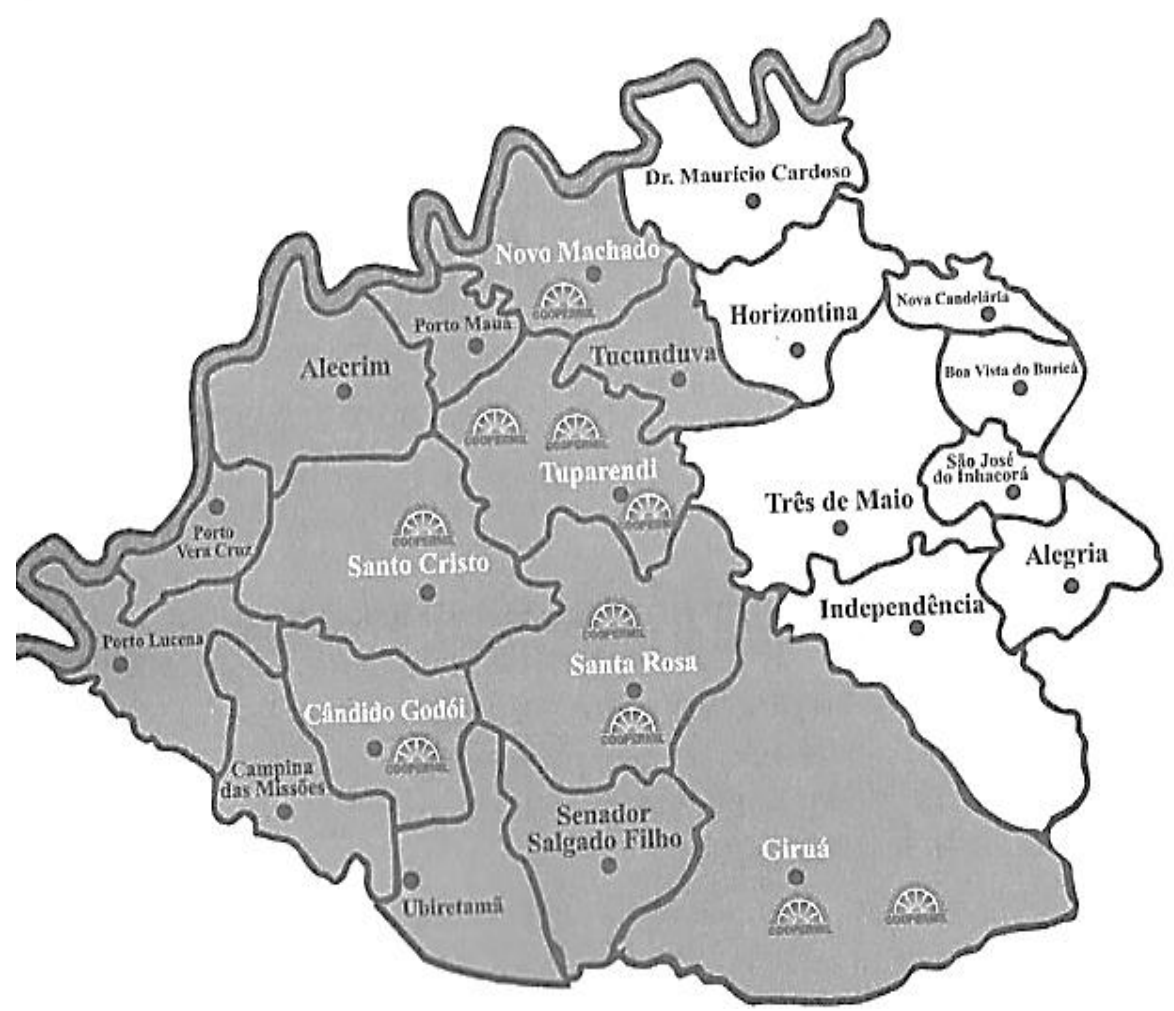

Figura 4.4.1. Identificação, em tom cinza, da Coopermil em seis municípios da então região da "Grande Santa Rosa".

Fonte: Laboratório de Geoproc Unijuí 2008, apud Seescop/RS, 2010.

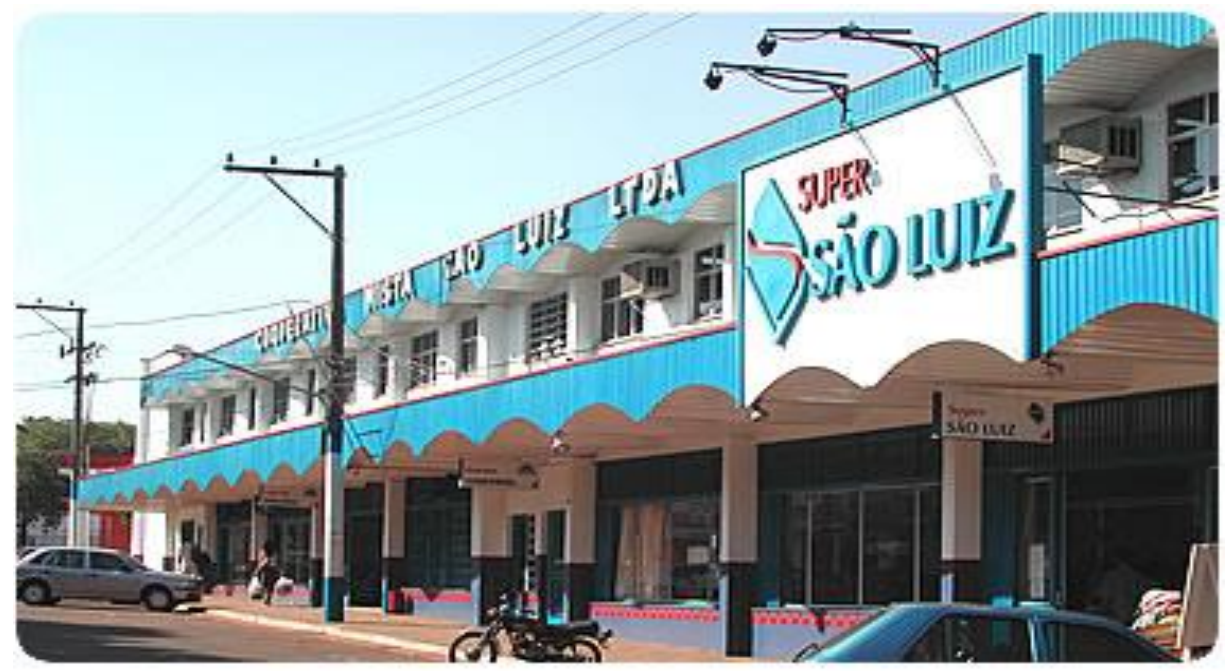

Figura 4.4.2. Sede administrativa da Cooperativa Mista São Luiz Ltda em Santa Rosa.

Fonte: http://www.coopermil.com.

Em 1987, a Cooperativa mudou a sede administrativa de sua matriz para Santa Rosa (Figura 4.4.2), ampliando com isso seu espaço operacional e seu quadro social, 
favorecida de uma rede bancária, da estrada de ferro e do entroncamento rodoviário, que lhe facilitou a expansão e o trabalho no domínio regional.

A Cooperativa tem capacidade de armazenagem estática de 2.030 .000 sacas e possui uma fábrica de rações com capacidade de produção mensal de 2.000 toneladas; participa, em cooperativa de segundo grau com a Cooperativa Central Agroindustrial Noroeste, na industrialização de farinha de trigo com capacidade instalada do moinho de 300.000 sacos/trigo/ano; na industrialização de farinha de milho com capacidade instalada de 50.000 sacos/milho/ano, na Cerealista de produtos agrícolas e na industrialização de óleo de soja e da Cooperativa Central Gaúcha Ltda - CCGL.

O mapa da Figura 4.4.3 mostra a distribuição das sedes de cooperativas agropecuárias no RS, percebe-se que as cooperativas agropecuárias estão distribuídas ao longo de todo estado gaúcho, concentradas mais na porção norte/noroeste e sudeste e pouco menos na metade sul do Estado. Os triângulos em lilás correspondem a 217 cooperativas gaúchas de diferenciados portes existentes entre os diversos municípios gaúchos. Logo, os triângulos de cor laranja correspondem a 11 sedes de entidades cooperativas de produção agropecuárias, estas, concentradas mais significativamente na Região Metropolitana de Porto Alegre e espalhadas pela região da Serra, Norte e Noroeste do RS. 


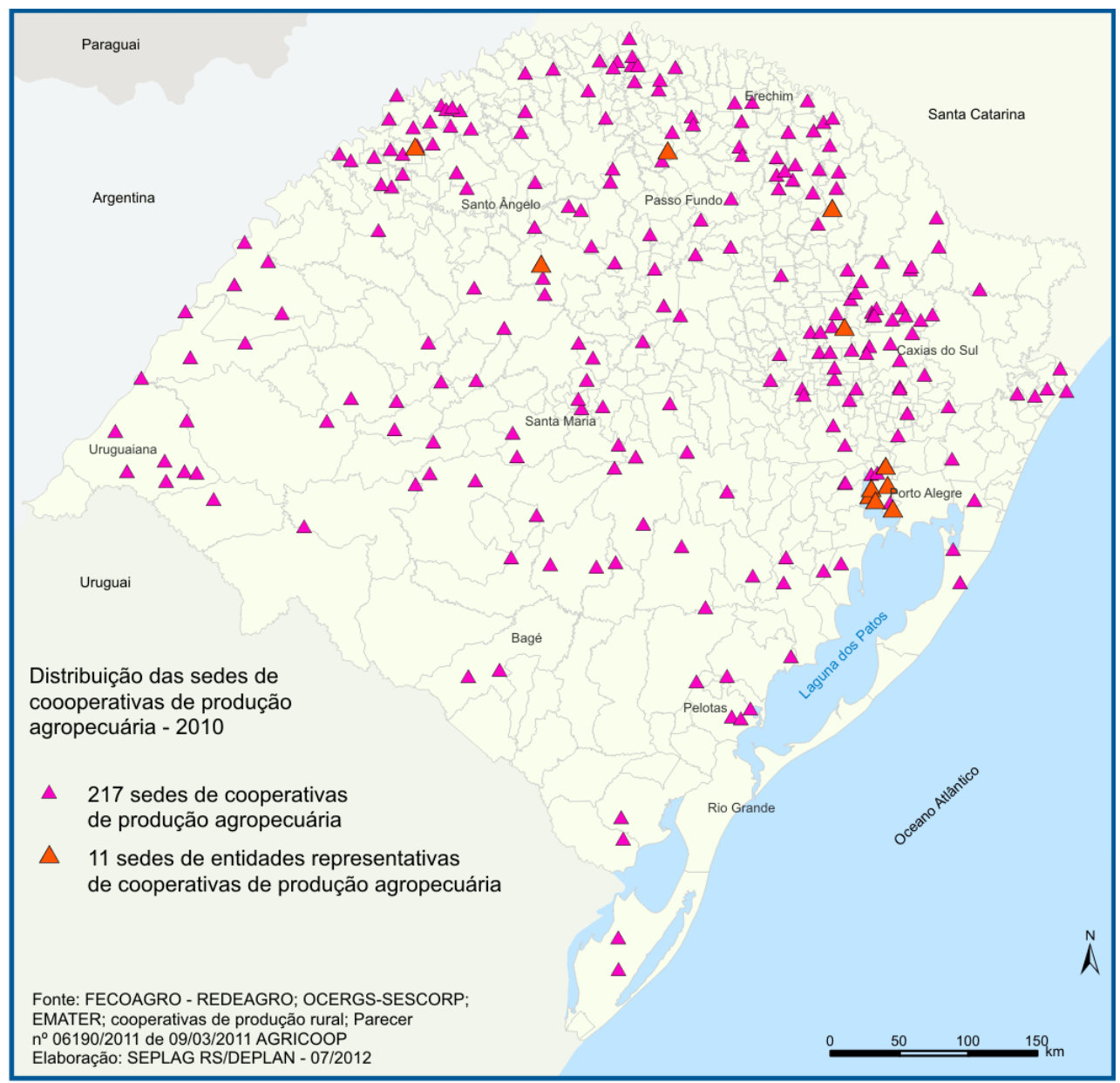

Figura 4.4.3. Distribuição das sedes de cooperativas agrícolas no RS, em 2010. Fonte: SEPLAG RS/DEPLAN, 2014

\subsection{EMPRESAS INDUSTRIAIS}

Por ter calcado o seu desenvolvimento essencialmente na produção agrícola e pecuária as quais induziram as primeiras iniciativas de industrialização em Santa Rosa, o município soube se apropriar das benesses proporcionadas pela expansão da cultura da soja, da produção suína e do gado leiteiro até chegar ao desenvolvimento de um reconhecido parque fabril alimentar e metalmecânico.

Grosso modo, a indústria alimentar local se concentra em três categorias de produtos: laticínios, óleo e farelo de soja e frigoríficos. Associada à produção alimentar, está a produção de implementos e insumos agrícolas e máquinas automotrizes, que representam o potencial dinâmico do Corede Fronteira Noroeste. 
$\mathrm{Na}$ fase inicial, ao lado da economia doméstica embasada na agricultura de subsistência surgem, na década de 1920, pequenas indústrias para aproveitamento da riqueza florestal. Inicialmente destinada à construção de casas e instalações para os novos moradores que viviam nas colônias e, aos poucos, o trabalho com a madeira vai ganhando importância maior, possibilitando o surgimento de várias serrarias bem próximas aos povoados e sedes dos núcleos coloniais. A madeira bruta ou beneficiada era também destinada a outras localidades do Rio Grande do Sul e de países vizinhos. Grandes balsas de madeira de lei desciam o rio Uruguai com destino a San Tomé, (Argentina), Itaqui e Uruguaiana (Christensen, 2004, p.131). No período, as indústrias derivadas da agricultura tiveram também um desenvolvimento acentuado, como os moinhos de farinha de trigo e mandioca, as fábricas de cerveja, gasosa, de vinho e aguardente.

É conveniente salientar que a indústria mais expressiva do primeiro período da economia de Santa Rosa foi a indústria ervateira. Nos primeiros trinta anos do século passado existiam os soques de erva-mate e os engenhos de madeiras dos caboclos que ali viviam. Segundo Rotta (1999, p. 53-54), a exploração de ervais nativos, iniciada no período jesuítico (1682-1756) e retomada após a consolidação do domínio português, principalmente a partir de 1830, proporcionou o desenvolvimento do extrativismo vegetal e o primeiro processo de industrialização da erva-mate antes mesmo da colonização. Posteriormente, a produção de erva-mate continuou a crescer, pois

a industrialização da erva-mate se intensificou com a colonização. A existência, em 1927, de onze indústrias ervateiras na região, com produção em torno de $100.000 \mathrm{~kg}$ anuais, a maioria destinada aos mercados platinos, demonstra a importância da erva-mate na economia regional no inicio deste século. Num período próximo à emancipação, em 1931, chegou a haver uma cooperativa que regulava a produção do mate, a "Cooperativa do Mate Missioneiro" (SCHALLEMBERGER; HARTMANN, 1981, p.123, apud ROTTA, 1999, p. 54).

Mais tarde, com a operação de equipamentos mecânicos modernos, a partir da década de 1980, ocorrem mudanças no processo produtivo, como secagem, moagem e ensacamento da erva. É destacada a Indústria Ervateira Vier, localizada na BR-472, em Guia Lopes, distante a $4 \mathrm{~km}$ do perímetro urbano de Santa Rosa. A Empresa modernizou suas instalações e seu processo de produção para enfrentar a concorrência 
de outras marcas presentes no mercado, passando a qualificar os funcionários e a incentivar o cultivo da matéria-prima em parceria com produtores rurais.

A empresa dispunha, ainda nos anos finais da década de 1990, mais de 100 funcionários distribuídos nos setores de produção. Estruturada e equipada, tem um processo produtivo diferenciado até chegar às diversas qualidades de erva-mate. Dispõe de um mercado forte na Fronteira Noroeste e na Área Metropolitana, mas sua produção cobre todo o Brasil, devido, principalmente, à emigração dos gaúchos desde os anos de 1960 às diversas regiões brasileiras, bem como aos países do Mercosul.

Com $20 \%$ da matéria-prima provindo da região e $80 \%$, de outras, a Indústria Ervateira Vier foi e ainda permanece líder na região na fabricação de erva-mate, sendo fabricada também em Santa Catarina e no Paraná. A empresa configura-se como uma das principais em arrecadação e retorno de ICMS para o município.

A década de 1950 pode ser entendida como um período de uma reorganização no modelo socioeconômico regional (ROTTA, 1999, p. 71). Isso porque o modelo que vinha sendo construído desde a colonização entra em declínio. Visto por outro lado, marcou o auge da crise à medida que o comércio e a indústria tradicionais já passavam por um processo de redefinição ainda nos anos de 1940. O autor destaca que de certa forma o "ciclo do suíno", como ficou conhecida na região a década de 1950, coincidiu com o auge de um modelo e o início de seu processo de redefinição.

O esgotamento das terras novas, áreas de mato que eram abertas anualmente, levou a uma intensificação do uso daquelas áreas próprias para agricultura existentes na propriedade na década de 1950, em Santa Rosa. A pouca rotatividade dos produtos cultivados, dada a necessidade de alimentar os suínos e produzir o que tinha demanda no mercado e à ausência de técnicas de preservação e correção do solo ocasionaram a queda da produtividade agrícola, levando a um aumento do custo de produção do suíno e à perda da competitividade em relação a outras regiões do estado (ROTTA, 1999, p. 71).

O suíno era a base que servia de suporte para a ativação da economia regional e uma crise na sua produção geraria consequências em cadeia que acabariam atingindo todos os setores da economia e da sociedade regional. Em decorrência da queda da produtividade agrícola da cultura do milho, haveria repercussão em toda a cadeia produtiva. 
A suinocultura sempre foi abrangente na Região Sul como um todo. Primeiramente, a atividade esteve voltada para o consumo próprio e exportação de banha e, mais tarde, devido aos novos hábitos alimentares e o advento da soja, passouse a dar maior importância ao suíno carne enquanto a banha de porco foi substituída pelo óleo de soja (BRUM et al., 2008). O Brasil, no entanto, passou a se destacar como forte produtor, consumidor e exportador de carne suína umas décadas posteriores. Antes disso, a produção brasileira havia sofrido um enorme impacto negativo com a eclosão da peste suína africana, que levou ao abate de rebanhos inteiros em quase todas as regiões produtoras. Tal situação cessou a produção diminuindo o consumo local.

Dentre as diversas atividades que possibilitavam a obtenção de renda para a comunidade regional destacava-se a produção pecuária. De olho no crescimento do segmento pecuário suíno em determinadas áreas do RS, por volta da década de 1950 começam a ser postas em prática algumas iniciativas locais para trazer à região esse tipo de investimento.

A suinocultura se transformou na principal fonte de renda para a agricultura familiar e uma forma de agregar valor aos produtos agrícolas. A demanda existente no mercado garantia a compra do produto quer pelos comerciantes do interior, quer pelos representantes dos vários frigoríficos do RS que mantinham compradores autorizados em Santa Rosa, caso dos frigoríficos Rizzo, Swift, Wilsons e Serrana (ROTTA, 1999, p. $59)$.

A expressiva produção de suínos começou a chamar atenção de frigoríficos de outras partes do RS que pensavam em instalar abatedouros na região. Dadas as distâncias para os deslocamentos dos suínos para as praças de industrialização fez-se pertinente a criação de um frigorífico local. E assim, em abril de 1956, cria-se o Frigorífico Santa-rosense.

A empresa foi fundada mediante uma cotização entre alguns empresários e os próprios produtores. $\mathrm{O}$ gerenciamento da indústria de beneficiamento do suíno era feito exclusivamente pelos empresários que no decorrer dos anos absorveram as quotas dos produtores. Tempos depois, em abril de 1986, altera-se a denominação social para Prenda S.A.

Nos anos iniciais, absorvia-se todo e qualquer tipo de suíno, uma vez que a banha tinha mercado garantido. Por esse motivo eram recolhidos animais dos pequenos produtores e daqueles que se dedicavam a produzir em larga escala. Havia sazonalidade de produção sendo que toda a criação era comprada. Como o mercado consumidor da 
banha vinha sendo suplantado pouco a pouco pelo consumo de óleo vegetal, a exigência passa a ser canalizada para a produção da carne. A partir desse momento dava-se início a uma melhor especialização da suinocultura. Para tanto, importaram-se de outras regiões matrizes e técnicas de produção suína para extração da carne.

Em 1957, a empresa abatia e processava cerca de 200 suínos por dia. Os maiores produtores eram os municípios de Santo Cristo, Cerro Largo, Santa Rosa, Tucunduva e Tuparendi. Naquela época, havia o apoio da política econômica vigente que permitia recursos financeiros junto aos bancos oficiais, além da confiança dos credores e fornecedores. Na fase inicial, o Frigorífico Santa-rosense tinha apenas 32 empregados e, com o passar dos tempos, entre as décadas de 1980 e 1990, a média estava em cerca de 1.200 trabalhadores, somente na empresa matriz. Como a empresa contava com mais filiais pelo Estado e pontos de distribuição e produção, somavam-se ainda outros 400 trabalhadores.

A Prenda S.A. produzia mais de 100 produtos, como a banha refinada, o torresmo, o bacon ou a linha de embutidos, como presuntos, fiambres, mortadelas, salsichas, linguiças, salame tipo italiano, salame hamburguês, copa defumada/curada e a linha de fatiados, além de carcaças, cortes congelados salgados e defumados. As fases de maior produção dos diversos artigos da empresa deram-se durante o período de sua fundação e, num segundo momento, nas décadas de 1980 e 1990.

O pessoal da empresa revelou que "o mercado consumidor local é considerado limitado, devido à presença de vários microfrigoríficos e produtores artesanais no circuito regional de embutidos de carne suína, principalmente, e de conservas". Sua produção chegava até centros urbanos como São Paulo, Rio de Janeiro e Curitiba e também se abriu mercado nos países do Mercosul.

Cabe salientar que toda a matéria-prima de abate servia à industrialização. A Prenda S.A diversificava sua produção, fabricando de derivados suínos a sabão. É notável também a fabricação de rações e concentrados, equipamentos de suinocultura; e no reflorestamento a Empresa dava assistência técnica aos produtores nas granjas de apoio no perímetro regional. Grande parte das máquinas e equipamentos utilizados nos diversos setores da indústria provinha do mercado nacional, bem como de alguns países da Europa e dos EUA.

Após a venda do Frigorífico Prenda S. A. para outros grupos estrangeiros a empresa passou a ter outras denominações sociais, até chegar ao atual Alibem. Com a Alibem, fundada em 2000 na cidade de Porto Alegre, as atividades de criação e abate de 
suínos tiveram início em 2001, com a aquisição de sua primeira estrutura composta por frigorífico, granja e fábrica de rações, na cidade de Santo Ângelo, integrante do Corede Missões.

Em 2004, a Alibem assumiu o complexo industrial localizado na cidade de Santa Rosa (Figuras 4.5.1 e 4.5.2), tradicional polo produtor da suinocultura gaúcha, composto por uma fábrica de rações, três granjas e uma unidade industrial com grande capacidade de abate de suínos e produção de industrializados. Em 2006, adquiriu o Frigorífico Agra, estendendo seus negócios ao Centro-Oeste do Brasil, no Estado do Mato Grosso. Ainda neste ano concretizou a compra de outro frigorífico, em Jacarezinho, no Estado do Paraná.

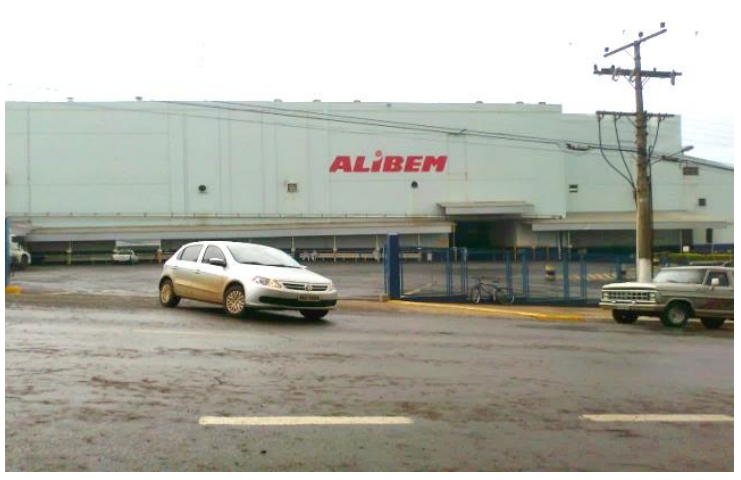

Figura 4.5.1. Alibem Santa Rosa

Fonte: $\mathrm{O}$ autor.

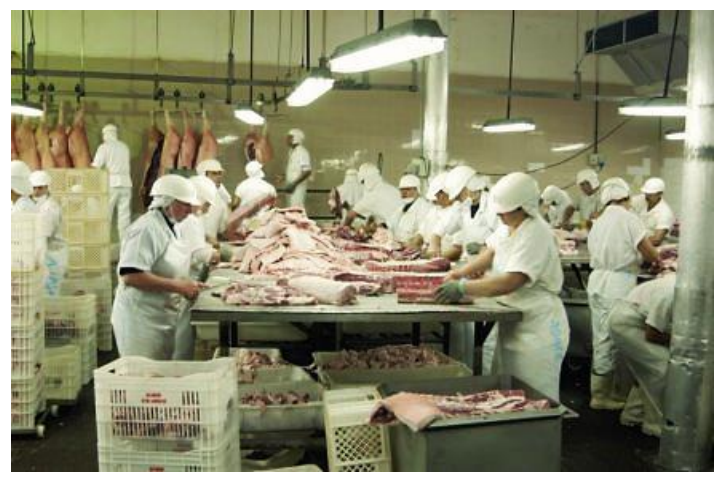

Figura 4.5.2. Alibem Santa Rosa

Fonte: http://www.alibem.com.br

A marca da Empresa hoje está presente nas principais regiões do Brasil, sendo exportada para mais de 40 países, entre Hong Kong e Venezuela. Até 15/06/2011, a Rússia era o melhor e maior mercado. O Frigorífico atualmente conta com 3.000 trabalhadores na região, destes, 1.700 estão na planta industrial de Santa Rosa. Cerca de 300 deles vêm diariamente de outros municípios como Alecrim, Campina das Missões e Tucunduva. É a maior geradora de ICMS no município (SEFAZ, 2014). Além disso, tem aproximadamente 900 parceiros na criação de suínos, com destaque para o município de Nova Candelária. A Empresa comercializa atualmente desde produtos industrializados, como cozidos, embutidos, defumados e salgados, até produtos in natura, como carcaça, filé, miúdos, paleta, pernil, gordura, pele etc.

A crescente urbanização, provocada pela aceleração da economia a partir da década de 1960, sobretudo nas Regiões Sudeste e Sul do Brasil, permitiu a aglutinação do espaço urbano e rural. É o caso de muitas indústrias estabelecidas na década de 1950 
que hoje sofrem com o problema de inadequações físicas por estarem inconvenientemente instaladas na altura do perímetro urbano de seus municípios.

Quando fundado, o atual Frigorífico Alibem localizava-se em área denominada rural, fora do perímetro urbano, mas com o passar dos anos a especulação imobiliária possibilitou a instalação de muitas moradias nos arredores da indústria, o que fez que se tornasse inviável a permanência da empresa frigorífica em seu endereço. Os maiores problemas são a geração e a emissão de gases nocivos, percebidos nas áreas residenciais, principalmente em dias de ventos e de alta umidade do ar, bem como os efluentes líquidos gerados e despejados nos cursos de água da cidade.

Apesar dos percalços sentidos durante a trajetória de produtores de rebanho suíno na região, justificados pelo descontentamento em relação aos custos dos insumos e valores pagos pela produção, houve um incremento considerável no número de suínos entre os anos de 1980 e pós-2000, liderado pelos Estados do Sul. De um rebanho total estimado em 33,6 milhões de cabeças em 2006 (que em 1997 era de 29,6 milhões), a Região Sul contribuiu com 14,5 milhões de animais, isto é, 43,2\% do total, sendo 5,8 milhões em SC, 4,5 milhões no Paraná e 4,2 milhões de cabeças no RS (BRUM et al., 2008, p. 160).

Os anos de 1980 e 1990 se caracterizaram por uma intensa mudança na estrutura da economia do Brasil repercutindo também na modificação da estrutura patrimonial do parque industrial nacional, sobretudo pela intensificação dos fluxos de capitais estrangeiros. Nesse sentido também se estabeleceram novas formas de atuação dos agentes integrantes do complexo agroindustrial laticínio, especialmente nas mudanças verificadas no âmbito da concorrência que deflagraram uma intensa mudança patrimonial na estrutura dessa indústria.

No período anterior às transformações estruturais da economia do Brasil, as empresas integrantes do complexo industrial laticínio se dividiam basicamente em empresas multinacionais, correspondentes aos grandes grupos privados controlados por capital de origem externa, com abrangência nacional, geralmente possuindo uma marca consolidada e os grupos nacionais, tipificados por uma atuação mais regionalizada, apresentando especialização em alguns produtos; as cooperativas, dentre as quais as singulares ou de primeiro grau, voltadas, principalmente, para o consumo local em mercados regionais, e as cooperativas centrais ou de segundo grau, que são constituídas por um grupo de cooperativas singulares; e por fim, os pequenos laticínios, de alcance regional, atuando muitas vezes de forma clandestina, sem inspeção sanitária (JANK et 
al., 1999, apud CARVALHO, 2005). Além das mudanças de caráter patrimonial, outras modificações trouxeram impactos, de maior ou menor intensidade, para a indústria de laticínios.

Partindo-se de alterações mais gerais, mas que repercutiram diretamente sobre e indústria de laticínios tem-se a abertura do mercado nacional, que propiciou um fluxo intenso de capitais externos, capitais estes que se destinaram a elevar os investimentos diretos externos realizados na economia brasileira. No caso da indústria do leite, esses recursos foram os responsáveis diretos pela onda de fusões e aquisições que assolou esse setor (CARVALHO, 2005).

A abertura da economia brasileira, seja pela facilitação da entrada de produtos industrializados ou pelo aumento do fluxo de investimento direto externo, induziu a uma mudança de postura das empresas estabelecidas no Brasil, que após um período de acomodação tiveram que se adaptar às novas condições de mercado. A busca de vantagens competitivas fez com que as empresas buscassem um aumento de escala, possibilitando assim a realização de investimentos de maior capital. Esse processo levou a constituição de grandes firmas industriais.

A partir dos anos 1980, o setor laticínio passou por diversas transformações. O ponto de partida dessas mudanças e uma das mais significativas que afetou o setor leiteiro foi a suspensão do controle e do tabelamento dos preços, que vigorou de 1945 a 1991. O término dessa prática por parte do governo agiu como um incentivo à entrada de novas empresas que passaram a atuar com maiores graus de liberdade, pois o tabelamento dos preços do leite e de seus derivados agia como um desestímulo à criação de novos produtos, com maior valor agregado, visto que o teto já havia sido determinado pelo governo. Assim, com a liberalização dos preços, pela ótica da produção de matéria-prima, fez-se presente a possibilidade das empresas adotarem pagamentos diferenciados, de acordo com as características do produto. Essa liberalização dos preços deve ser vista como integrante de um processo mais amplo de desregulamentação dos mercados (CARVALHO, 2005).

Em caráter regional, a bovinocultura leiteira desponta na geração de renda para a região de Santa Rosa, uma vez que as características de ocupação dessa região, ainda no final do século XIX e início do século XX por descendentes europeus não ibéricos, com base na pequena propriedade familiar, criaram uma tradição agropecuária assentada na produção de suínos e bovinos de leite. Tanto o rebanho suíno como o leiteiro se constituem como elementos centrais de geração de renda na região pela diversificação. 
A produção gaúcha de leite está dividida em diferentes bacias leiteiras, sendo que uma delas abrange boa parte de municípios da Mesorregião Noroeste do RS e suas subdivisões microrregionais. É típica de pequenas propriedades, pela possibilidade de efetivação em pequenos espaços físicos, tendo se encaixado perfeitamente no perfil fundiário regional. Inicialmente produzia o leite de maneira rudimentar e hoje, de forma modernizada e eficiente, visando ao mercado, inclusive de exportação. A produção regional teve início em meados dos anos de 1950 e se consolidou pouco a pouco.

Segundo observações da Organização Mundial da Saúde:

efetivamente, o consumo brasileiro de leite ainda hoje está longe do ideal. (...) cada pessoa deveria consumir anualmente, no mínimo, 175 litros. No Brasil o consumo per capita beira os 130 litros, fato que indica uma defasagem de 45 litros per capita. Na prática o consumo nacional de leite igualmente sofre com o problema de má distribuição de renda no País (BRUM et al. 2008, p. 157).

A empresa que correspondeu inicialmente ao beneficiamento da produção de leite em Santa Rosa era a Laticínios Mayer, fundada no ano de 1949, cujo capital inicial era fruto de economias particulares da família Mayer. Primeiramente, fabricava queijo e manteiga, logo passou a produzir requeijão e doce de leite.

As áreas de coleta de "creme", assim denominada na época, eram determinadas em comum acordo. Esse esquema organizacional se deu logo quando iniciou a coleta da matéria-prima, em respeito ao trabalho de fomento à produção que cada uma das indústrias mantinha com o produtor. A produção leiteira era feita de uma forma desordenada e sua comercialização estava sujeita ao desempenho dos chamados "caminhoneiros compradores", que iam até as propriedades rurais e recolhiam o leite para depois fazer um leilão junto à indústria.

Inicialmente, a produção era destinada à fabricação de manteiga que consistia na transformação da nata comprada dos produtores que desnatavam o leite em suas pequenas propriedades e vendiam o "creme" ao pequeno comerciante que a revendia à indústria. Esse esquema perdurou até o final dos anos de 1950.

Entretanto, no início dos anos de 1960, a partir de então, a empresa passa a industrializar o leite, pasteurizando-o e acondicionando-o em garrafas, que deu impulso à produção de leite na região, pois regularizou sua compra diária e, por consequência, sua produção (ROTTA 1999, p. 84). O método se estende até o ano de 1973 e logo após o produto passa a ser ensacado. Também nesse período produziam-se alguns tipos de 
queijos. A empresa passou a incentivar a melhoria da qualidade genética do gado leiteiro e a regularização da produção, melhorando a renda do produtor. Os produtos da Laticínios Mayer conquistaram o mercado nacional com a marca "Santa Rosa": queijos, leite, nata e manteiga.

A partir de 1976, a Cooperativa Central Gaúcha de Leite Ltda. (CCGL), associada a 13 cooperativas de soja e trigo, comanda o processo produtivo com o objetivo de congregar as cooperativas existentes e diversificar a produção dos associados dessas cooperativas. A baixa produtividade da época concentrou esforços para o produtor no sentido de promover cursos e treinamentos com o comprometimento da CCGL em receber toda a produção junto às cooperativas associadas.

Com a detenção do controle acionário da Laticínios Mayer de Santa Rosa em 1981, a CCGL ampliou a capacidade instalada de produção e comercialização, atingindo também o mercado externo. As marcas Elegê e Santa Rosa continuaram a ser utilizadas pela CCGL em função de sua aceitação positiva no mercado.

A bacia leiteira foi dividida em áreas de acordo com os associados de cada cooperativa singular. A coleta de leite era conduzida à plataforma da CCGL, mas o produtor acertava o recebimento do pagamento com a cooperativa a que pertencia. Os produtores ainda recebiam ajuda técnica da Associação Sulina de Crédito e Assistência Rural - ASCAR

Segundo Rotta et al. (2010, pp. 80-81),

a bovinocultura de leite passou por um processo de modernização nas últimas décadas do século 20 que a capacitou para fornecer matériaprima para as indústrias locais que se instalaram na região e em seu entorno. A região constituiu-se na maior bacia leiteira do Estado do RS, fazendo nascer uma série de empresas que passaram a se dedicar ao fornecimento de insumos para a produção, manejo do rebanho e transformação do leite produzido.

Com a inauguração da primeira unidade industrial no município de Ijuí e a compra de indústrias particulares em dificuldades, foram agregando-se várias unidades industriais, entre elas, as de Passo Fundo, Santa Rosa, Três de Maio, São Lourenço do Sul, Teutônia e Ijuí. Daí então, todo esse investimento culminou no desenvolvimento das bacias leiteiras, modificando as condições econômicas dos agricultores.

Em 1996, o controle acionário da CCGL S.A. passa para o Grupo Avipal alterando sua denominação para Elegê Alimentos S.A., mantendo a antiga marca 
originada em Santa Rosa e atingindo mercados locais, regionais e também outros estados, entre eles São Paulo, Mato Grosso e Bahia. A Elegê Alimentos, em finais de 1997, instalou uma fábrica de queijos finos na região, no município de Três de Maio.

O Estado do RS tradicionalmente participa com cerca de $10 \%$ da produção nacional de leite. Fortes investimentos industriais, visando à transformação deste produto, estão sendo efetivados, dentre eles a instalação da indústria Nestlé, em Palmeiras das Missões; uma indústria, a Embaré, em Sarandi; uma indústria da CCGL em Cruz alta, atestando o retorno do grupo de cooperativas regionais à industrialização do leite; a ampliação da indústria da Elegê Alimentos S.A. (Grupo Avipal) em Ijuí; a ampliação industrial da Cosulati, cooperativa de Pelotas (BRUM et al., 2008, p. 156).

As definições tomadas por ocasião da instalação da fábrica da CCGL (Figuras 4.5.10 e 4.5.11), no município de Cruz Alta (Corede Alto Jacuí), no Noroeste do Estado, podem significar uma nova fase para o setor leiteiro. A fábrica foi inaugurada em outubro de 2008, à margem da rodovia Cruz Alta-Ijuí (RS-342), e custou R\$ 120 milhões, com a criação de 250 empregos diretos e cerca de 1.400 indiretos. Na segunda fase da planta, já projetada, pelo menos $\mathrm{R} \$ 100$ milhões devem ser aplicados para construção de uma queijaria.

Conforme previsão, a unidade da CCGL terá capacidade de industrializar quase 3 milhões de litros de leite diariamente e trabalhará com quase 40 cooperativas que congregam pequenos e médios agricultores, tendo forte presença em todo o Noroeste do RS e mobilizando vários municípios (ROTTA et al. 2010, p. 81).

A realidade comprova que o leite é uma atividade econômica de diversificação importante na região, gerando uma renda significativa e que, para o incremento do desenvolvimento local, merece atenção especial no sentido de carecer maiores e sempre melhores investimentos, desde a infraestrutura junto aos produtores rurais e suas cooperativas, passando pela genética, até o equacionamento mais adequado dos custos de produção, aproveitando-se de que a região é forte produtora de soja, milho, além de outros cereais e pastagens (BRUM et al., 2008, p. 157). 


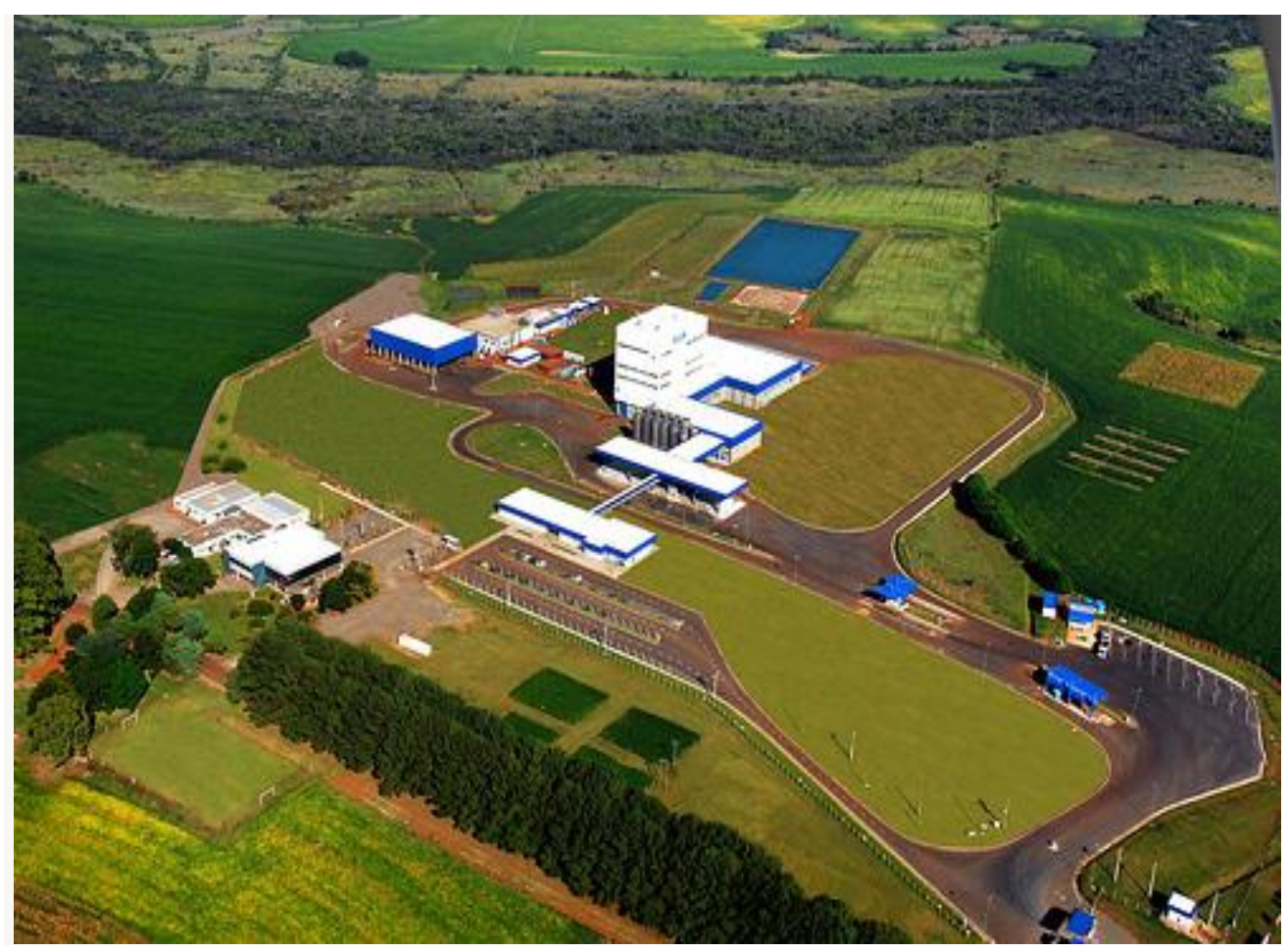

Figura 4.5.3. CCGL Cruz Alta

Fonte: http://Clicrbs.com.br

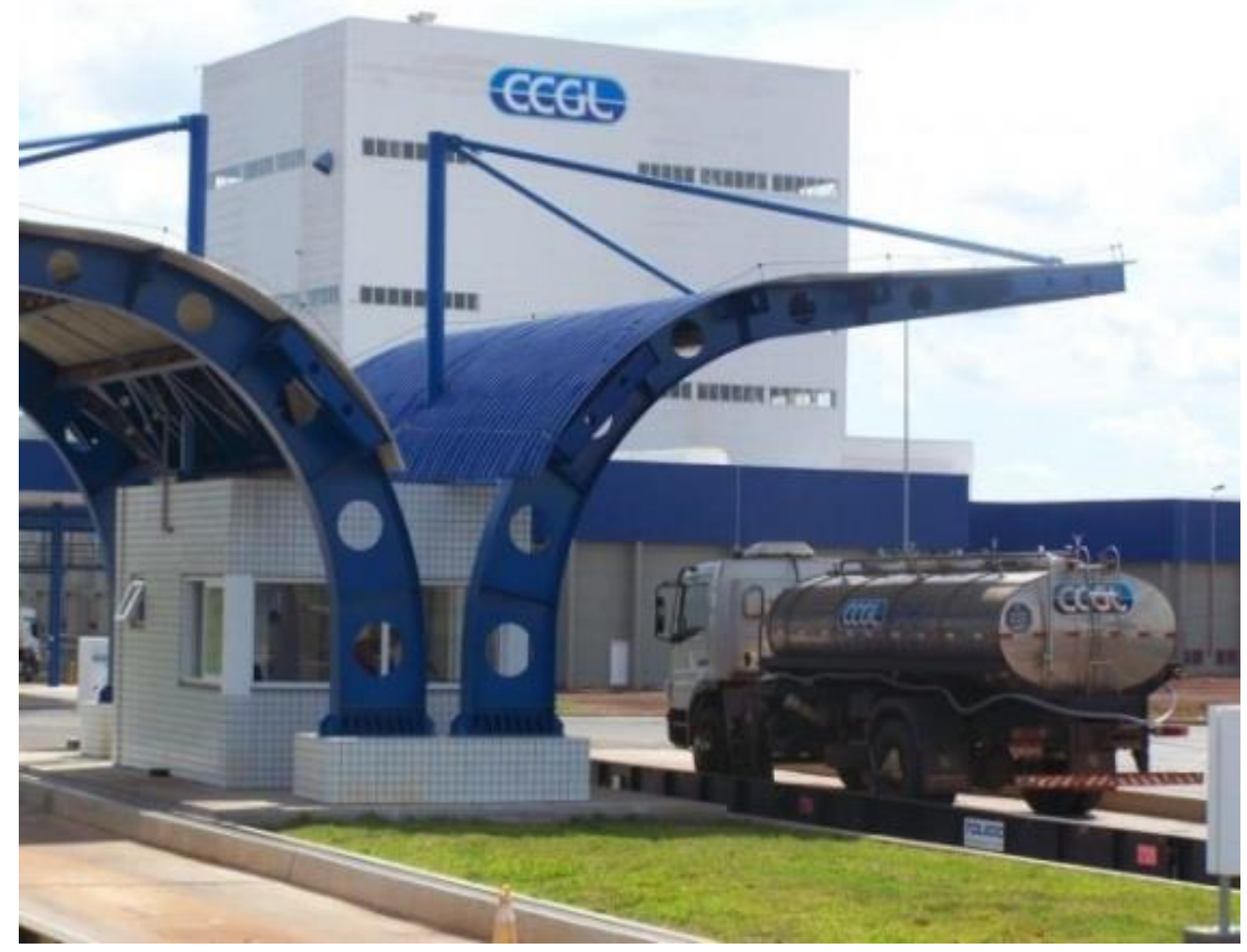

Figura 4.5.4. CCGL Cruz Alta

Fonte: http://Clicrbs.com.br 
Embora o crescimento médio da produção brasileira de leite, quando comparado aos principais produtores mundiais, seja pouco significativo, ainda é importante dentro das condições brasileiras, uma vez que a escala de seus rebanhos produtores é majoritariamente de pequenos e médios agricultores (Figura 4.5.5 e 4.5.6).

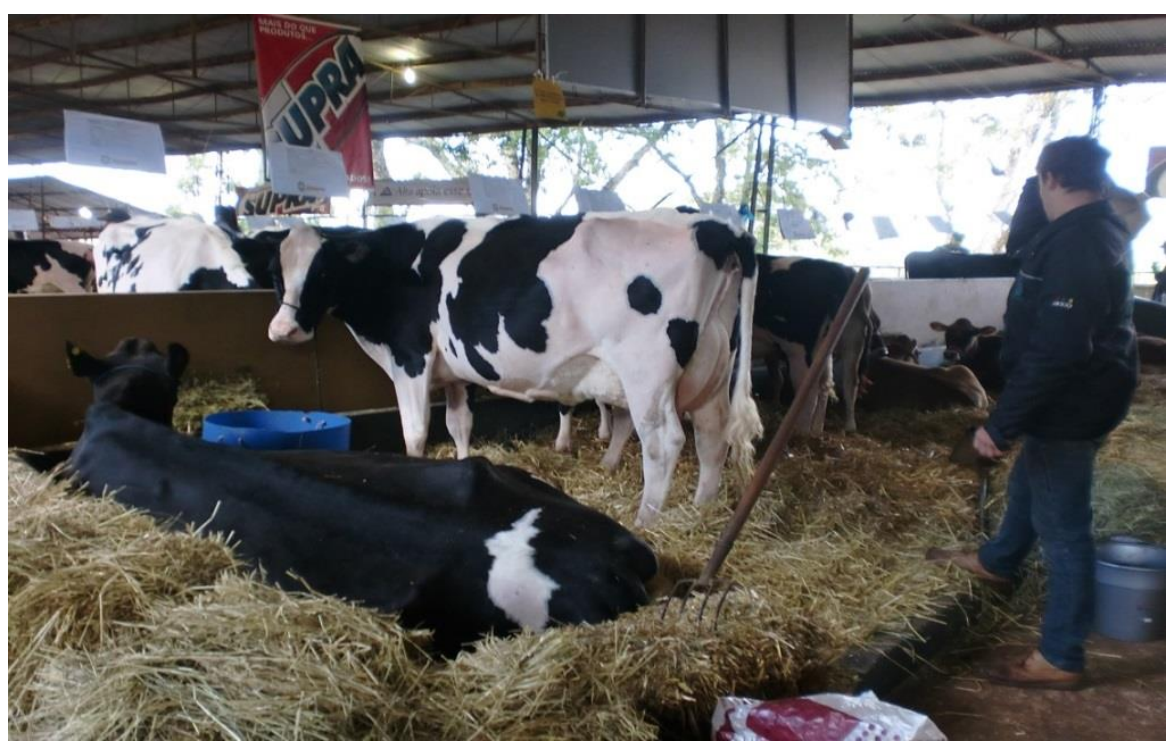

Figura 4.5.5 Exemplares de rebanho leiteiro na Fronteira Noroeste.

Fonte: $\mathrm{O}$ autor

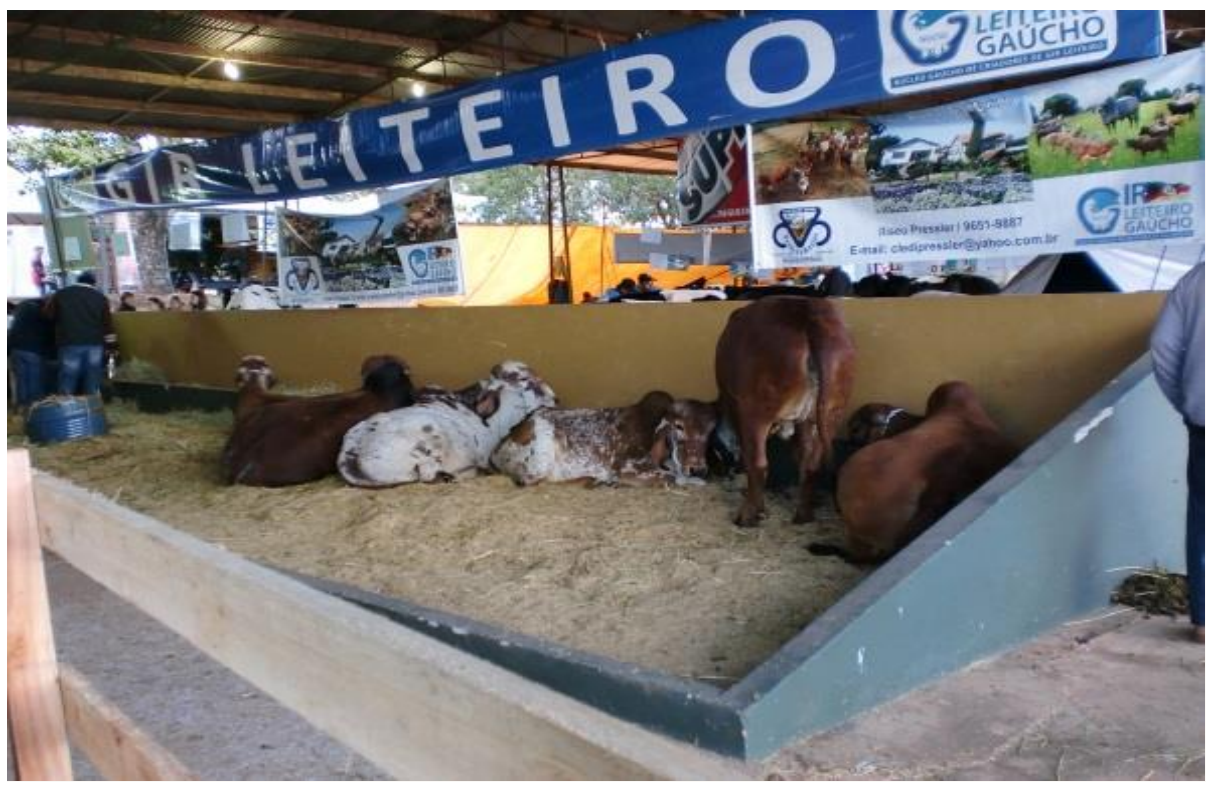

Figura 4.5.6. Exemplares de rebanho leiteiro na Fronteira Noroeste.

Fonte: $\mathrm{O}$ autor 
Informações obtidas no Atlas Econômico do Rio Grande do Sul de 2005 e do IBGE de 2010 indicam que o Rio Grande do Sul, em 2005, no bolo da produção nacional de leite ocupava o terceiro posto, correspondendo a $10,6 \%$ da participação nacional, tendo apresentado uma produção de 2,2 bilhões de litros. Minas Gerais sempre manteve a liderança como primeiro estado produtor, seguido por São Paulo e o Rio Grande do Sul. Historicamente, a produção gaúcha sempre foi suplantada pela mineira, a maior produtora. Por vezes, o RS equilibra a gangorra (Tabela 3.5.1), oscilando na segunda colocação com o Paraná, Goiás e Santa Catarina (IBGE, 2013).

Tabela 4.5.1. Os estados que mais produzem leite no Brasil.

\begin{tabular}{|c|c|c|c|}
\hline Lugar & Estado & $\begin{array}{l}\text { Litros de } \\
\text { leite } \\
\text { produzido }\end{array}$ & $\begin{array}{c}\text { Participação } \\
\text { nacional }\end{array}$ \\
\hline $1^{\circ}$. & Minas Gerais & 8.756 .114 & $27,3 \%$ \\
\hline $2^{\circ}$. & Rio Grande do Sul & $\mid 3.879 .455$ & $12,1 \%$ \\
\hline $3^{\circ}$. & Paraná & 3.819 .187 & $11,9 \%$ \\
\hline $4^{\circ}$. & Goiás & 3.482 .041 & $10,9 \%$ \\
\hline $5^{\circ}$. & Santa Catarina & 2.531 .159 & $7,9 \%$ \\
\hline
\end{tabular}

Fonte: IBGE, 2010.

A produção de leite no Estado do Rio Grande Sul tem na Mesorregião Noroeste a área geográfica líder em produção de leite no ano de 2007 (MORAES, 2010). Os resultados alcançados pelo Noroeste do RS são atribuídos a uma série de fatores, surgidos no decorrer dos anos, dentre os quais a organização da pequena propriedade, que passou a investir na produção de leite, como uma das alternativas de renda. $\mathrm{O}$ interesse da comunidade regional também tem contribuído para esse cenário, à medida que visualizou a produção de leite como uma oportunidade de inserção no mercado.

Entre as regiões com maior produção de leite no Estado do RS estão o Corede Noroeste Colonial com 11,3\%, o Corede Produção com 11\%, o Corede Fronteira Noroeste com 9,4\% e o Corede Serra com 8,1\%. Esses dados confirmam a importância da atividade para a Região Fronteira Noroeste. Conforme dados da Emater de Santa Rosa (2005), existe uma produção de leite média diária na região de sua abrangência de mais de meio milhão de litros de leite, que são destinados à industrialização. (EMATER - RS, 2005 apud EVANGELISTA et al., 2006). 
Ainda na década de 1950, a região da Grande Santa Rosa contava com uma empresa de esmagamento de soja e de extração de óleo vegetal representada pela Indústria Gaúcha de Óleos Vegetais, a Igol, localizada no município de Santa Rosa.

Em 1955, a Igol é adquirida pelos empresários chineses Charles Knug Wei Tse e Sheun Ming Ling que acreditaram num mercado promissor de óleo vegetal. Quatro anos depois, em 1959, inicia-se a fase de expansão do empreendimento, cujas empresas Olvebra S.A (Lajeado, 1959), Rizóleo (Alegrete, 1964), Sorol (Pelotas, 1970) são adquiridas e modernizadas. Unificadas em 1972, juntamente com a Igol santa-rosense, passam a denominar-se Olvebra S.A. - Indústria e Comércio de Óleos Vegetais.

A década de 1970 representou o momento áureo da empresa, que se consolidou nos mercados nacional e internacional através da indústria de alimentos, embalagens metálicas, petroquímica, têxtil, fertilizantes, agropecuários, reflorestamento, seguros e agenciamento de turismo. No entanto, na década de 1980, a transferência da matriz para Porto Alegre transforma a unidade de Santa Rosa em simples recebedora da oleaginosa e produtora de óleo bruto e farelo de soja.

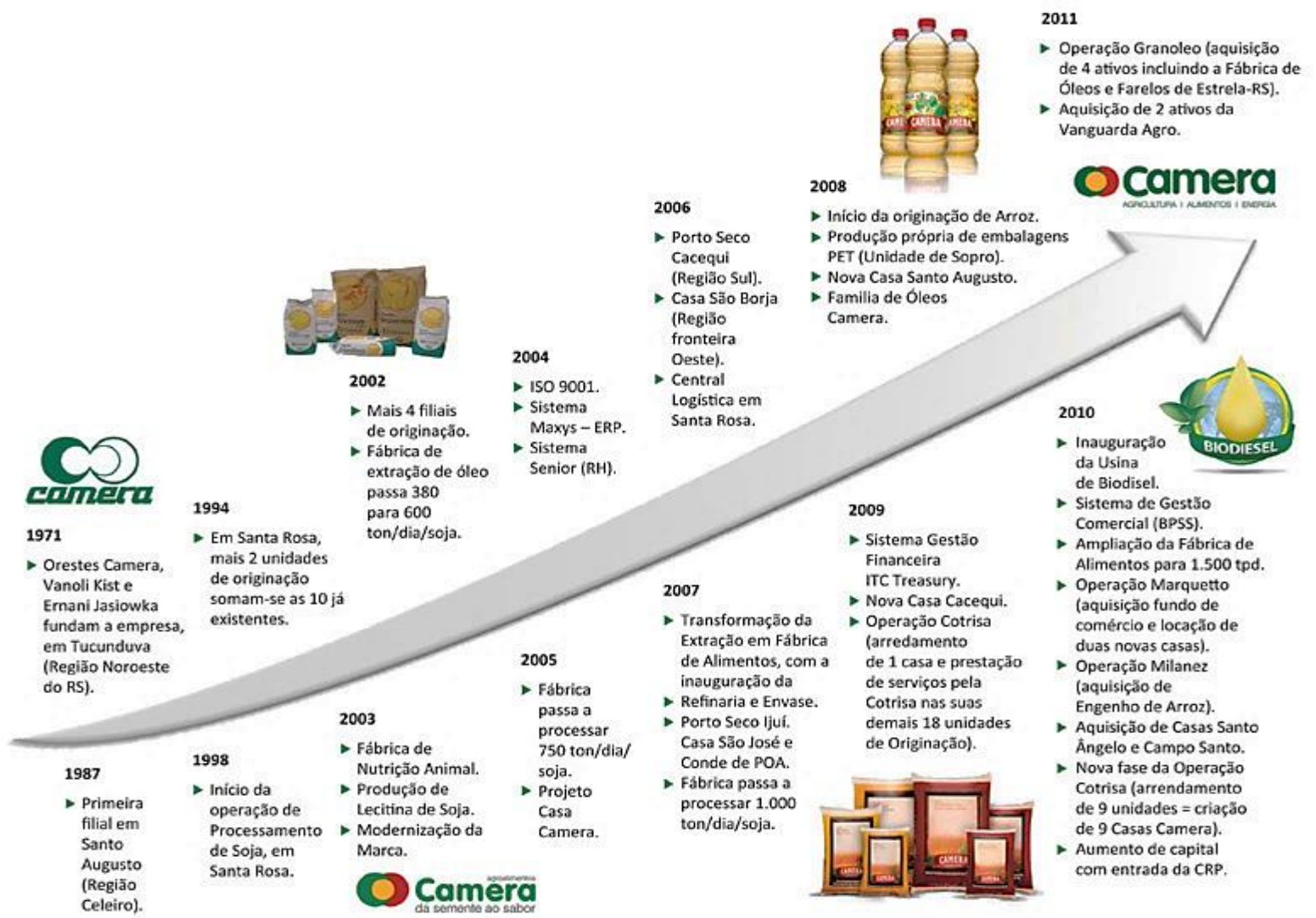

Figura 4.5.7. Esquema figurado mostrando a evolução da Camera.

Fonte: http://www.camera.ind.br/novo/a_compania/linha_do_tempo.php. 
A Olvebra expandiu-se também para a região de Guaíba, município próximo a Porto Alegre, e em 1971 torna-se uma empresa de capital aberto. De 1972 até 1985, a Olvebra S.A. marca a fase de diversificação com a criação de empresas e aquisição de novos tipos de empreendimentos. Transformou-se, nesse período, num conglomerado de mais de dez empresas espalhadas pelo Rio Grande do Sul, Paraná e São Paulo, lideradas pela holding Olvebra S. A. (Figura 4.5.7).

Após esse período, no início dos anos de 1990, a Olvebra encerra suas atividades em Santa Rosa gradativamente até fechar definitivamente no final de 1993. A planta industrial é adquirida pela Camera Agroalimentos S.A, em 1994, que remodelou suas instalações e reativou a fábrica de óleos vegetais na cidade, a partir de 1998.

A Camera está localizada no centro da cidade de Santa Rosa (Figura 4.5.8) e opera com capacidade de produção de 1.500 toneladas/dia que produz óleo, farelo, casca e lecitina, tem na refinaria de óleos vegetais o complemento final do processo da industrialização do óleo de soja e canola.

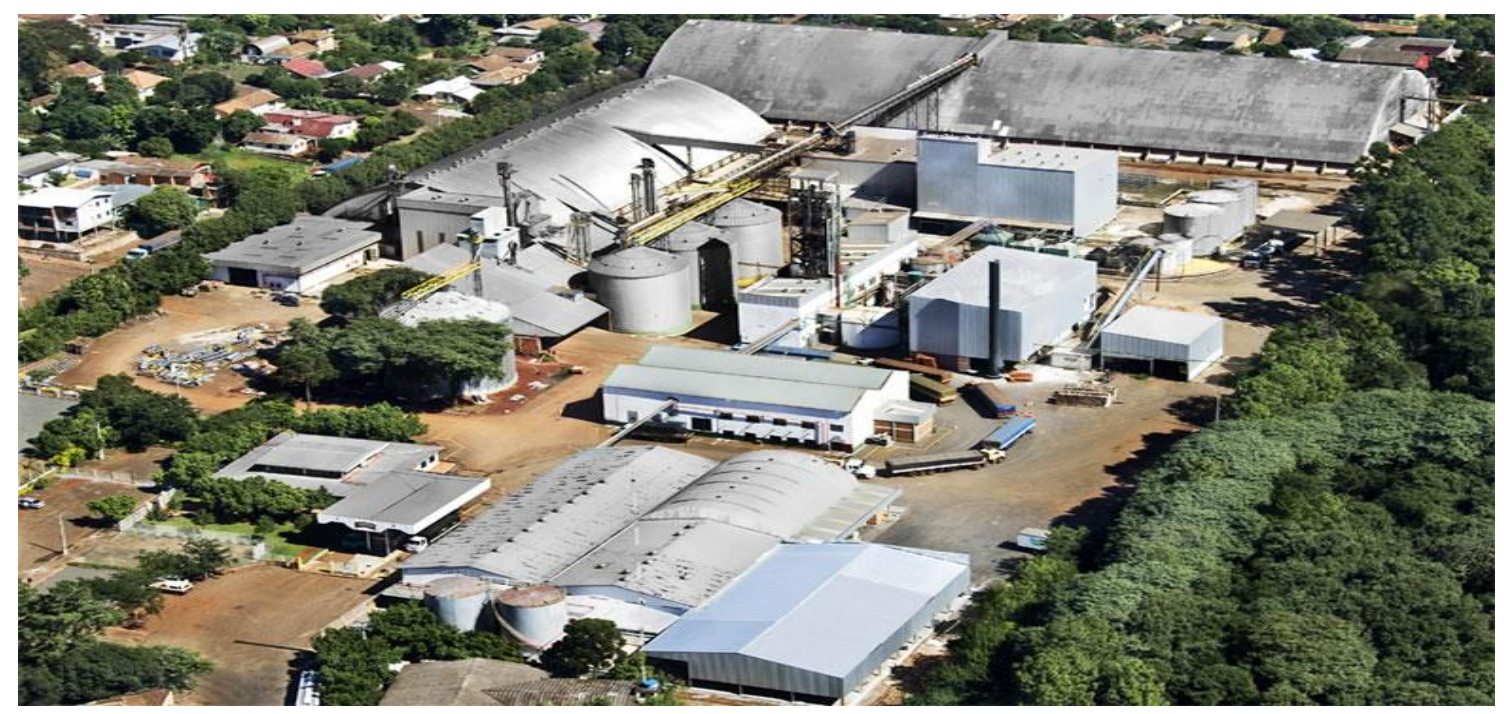

Figura 4.5.8. Vista aérea da Camera Agroalimentos em Santa Rosa.

Fonte: http://www.camera.ind.br/companhia/industria.php.

A marca está na atuação diversificada e verticalizada em toda a cadeia da agricultura, com unidades estratégicas de negócios nos diversos segmentos de mercado que formam o agronegócio. Para esses procedimentos a empresa conta com a atuação de 1.400 trabalhadores. Dentre as diversas atividades da empresa Camera, destacam-se: recebimento, secagem e armazenagem de soja, trigo, milho, canola, girassol e arroz; venda de insumos agrícolas: comercialização de sementes, fertilizantes e agroquímicos; 
rações: na linha de bovinos, suínos, aves, ovinos, equinos, peixes, coelhos e avestruzes, além de comercializar também concentrados e sais minerais; lubrificantes e diesel; prestação de serviços, como tratamento de sementes e projetos agropecuários e assistência técnica.

Considerando o potencial agrícola nas diversas regiões brasileiras, sobretudo, relativo às Regiões Sul, Sudeste e Centro-Oeste, argumenta-se que o Brasil é um país altamente propenso ao desenvolvimento do agronegócio, pois demonstrou capacidade em várias cadeias de agronegócio, como o complexo produtivo da soja, o de suínos e do gado vacum leiteiro, com um potencial de desenvolvimento para uma série de outras cadeias agroalimentares. Zamberlan et al. (2010, p. 22) salientam que o Brasil possui condições efetivas de se tornar um dos principais fornecedores mundiais de alimentos.

Notadamente, o agronegócio é caracterizado pelas indústrias que processam ou beneficiam produtos oriundos do setor primário, sejam eles agrícolas ou pecuários. Entre as agroindústrias destacam-se os complexos agroindustriais de empresas públicas e privadas, como moinhos, cerealistas, frigoríficos e abatedouros; agroindústrias de derivados de leite, agroindústrias de conservas etc. Também existe uma grande quantidade de indústrias consideradas no agronegócio ao longo da cadeia produtiva, como a metalmecânica e a moveleira, todas elas com representação acentuada na região Fronteira Noroeste.

O agronegócio é hoje a principal locomotiva da economia brasileira e responde por um em cada três reais gerados no País. É responsável também por grande parte do PIB das exportações totais e dos postos de trabalho. Nos últimos anos, poucos países tiveram um crescimento tão expressivo no comércio internacional do agronegócio quanto o Brasil. Em dez anos, o país dobrou o faturamento com as vendas externas de produtos agropecuários e teve um crescimento superior a 100\% no saldo comercial. Esses resultados levaram a Conferência das Nações Unidas para o Comércio e Desenvolvimento (Unctad) a prever que o país tem vocação para ser o maior produtor mundial de alimentos (ZAMBERLAN et al., 2010, p. 23).

Inserida na área geográfica em que se processou o início e as maiores produtividades da soja no primeiro período dessa cultura agrícola no Brasil, já em 1966, em Santa Rosa, a Feira Nacional da Soja - Fenasoja vem se consolidando no agronegócio brasileiro com o "complexo soja". Com o advento da feira, que se encontra 
atualmente na sua vigésima edição, foi-se aprimorando o melhoramento de grãos, a genética leiteira e o aporte em tecnologias direcionadas ao segmento metalmecânico, permitindo aproveitar melhor o potencial de uso da terra. Consolidada como uma das maiores feiras agropecuárias do Estado e do Brasil, a Fenasoja, que acontece de dois em dois anos, congrega em um mesmo ambiente indústria, comércio, pecuária, agricultura e tecnologia com o intuito de potencializar a economia local e elevar o nome do município e região para além de suas fronteiras. (Figuras 4.5 .9 e 4.5.10).

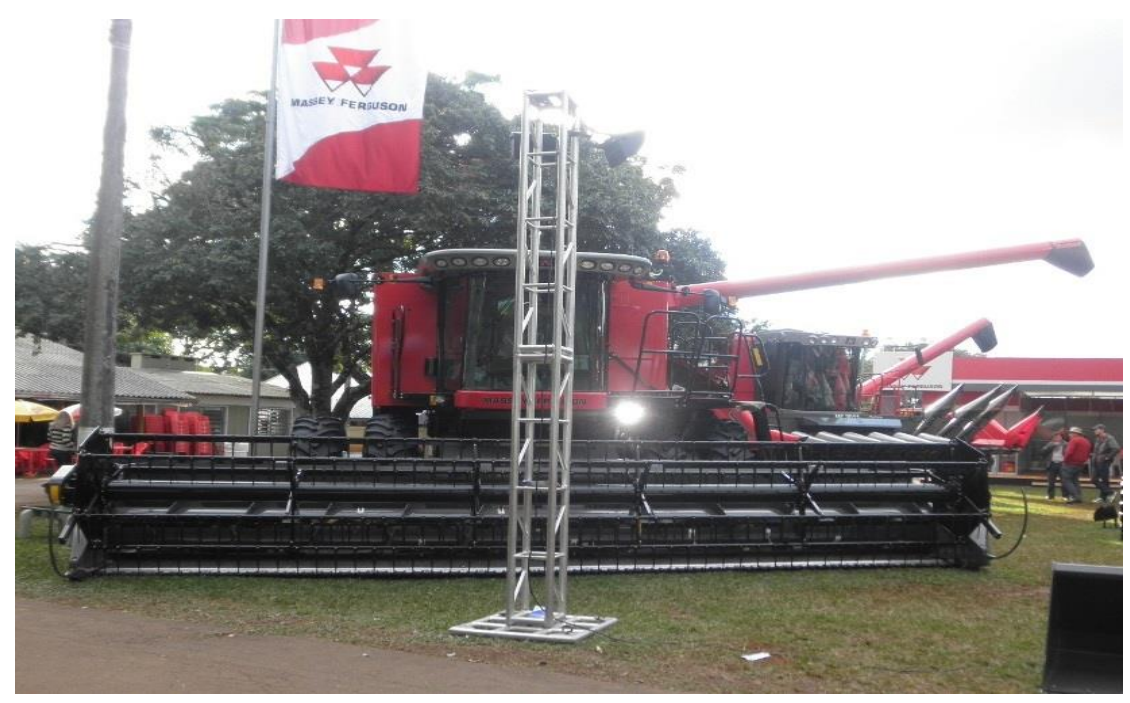

Figura 4.5.9. Massey Fergusson, na Feira Nacional da Soja em Santa Rosa.

Fonte: $\mathrm{O}$ autor.

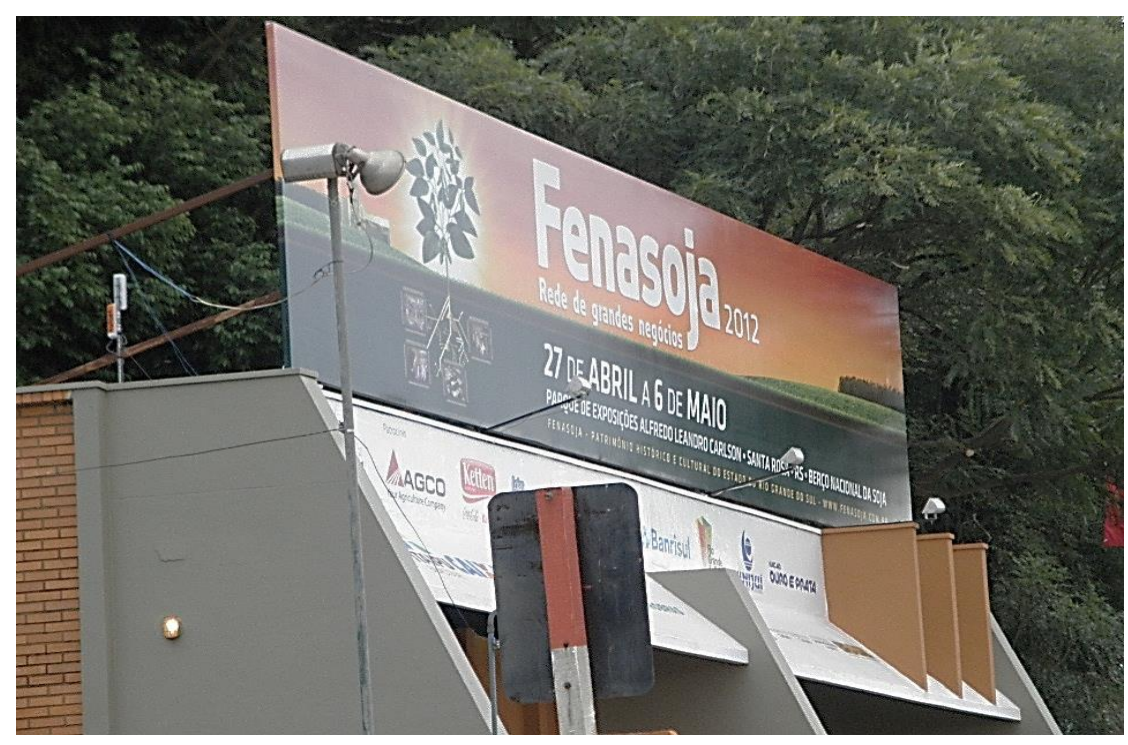

Figura 4.5.10. Outdoor (mídia) da Feira Nacional da Soja de 2012 em Santa Rosa.

Fonte: $\mathrm{O}$ autor. 
Excluindo-se a indústria alimentar, a Região Fronteira Noroeste, representada principalmente pelos municípios de Santa Rosa e Horizontina, originou, desenvolveu e promoveu, a partir de meados do século passado, um segmento industrial muito expressivo que sempre auxiliou no processo de geração de sua renda: o segmento metalmecânico. Esse tipo de indústria fez da região uma área polo que confecciona componentes importantes utilizados por grandes empresas em torno da demanda produtiva de colheitadeiras.

Há mais de cinco décadas, surgia, em 1945, a firma Schneider Logemann \& Cia. Ltda, que deu origem à marca SLC, no município de Horizontina, quando Balduíno Schneider e Frederico Logemann constituíram uma sociedade em torno de uma oficina mecânica destinada a atender às necessidades dos pequenos agricultores da região no conserto de ferramentas de trabalho. A partir destas atividades os sócios resolveram instalar, em 1947, uma pequena ferraria e uma carpintaria rudimentar. Com a instalação da ferraria tornou-se possível a "fabricação de máquinas singelas destinadas ao beneficiamento da madeira, tais como serras circulares, serras de fita e lixadeiras, além de alguns implementos agrícolas e de extração vegetal" (EMPRESAS, 1995, p. 3, apud FRANTZ et al., 2008, p. 50).

Ainda em 1947, a SLC produziu sua primeira trilhadeira de cereais, produto que iria se tornar, rapidamente, o seu principal negócio. Em 1957, a SLC inova com a fabricação da ceifa-trilhadeira SLC - Modelo A-180, popularmente conhecida como "ceifa reboca", pois utilizava a força motriz de um trator para funcionar e para ser movimentada, constituindo-se em ganho importante para viabilizar o passo seguinte, que foi a fabricação de colheitadeiras automotrizes (ceifadeiras), a partir de 1965. Até então as trilhadeiras tinham sido o principal foco da empresa, mudando gradativamente para a fabricação crescente de ceifadeiras e plantadeiras (FRANTZ et al., 2008).

As perspectivas, em torno de expansão da produção de grãos no Brasil, eram boas desde a década de 1950, motivadas pelo apoio estatal. A área cultivada com cereais crescia constantemente no RS exigindo, a cada ano, um maior número de máquinas e implementos agrícolas. Com a introdução da soja, a partir dos anos de 1960, em escala maior, a demanda por máquinas foi decisivamente impulsionada. Nessa fase havia recursos públicos abundantes para investimentos e custeios.

Desse modo,

a experiência em colheitadeiras foi sendo conquistada no campo de batalha. O surgimento de grandes lavouras de trigo permitiu que a 
SLC se familiarizasse com as colheitadeiras automotrizes importadas e o conhecimento adquirido reforçava a determinação de construí-las (EMPRESAS, 1995, p. 75, apud FRANTZ et al. 2008, p. 54).

Uma vez construída a primeira colheitadeira, em 1965, denominada de 65 - A, o ritmo de expansão de capacidade produtiva foi bastante acelerado. Em 1966, foram produzidas na empresa 12 máquinas; em 1973 já eram 1.036 e em 1976 passavam de 2.000. A participação da SLC no mercado brasileiro de máquinas agrícolas chegou, no período, a ser de mais de $30 \%$.

Com o passar dos tempos a SLC se associou à John Deere:

A marca John Deere entra efetivamente no Brasil em 1979 quando adquire $20 \%$ do capital social da SLC S.A. - Indústria e Comércio, transferindo tecnologia para a fabricação de novas colheitadeiras. Em 1996, a empresa introduz sua linha de tratores no País com a marca SLC - John Deere, [Figura 4.5.11 e 4.5.12] aumentando sua participação para 40\%. Finalmente em 2001, adquire o total das ações de SLC S.A. - Indústria e Comércio (FRANTZ et al., 2008, p. 52).

A união entre a empresa norte-americana John Deere e a brasileira SLC perfaz mais de 30 anos. No mercado há mais de 60 anos, exerce expressiva participação no setor de máquinas e implementos agrícolas, a SLC introduziu o conhecimento tecnológico e penetração no agronegócio brasileiro pela sua base industrial no município de Horizontina, no Corede Fronteira Noroeste do RS (Figuras 4.5.11 a 4.5.16).

As máquinas fabricadas para o mercado brasileiro e internacional agregavam as vantagens de uma empresa globalizada. De um lado pela fonte tecnológica e, de outro, pelo amplo conhecimento das necessidades dos mercados regionais. Atualmente a unidade John Deere Brasil é responsável por $60 \%$ das exportações brasileiras de colheitadeiras. As máquinas produzidas em Horizontina respondem por 50\% da colheita de grãos no país (BRUM et al. 2008, p. 73). 


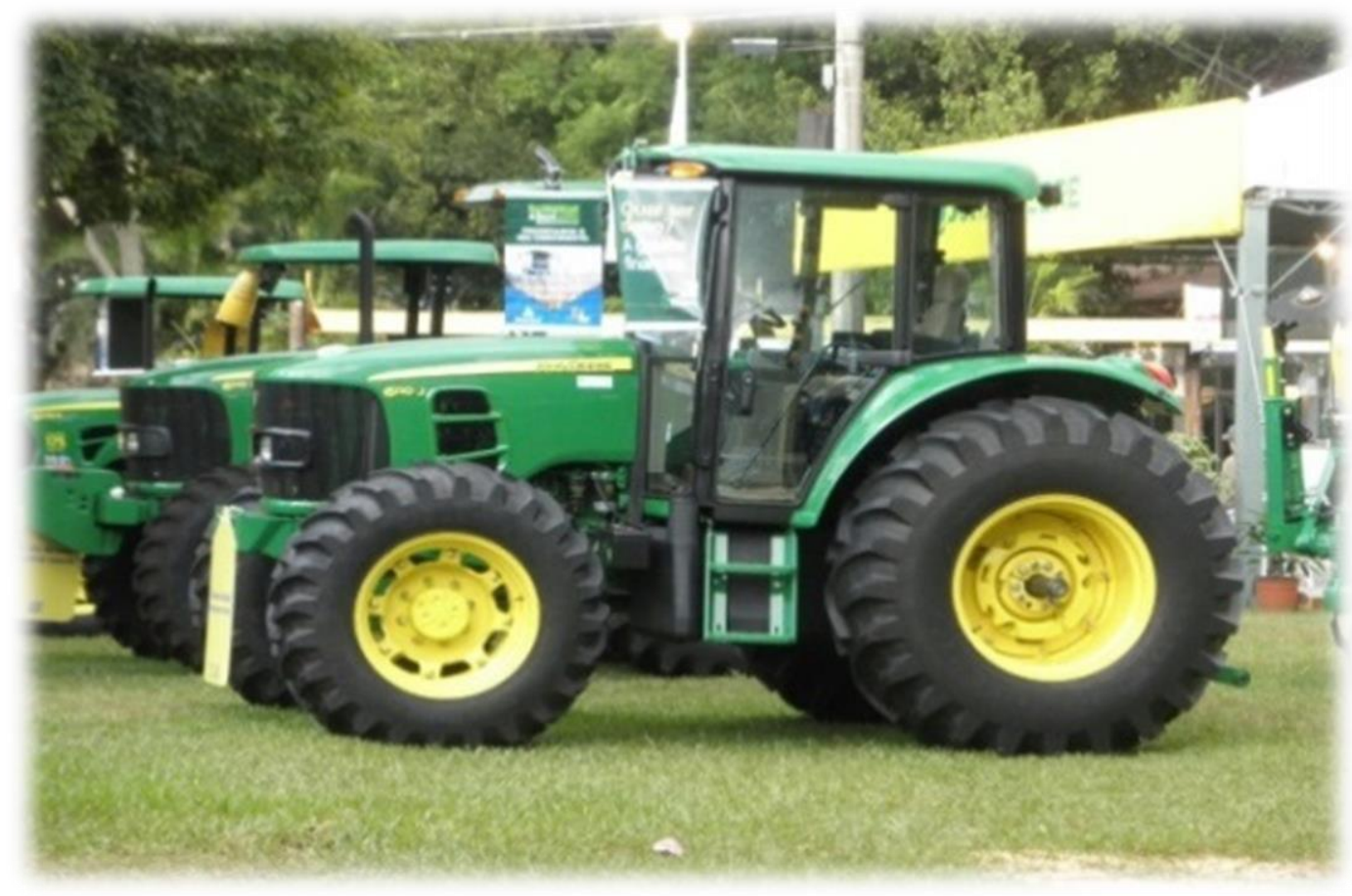

Figura 4.5.11. Tratores John Deere.

Fonte: $\mathrm{O}$ autor

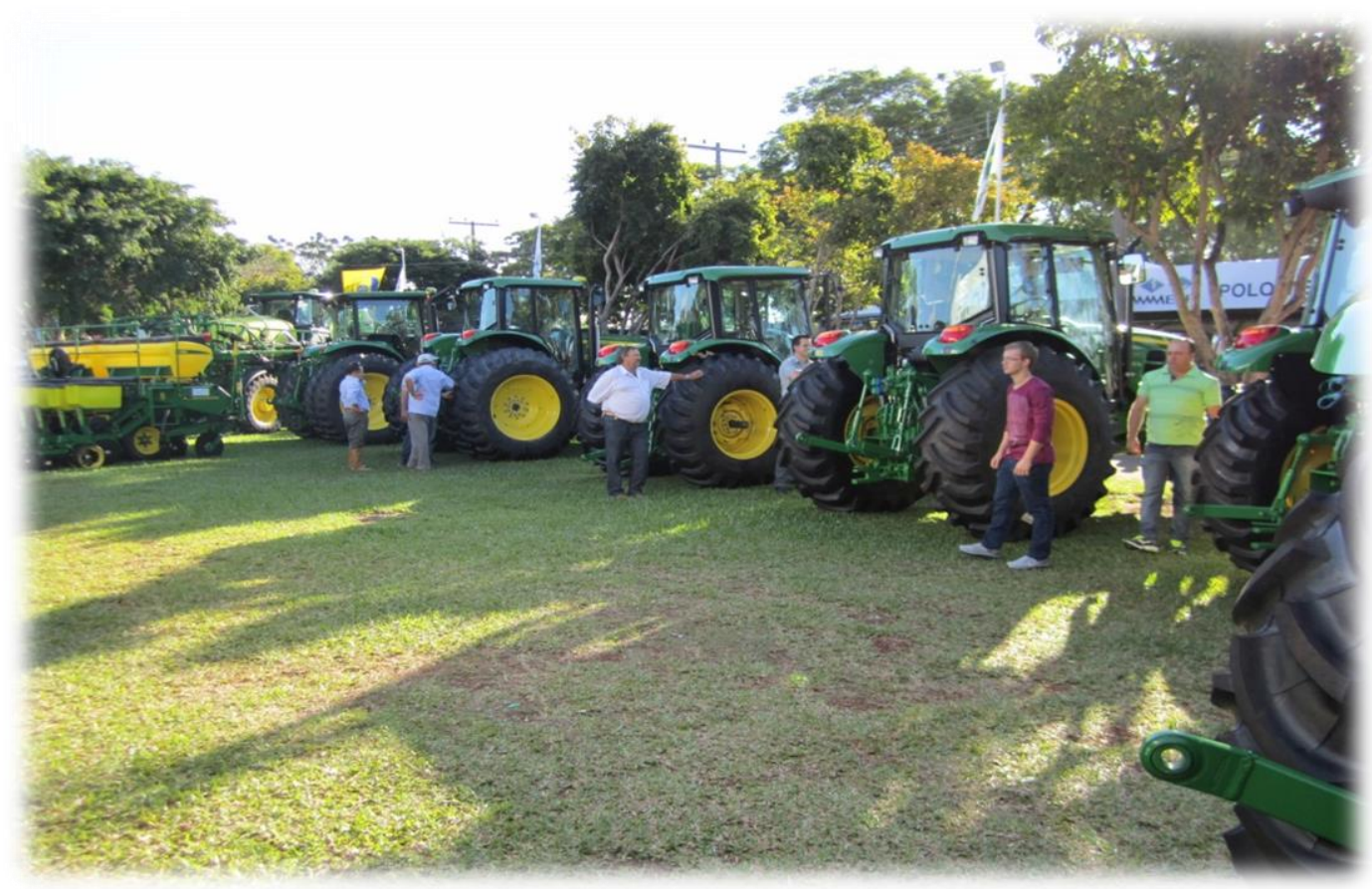

Figura 4.5.12 Tratores John Deere.

Fonte: $\mathrm{O}$ autor 
A John Deere é lider mundial na fabricação de equipamentos agricolas, que inclui centenas de modelos em sua linha de produção, que inclui tratores, implementos para o preparo do solo, plantadeiras, cultivadores mecanicos, pulverizadores, colheitadeiras de grãos e de algodão e equipamentos para fenação e ensilagem, tudo isso dividido em células de manufaturas em mais de 30 unidades fabris da empresa.

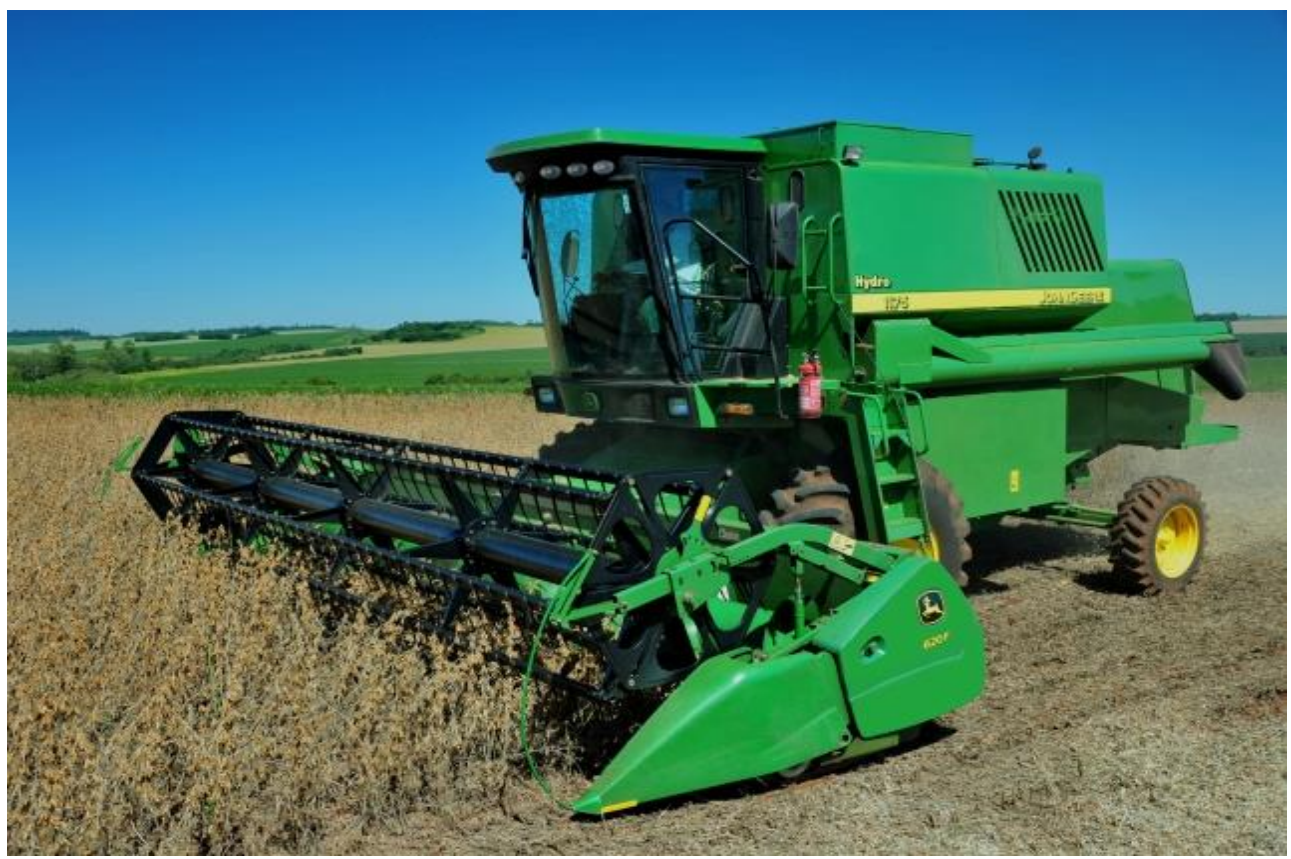

Figura 4.5.13. Modelo de colheitadeira produzido pela John Deere.

Fonte: www.deere.com.br, 2014.

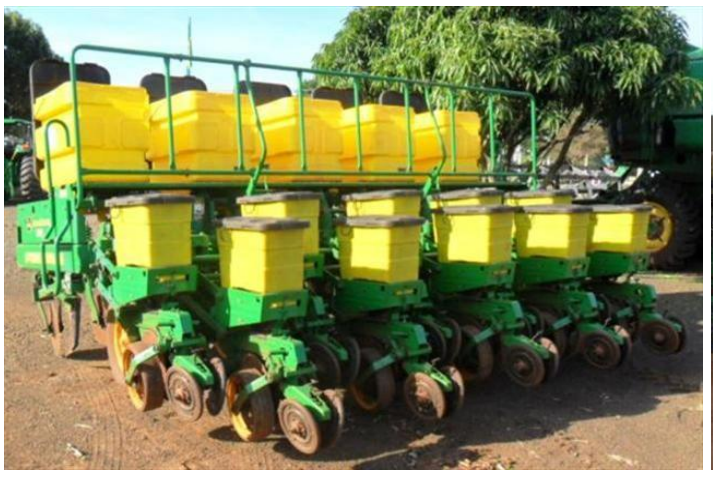

Figura 4.5.14. Plantadeira John Deere

Fonte: www.deere.com.br, 2014

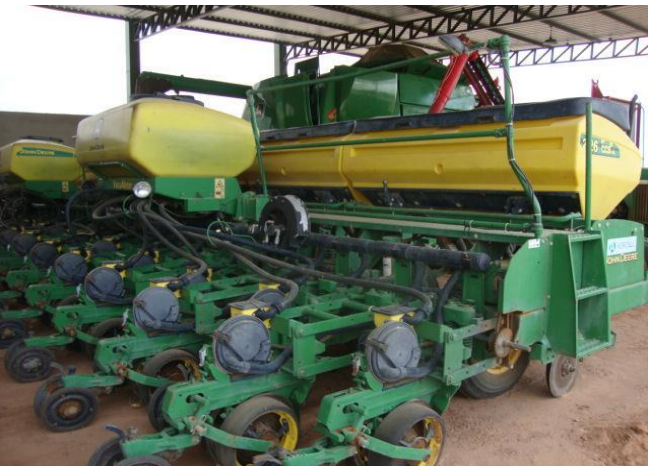

Figura 4.5.15. Plantadeira John Deere

Fonte: www.deere.com.br, 2014 


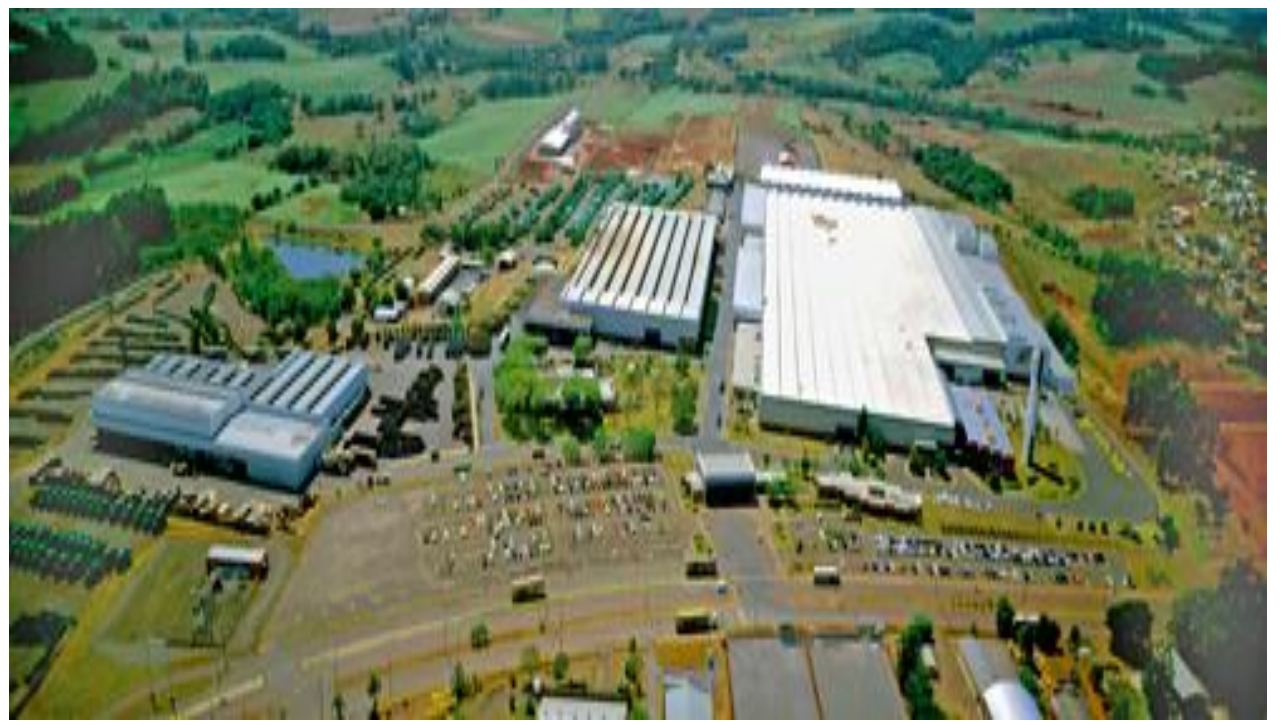

Figura 4.5.16. Vista aérea da John Deere de Horizontina, Fronteira Noroeste.

Fonte: http://www.portalmaquinasagricolas.com.br

A produção inicial de colheitadeiras no município de Santa Rosa deu-se entre os anos de 1950 e 1960; contudo, ainda se não dispunha de tecnologia satisfatória. A partir do aumento do cultivo da soja, na década de 1960, a cidade passou a produzir trilhadeiras com a marca Ideal. Em 1968, a equipe técnica da Indústria de Máquinas Agrícolas Ideal produziu sua primeira colheitadeira automotriz. Já em meados dos anos de 1970, o empresário Felipe Streich se mostrava confiante em promover no município investimentos para melhoramento tecnológico na manufatura de máquinas e de implementos agrícolas. Streich objetivava construir a melhor colheitadeira do mundo e para tanto havia a necessidade de contratação de técnicos profissionais de alto nível vindos de países vizinhos ao Brasil, bem como da Espanha, para ajudar no desenvolvimento e nacionalização da tecnologia.

O aporte de tecnologia à empresa era fornecido por um grupo alemão de renome, que detinha cerca de 30\% do capital da Ideal. Em 1973, a empresa passou à condição de sociedade anônima desencadeando um processo de alienação do controle acionário que, em 1978, passou para o Grupo Iochpe.

Alternando altos e baixos, a empresa viveu seus momentos áureos no final da década de 1970 e, por períodos intercalados, na década de 1980 e no começo dos anos de 1990. A década de 1990 trouxe novas dificuldades em função da crise da agricultura em nível local e nacional, o que a levou buscar novas parcerias alternativas. Implantou um processo de terceirização que reduziu seu quadro funcional pela 
metade, incentivando a fundação de vários estabelecimentos metalúrgicos de pequeno porte (Figura 4.5.17 e 4.5.18) que passam a trabalhar como fornecedores de componentes (ROTTA, 1999, pp. 8586).

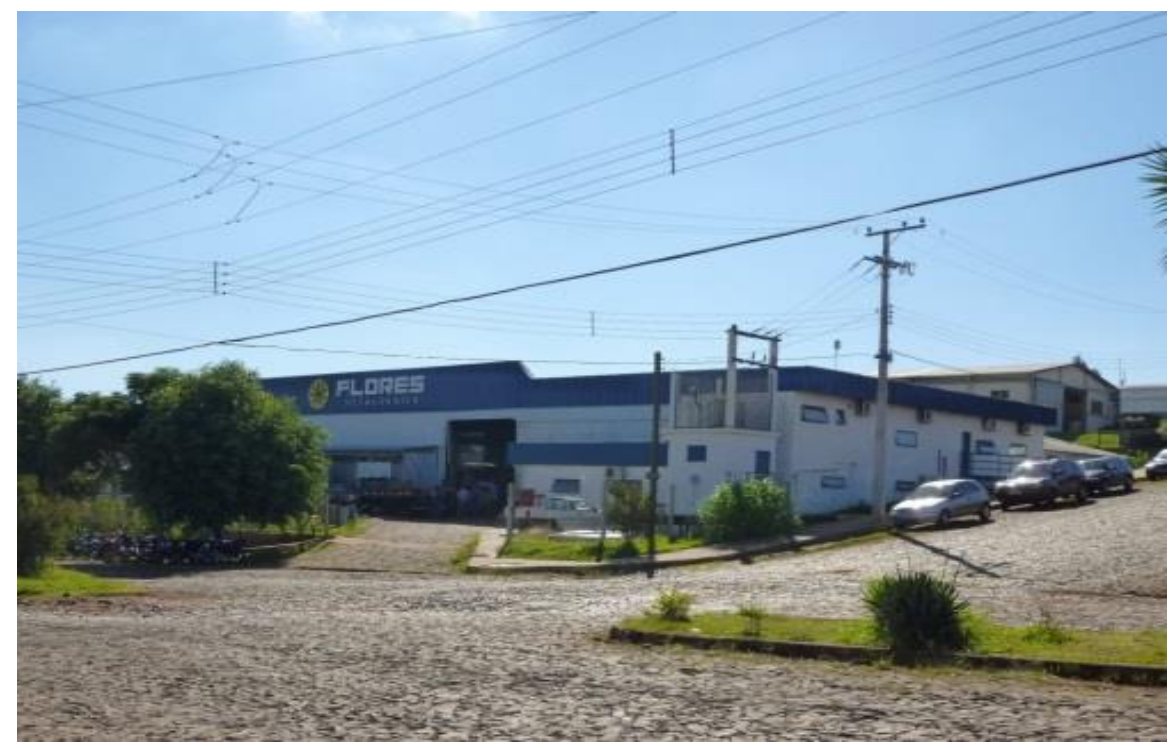

Figura 4.5.17. Empresa metalmecânica sistemista do distrito industrial.

Fonte: o autor

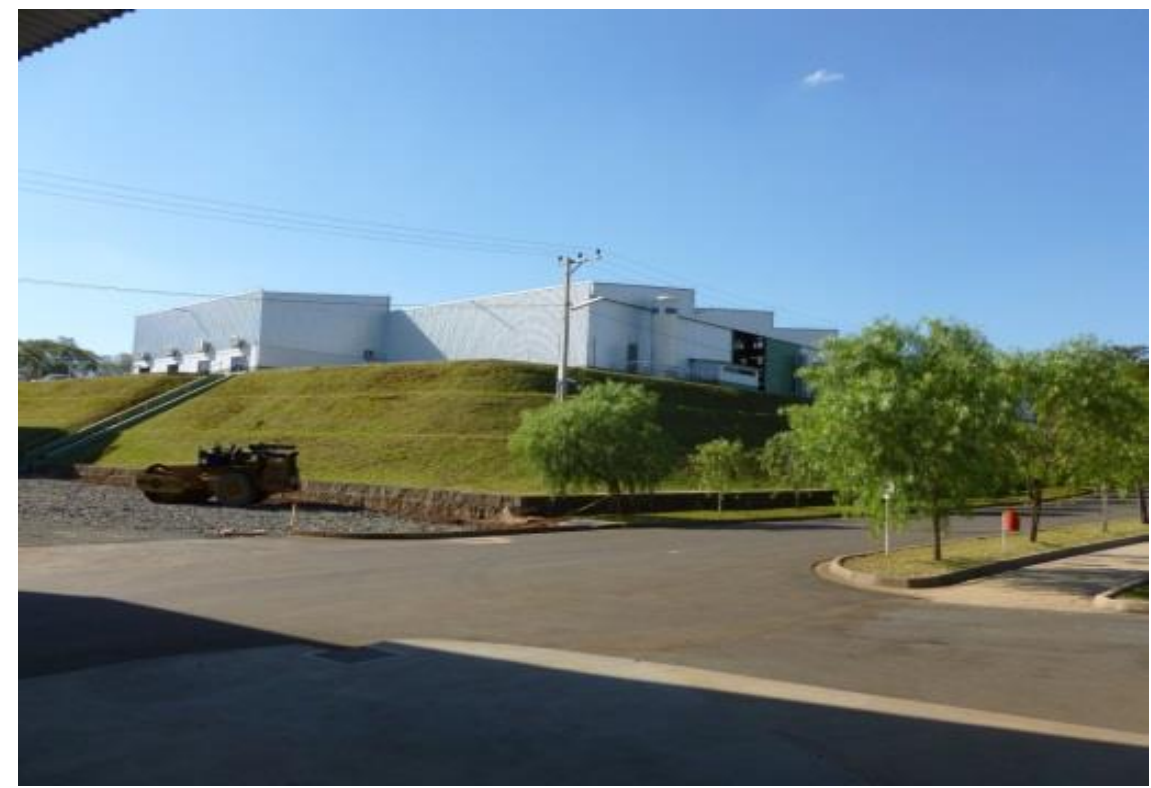

Figura 4.5.18 Empresa metalmecânica sistemista do distrito industrial.

Fonte: o autor

$\mathrm{Na}$ procura por novas parcerias, a Iochpe associou-se ao Grupo Massey Ferguson, passando a denominar-se Iochpe-Maxion e, posteriormente, AGCO do Brasil 
Comércio e Indústria Ltda. Chegou a ter mais de 1.200 funcionários, hoje, reduzidos a oitocentos metalúrgicos. No final de 1998, passou por novo processo de reestruturação para adequar-se às novas exigências do mercado de máquinas e implementos agrícolas.

O segmento metalmecânico, que aos poucos vai ganhando consistência e importância no cenário municipal, afirma-se como um dos mais importantes, passando de um crescimento inicial em cerca de $20 \%$ das indústrias nos anos de 1970 para quase $25 \%$ no final dos anos de 1980, empregando um contingente considerável de trabalhadores (FIDENE, 1993).

Fruto do desenvolvimento do segmento alimentar que, de fato, percorre toda a trajetória econômica do município de Santa Rosa e região - haja vista que tanto a agricultura quanto a pecuária foram as principais indutoras para a fundação das primeiras instalações fabris, quais sejam, as indústrias alimentícias - o importante segmento metalmecânico do município polo da Fronteira Noroeste do RS se coloca como a segunda etapa, bem sucedida, de uma industrialização originalmente de cunho artesanal. Atualmente, esse segmento industrial produz máquinas e implementos capazes de tornar mais rápido o processo produtivo geral e dar-lhe maior qualidade, desde o preparo do solo, passando pelo plantio, o manuseio e a colheita, até o transporte, o armazenamento e a posterior comercialização até a chegada do produto ao consumidor. O pioneirismo nesta área rio-grandense é internacionalmente reconhecido

Devido ao processo de terceirização promovido na região a partir dos anos de 1990, hoje existem mais de 50 empresas que estão integradas de forma vertical, fornecendo componentes dos mais variados tipos para as empresas responsáveis pela produção de maquinário, neste caso, a John Deere (4.5.16) e a AGCO (Figura 4.5.19) do Brasil.

As empresas deste segmento industrial geram aproximadamente nove mil empregos diretos na região, especialmente nos núcleos de Santa Rosa e Horizontina. Este arranjo produtivo articula-se com as Associações Comerciais e Industriais locais, com as Agências de Desenvolvimento e com os Conselhos Municipais e Regionais de Desenvolvimento. Da mesma forma está também inter-relacionada com as representações locais, regionais, estaduais e nacionais da categoria (os sindicatos de classe), quer seja em nível empresarial como dos trabalhadores (BUTTEMBENDER, 2010, p.80). 


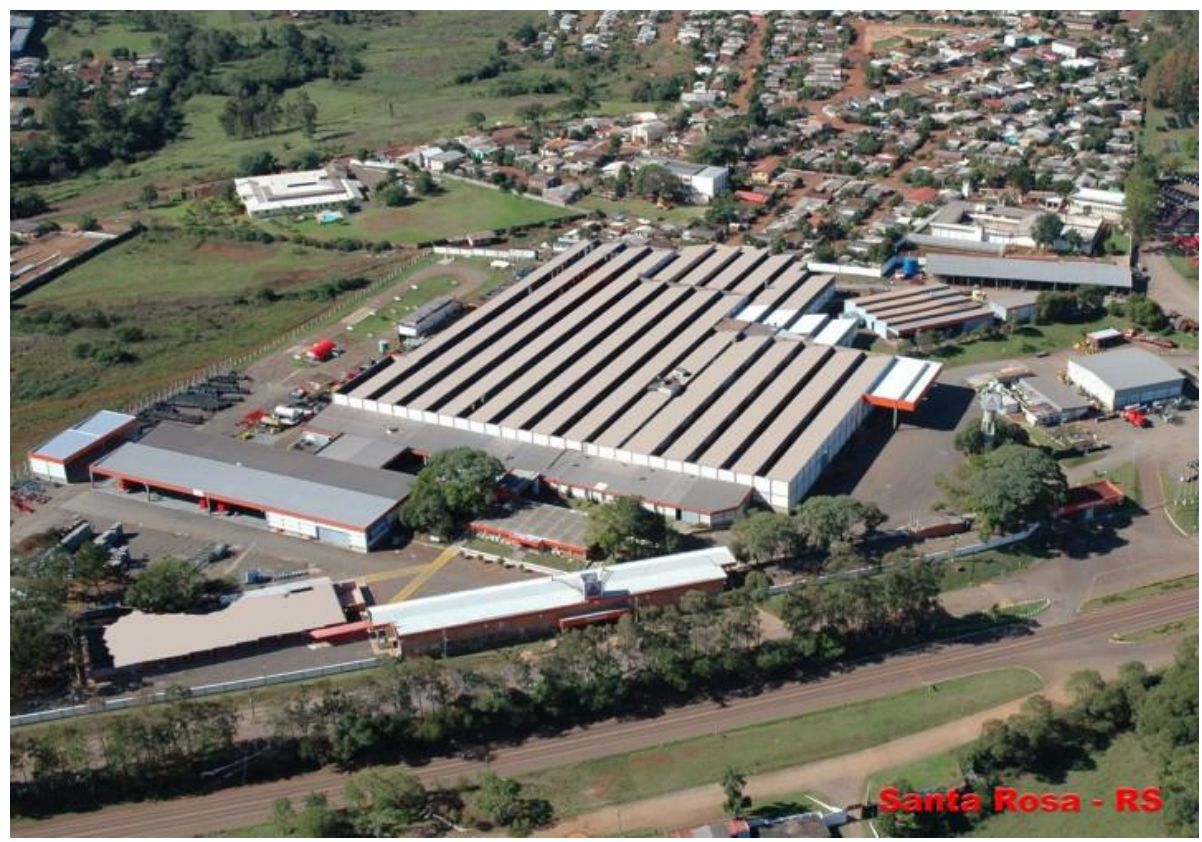

Figura 4.5.19. Vista aérea da instalação e da linha de produção da AGCO de Santa Rosa.

Fonte: Prefeitura Municipal de Santa Rosa, 2013.

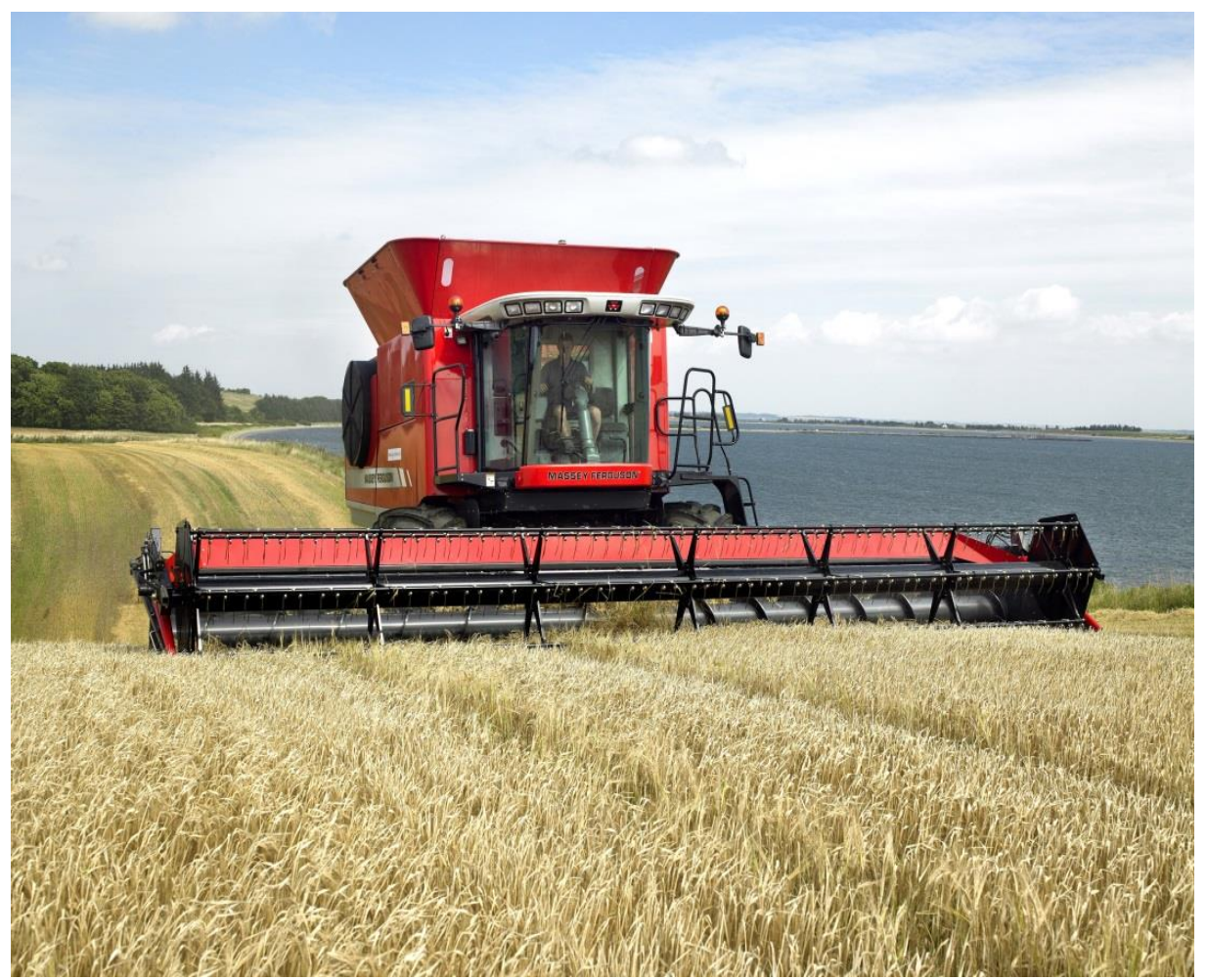

Figura 4.5.20. Colheitadeira Massey Fergusson

Fonte: http://www.massey.com.br/produtos/colheitadeiras/axiais, 2014 


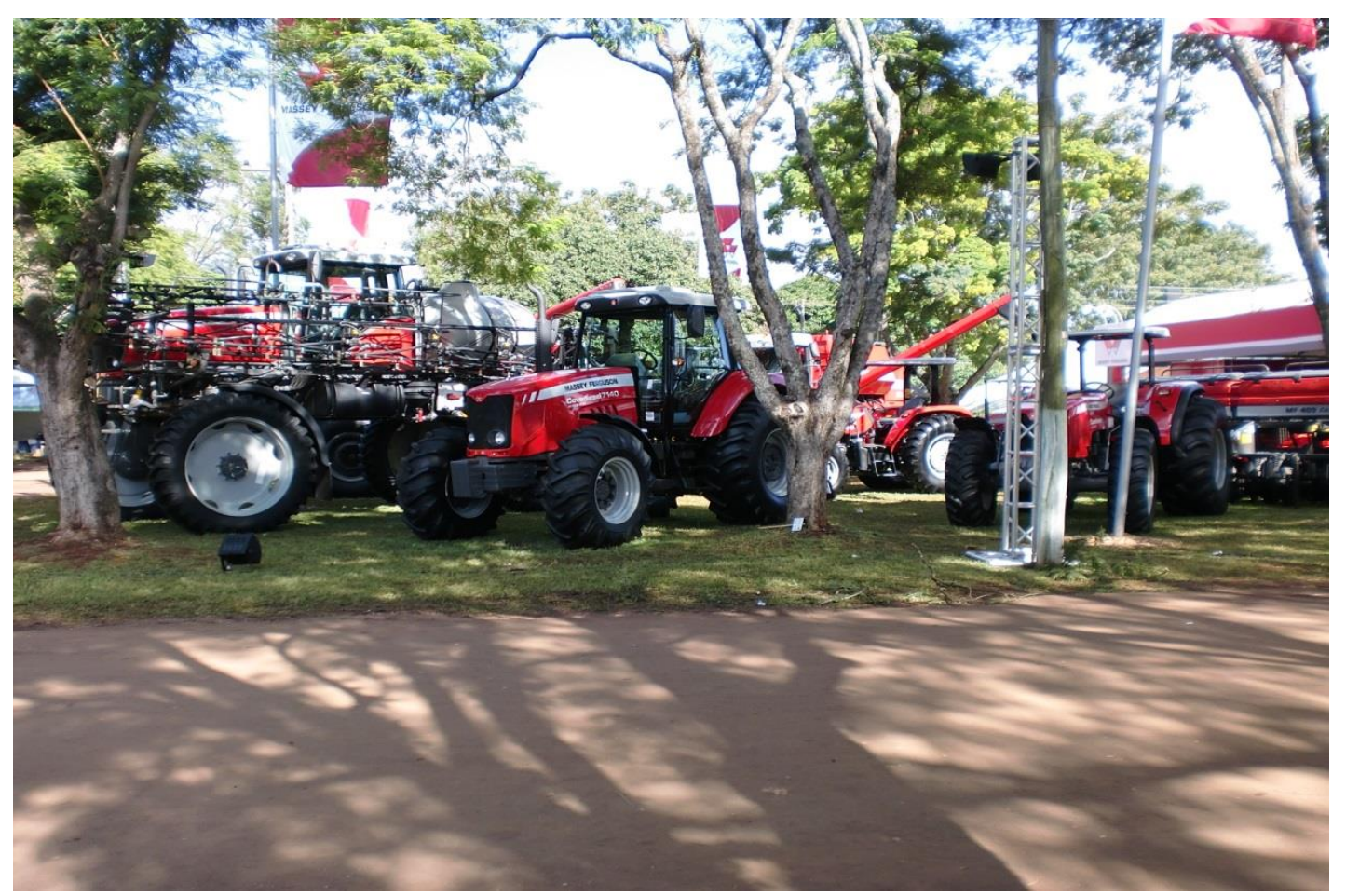

Figura 4.5.21. Tratores Massey Ferguson

Fonte: $\mathrm{O}$ autor

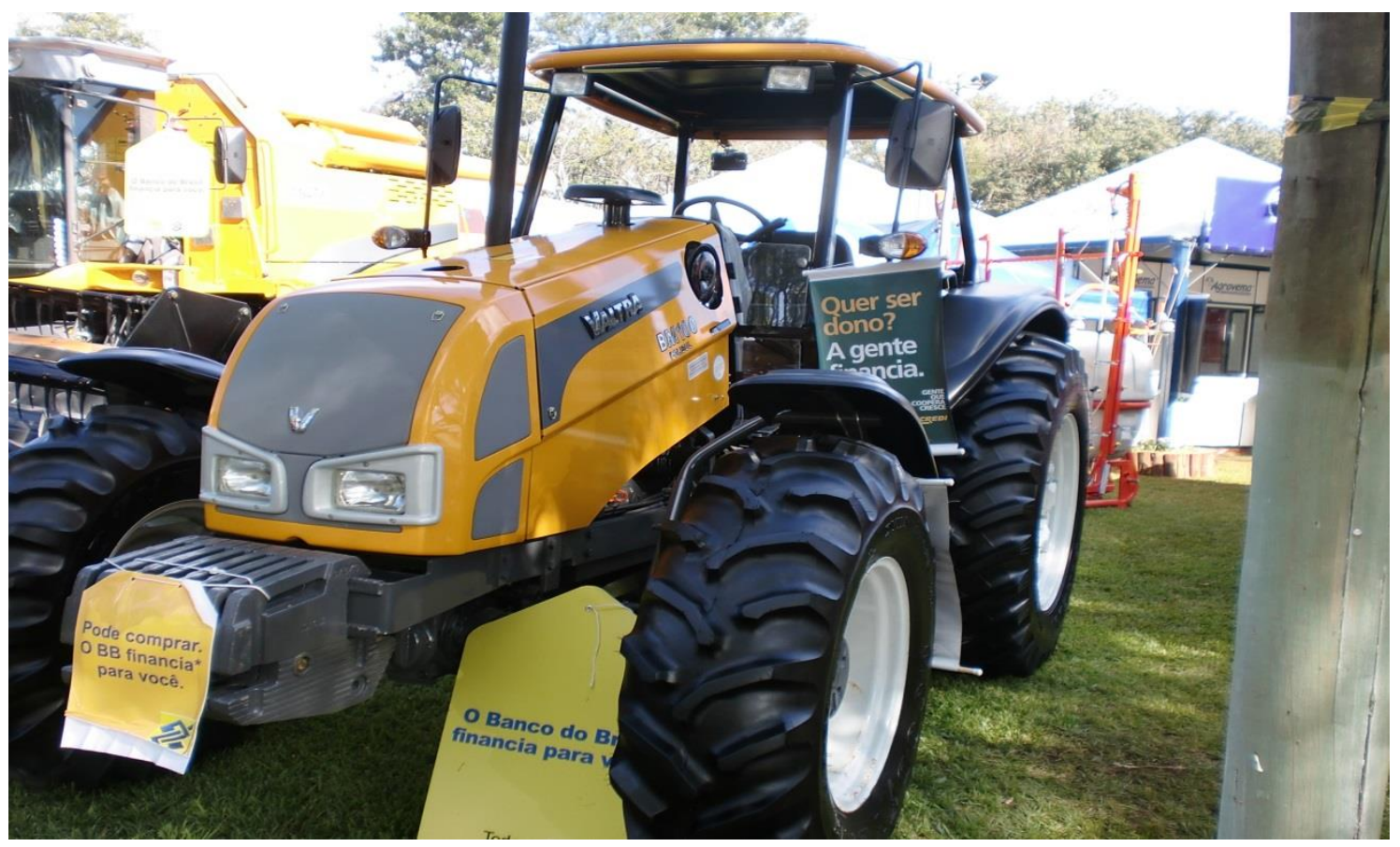

Figura 4.5.22. Tratores Valtra

Fonte: $\mathrm{O}$ autor 
O apoio das administrações municipais, de instituições de ensino profissionalizante e de instituições voltadas ao apoio de pequenos empreendimentos existentes na região ajudou a alavancar a expansão e qualificação do setor. As empresas do polo metalmecânico da região desenvolveram sistemas que asseguram a qualidade das peças e ferramentas produzidas. Grande é o número de empresas certificadas de acordo com as normas ISO, que conferem maior confiabilidade a seus produtos e serviços, como por exemplo, a empresa Fankhauser S.A. (Figura 4.5.23) produtora de implementos agrícolas, com sede no município de Tuparendi.

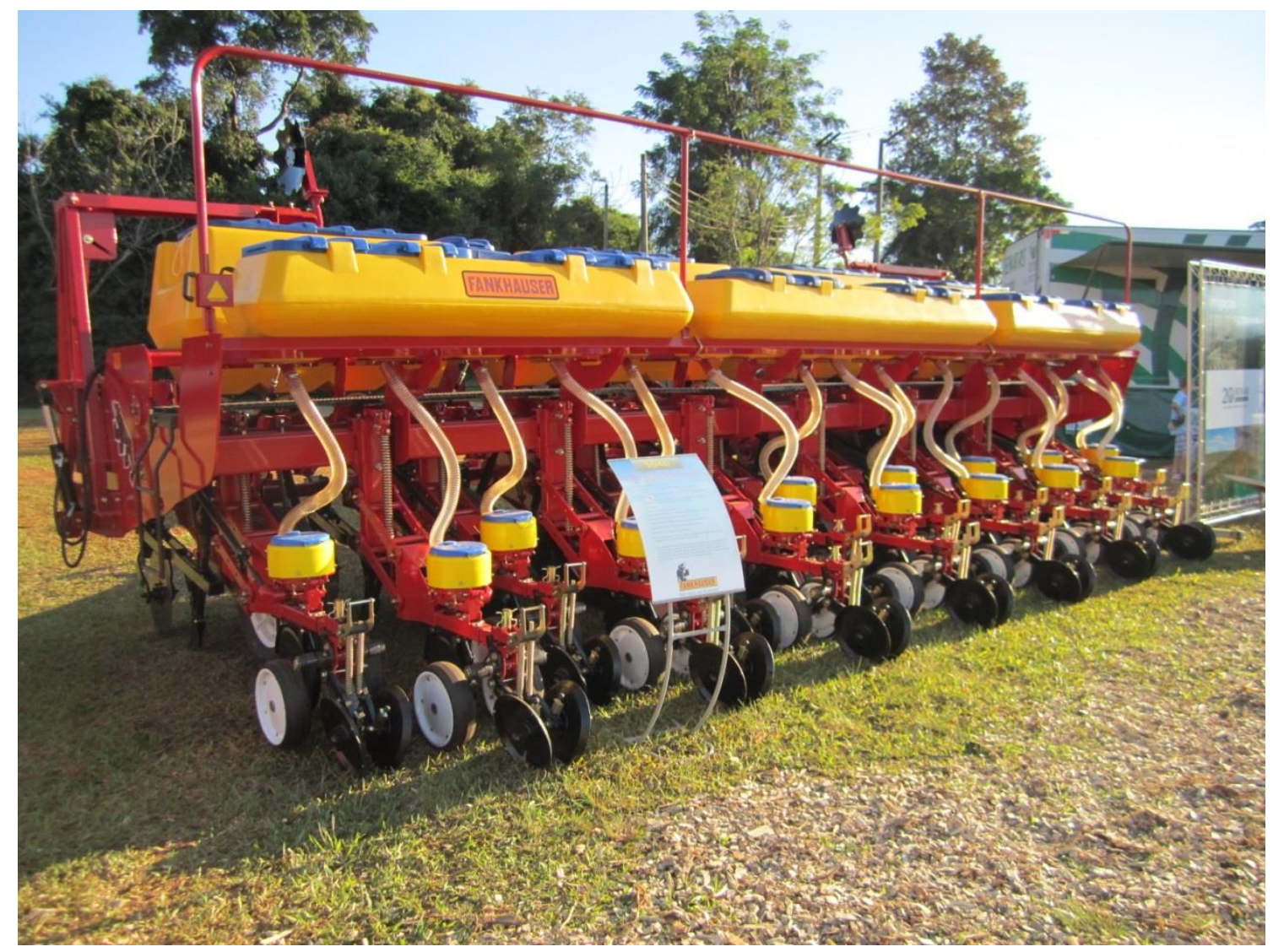

Figura 4.5.23. Implemento agrícola produzido pela Fankhauser em Tuparendi.

Fonte: $\mathrm{O}$ autor.

De todas as empresas atuando no Brasil, mais de $60 \%$ das fábricas de máquinas e implementos agrícolas estão instaladas no Rio Grande do Sul. Três empresas respondem por quase metade da produção nacional de tratores de rodas (Figuras 4.5.11, 4.5.12, 4.5.21 e 4.5.22), plantadeiras e colheitadeiras e retroescavadeiras (Figuras 4.5.13, 4.5.14, 4.5.15 e 4.5.20). O RS concentra um terço da força de trabalho do país nesta indústria (Governo do RS, 2010-2014). 


\subsection{POLÍTICA INDUSTRIAL}

Com o intuito de articular diversos segmentos do conjunto da sociedade entram em cena tentativas de revitalização do parque fabril em abrangência nacional e estadual. Nesse momento criam-se as políticas industriais.

A política industrial é uma forma de coordenar ações estratégicas de governo, empresas e instituições visando ao desenvolvimento de determinadas atividades ou a solução de problemas identificados por esses atores no setor produtivo da economia. Embora seu foco seja a indústria, a política industrial tem uma área de abrangência bastante estendida (SUZIGAN; FURTADO, 2006).

O desempenho das empresas industriais é afetado por inúmeros fatores, sejam eles tributários, tecnológicos, de planejamento ou de outra natureza. Conforme preconizam Suzigan e Furtado (2006), esses fatores influem na capacidade de competição das empresas, sendo o grande desafio delas a coordenação de ações abrangentes. A melhor maneira de enfrentar tal desafio parece ser o traçar uma estratégia de desenvolvimento com foco na indústria e a utilização de uma política industrial como um mecanismo de coordenação que valha para os três planos de governo: o federal, o estadual e o regional.

O desenvolvimento regional é uma das dimensões mais relevantes da política industrial, ainda mais quando se trata de um país com grandes dimensões como o Brasil, onde ocorrem enormes disparidades, que têm determinantes históricos, institucionais e produtivos vinculados a recursos naturais e às atividades econômicas primárias das regiões, além de condicionantes sociais, culturais e políticos que influem nas tendências econômicas das regiões. Para Suzigan e Furtado (2006), não é a política industrial que determina a distribuição regional da produção em geral e das atividades industriais em particular, mas ela faz o potencial de cada região ser aproveitado ainda melhor e até mesmo descobrir novas vocações regionais, mudando o padrão de vantagens competitivas de regiões.

A Política Industrial, Tecnológica e de Comércio Exterior - PITCE, da ordem do Governo Federal, constitui-se como uma forma organizada de atuação do governo para promover o desenvolvimento local/regional. Nesse sentido, em sua dimensão regional a política do governo veio dar respaldo à atuação de órgãos governamentais e agências públicas de fomento e financiamento no apoio a sistemas ou arranjos produtivos locais, os chamados APLs, que há alguns anos vêm sendo objeto de 
inúmeros programas e medidas, tanto no âmbito federal como nas esferas de governos estaduais, agências e bancos regionais de desenvolvimento, federações industriais, instituições paraestatais, como o Serviço Brasileiro de Apoio às Micro e Pequenas Empresas - SEBRAE e organizações não governamentais. As estratégias da PITCE estabelecem que, na dimensão regional, deviam ser privilegiados os APLs, do Plano Plurianual - PPA $^{29}$ 2004-2007 (Ministério do Planejamento, 2004) (SUZIGAN; FURTADO 2006).

De cunho essencialmente econômico e presente de modo sentido no Brasil, o debate sobre política industrial aponta para a valorização do desenvolvimento de arranjos produtivos locais, supondo que possam ter efeitos positivos no aumento da produção, da qualidade dos produtos, de seu valor agregado, da exportação e do desenvolvimento do mercado interno.

Existe uma vasta literatura nacional e internacional sobre o fenômeno da aglomeração de empreendimentos de uma mesma atividade produtiva em uma determinada região geográfica, sendo que o mesmo fenômeno é, por vezes, denominado de sistema produtivo local ou cluster $^{30}$. A opção de utilizar o termo arranjo produtivo local nesse termo de referência decorre da ampla difusão da expressão no Brasil.

Entre tantas denominações e ênfases, um dos significados atribuídos ao APL reza que são aglomerações de empresas e/ou empreendimentos, localizados em um mesmo território que apresenta especialização produtiva e mantém vínculos de articulação, interação, cooperação e aprendizagem entre si e com outros atores locais,

\footnotetext{
${ }^{29}$ O Plano Plurianual (PPA) é um instrumento previsto no art. 165 da Constituição Federal destinado a organizar e viabilizar a ação pública, com vistas a cumprir os fundamentos e os objetivos da República. Por meio dele, é declarado o conjunto das políticas públicas do governo para um período de 4 anos e os caminhos trilhados para viabilizar as metas previstas. O PPA define as políticas públicas do Governo Federal para construir um Brasil melhor, com base nos compromissos firmados na eleição. A Presidência da República tem importante função na coordenação política para a formulação do plano e o Ministério do Planejamento (MP) na coordenação técnica das funções de planejamento, orçamento e gestão. Nesse contexto, a Presidência da República, em conjunto com o MP e demais órgãos do Poder Executivo, orienta e coordena a gestão estratégica do processo de planejamento (MP, 2004).

${ }^{30}$ Um cluster, no mundo da indústria, é uma concentração de empresas que se comunicam por possuírem características semelhantes e coabitarem no mesmo local. Elas colaboram entre si e, assim, se tornam mais eficientes.
} 
tais como o governo, associações empresariais, instituições de crédito, ensino e pesquisa (CASSIOLATO; LASTRES, 2003, p. 27).

A Rede de Pesquisa em Sistemas Produtivos e Inovativos Locais (REDESIST), com sede no Instituto de Economia da Universidade Federal do Rio de Janeiro, argumenta que os APL são aglomerações territoriais de agentes econômicos, políticos e sociais com foco em um conjunto específico de atividades econômicas que apresentam vínculos, mesmo que incipientes, e geralmente envolvem a participação e a interação de empresas, que podem ser desde produtoras de bens e serviços finais até fornecedoras de insumos e equipamentos; prestadoras de consultoria e serviços; comercializadoras; clientes, entre outros e suas variadas formas de representação e associação. Incluem também diversas outras instituições públicas e privadas voltadas para a formação e a capacitação de recursos humanos, como escolas técnicas e universidades; pesquisa, desenvolvimento e engenharia; política, promoção e financiamento (REDESIST, 2003).

Em linhas gerais, um APL se caracteriza por um número significativo de empreendimentos e de indivíduos que atuam em torno de uma atividade produtiva predominante e compartilham formas percebidas de cooperação com algum mecanismo de governança; pode incluir pequenas, médias e grandes empresas. Essa definição é talvez a mais usual na formulação de políticas públicas.

Conforme salienta Suzigan e Furtado (2006), quanto aos anseios da política de apoio industrial regional:

A forma de atuação para promover o desenvolvimento regional é absolutamente relevante e corresponde aos anseios de políticos, empresários e outros atores locais ou regionais. Mas é preciso levar em conta que o apoio a APLs não é panaceia, não vai resolver todos os problemas. A promoção do desenvolvimento econômico e social das regiões depende de ações em muitas outras áreas, como as próprias estratégias e programas do PPA reconhecem. Ademais, a política regional não deve se resumir a medidas de apoio a APLs pela simples razão de que muitas atividades econômicas não se organizam territorialmente nesse formato. Portanto, é preciso manter a atuação em apoio a APLs na perspectiva adequada de modo a não gerar expectativas desmedidas ou irreais.

No Rio Grande do Sul, a história da evolução institucional de apoio aos APLs remonta aos anos de 1990, tanto que em 1999 o Governo do Estado através de sua 
Secretaria do Desenvolvimento e dos Assuntos Internacionais (SEDAI) criou o Programa de Apoio aos Sistemas Locais de Produção, que iniciou e formalizou a política voltada para APLs. Mesmo antes de 1999, já havia no RS uma política de desenvolvimento local calcada nos Conselhos Regionais de Desenvolvimento (Coredes). Desde então os diferentes governos gaúchos vêm apoiando diversas aglomerações produtivas. Tal apoio, no entanto, não foi idêntico nem teve a mesma ênfase ao longo do tempo, pois a política segmentou-se em três fases, que são coincidentes aos períodos de três governos de partidos distintos. A fase inicial (19992002); a segunda fase (2003-2006) e, a atual, a partir de 2007 (TATSCH et al., 2010, p. $55)$.

No RS, o Ministério da Integração Nacional, por meio das Secretarias de Programas Regionais, a partir de 2003, selecionou projetos nas seguintes áreas: agricultura familiar, florestamento, fruticultura, gemas e joias, leite e derivados, madeira e móveis, piscicultura, sementes orgânicas e vitivinicultura na Mesorregião Metade Sul do RS; e agroindústria, fruticultura, suinocultura, leite e derivados, piscicultura, gemas e joias e turismo na Mesorregião Grande Fronteira do MERCOSUL. Finalmente, chegouse ao âmbito privado, representado basicamente pelo Serviço Brasileiro de Apoio às Micro e Pequenas Empresas (SEBRAE), que em 2002 passou a ter prioridade sobre os APLs.

A partir das características da indústria do Rio Grande do Sul, principalmente no que se refere à concentração regional de cadeias produtivas, assim como a existência de uma rede de instituições de ensino e pesquisa e de outras instituições, o Governo selecionou cinco aglomerações na primeira fase de suas ações, as quais eram: Autopeças da região da Serra; Máquinas e Implementos Agrícolas das regiões Fronteira Noroeste, Alto Jacuí, Missões, Noroeste Colonial e Produção; Coureiro-calçadista das regiões do Vale dos Sinos e Paranhana; Moveleira da região da Serra; e Conservas e Doces Coloniais da microrregião Sul.

$\mathrm{Na}$ segunda fase, novos arranjos foram selecionados, além dos já atendidos na primeira fase, quais sejam: Gemas e joias (Vale do Taquari, Alto da Serra do Botucaraí, Médio Alto Uruguai, Serra e Fronteira Oeste), Vitivinícola (Serra), Base florestal (Metade Sul do Estado), Bioenergia e Alta Tecnologia (Metropolitana Delta do Jacuí e Vale do Rio dos Sinos).

$\mathrm{Na}$ terceira fase, somam-se ao elenco de APLs apoiados pela SEDAI, os seguintes arranjos: Têxtil e Confecções (Serra Gaúcha), Carne do Pampa (Campanha e 
Fronteira Oeste), Ovinocultura de Corte (Campanha e Fronteira Oeste), Automação e Controle Eletroeletrônico (eixo Porto Alegre - Caxias do Sul) e Polo Naval (Rio Grande).

Existe uma base potencial de mais de 30 APLs mapeados e apoiados. A diversificação dos segmentos econômicos mapeados e apoiados só se deu mais adiante, sob a influência de organismos federais e inclusive do SEBRAE (nacional-regional, respectivamente) (Tabela 4.6.1).

Tabela 4.6.1. RS: arranjos produtivos locais identificados e apoiados no RS.

\begin{tabular}{|c|c|c|}
\hline APL & MUNICIPIO & INSTITUIÇÃO* \\
\hline 1- Metalmecânico/autopeças & Caxias do Sul & Sedai \\
\hline 2 - Máquinas e implem. agrícolas/pré-colheita & Passo Fundo & Sedai \\
\hline 3 - Máquinas e implem. agrícolas/colheita & Santa Rosa & Sedai \\
\hline 4 - Máquinas e implem. agrícolas/pós-colheita & Panambi & Sedai \\
\hline 5 - Moveleiro - Serra & Bento Gonçalves & Sedai \\
\hline 6 - Moveleiro - Hortênsias e C. de Cima da Serra & Gramado & Sedai \\
\hline 7 - Moveleiro - Central & Santa Maria & Sedai \\
\hline 8 - Coureiro-calçadista & Novo Hamburgo & Sedai \\
\hline 9 - Têxtil e confecções - Hortênsias e C. de C. da Serra & Nova Petrópolis & Sedai \\
\hline 10 - Têxtil e confecções - Serra & Farroupilha & Sedai \\
\hline 11 - Gemas e jóias - Médio e Alto Uruguai & Ametista do Sul & Sedai \\
\hline 12 - Gemas e jóias - Alto Jacuí & Salto do Jacuí & Sedai \\
\hline 13 - Gemas e joias - Central & São Martinho da Serra & Sedai \\
\hline 14 - Gemas e joias - Fronteira Oeste & Quaraí & Sedai \\
\hline 15 - Gemas e joias/ extração e benef. e artef. Pedra & Soledade & Sedai \\
\hline 16 - Gemas e joias - joias folhadas e bijuterias & Guaporé & Sebrae \\
\hline 17 - Vitivinicultura - Serra & Bento Gonçalves & Sedai \\
\hline 18 - Vitivinicultura - Fronteira Oeste & Santana do Livramento & MI \\
\hline 19 - Fruticultura - Serra & Caxias do Sul & Sebrae \\
\hline 20 - Carnes/bovinocultura de corte & Bagé & Sebrae \\
\hline 21- Ovinocultura de cortes & Alegrete & Sebrae \\
\hline 22- Doces e conserva & Pelotas & Sedai \\
\hline 23- Fruticultura-Serra & Pelotas & Sebrae \\
\hline 24- Polo naval & Rio Grande & Sedai \\
\hline 25- Cachaça e derivado de cana & Santo Antônio da Patrulha & Sebrae \\
\hline 26- Leite e derivados & Passo Fundo & Sebrae \\
\hline 27- Psicultura - Fronteira Mercosul & Ajuricaba & MI \\
\hline 28- Psicultura - Metade Sul & Cachoeira do Sul & MI \\
\hline 29- Florestamento & São Sepé & MI \\
\hline 30- Flores e plantas ornamentais & Pareci Novo & Sebrae \\
\hline 31- Turismo - Serra & Bento Gonçalves & Sebrae \\
\hline 32- Turismo - Missões & São Miguel das Missões & MI \\
\hline 33- Automação e controle eletroeletrônico & Porto Alegre & Sedai \\
\hline
\end{tabular}

* Instituição = principal instituição apoiadora do arranjo.

Fonte: TATSCH, 2010. 
A formação de arranjos produtivos locais encontra-se geralmente associada a trajetórias históricas de construção de identidades e de formação de vínculos territoriais (regionais e locais), a partir de uma base social, cultural, política e econômica comum. São mais propícios a se desenvolverem em ambientes favoráveis à interação, cooperação e confiança entre os atores. A ação de políticas tanto públicas como privadas pode contribuir para fomentar e estimular tais processos históricos de longo prazo.

Por meio do Projeto Extensão Produtiva e Inovação, existem 16 Núcleos de Extensão, constituídos em parceria com universidades locais para o atendimento às empresas (Figuras 4.6.1 e 4.6.2). Na Região Fronteira Noroeste existe um conjunto importante de arranjos produtivos já estruturados como os de máquinas e implementos agrícolas, leiteiro e o moveleiro, além de potencialidade de desenvolvimento do setor de hortifrutigranjeiros, turismo e agroenergia. 


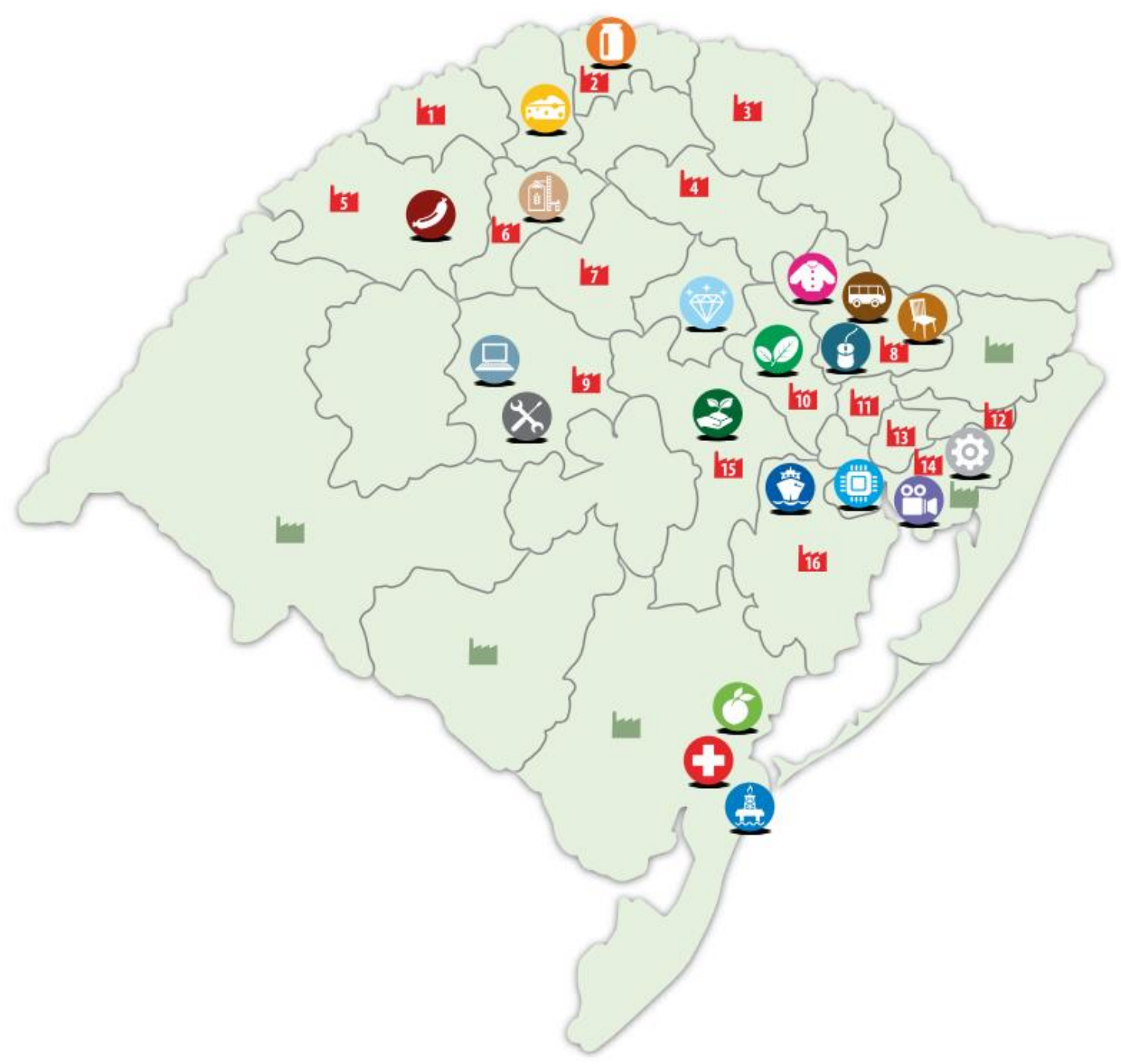

Figura 4.6.1. Núcleos de Extensão Produtivos - símbolo de indústria na cor vermelha.

Fonte: Agência Gaúcha de Desenvolvimento e Promoção do Investimento (AGDI), 2014. 


\section{Núcleos de Extensão em atividade}

\begin{tabular}{|c|c|c|}
\hline K11 & Frontelra Noroeste Celeiro & Unlversidade Reglonal do Noroeste do RS (UNUUI)-Santa Rosa \\
\hline 2 & Médio Alto Urugual & Unlv. Reg. Integr. do Alto Unuguale das Mlssöes (URI)- Frederico Westphalen \\
\hline 31 & Norte & Unlv. Reg. Integr. do Alto Unuguale das Mlssöes (URI) - Erechlm \\
\hline 14 & $\begin{array}{l}\text { Produção, Alto da Serra } \\
\text { do Botucarale Nordeste }\end{array}$ & Universidade de Passo Fundo (UPF)-Passo Fundo \\
\hline 151 & Mlssões & Unlv. Reg. Integr. do Alto Unuguale das Missōes (URI) - Santo Ångelo \\
\hline 161 & Noroeste Colonial & Universidade Reglonal do Noroeste do RS (UNIUUI)- IJuf \\
\hline 51 & Alto Jaaul & Unkversldade de CruzAlta(UNICRUZ) - Cruz Alta \\
\hline 81 & Sena & Universidade de Caxias do Sul(UCS) - Caxias do Sul \\
\hline 61 & Centrale Jacuicentro & Centro Universitário Frandscano(UNIFRA)-Santa Marla \\
\hline 1010 & Vale do Taquart & Universidade do Vale do Taquari(UNIVATES) - Lajeado \\
\hline k11 & Vale do Cal & Unlversidade de Santa Cruz do Sul(UNISC)-Montenegro \\
\hline 151 & Paranhana- Encosta da Sema e Litoral & Faculdades Integradas de Taquara (FACCAT) - Taquara \\
\hline (13) & Vale dos Sinos & Universidade Feevale-Novo Hamburgo \\
\hline 14 & Metropolitano & Centro Universitário La Salle (UNILASALLE)-Canoas \\
\hline 151 & Vale do Rio Pardo & Universidade de Santa Cruz do Sul(UNISC)-Santa Cruzdo Sul \\
\hline 16 & Centro-Sul & Universidade Luterana do Brasil (ULBRA)-São Jerônlmo \\
\hline
\end{tabular}

\section{Núcleos de Extensão previstos}

Figura 4.6.2. Núcleos de extensão em funcionamento representado pelo ícone de indústria, na cor vermelha e os previstos, na cor verde.

Fonte: Agência Gaúcha de Desenvolvimento e Promoção do Investimento (AGDI), 2014.

A competitividade entre as empresas metalmecânicas, inseridas na cadeia de fabricação de máquinas e equipamentos agrícolas estrategicamente, apontou para a necessidade de novos arranjos empresariais produtivos. É destacada a acumulação de novas competências tecnológicas dentro das fábricas, como os relacionados aos produtos, equipamentos, processos organizacionais e externamente, via articulação das empresas fornecedoras sistemistas ${ }^{31}$ e a organização de arranjo produtivo local entre as

${ }^{31}$ Um fornecedor sistemista é uma empresa instalada dentro do condomínio industrial que divide os custos de infraestrutura, transporte, saúde, alimentação entre outros serviços; possui um relacionamento estreito com a empresa focal e é responsável pela industrialização de um importante sistema do bem a ser produzido (PEREIRA et. al., 2010). 
empresas participantes desse segmento produtivo. Como resultado é constituído o APL Colheita, formado hoje por mais de 40 empresas, com destaque às de Santa Rosa e Horizontina onde ficam as bases da AGCO e da John Deere na Região.

Buttembender (2005; 2010) salienta que o principal objetivo do APL Colheita é promover o desenvolvimento do setor metalmecânico, estimular a criação de novos postos de trabalho, a geração e distribuição de renda e o desenvolvimento econômico e social, criando e consolidando um diferencial competitivo e uma identidade regional que seja referência em colheita. A implementação desse APL visou aperfeiçoar a eficácia da infraestrutura técnica, tecnológica, produtiva e de suporte ao setor e estabelecer e aprofundar relações de cooperação entre os agentes (BUTTEMBENDER, 2007). O autor defende ainda que o "APL Colheita" pode ser considerado o maior arranjo produtivo do segmento industrial metalmecânico. Mais de $60 \%$ das colheitadeiras fabricadas no País são originadas de empresas situadas nessa região, que, com o avanço de tecnologia, foram sistematicamente transformadas em montadoras de máquinas agrícolas (BUTTEMBENDER, 2010, pp. 78- 80).

Como forma de estimular a economia no setor industrial, o Estado do Rio Grande do Sul desenvolveu políticas, programas e ações específicas de incentivo à ciência, inovação e tecnologia criando os polos tecnológicos que são ambientes propícios ao desenvolvimento tecnológico, dotados de infraestrutura adequada, trabalhando com programas que estimulam a sinergia entre poder público, meio empresarial e acadêmico. Esses ambientes podem se constituir em incubadoras e condomínios de empresas de base tecnológica.

Existem mais de vinte polos tecnológicos já institucionalizados no RS (Figura 4.6.3). O Programa de Apoio aos Polos Tecnológicos foi criado pela Secretaria da Ciência Inovação e Desenvolvimento Tecnológico (SCIT) em 1989 para estimular a integração entre universidades e centros de pesquisa com o setor produtivo, objetivando o desenvolvimento de tecnologias adequadas às diferentes regiões do Estado. 


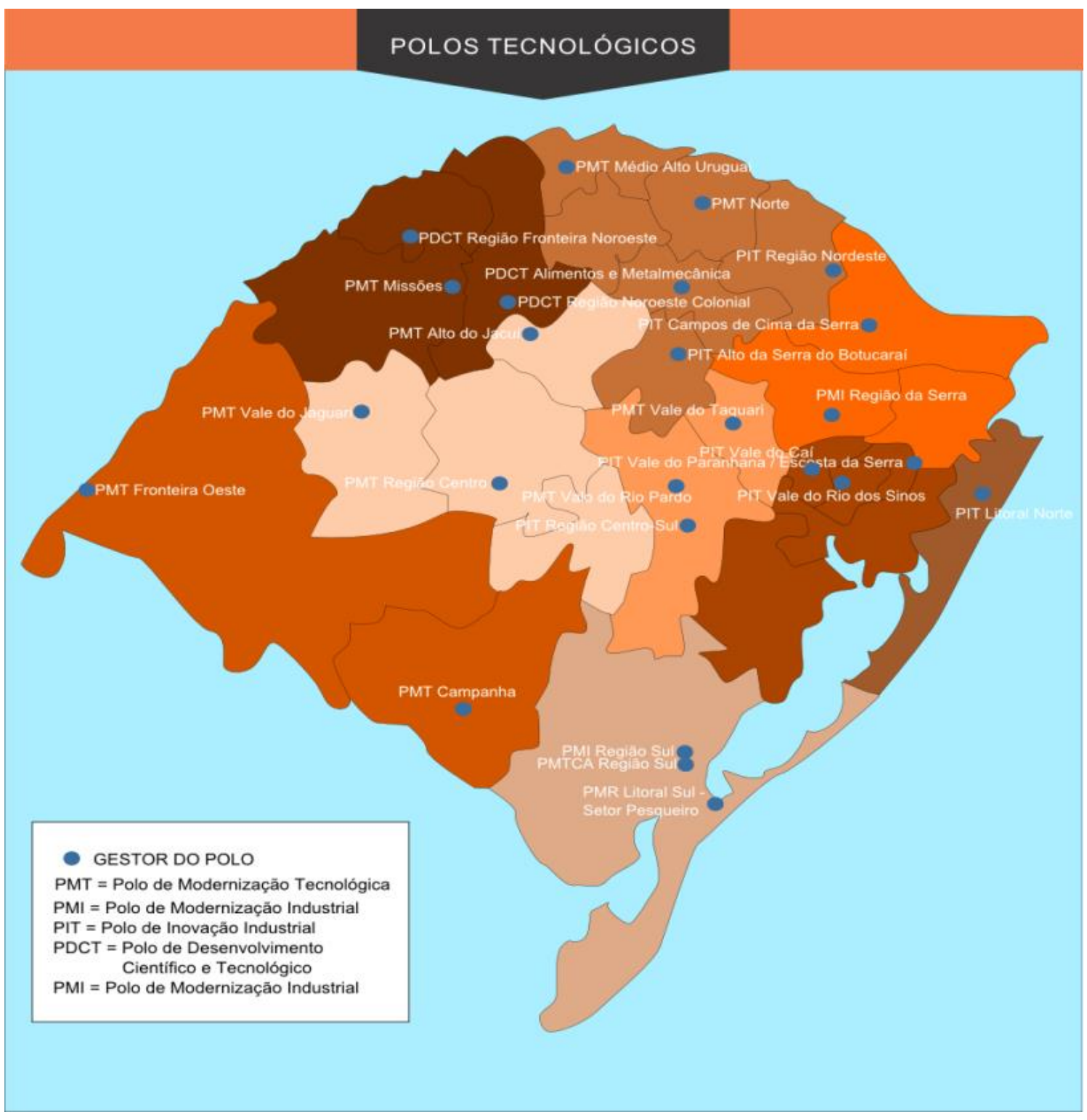

Figura 4.6.3. Polos tecnológicos instalados no Rio Grande do Sul.

Fonte: Sala do Investidor, 2013.

O programa fornece apoio financeiro a projetos de pesquisa aplicada junto a 26 Polos Tecnológicos, em 23 regiões do Estado, que abrangem um total de 456 municípios (Figura 4.6.3). Em 2011, a SCIT contemplou 39 projetos, com recursos na ordem de R \$ 5,2 milhões, impactando diversas regiões do Estado.

O Polo de Desenvolvimento Científico e Tecnológico da Região Fronteira Noroeste foi criado no ano de 1998 atuando nos segmentos metalmecânico, tecnologia de alimentos e construção civil, apoiado pela Universidade Regional do Noroeste do Estado do RS - UNIJUÍ. 


\subsection{SINDICATOS DOS SEGMENTOS ALIMENTAR E METALMECÂNICO}

Em Santa Rosa estão presentes vários sindicatos representativos da classe trabalhadora e patronal nos diversos ramos dos setores primário, secundário e terciário. Os sindicatos foram organizados com a mobilização de uma parcela de trabalhadores e empresários regionais para atendimento de seus interesses comuns. Em consonância com os sindicatos, em Santa Rosa e nos municípios próximos, existe uma gama considerável de empresas que contemplam quase todos os segmentos econômicos do conjunto da sociedade, com destaque principalmente para a indústria alimentar e metalmecânica, presentes em maior número no município objeto desse estudo.

Os sindicatos representativos dos segmentos alimentício e metalúrgico tanto da classe dos trabalhadores como da patronal estão presentes representando vários municípios que compõem a região.

O sindicato dos empregados das indústrias de alimentos se faz presente em Santa Rosa abrangendo uma área com mais de 20 municípios da região Fronteira Noroeste e outros bem próximos à região (Alecrim, Alegria, Boa Vista do Buricá, Campina das Missões, Cândido Godoi, Dr. Maurício Cardoso, Giruá, Horizontina, Independência, Nova Candelária, Novo Machado, Porto Lucena, Porto Mauá, Porto Vera Cruz, Porto Xavier, Santo Cristo, São José do Inhacorá, Santa Rosa, São Martinho, São Paulo das Missões, Senador Salgado Filho, Três de Maio, Tucunduva e Tuparendi). De um universo de mais de 3.000 trabalhadores 1.100 são associados ao sindicato, lotados em mais de 200 empresas.

Ao sindicato da alimentação estão conveniados os segmentos industriais de produtos cárneos, conservas de frutas e legumes e outros vegetais, de óleos vegetais: bruto e refinado, de laticínios, preparação do leite, sorvete, de farinha de trigo, milho e mandioca e seus derivados, moagem de café, alimentos e pratos prontos, massas alimentícias, especiarias, beneficiamento de arroz, de vinho, de malte, águas envasadas, refrigerantes, produtos de fumo, de biscoitos e bolachas, moagem de trigo e fábrica de derivados, erva-mate, abate de reses, abate de suínos, dentre outras (Sindicato dos Trabalhadores da Indústria de Alimentos, 2014). Destaque para algumas das principais indústrias como o Frigorífico Aliben, a Indústria Ervateira Vier, BRFoods, Camera, Cooperativas Agrícolas.

O Sindicato das Indústrias Metalúrgicas Mecânicas e de Material Elétrico de Santa Rosa - SIMMMESR (Figura 4.7.1) é fruto da mobilização de um grupo de 
empresários do segmento metalúrgico mecânico. A transformação da associação em sindicato foi deliberada pela Assembleia Geral realizada no dia 05 de agosto de 1985, com participação de 83 empresas, distribuídas nos municípios de Santa Rosa, Giruá, Três de Maio, Horizontina, Tucunduva, Tuparendi e Santo Cristo, que também aprovaram a extensão da base territorial do sindicato para esses municípios. Atualmente, a esse sindicato patronal estão associadas mais de trezentas empresas do ramo metalúrgico e, desse universo, cerca de trinta delas mais se destacam como fornecedoras sistemistas de peças e componentes para grandes montadoras de automotrizes e tratores na região e também de implementos agrícolas. Salientam-se algumas como a Metalúrgica Fratelli, Jama, Chapeamec, Flores, Enwall, Metal Star, Mega, Metal K, Netz (Figura 4.7.2), Vargas, dentre outras.

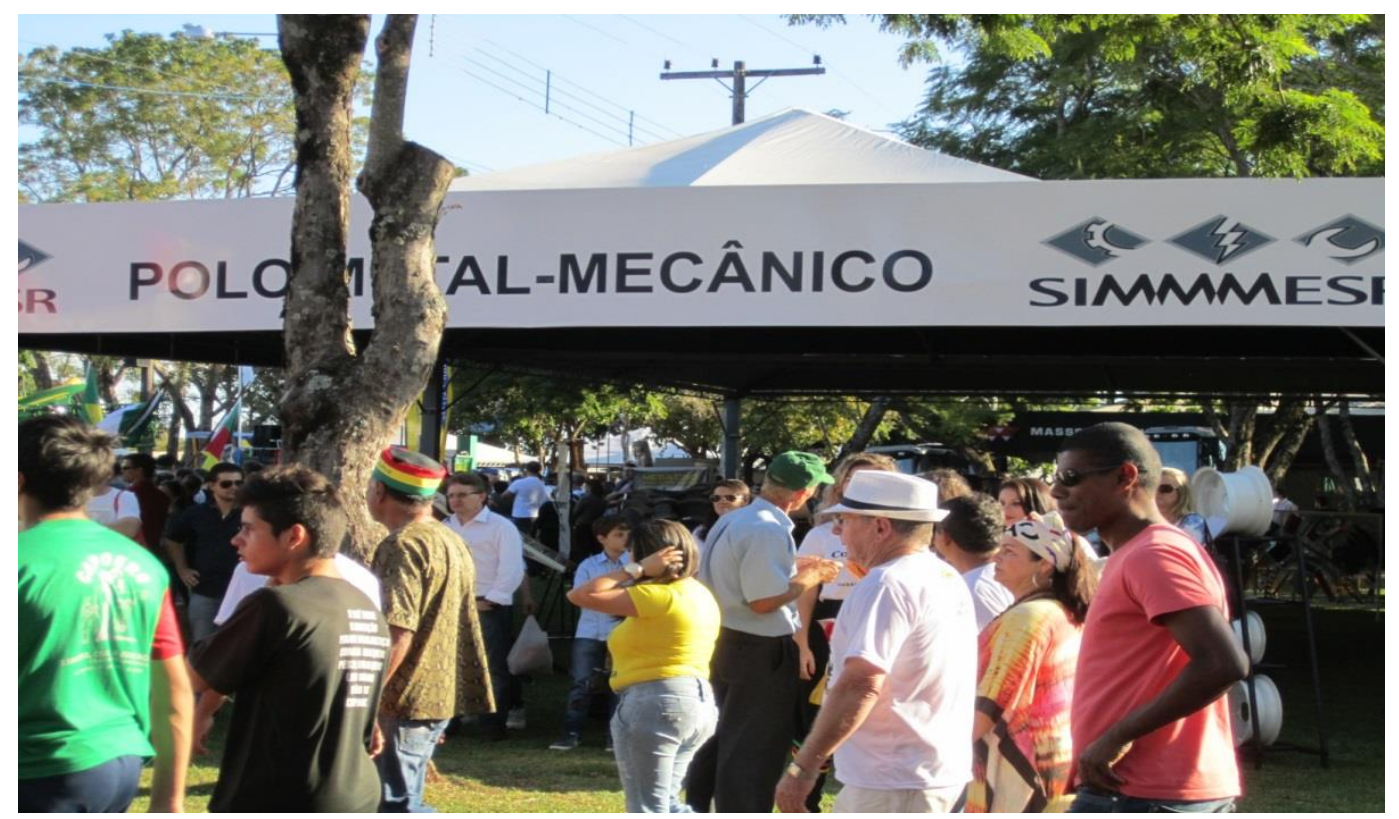

Figura 4.7.1. Sindicato das Indústrias Metalmecânicas e de Material Elétrico de Santa Rosa - SIMMMERS (Patronal).

Fonte: $\mathrm{O}$ autor 


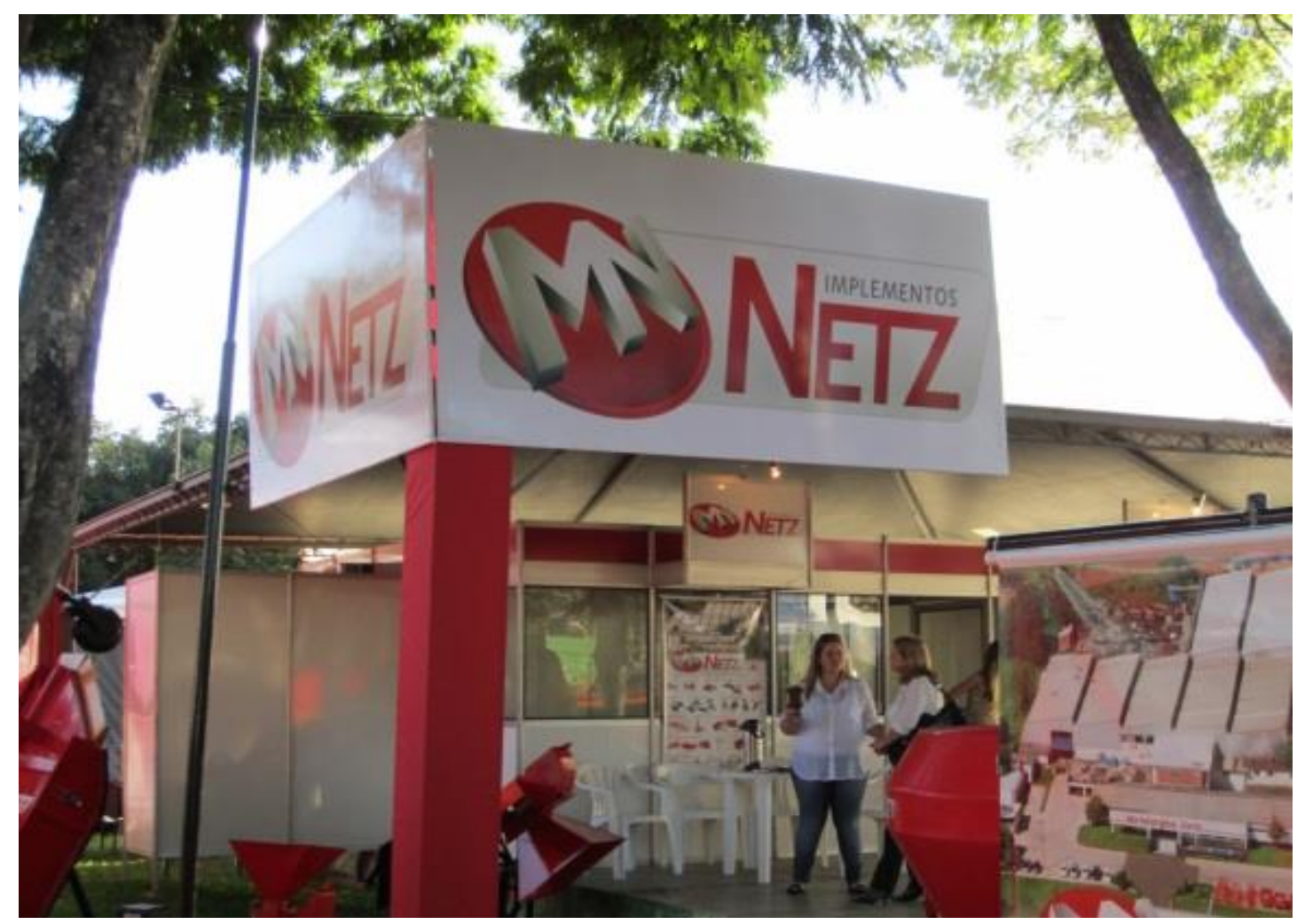

Figuras 4.7.2 Netz Implementos Agrícolas, indústria metalmecânica de Santa Rosa. Fonte: $\mathrm{O}$ autor.

Por outro lado, está presente em Santa Rosa o sindicato representativo da classe trabalhadora do segmento metalúrgico mecânico desde 1978 e atualmente está representado administrativamente pelo Sr. Janir Lino, seu presidente. Conta com cerca de dois mil associados (Figura 4.7.3) num universo de mais de 3.500 trabalhadores distribuídos em mais de 500 empresas na base (Figura 4.7.4), composto pelos municípios de Santa Rosa, Santo Cristo, Alecrim, Giruá, Cândido Godói, Campina das Missões, São Paulo das Missões, Porto Lucena, Porto Xavier e Tuparandi (Sindicato dos Metalúrgicos de Santa Rosa, 2013). 
Número aproximado de trabalhadores associados aos Sindicatos da Alimentação e Metalmecânica

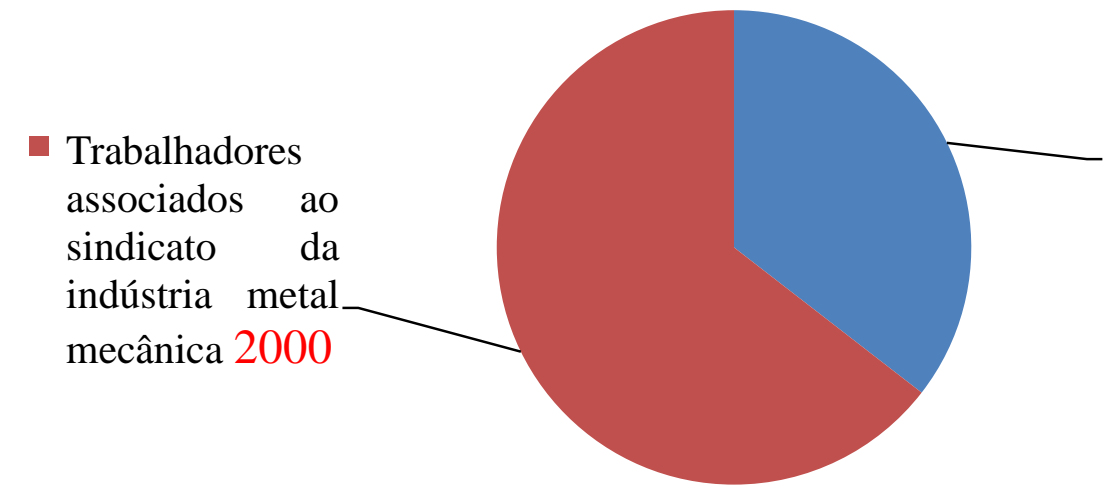

Trabalhadores associados ao sindicato da indústria alimentar 1.100

Figura 4.7.3. Número aproximado de trabalhadores associados ao sindicato dos trabalhadores da indústria alimentar e metalmecânica.

Fonte: Sindicato dos empregados da alimentação e metalúrgico de Santa Rosa, 2014.

Número aproximado de Indústrias Alimentares e Metalmecânicas no Corede Fronteira Noroeste, em 2014

Indústria Metalmecânica - 500 em 2014

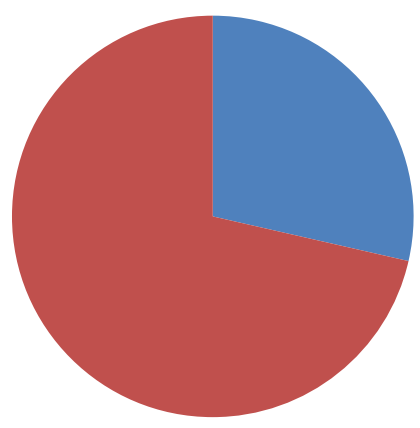

Indústria

Alimentar - 200

em 2014

Figura 4.7.4. Número aproximado de empresas do segmento alimentar e metalmecânico na microrregião Corede Fronteira Noroeste.

Fontes: Sindicato dos empregados da alimentação e metalúrgico de Santa Rosa, 2014.

A maioria dos associados está lotada nas empresas fornecedoras sistemistas, outros tantos, nas produtoras de máquinas e implementos agrícolas e de peças componentes de tratores e montadoras de automotrizes. Esse sindicato atua em várias frentes buscando uma solução junto às empresas do ramo nas questões de negociação salarial, horas despendidas ao trabalho e férias. Também atua buscando atender os 
associados na busca por serviços médicos, áreas de lazer, serviços advocatícios, dentre outros benefícios. A região representada pelo Sindicato é uma das precursoras no Estado do RS na conquista da redução da jornada de trabalho para 40 horas semanais sem haver redução de salários.

Percebe-se que no universo econômico a absorção de trabalhadores na indústria alimentar e metalmecânica é bastante significativa para Santa Rosa e demais municípios na microrregião, bem como se constata que existem muitos estabelecimentos cujos trabalhadores estão associados aos sindicatos representativos desses dois segmentos industriais. Também é possível afirmar que houve incremento de trabalhadores na indústria metalmecânica do município e região, a partir de dos anos de 1990. A mesma situação é verificada quando se trata da indústria alimentar, embora o segmento tenha se cristalizado, ancorado em torno de algumas grandes empresas: a Alibem (embutidos suínos), BRFoods (laticínia), Ervateira Vier (erva-mate), Camera (óleos e farelos vegetais).

Pode-se argumentar que as indústrias que transformam e beneficiam a produção agrícola e pecuária aumentaram o número de estabelecimentos nos últimos tempos, tais como as microempresas panificadoras, as produtoras de alimentos prontos (massas, biscoitos, comida congelada) e os pequenos laticínios e abatedouros, que têm gerado muitos postos de trabalho, segundo informa em 2014 o Sindicato dos Trabalhadores da Indústria Alimentar de Santa Rosa.

O mapa da Figura 4.7.5 mostra o número aproximado do pessoal ocupado na indústria produtora de alimentos em todos os municípios do Estado do Rio Grande do Sul. As áreas destaques em volume de trabalhadores das indústrias alimentícias são verificadas na Região Metropolitana de Porto Alegre e arredores, núcleos do Sul, Norte, Noroeste e Sudoeste gaúcho. Nessa última região citada, há a presença de frigoríficos, abatedouros e outras indústrias relacionadas ao beneficiamento de produtos agrícolas, como o arroz, por exemplo. 


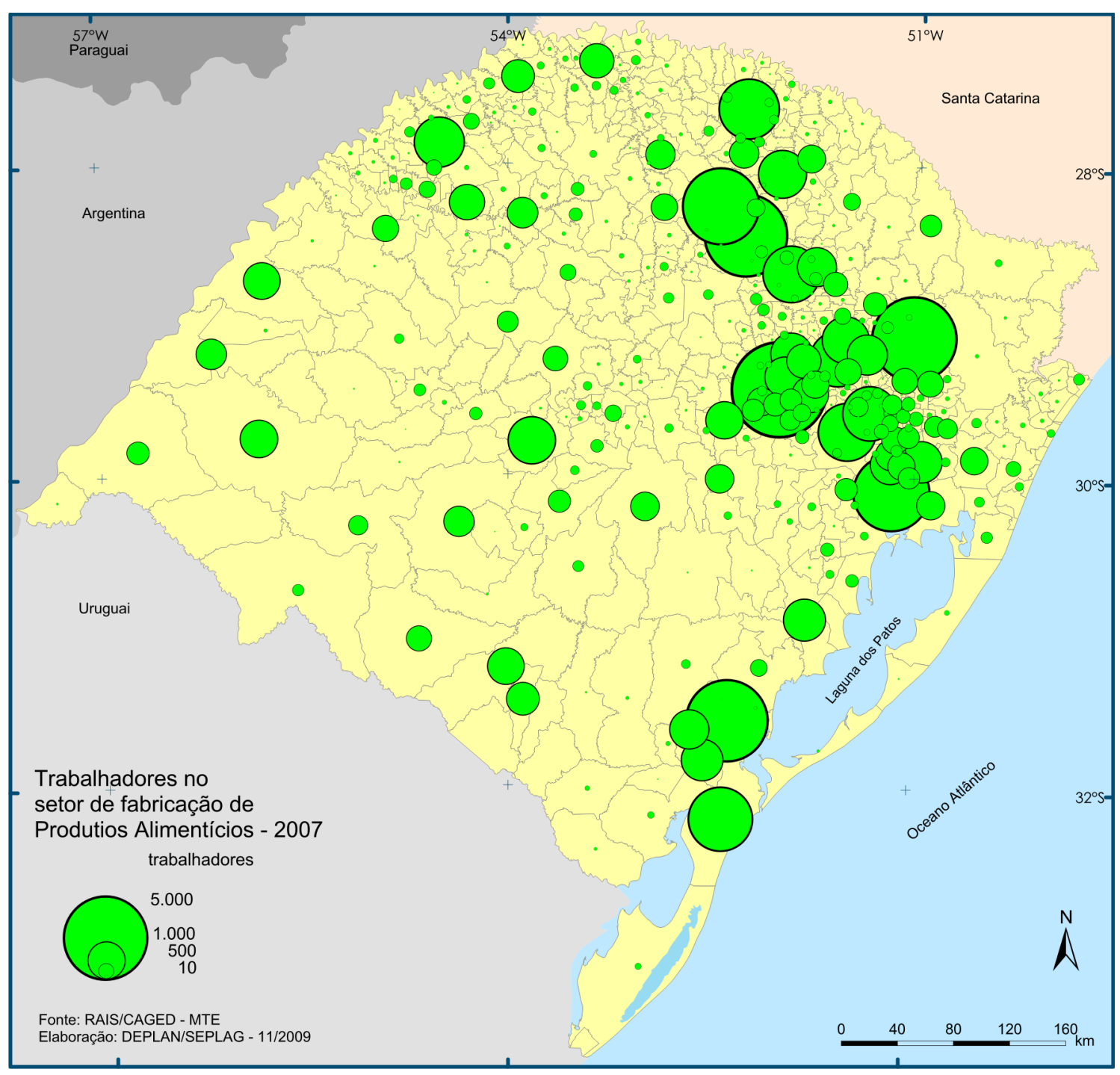

Figura 4.7.5. Número de trabalhadores na indústria de produtos alimentícios no RS.

Fonte: DEPLAN/SEPLAG, 2014.

No outro importante segmento industrial estão os trabalhadores das empresas metalmecânicas em todo Estado do Rio Grande do Sul. Pelo mapa da figura 4.7.6 verificam-se os principais polos metalmecânicos que estão localizados na Região Metropolitana de Porto Alegre e sua vasta adjacência, incluídos os polos Corede Serra, Corede Metropolitano Delta do Jacuí, Corede Vale dos Sinos, Corede Vale do Caí, Paranhana, Corede Centro-Sul e, mais ao Norte e Noroeste, os Corede Fronteira Noroeste, Corede Missões; Corede Norte e uma parcela bem inferior de trabalhadores desse segmento na porção sul do RS. 


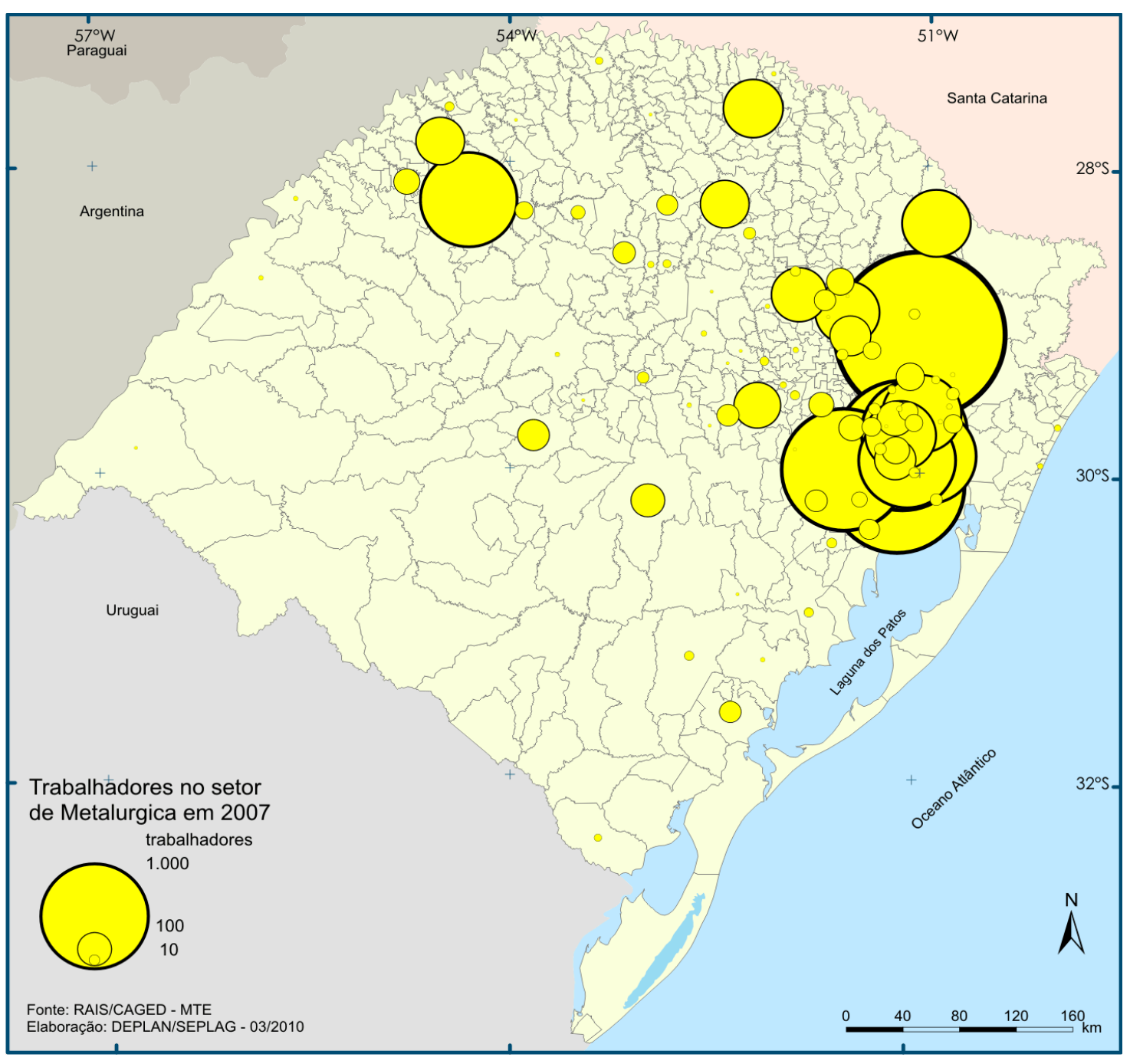

Figura 4.7.6. Trabalhadores do setor metalmecânico no RS, em 2007.

Fonte: DEPLAN/SEPLAG, 2014.

Em âmbito geral, o mapa da figura 4.7.7 atesta parte do que foi colocado ao longo deste trabalho, uma vez que ele situa os principais polos absorvedores de mão-deobra do setor secundário no Rio Grande do Sul. A partir dos anos de 1970, parcela da população regional migra àquelas áreas mais industrializadas do Estado à procura de melhores oportunidades de trabalho, principalmente às áreas da indústria coureirocalçadista situadas no Vale do Rio dos Sinos. No mapa da figura 4.7.7 são observados os polos econômicos mais e menos dinâmicos e o número de postos de trabalho como a área metropolitana de Porto Alegre e arredores, no sudeste; no norte, noroeste e sul do RS. As concentrações mais numerosas de postos de trabalho no Estado do RS também coincidem com as áreas onde se processaram os primeiros núcleos urbanos do Estado. 
No entanto, os núcleos secundários (como o Noroeste do RS) foram colonizados e dinamizados mais tardiamente, nas décadas iniciais do século passado.

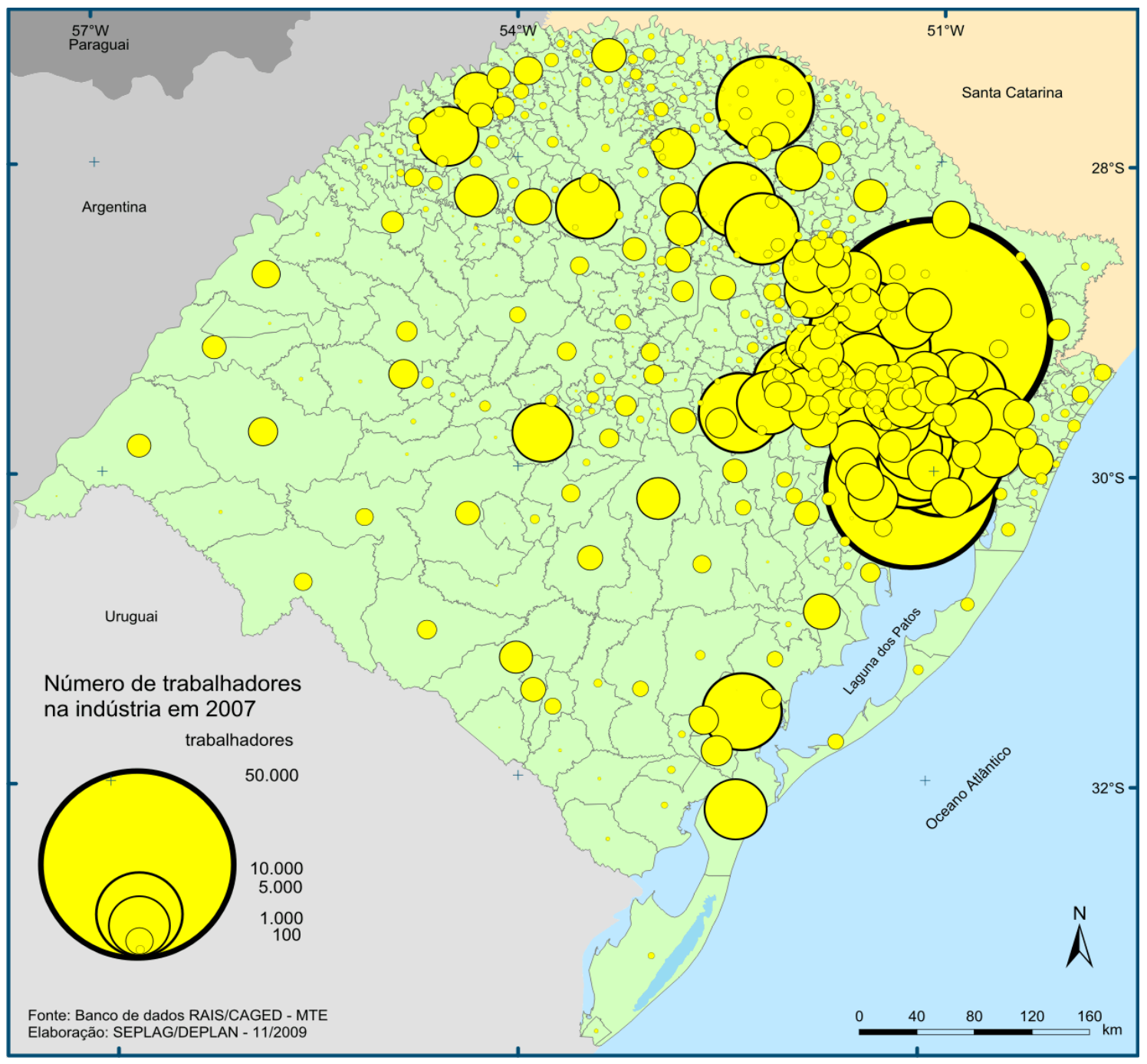

Figura 4.7.7. Número de trabalhadores da indústria do RS, em 2007.

Fonte: SEPLAG/DEPLAN, 2014. 


\section{CONSIDERACÕES FINAIS}

O esforço em promover o crescimento regional se ajustou ao pensamento que buscava a inserção competitiva de mercado a partir dos anos de 1950. A ideologia desenvolvimentista insere-se na região, vinculada ao pensamento neoliberal de competitividade, e essa inserção ocorre de modo irreversível dentro de uma estrutura fundiária regional. A região como um todo se assume como um grande centro produtor vinculado ao modelo agroexportador nacional. Seguindo o mesmo raciocínio, o Noroeste do Rio Grande do Sul correspondeu às primeiras expectativas do Governo quanto à produção da oleaginosa soja em maior escala. A partir dos anos 1960, a soja se estabeleceu como cultura economicamente importante para o Brasil.

Os segmentos da sociedade de maior influência local-regional articularam e aceitaram a introdução da modernização agrícola como a "vocação econômica regional”. E a articulação em caráter regional, pensada com base em interesses externos, deu-se, entre outros, pelo desenvolvimento de cooperativas, centros experimentais, cursos técnicos voltados à atividade agrícola e algumas empresas agroindustriais. Desse modo, pode-se aceitar que, enquanto fruto de relações das atividades capitalistas, a opção para o crescimento econômico da Região Noroeste esteve de acordo com os anseios de um período que antevia na noção de progresso o caminho para o desenvolvimento.

A opção pela modernização da agricultura e pela agroindustrialização viabilizou a formação de um conjunto de indústrias em Santa Rosa e região: por um lado, as indústrias transformadoras de produtos gerados pela agricultura regional e, por outro, as indústrias de máquinas, implementos e insumos agrícolas. Com a implementação da matriz produtiva agroexportadora surge uma nova elite local, representada por comerciantes de insumos e empresários agrícolas, ambos ligados à modernização da agropecuária. A nova elite reproduz estímulos externos, integrando-se de modo funcional à dinâmica nacional e também internacional daquele setor.

Associado ao maior desempenho agrícola assumido pela região dão-se as primeiras iniciativas agroindustriais. Em 1956, foi fundado o Frigorífico Santa-rosense, uma indústria fruto da união de mais de 100 associados. Ao mesmo tempo, a produção leiteira também se fez sentir na região, uma vez que a criação do gado vacum servia de renda de apoio ao produtor rural da época. Em 1955 surge a Laticínios Mayer que passa 
a unir esforços para o recolhimento de leite de diversos produtores dando mais dinamicidade à região. Também nos anos de 1950, despontam no cenário econômico regional os embriões que darão alicerces para a fundação das duas principais empresas montadoras de equipamento e máquinas agrícolas do Rio Grande do Sul: a Schneider Logemann S.A, de Horizontina, seguida pela Ideal Indústria de Máquinas Agrícolas, de Santa Rosa.

O número de pequenos estabelecimentos fundiários na porção noroeste gaúcha participou de um modo intenso na produção agrícola, o que a caracteriza como uma região tipicamente de minifundiários. Tida como a principal cultura agrícola, a soja alavancou a economia da região de estudo, tendo sido aumentada a sua área de cultivo e mantidos seus índices de produtividade, principalmente com a utilização de insumos como os adubos químicos, defensivos agrícolas e a tecnologia mecânica. O milho passa a perder terreno agrícola para a soja, mesmo fazendo parte da cadeia produtiva na composição alimentar do gado suíno e bovino. A produção agrícola de soja se fez presente desde os tempos em que o município de Santa Rosa era tido por "Capital Nacional da Soja" e, logo mais, por "Berço Nacional da Soja". Com o advento da "Operação Tatu” passou-se a ter a produção de grãos em maior escala, o que gerou a necessidade de armazenar a produção das lavouras da região.

Na Fronteira Noroeste do RS, verificou-se que os produtores agrícolas entregam a produção para diferentes destinos. Com as cooperativas agrícolas fica o equivalente à maior quantidade vendida, o que mostra a importância desses estabelecimentos à produção. Já as vendas para a indústria representam o segundo destino, enquanto a venda para os intermediários corresponde à menor parcela do total vendido. As cooperativas estão presentes de modo significativo e em longo tempo na região, a exemplo da Coopermil e da Cotrirosa que cobrem vários municípios. Na produção do trinômio trigo-milho-soja, o papel das cooperativas agrícolas, em caráter local, é marcante, porque elas contribuem para a arrecadação e retorno fiscal à região, como o índice de retorno do imposto sobre circulação de mercadorias e serviços, de caráter estadual.

A introdução da soja cumpriu uma função importante no desenvolvimento da região porque se aliou aos interesses de grandes empresas. Estas sempre foram as maiores beneficiadas com o processo de expansão da soja. Por outro lado, os fornecedores de máquinas e equipamentos agrícolas, óleo e farelo, as empresas de armazenamento e outros prestadores de serviços, enfim, todos os negócios dependentes 
da produção de soja são responsáveis por uma significativa participação na composição do Produto Interno Bruto da região. Chama à atenção que a composição da renda interna do município de Santa Rosa, a partir dos anos de 1960, mantém o setor primário sempre em terceiro plano, ao passo que os setores terciário e secundário em primeiro e segundo planos, respectivamente. Mesmo assim, tanto o setor secundário como o terciário muito dependem do setor primário para manterem as posições que ocupam.

Em alguns períodos de extremos climáticos que foram sentidos de forma reincidente na região, como os veranicos (as estiagens) ocorridos nas últimas três ou quatro décadas, é perfeitamente admissível reconhecer que o fenômeno meteorológico agiu de forma direta sobre o rendimento agrícola, trazendo quedas consideráveis no volume de produção de soja e milho, uma vez que o estresse hídrico prejudicou a formação, o desenvolvimento e a colheita das culturas vegetais, bem como afetou toda a cadeia produtiva, tendo prejudicado o abastecimento dos animais que necessitavam desses componentes alimentares e de pasto vegetal. O efeito econômico em "cascata" estendido entre os diversos setores da economia foi sentido pela atividade industrial e os diversos tipos de serviços. Tais setores assim como as atividades econômicas mencionadas são os pilares que dão embasamento à composição da renda dos municípios, especialmente porque os índices de retorno fiscal sofrem quedas acentuadas com o encolhimento de rendimento agrícola.

Pode-se argumentar que grande parcela das atividades atreladas ao plantio agrícola de culturas, como soja e milho, por exemplo, deu-se a partir do Estado gaúcho uma vez que o Rio Grande do Sul criou condições efetivas para desenvolver o agronegócio em diferentes escalas. Dada à necessidade de maior produção da agropecuária e já cessadas as possibilidades de expansão de produtividade em função do tamanho reduzido da maioria das propriedades fundiárias (propriedades agrícolas familiares), característica como já foi dito intrínseca ao meio rural do Noroeste desse Estado, muitos produtores passaram a migrar no decorrer de algumas décadas para outras áreas do País, implantando "novas fronteiras agrícolas" em outros biomas brasileiros, nos quais têm reproduzido os mesmos métodos utilizados no Sul. Tanto é assim que nos últimos vinte anos a produção de grãos no bioma cerrado da Região Centro-Oeste do País suplantou a produção de grãos do Rio Grande do Sul. Também partes das Regiões Norte e Nordeste do País cederam áreas para o desenvolvimento de commodities agrícolas em escala do agronegócio. 
O pequeno produtor em diferentes períodos econômicos se capitaliza e assume compromissos no sistema de crédito financeiro agrícola. Apenas parte da sociedade regional ascendia ao novo patamar da ideologia do trabalho de resultados em função do e para o mercado. A grande parcela da população rural tornou-se dispensável, devido à incapacidade relativa de gerar relações de troca. Situação semelhante pode ser a do empresário industrial que, necessitando modernizar sua instalação fabril, ingressa necessariamente no sistema financeiro oficial. Incapazes de permanecer no mercado com capitais próprios, as maiores empresas locais do segmento alimentar e do metalmecânico passaram, aos poucos, seu controle acionário aos grandes grupos multinacionais.

No Brasil muitas microrregiões possuem características comuns entre si, como o predomínio de atividades econômicas ligadas essencialmente à produção primária. A porção territorial conhecida como Noroeste do Rio Grande do Sul não foge a esse contexto, pois seu histórico econômico esteve, até meados do século passado, atrelado à produção de artigos de consumo corrente, como os da indústria alimentícia, por exemplo. Em um período recente da política econômica nacional, a partir dos anos finais de 1970, a crise produtiva obrigou grande parte das microrregiões brasileiras a buscarem soluções com vistas a combater a estagnação econômica. Dentre as soluções apontadas às diversas microrregiões que tinham como base o setor primário colocava-se a modernização da agropecuária e das indústrias a ela vinculadas, que tinha por objetivo a geração de maior valor agregado à produção, o que implicaria também na obtenção de desempenhos fiscais mais eficientes.

As dificuldades que atingiram o processo produtivo agrícola e industrial em tempos de economia inflacionária na década de 1980 exigiram soluções imediatas para reversão do quadro vigente de estagnação pela qual passava a microrregião Fronteira Noroeste do RS. O problema das desigualdades socioeconômicas torna-se então uma constante preocupação dos governantes que buscaram, através de uma política diferenciada às regiões periféricas, impulsionar o crescimento econômico e promover sua inserção no novo paradigma da economia regional, nacional e internacional.

Foram muitos os debates e as iniciativas sobre regionalização e participação da sociedade na formulação das políticas públicas no Estado gaúcho. Nesse sentido, diversos estudos técnicos produzidos ao longo de anos reconheceram regionalizações internas nesse Estado e a existência de microrregiões específicas com desiguais ritmos de desenvolvimento. Setores importantes da sociedade local e regional se mobilizaram 
para encontrar "fórmulas" capazes de modificar o andamento da economia, cujos esforços visavam manter os agricultores no campo, evitando a fuga do empresariado local e, principalmente, cessando a evasão de efetivo humano para outras regiões economicamente mais bem colocadas.

Institucionalizados pelo governo em finais de 1994, os atuais 28 Conselhos Regionais de Desenvolvimento (Coredes) hoje se encontram distribuídos entre nove regiões funcionais de planejamento. Tais agrupamentos têm confirmado seu objetivo de facilitar a regionalização de políticas e órgãos públicos e agregar microrregiões com alguma identidade comum. Esse tipo de regionalização passou a ser o mais utilizado em planejamento no Estado, tendo enfrentado, desde sua criação, vários tipos de dificuldades, por ser um tipo de regionalização que tem por base os preceitos locais, até de fato se institucionalizar e ser assumido como uma região de estudo e de referência para políticas públicas. Os Coredes conseguiram ocupar uma posição relevante no quadro institucional do Estado, podendo ser considerados hoje uma das mais bem sucedidas experiências desse gênero no Brasil.

Conforme se disse em outro momento deste estudo, o debate sobre política industrial apontou para a valorização do desenvolvimento de arranjos produtivos locais, os APLs. Levadas em contas as características da indústria do Rio Grande do Sul, principalmente a concentração regional de cadeias produtivas, e a existência de uma rede de instituições de ensino e pesquisa e de outras instituições, a criação do APL Metalmecânico rendeu para a Região Fronteira Noroeste o "APL Colheita". Mais de $60 \%$ das colheitadeiras fabricadas no Brasil vêm de empresas situadas na Fronteira Noroeste, especificamente nos municípios de Santa Rosa e Horizontina. O fato de a região comportar duas empresas de grande porte tem feito dela um polo regional atrativo porque movimenta uma soma considerável de capitais, mão-de-obra qualificada, cursos técnicos especializados para a formação e a manutenção de pessoal, além de articular várias empresas fornecedoras sistemistas.

Também como forma de estimular a economia no setor industrial, o Rio Grande do Sul dispõe de políticas, programas e ações específicas de incentivo à ciência, inovação e tecnológica, os programas de apoio aos polos tecnológicos, os quais são dotados de infraestrutura adequada, trabalhando com programas que estimulam a sincronia entre poder público, meio empresarial e acadêmico. $\mathrm{O}$ polo de desenvolvimento científico e tecnológico da microrregião Fronteira Noroeste foi criado no ano de 1998 atuando nos segmentos metalmecânico, tecnologia de alimentos e 
construção civil, apoiado pela Universidade Regional do Noroeste do Estado do RS Fidene/Unijuí. Esse tipo de iniciativa, criada pelo governo com parcerias entre o poder público, classe empresarial e os centros acadêmicos que vem acorrendo desde os anos finais dos anos de 1980, trouxe impactos significativos à microrregião, uma vez que procurou equiparar essa região com outros polos de desenvolvimento estaduais e nacionais.

É interessante lembrar que as iniciativas do governo municipal apoiadas pelos empresários da indústria, pelos trabalhadores e pela sociedade como um todo, a partir dos anos de 1980, vêm construindo as bases legais específicas para transferência de instalações fabris, denominadas de áreas e distritos industriais. Essas áreas têm cumprido um papel relevante, organizando melhor os fluxos produtivos e melhorando as condições de recebimento e depósito de matéria-prima, bem como o escoamento da produção. Além disso, têm levado para fora do perímetro urbano algumas indústrias consideradas impróprias à saúde e ao meio natural sempre que essas descumprem com a legislação ambiental estabelecida, tal quando há o descarte de minerais pesados e outros dejetos nos cursos dos rios, emissão de gases considerados nocivos e o excesso de ruídos. Há uma tendência no município de Santa Rosa em transferir determinados segmentos da indústria instalados dentro do perímetro urbano para áreas industriais específicas.

As indústrias do segmento alimentar são as pioneiras na história econômica regional, sendo que a produção de erva-mate, de grãos e a criação de animais marcam toda a trajetória econômica do município de Santa Rosa. Antes mesmo da chegada dos imigrantes europeus (alemães, italianos e poloneses) já haviam se estabelecido na região os remanescentes de origem portuguesa, os caboclos que aqui viviam e tinham na produção da erva-mate uma fonte geradora de recursos, embora ainda produzida com métodos rudimentares. Com a chegada dos imigrantes e descendentes advindos de outras áreas rio-grandenses, aliado a um aporte maior de capitais, houve um incremento na produção dos ervais e no beneficiamento da matéria-prima.

Considerando que Santa Rosa se tornou o município polo de sua microrregião ao longo do seu processo econômico, sobretudo a partir dos anos 1950, quando da implantação das maiores indústrias, representadas pelos segmentos alimentar e metalmecânico, pode-se argumentar que houve um considerável crescimento das plantas industriais desses dois segmentos ao longo de mais de cinquenta anos. Porém, o segmento alimentar, apesar de gerar muitos empregos e movimentar toda uma cadeia 
produtiva, principalmente pela produção suína e leiteira, não deu sinais de muito crescimento, estando ancorado em suas indústrias principais: a Aliben, a BRF, a Camera, a Ervateira Vier, não tendo se instalado outras grandes indústrias alimentares.

Devido à entrada de maior volume de capital, advindo da transferência do controle acionário, as empresas frigoríficas e de laticínios foram sendo progressivamente encampadas em alguns municípios da região por grupos empresariais estrangeiros. A Alibem, produtora de artigos cárneos (cortes nobres e os embutidos suínos), principal empresa do segmento industrial alimentar, passa seu controle acionário para o capital externo num momento econômico em que os antigos proprietários encontravam dificuldades de se manter no mercado devido a uma série de fatores que limitavam a expansão de mercado.

Há a necessidade de entender quais os motivos que justifiquem a cristalização de tal segmento alimentar em Santa Rosa. À primeira vista, a manutenção por mais de cinco décadas desse segmento se deve à importante produção local da matéria-prima agropecuária, especialmente da soja, do trigo, da erva-mate, do leite e do suíno. Dificilmente teriam sido implantadas e mantidas na região outras empresas alimentares que não fossem transformadoras e beneficiadoras de produtos locais, com exceção das ervateiras regionais, que têm trazido boa parte da matéria-prima de outros estados, como Santa Catarina e Paraná, onde há excedentes desse produto.

Num universo de mais de 200 estabelecimentos, as outras indústrias alimentares de Santa Rosa, em grande parte, não passam de pequenas e microempresas produtoras de derivados de farinha de trigo, abatedouros de animais, pequenos laticínios, fábricas de conservas de frutas e legumes e micro frigoríficos no circuito regional que receberam auxílio financeiro por parte de agentes econômicos locais e estaduais e aporte tecnológico, principalmente, a partir dos anos de 1980.

Não é possível afirmar, por outro lado, que a indústria metalmecânica acompanha o desenvolvimento da região de Santa Rosa desde o início de seu processo econômico. A instalação de empresas desse segmento industrial deu-se em um período posterior ao do segmento alimentar, nos anos de 1950, e se desenvolveu plenamente a partir dos anos de 1970, passando a região a concentrar essas empresas e a ser reconhecida nacional e internacionalmente como uma área polo de desenvolvimento com uso de tecnologia de ponta na produção de máquinas e implementos agrícolas. A partir dos anos de 1990, o segmento metalmecânico apresentou ainda uma reação significativa, tendo passado por processos de requalificação em toda a sua área de 
abrangência regional, seja entre diversas empresas sistemistas terceirizadas, produtoras de peças e outros componentes de engrenagem, seja pelas maiores montadoras de colheitadeiras, a John Deere de Horizontina e a AGCO de Santa Rosa, que também produzem implementos agrícolas.

De todo modo é importante salientar que o setor primário santa-rosense continua sendo a base para o desenvolvimento da indústria de transformação e beneficiamento assim como um indutor para diversos tipos de serviços. Sempre puxado pelo segmento alimentar o setor metalmecânico tem promovido uma maior instrumentalização dos produtores do campo e construído as competências para se tornar um polo do setor. Os ganhos gerados com a produção agropecuária, os segmentos industriais e os serviços mencionados neste estudo somam um montante considerável de receitas. Assim, a atividade industrial como um todo tem sido o elemento responsável pelo aumento dos índices de retornos fiscais para Santa Rosa, especialmente pelas receitas de ICMS e do Fundo de Participação dos Municípios (FPM), de cunho estadual e federal, respectivamente. Nesses termos, pode-se aceitar a tendência do município em atrair para si, pouco a pouco, um contingente considerável de profissionais de uma população economicamente ativa, vindos de outras microrregiões que, de um modo ou de outro, possam ter estagnado economicamente. 


\section{REFERÊNCIAS BIBLIOGRÁFICAS}

ABREU, M. P. O Brasil e a economia mundial (1930-1945). Rio de Janeiro: Ed. Civilização Brasileira, 1999.

AGÊNCIA GAÚCHA DE DESENVOLVIMENTO E PROMOÇÃO DO INVESTIMENTO (AGDI) Link de acesso http://www.agdi.rs.gov.br/ 04/2014.

ANDRIOLI, A. I. "Perspectivas da agroecologia na produção de soja em pequena propriedade na Fronteira Noroeste do Rio Grande do Sul”. In: Revista Espaço Acadêmico, nº 69, 2007.

ATLAS SOCIO ECONÔMICO DO RIO GRANDE DO SUL. Secretaria de Planejamento, Gestão e Participação Cidadã do Rio Grande do Sul - Economia. Link de acesso: http://www.scp.rs.gov.br/atlas/, 2013.

AZAMBUJA, B. M. O desenvolvimento urbano e a promoção fundiária e imobiliária na cidade de Ijuí - RS. Dissertação de Mestrado - UFSC: Florianópolis, 1991.

AZZONI, C. R.; FERREIRA, A. D. Competitividade regional e reconcentração industrial: o futuro das desigualdades regionais no Brasil. FEA/USP, 1986.

BAER, W. A industrialização e o desenvolvimento econômico brasileiro. $5^{\mathrm{a}}$ ed. Rio de Janeiro: Ed. Fundação Getúlio Vargas, 1983. . A economia brasileira. São Paulo: Livraria Nobel, 1996.

BANDEIRA, P. S. "Uma experiência de institucionalização de regiões no Brasil Coredes do Rio Grande do Sul”. In: Pró-RS IV, 2010.

BANDEIRA, M. D. Uma visão demográfica do Estado do Rio Grande do Sul no contexto brasileiro: análise dos principais indicadores demográficos. In: $A$ evolução social. (Três décadas de economia gaúcha, v.3). 2010. Link de acesso: http://www.fee.rs.gov.br/3-decadas/downloads/volume3/2/marilene-bandeira.pdf

BARROS, A. R. Desigualdades regionais no Brasil - Natureza, causas, origens e soluções. Rio de Janeiro: Ed. Elsevier, 2011

BATAlHA, M. O. (org.) Gestão Agroindustrial. Vol. 1, Atlas, São Paulo, 2001.

BECKER, D. "Os velhos e os novos desafios lógico-metodológicos na análise do desenvolvimento local-regional”. In: $O$ desenvolvimento regional. Eds. Edunisc e Unijuí - Santa Cruz do Sul e Ijuí, 2000.

BERLATO, M. A. As condições de precipitação pluvial no Estado do Rio Grande do Sul e os impactos das estiagens na produção agrícola. In: BERGAMASCHI, H. 
(Coord.) Agrometeorologia aplicada à irrigação. $1^{\mathrm{a}}$ ed. Porto Alegre: Ed. Universidade/UFRGS, p.11-24, 1992.

BERLATTO, M. A.; FONTANA, D. C. "Variabilidade interanual da precipitação pluvial e rendimento da soja no Estado do Rio Grande do Sul". In: Revista Brasileira de Agrometeorologia, v. 7, p. 119-125, 1999.

BERLATO, M. A; FONTANA, D. C. El Niño e La Niña - Impactos no clima, na vegetação e na agricultura do RS - Aplicações de previsões climáticas na agricultura. Porto Alegre: Ed. UFRGS, 2003.

BIELSCHOWSKY, R. "Cinquenta anos de pensamento na CEPAL - Uma resenha". In: Ricardo Bielschowsky (Org.) Cinquenta anos de pensamento na CEPAL. Rio de Janeiro, São Paulo: Ed. Record, 2000.

BOHN GASS, S. L.; VERDUM, R.; MANTELLI, J. Estrutura, processo, função e forma no setor agrário do Noroeste do Rio Grande do Sul In: Confins - Revista Franco-Brasileira de Geografia, $\mathrm{n}^{\mathrm{o}}$ 20, 2014. Link de acesso http://confins.revues.org/8879

BREITBACH, A. C. de M. Estudo sobre o conceito de região. Porto Alegre: FEE, 1988.

BRESSAN, S. J. Sindicalismo rural e sociedade: relações e história. Dissertação de Mestrado - UFRGS, Porto Alegre, 1978.

BRUM, A. O desenvolvimento econômico brasileiro. $11^{\mathrm{a}}$ ed. Petrópolis e Ijuí: Ed. Vozes e Fidene, 1991.

BRUM, A, J. Modernização da Agricultura: trigo e soja. Rio de Janeiro: Editora Vozes, 1988.

BRUM, A. L.; MÜLLER, P. K. Aspectos do agronegócio no Brasil. Ijuí: Ed. Unijui. 2008.

BRUM, A. L. et al. O agronegócio do noroeste gaúcho: evolução e alternativa. In: BUTTEMBENDER, P. L. (Org.) Estratégia, inovação e aprendizagem organizacional - Cooperação e gestão de competências para o desenvolvimento. Ijuí: Ed. Unijuí , 2008.

BRUM, A. L.; TRENNEPOHL, D.; TYBUSCH, T.; MARQUES, T. Proposição de estratégias de desenvolvimento ligadas ao agronegócio para o Corede Noroeste Colonial do Rio Grande do Sul. Ijuí: Ed. Unijuí, 2007.

BRUM, J. O agronegócio no contexto do desenvolvimento do noroeste gaúcho: alguns elementos para debate. In.: DALLABRIDA, V. R., BUTTENBENDER, P. L. 
(Org). Gestão, inovação e desenvolvimento: oportunidades e desafios para o desenvolvimento da Região Fronteira Noroeste. Santa Cruz: Edunisc, 2007.

BUTTEMBENDER, P. L. “Acumulação de competências tecnológicas e os processos de aprendizagem na indústria metal-mecânica: a experiência da AGCO indústria de Colheitadeiras". In: Cadernos Ebape. br, ed. especial, Rio de Janeiro: FGV, 2005 .

BUTTEMBENDER, P. L.; ROTTA, E.; HOFLER, C. E. O cooperativismo inserido na evolução e no desenvolvimento da Região Fronteira Noroeste. In: BUTTEMBENDER, P. L. (Org.) Cooperativismo na Região Noroeste do RS. Porto Alegre; Sescoop/RS, 2010a.

BUTTEMBENDER, P. L. et al. “Arranjo produtivo local colheita - Diagnóstico e definição de estratégias para maior competitividade em mercados nacionais e internacionais". In: BUTTEMBENDER, P. L. (Org.) Arranjos institucionais, cooperação e desenvolvimento. Ed. Unijuí, $2010 \mathrm{~b}$.

CANO, W. Ensaios sobre a formação econômica regional do Brasil. Campinas: Ed. da Unicamp, 2002.

CANO, W. Raízes da concentração industrial em São Paulo. Campinas - Instituto de Economia, Ed. da Unicamp, 1977.

CARA, C. A.; FRANÇA, F. M. Aspectos do processo de industrialização brasileira. IV EPCT, Francisco Beltrão: UNIOESTE, 2009

CARDOSO, V. Município de Santa Rosa, S/1, 1947.

CARLOS, A. F. A. Espaço-tempo na metrópole: a fragmentação da vida cotidiana. São Paulo: Ed. Contexto, 2001.

CARRION JR. F. M. O Rio Grande do Sul em busca de novos caminhos - por um projeto regional. Porto Alegre: Mercado Aberto, 1986. . RS: Política econômica \& alternativas. Porto Alegre: Ed. Mercado Aberto, 1981. . O modelo brasileiro: impasses e alternativas. Porto Alegre: Ed. Z Zheta, 1975.

CARVALHO, V. R. F. Indústria de laticínios no Rio Grande do Sul: um panorama após o movimento de fusões e aquisições. $1^{\circ}$ Encontro de Economia Gaúcha. Porto Alegre: FEE, 2005. cdn.fee.tche.br/eeg/1/mesa_10_carvalho.pdf.

CASTRO, A. B. 7 ensaios sobre a economia brasileira, Vol I, $2^{\text {a }}$ ed. Rio de Janeiro: Forense, 1972. 
CASTRO, I. E. Problemas e alternativas metodológicas para a região e para o lugar. In: SOUZA, M. A. A. et al. (Orgs.). O novo mapa do mundo-Natureza e sociedade de hoje: uma leitura geográfica, $2^{\text {a }}$ ed. São Paulo: Ed. Hucitec-Anpur, 1994.

CASSIOLATO, J. E.; LASTRES, H. M. M. O foco em arranjos produtivos e inativos locais de micro e pequenas empresas. In: LASTRES, H. M. M. et al. (Ed.). Pequena empresa: cooperação e desenvolvimento local. Rio de Janeiro: Relume Dumará, 2007.

CHRISTENSEN, T. Santa Rosa - História e Memórias (1876-2004). Porto Alegre: Ed. Palloti, 2008.

. Soja 80 anos de produção (1924-2004). 1º $2^{\circ}, 3^{\circ}$ e $4^{\circ}$ capítulos. Santa Rosa: Lucano Cultura e Marketing, 2004.

CORRÊA, R. L. Estudos sobre a rede urbana. Rio de janeiro: Bertrand Brasil, 2006.

_. Espaço, um conceito-chave da Geografia. In: CASTRO, I. E.; GOMES, P. C. C.; CORRÊA, R. L. (Orgs). Geografia: Conceitos e Temas. Rio de Janeiro: Ed. Bertrand Brasil, 1995.

.Algumas considerações sobre análise regional”. In: Revista Brasileira de Geografia. Rio de Janeiro, v 49, n ${ }^{\circ}$ 4, pp. 47-52, 1987.

. O espaço urbano. São Paulo: Ed. Ática, 1989.

. Região e organização espacial. São Paulo: Ed. Ática, 1991.

COSTA, F. R.; ROCHA, M. M. "Geografia: conceitos e paradigmas - apontamentos preliminares”. In: Rev. Geomae v. 1, n. 2 pp. 25-56, Campo Mourão, 2010.

CUNHA, G. R.; HAAS, J. C.; ASSAD, E. D. Zoneamento agrícola e época de semeadura para trigo no Rio Grande do Sul. Passo Fundo: Embrapa Trigo, 1999 http://www.academia.edu/3560665/Zoneamento_agricola_e_epoca_de_semeadu ra_para_trigo_no_Brasil_Agricultural_zoning_and_sowing_dates_for_wheat_in _Brazil.

DALLABRIDA, V. R. O desenvolvimento regional - A necessidade de novos paradigmas. Ijuí/Santa Cruz do Sul: Eds. Unijuí e Udunisc, 2000.

DAVIS, J. H.; GOLDEBERG, R. A Concept of Agribusiness. Boston: Harvard University, 1957.

DINIZ, C. C. A Nova Geografia Econômica do Brasil: Condicionantes e implicações. In: XII Fórum Nacional - Institutos de Altos Estudos, Rio de Janeiro, 2000. 
DINIZ, C. C. Global-local: interdependências e desigualdade/Notas para uma política tecnológica e industrial regionalizada no Brasil. Rio de Janeiro: BNDES/FINEP/FUJB, 2000 link de acesso: http://www.bndes.gov.br/.

DINIZ, C. C. A Dinâmica Regional Recente da Economia Brasileira e suas perspectivas. Texto para discussão $\mathrm{n}^{\circ} 375$. Rio de Janeiro: Ipea, 1995. Link de acesso: http://repositorio.ipea.gov.br/bitstream/11058/1741/1/td_0375.pdf

DINIZ, C. C. A.; CROCCO, M. A. Reestruturação econômica e impacto regional: O novo mapa da Indústria Brasileira. Nova Economia, Belo Horizonte, V. 6, n.1, 1996.

EINLOFT, C. A Crise da Economia Gaúcha. In: Vária Socioeconômica FEE. Porto Alegre, 1982.

EMATER - RS Empresa de Assistência Técnica e Extensão Rural do Estado do RS, 2012 Link de acesso http://www.emater.tche.br/site/.

EVANGELISTA, M. L. et al. A atividade leiteira como alternativa de geração e inclusão de capital social no contexto de pequenos produtores da Região Fronteira Noroeste do Rio Grande do Sul. In: III Seminário Internacional sobre o Desenvolvimento Regional, Santa Cruz, 2006.

EVANGELISTA, M. L., RAMBO, J. A. Cenários e perspectivas para arranjos produtivos locais do agronegócio da Região Fronteira Noroeste do RS. In: DALLABRIDA, V. R., BUTEMMBENDER, P. L. (Orgs.) Gestão, Inovação e Desenvolvimento. Santa Cruz do Sul: Edunisc, 2007.

FARINA, E. Q. M.; ZILBERSZTAJN, D. "Relações tecnológicas e organização dos mercados do sistema agroindustrial de alimentos". In: Cadernos de Ciência \& Tecnologia, V. 8, N.1/3, P. 9-27 Brasilia: EMBRAPA, 1991.

FAJARDO, S. A questão locacional e a Nova Geografia. v. 6, n. 1, pp. 161-168, Ambiência, Guarapuava, 2009.

FAJNZYLBER, F. Industrialização na América Latina: da "caixa-preta" ao "conjunto vazio". In: Bielschowsky, R. (Org.). Cinquenta anos de pensamento na CEPAL /Rio de janeiro, São Paulo: Ed. Record, 2000.

FARIA, T. C. A. B. et al. Região e Regionalização: uma proposta com base no conceito de acessibilidade. Link de acesso www.cedeplar.ufmg.br, 2013.

FEE. Fundação Economia e Estatística Siegfried Emanuel Heuser, 2003. Site de acesso www.fee.tche.br acessado em 08/2012; 12/2013; 05/2014. 
FERREIRA, C. M. C. Espaços, Regiões e Economia Regional. In: HADDAD, P. R. (Org). Economia regional: teorias e métodos de análise. Fortaleza, BNB. ETENE, 1989.

FIDENE. Plano diretor de desenvolvimento de Santa Rosa, RS - Documento I diagnóstico e recomendações, Ijuí: Ed. Unijuí, 1993.

FISHLOW, A. Desenvolvimento no Brasil e na América Latina: uma perspectiva histórica. São Paulo: Ed. Paz e Terra, 2004.

. Origens e consequências da substituição de importações no Brasil. In: Versiani, F.R.; Barros, José R. M. (Orgs). Formação econômica do Brasil - A experiência da industrialização. São Paulo : Ed. Saraiva, 1977.

FONSECA, P. C. D.; MOREIRA, C. S. O projeto do Governo Goulart e o II PND: um cotejo. Texto para discussão. Porto Alegre - UFRGS, 2012.

FRANTZ, T. R.; TEIXEIRA, E. B.; LAMPERT, A. L. O processo de formação de uma aliança estratégica: o caso SLC e John Deere In: Buttembender, P. L. (Org.) Estratégia, inovação e aprendizagem organizacional Cooperação e gestão de competências para o desenvolvimento. Ijuí: Ed. Unijuí, 2008.

FURTADO, C. Formação Econômica do Brasil. 34 ed. São Paulo: Companhia da Letras, 2010.

. "Estado e empresas transnacionais na industrialização periférica". In: Revista de economia política, vol. 1, nº 1, jan.-mar., 1981.

. A Economia Gaúcha e os Anos 80: uma trajetória regional no contexto da crise brasileira. Porto Alegre v.1,2 e 3, 1990.

. A Produção Gaúcha na Economia Nacional: uma análise da concorrência intercapitalista. Porto Alegre, 1983.

GEORGE, P. Geografia industrial do mundo. $7^{\mathrm{a}}$ ed. Rio de Janeiro: Ed. Bertrand Brasil, 2005.

GOMES, P. C. da C. O conceito de região e sua discussão. In: CASTRO, I. E. de; GOMES, P. C. da C.; CORRÊA, R. L. (Orgs.) Geografia: conceitos e temas, Rio de Janeiro: Ed. Bertrand Brasil, 1995.

GUIMARÃES, A. P. Quatro Séculos de Latifúndio. Rio de Janeiro: Paz e Terra, 1989.

HADDAD, P. R. (Org.) Economia Regional: teorias e métodos de análise. Banco do Nordeste: Fortaleza, 1989. 
HADDAD, P. R. "Regiões, regionalismos e desequilíbrios espaciais de desenvolvimento: algumas reflexões". In: Análise conjuntural, Porto Alegre: FEE, v. 2, n. 2, pp. 255-270, 1993.

HAESBAERT, R. Regional-global: Dilemas da região e da regionalização na Geografia Contemporânea. Rio de Janeiro: Bertrand Brasil, 2010.

HARVEY, D. Condição pós-moderna. 19ª ed. São Paulo: Ed. Loyola, 2010.

HERMANN, J. “Auge e declínio do modelo de crescimento com endividamento: o II PND e a crise da dívida externa (1974-1984)”. In: GIAMBIAGI, F. et al. (Org.). Economia brasileira contemporânea (1945-2004). Rio de Janeiro: Elsevier, 2005.

HIRSCHMAN, A. O. The Political Economy of Import-substituting Industrialization in Latin America. The Quarterly Journal of Economics, LXXXII(1):1-32, 1968.

HOFFMANN, R. et al. Administração da empresa agrícola. São Paulo: Pioneira, 1987.

HUNT, E. K.; SHERMAN, H. J. História do pensamento econômico. 13ª ed. Petrópolis: Ed. Vozes, 1977.

IANNI, O. Teorias da globalização. $3^{\text {a }}$ ed. Rio de Janeiro: Ed. Civilização Brasileira, 1996.

IBGE. Fundação Instituto Brasileiro de Geografia e Estatística, 2014. Links de acesso: http://seriesestatisticas.ibge.gov.br/series.aspx?vcodigo=ST44 http://www.cidades.ibge.gov.br/xtras/grafico_cidades.php?lang=\&codmun=431 720\&idtema=125\&search=rio-grande-do-sul|santa-rosa|produto-interno-brutodos-municipios-2011

JANK, M. S; FARINA, E. M. M. Q.; GALAN, V. B. O agrobusiness do leite no Brasil. São Paulo: Ed. Milkbizz /Pensa, 1999.

KATZ, J. A dinâmica do aprendizado tecnológico no período de substituição de importações e as recentes mudanças estruturais no setor industrial da Argentina, do Brasil e do México. In: KIM, L. e NELSON, R. (Orgs.) Tecnologia, Aprendizado e Inovação: as experiências das economias de industrialização recente. Campinas: Ed. Unicamp, 2005.

KUCHEMANN, B. A. O Minifúndio Gaúcho. UCS: Caxias do Sul, 1980.

JORNAL NOROESTE. Frigorífico Alibem. Um gigante da alimentação. Santa Rosa. Ed $\mathrm{n}^{\circ} 2.397,2014$.

LACOSTE, Y. Geografia do subdesenvolvimento. $7^{\mathrm{a}}$ ed. São Paulo: Difel, 1985. 
LASTRES, H. M. M.; CASSIOLATO, J. E. (Orgs.) Glossário de arranjos e sistemas produtivos e inovativos locais. In: Rede de Pesquisa em Sistemas Produtivos e Inovativos Locais, 2003. link de acesso www.ie.ufrj.br/redesist.

LAUSCHNER, R. Agribusiness, cooperativa e produtor rural. Ed. Unisinos, 1993.

LEFF, N. H. Política econômica e desenvolvimento no Brasil: 1947-1964 São Paulo: Perspectiva, 1977.

Dependency Rates and Savings Rates, Vol.59, American Economic Review, 886896, 1969.

LEFEBVRE, H. Marxismo. Porto Alegre: Ed. L\&PM, 2010.

LENCIONI, S. Região e Geografia. São Paulo: Ed. da Universidade de São Paulo, 1999.

_. Região e geografia. A noção de região no pensamento geográfico. In: CARLOS, A. F. A. (Org.) Novos caminhos da Geografia. São Paulo: Contexto, 1999.

LISBOA, M.; BAGOLIN, I. P. Evolução do comportamento das atividades setoriais do Rio Grande do Sul no período 1970-2000 - uma análise utilizando regionalização dos Coredes. In: PAIVA, C. (Org). Evolução das desigualdades territoriais no Rio Grande do Sul. Santa Cruz do Sul: Ed. Edunisc, 2008.

LOPES, F. O desafio da hiperinflação. Rio de Janeiro: Ed Campus, 1989.

LUCA, T. R. Indústria e trabalho na história do Brasil. São Paulo: Ed. Contexto, 2001

MACIEL, D. Democratização e manutenção da ordem na transição da Ditadura Militar à Nova República (1974-1985). Dissertação de Mestrado. Universidade Federal de Goiás, 1999.

MACIEL, M. E. Os tipos característicos. Região e estereótipos regionais. In: Revista do Instituto de Filosofia e Ciências Humanas. UFRGS, Porto Alegre v.18, n1/2, 1995.

MAMIGONIAN, A. Tecnologia e desenvolvimento desigual no centro do sistema capitalista. In: Estudos de Geografia Econômica e de Pensamento Geográfico. Livre Docência: FFLCH-USP, 2005.

- Teorias sobre a industrialização. Laboratório de Geografia Política e planejamento territorial e ambiental. Texto 4: Departamento de Geografia, USP, São Paulo, 2000.

_. Notas sobre as raízes e originalidade do pensamento de Ignácio Rangel. In: MAMIGONIAN, A. e REGO, J. M (Orgs.) O pensamento de Ignacio Rangel, $1^{\mathrm{a}}$ ed. São Paulo: Ed. 34, 1998. 
MANTELli, J. Organização no meio rural do Estado do Rio Grande do Sul http://observatoriogeograficoamericalatina.org.mx/egal12/Geografiasocioecono mica/Geografiarural/14.pdf, s/d, acessado em 05/2014.

MANTELLI, J. “O setor agrário da região Noroeste do Rio Grande do Sul”. In: Geosul, v. 21, n. 41, p 87-105, Florianópolis, 2006.

MANTELLI, J.; CANABARRO, I. S. “A organização cultural do espaço agrário no noroeste do Rio Grande do Sul”. In: XIX ENGA, São Paulo, 2009.

MELLO, J. M. C. de. O capitalismo tardio. $11^{\mathrm{a}}$ ed. Campinas: Eds. Unesp e Facamp, 2009.

MENDONÇA, S. R. de. A industrialização brasileira. $2^{\mathrm{a}}$ ed. São Paulo: Ed. Moderna, 2004.

MINISTERIO DO PLANEJAMENTO. Plano de gestão do PPA 2004-2007, 2004 http://www.planejamento.gov.br/secretarias/upload/Arquivos/spi/plano_plurianu al/modelo_gestao/081009_PPA_MG_planoGes.pdf

MINISTÉRIO DO PLANEJAMENTO, ORÇAMENTO E GESTÃO. Secretaria de Planejamento e Investimentos Estratégicos. Plano plurianual 2008-2011 projeto de lei / Ministério do Planejamento, Orçamento e Gestão, Secretaria de Planejamento e Investimentos Estratégicos. - Brasília : MP, 2007.

PROGRAMA DE ACELERAÇÃO DO CRESCIMENTO, 2014. http://www.planejamento.gov.br/ministerio.asp?index $=61$

MINISTERIO DA FAZENDA. Secretaria do Tesouro Nacional - STN. O que você precisa saber sobre as transferências constitucionais e legais? Fundo de Participação dos Municípios - FPM. 2012. Link de acesso http://www3.tesouro.fazenda.gov.br/estados_municipios/download/CartilhaFPM .pdf

MONTOYA, M. A. O Agronegócio Brasileiro e da Região Sul: Dimensão Econômica e Tendências Estruturais. UPF, Passo Fundo, 2002.

MORAES, A. Produção leiteira e desenvolvimento regional: uma análise dos agentes da cadeia produtiva na Região Noroeste do Rio Grande do Sul. Dissertação de Mestrado, UFSM, 2010.

MORAES, A. C. R. Geografia pequena história crítica. São Paulo: Ed. Annablume, 1983.

MOREIRA, I. A. G.; COSTA, R. H. da. Espaço e sociedade no RS. $4^{\mathrm{a}}$ ed. Porto Alegre: Ed. Mercado Aberto, 1995. 
MORLIN, G. S.; PEDERIVA, A. C.; WAQUIL, P. D. Destino da produção agrícola: uma análise comparada entre o Rio Grande do Sul e o Brasil. http://www.pucrs.br/eventos/eeg/download/Mesa15/Destino_da_Producao_Agri cola-Uma_Analise_comparativa_entre_o_RS_e_o_Brasil.pdf Acessado em 06/2013.

MULLER, N. L. Industrialização do Vale do Paraíba. In: Geografia das Indústrias, São Paulo: Instituto de Geografia da Universidade de São Paulo, 1969.

MUller, G. A Economia Política Gaúcha dos Anos 30 aos 60. In: GONZAGA, S.; DACANAL, J. H. (Orgs). RS: economia e política. Porto Alegre: Ed. Mercado Aberto, 1979.

OlIVEIRA, C. A. B. de. Processo de industrialização do capitalismo originário ao atrasado. Campinas: Ed. UNESP, 2002.

OLIVEIRA, F. Crítica à razão dualista. CEBRAP - 4ª ed. Petrópolis: Ed. Vozes, 1981.

PACHECO, C. A. Novos padrões de localização industrial? Tendências recentes dos indicadores da produção e do investimento industrial. Texto para discussão $\mathrm{n}^{\circ}$ 633. Brasília, 1999.

PACHECO, E.; BRESSAN, S. Introdução à teoria da sociedade e estado. Ijuí: Ed. Unijuí, 1987.

PEREIRA, C. S. et al. “A contribuição das empresas fornecedoras nas competências de uma cadeia de suprimentos do setor automotivo". In: $P \& P$, vol.11, n.3, p. 87108, PUC-RS, 2010.

PEREIRA, J. M. D.; ARENDT, M. O desenvolvimento da indústria gaúcha no século $X X$. Link de acesso http//www cdn.fee.tche.br/eeg/1/mesa_12_pereira_arendt. pdf, 2003.

PEREIRA, L. C. B., REGO, J. M. Um mestre da economia brasileira: Ignácio Rangel In: Mamigonian, A., Rego, J. M. (Orgs.) O pensamento de Ignácio Rangel. Ed. 34, 1998.

PESAVENTO, S. J. RS: agricultura colonial e industrialização. Porto Alegre: Mercado Aberto, 1983.

PELÁEZ, C. M. História da industrialização brasileira - Crítica à teoria estruturalista no Brasil, Rio de Janeiro: Ed. Apec,1972.

PILAR, A. M. R.; BENEDUCE, G. M. C. “A constituição das redes de cidades do RS a partir de uma leitura histórica dentro do contexto das diferenciações 
socioculturais e naturais”. In: Observatórium: Revista Eletrônica de Geografia da UFSM, vol. 1, n. 3, pp.117-125 dez, 2009.

POLITICA INDUSTRIAL. Modelo de desenvolvimento industrial do Estado do RS 2012/2014. Link de acesso: www.sdpi.rs.gov.br. Acessado em 04/ 2014.

PRADO JR., C. História Econômica do Brasil. 14ª ed. São Paulo: Ed. Brasiliense, 1971.

PREBISCH, R. O desenvolvimento econômico da América Latina e alguns de seus problemas principais. In: BIELSCHOWSKY, R. (Org.) Cinquenta anos de pensamento na CEPAL, Rio de Janeiro-São Paulo: Ed. Record, 2000.

PRO-RS IV Propostas estratégicas para o desenvolvimento regional do Estado do Rio Grande do Sul (2011-2014) Coredes-RS, Ed. Passografic, 2010.

RANGEL, I. A história da dualidade brasileira. In: MAMIGONIAN, A; REGO, J. M. (Orgs.) O pensamento de Ignácio Rangel /1ª ed. São Paulo: Ed. 34, 1998. Dualidade básica da economia brasileira. Rio de Janeiro: MEC, 1957.

RAKOWSKI, M. et al. "Importância dos supermercados em cooperativas de produção: um estudo comparativo em seis cooperativas no Rio Grande do Sul”. In: BUTTEMBENDER, P. L. (Org.) Cooperativismo na Região Noroeste do Rio Grande do Sul, Porto Alegre: Sescoop/RS, 2010.

REDESIST. Glossário sobre arranjos e sistemas produtivos e inovativos locais. 2003. Link de acesso: http://www.desenvolvimento.gov.br/arquivos/dwnl_ 1289323549.pdf.

REGO, J. M.; MARQUES, R. M. (Org.). Economia brasileira. São Paulo: Saraiva, 2005 .

REICHEL, H. J. A industrialização no RS na República Velha. In: DACANAL, J. H.; GONZAGA, S. (Orgs.) RS: economia e política, Porto Alegre: Ed. Mercado Aberto, 1979.

REVISTA AFINAL. Indústria puxa o crescimento econômico de Santa Rosa. Link de acesso http://www.revistafinal.com/2011/10/industria-puxa-o-crescimentoeconomico.html, 2011.

REVISTA DO SENADO FEDERAL. Desonerações afetam municípios In: Em discussão - Revista de audiências públicas do Senado Federal. Ano 4, nº 16, 2013. http://www.senado.gov.br/noticias/Jornal/emdiscussao/contaspublicas/realidade-brasileira/desoneracoes-tributarias-reducao-de-ipi-afetam- 
municipios-pois-diminuiem-os-valores-repassados-pela-uniao-ao-fpm-fundode-participacao-dos-municipios.aspx.

ROCHE, J. A colonização alemã e o Rio Grande do Sul. Vol II. Porto Alegre: Ed. Globo, 1969.

ROHLEDER, D. Desenvolvimento no Noroeste do RS: uma interpretação contemporânea e alternativa. Santa Cruz do Sul: Edunisc, 2003.

ROTTA, E. A construção do desenvolvimento. Análise de um modelo de interação entre o regional e o global. Ijui: Ed. Unijuí, 1999.

ROTTA, E. et al. Região Fronteira Noroeste - revendo a história para projetar o futuro. In: DALLABRIDA, V. R. e BUTTEMBENDER, P. L. (Orgs.) Gestão, inovação e desenvolvimento - Oportunidades e desafios para o desenvolvimento da Região Fronteira Noroeste. Santa Cruz do Sul: Ed. Edunisc, 2007.

ROTTA, E. et al. Os arranjos produtivos locais e as estruturas de gestão do desenvolvimento. In: BUTTEMBENDER, P. L. (Org.) Arranjos institucionais, cooperação e desenvolvimento - Redes econômicas, tecnológicas e sociais: sementes do desenvolvimento agregando valor. Ijuí: Ed. Unijuí, 2010a.

ROTTA, E. et al. Os desafios da gestão do desenvolvimento articulando os arranjos produtivos locais. Projeto de Pesquisa "Estudo sobre estruturas de gestão do desenvolvimento, considerando os arranjos produtivos da região Fronteira Noroeste". In: BUTTEMBENDER, P. L. (Org.) Arranjos institucionais, cooperação e desenvolvimento - Redes econômicas, tecnológicas e sociais: sementes do desenvolvimento agregando valor. Ed. Unijuí, 2010 b.

RUCKERT, I. N.; BORSATTO, M. L.; RABELO, M. "As finanças municipais e os gastos sociais no Rio Grande do Sul 1995-99”. In: Documentos FEE n 50. Porto Alegre, 2002.

RUCKERT, I. N.; RABELO, M. “A situação das finanças públicas e a descentralização das políticas sociais nos municípios do Rio Grande do Sul, 1995-2001”. In: Análise, v. 16, n. 2, pp. 241-263. Porto Alegre, 2005.

SALA DO INVESTIDOR. Link de acesso http://www.saladoinvestidor.rs.gov.br/2013.

SANTOS, M. A natureza do espaço: técnica, tempo, razão e emoção. São Paulo: Ed. Edusp, 2009.

. Pensando o espaço do homem. São Paulo: Edusp, 2007.

SCARLATO, F. C. O espaço industrial brasileiro. In: ROSS, J. L. S. (Org.) Geografia do Brasil, $4^{\mathrm{a}}$ ed. São Paulo: Edusp, 2001. 
SCHALLEMBERGER, E.; HARTMANN, H. R. Nova terra, novos rumos. A experiência de colonização e povoamento na grande Santa Rosa. Santa Rosa: Ed. Barcellos Livreiros, 1981.

SEFAZ-RS. Secretaria da Fazenda do Estado do Rio Grande do Sul. Link de acesso: https://www.sefaz.rs.gov.br/Site/index.aspx? 2014.

SEGAT, V. M. M.; CHRISTENSEN, T. N.; SARTORI, S. J. Pelos caminhos de Santa Rosa. Santa Rosa: Ed. Barcelos Livreiros, 1981.

SEPLAG/DEPLAN Secretaria de Planejamento, Gestão e Participação Cidadã Departamento de Planejamento Governamental. Link de acesso http://www.seplag.rs.gov.br. Acessado em 12/2013

SESCOOP/OCERGS. Sindicato e Organização das Cooperativas do Estado do Rio Grande do Sul. http://www.ocergs.coop.br/index.php/sindiocergs46/sindiocergs Link acessado em 04/2014.

SIMONSEN, R. C. A evolução industrial do Brasil e outros estudos. Ed. Cia Nacional: 1973.

SINGER, P. Curso de introdução à economia política. $15^{\mathrm{a}}$ ed. Rio de Janeiro: Ed. Forense Universitária, 1995.

SLEIMAN, J. Veranicos ocorridos na porção Noroeste do Rio Grande do Sul entre 1978 e 2005 associados às condições climáticas na atmosfera. Dissertação (Mestrado em Ciências), Faculdade de Filosofia, Letras e Ciências Humanas, Universidade de São Paulo, São Paulo, 2008.

SOUZA, N. J. Consequências econômicas da abertura comercial da economia brasileira, 1990/1998. Porto Alegre: PUCRS, 2001.

SOUZA, N. J. Estrutura espacial das atividades econômicas do Rio Grande do Sul, 1990/2000. Estudos da CEPE, Santa Cruz do Sul, v. n. 21, pp. 91-115, 2005.

SOUZA, N. J. Exportações e crescimento econômico do Rio Grande do Sul, 1951-2001. Ensaios FEE, Porto Alegre, v.23, número especial, p.565-602, 2002.

SPAREMBERGER, A. Organização, comercialização e concorrência no sistema agroalimentar. In: SPAREMBERGER, A. et al. (Org.) Princípios de agronegócios - Conceitos e estudos de caso. Ed. Unijuí, 2010.

STERNBERG, S. S. W. Diferenciais regionais na evolução do emprego formal no RS, no período 1994-05. In: PAIVA, C. (Org). Evolução das desigualdades territoriais no Rio Grande do Sul. Santa Cruz do Sul: Ed. Edunisc, 2008. 
SUNKEL, O. Desenvolvimento, subdesenvolvimento, dependência, marginalização e desigualdades espaciais: por um enfoque totalizante. In: BIELSCHOWSKY, R. (Org.). Cinquenta anos de pensamento na CEPAL, Rio de janeiro, São Paulo: Ed. Record, 2000.

SUZIGAN, W. Indústria brasileira origem e desenvolvimento. São Paulo e Campinas: Eds. Hucitec e Unicamp, 2000.

SUZIGAN, W. Industrialização na visão de Celso Furtado. Instituto de Economia/UNICAMP. Disponível em http://www.eco.unicamp.br/neit/ download/artigos/Industrializacao_Celso_Furtado.pdf, 2001. Acessado em 03/2014.

SUZIGAN, W.; FURTADO, J. "Política industrial e desenvolvimento". Revista Economia e Política. vol. 26, nº 2 (102), São Paulo, 2006.

TAMBARA, E. RS Modernização e Crise na Agricultura. Porto Alegre: Mercado Aberto, 1985.

TATSCH, A. L. (Coord.) Os arranjos produtivos locais no Rio Grande do Sul: mapeamento, metodologia de identificação e critérios de seleção para políticas de apoio. Rio de Janeiro: UFRJ, 2010. Link de acesso: http://www.bndes.gov.br/SiteBNDES/bndes/bndes_pt/Galerias/Arquivos/empres a/pesquisa/Mapeamento_RS.pdf

TAVARES, M. da C. Da substituição de importações ao capitalismo financeiro. Ensaios sobre economia brasileira $2^{\mathrm{a}}$ ed. Ed. Zahar, 1973.

TRANFERÊNCIAS CONTITUCIONAIS. Estados e Municipios. Link de acesso: http://www3.tesouro.gov.br/estados_municipios/transferencias_constitucionais_ novosite.asp, 2014.

TRENNEPOHL, D.; ALVES, R. A.; FLORES, A. J. Análise das características regionais e setoriais da evolução do valor bruto da produção agropecuária municipal no Rio Grande do Sul entre 1970 e 1996. In: Paiva, C. (Org) Evolução das Desigualdades Territoriais no Rio Grande do Sul. Santa Cruz do Sul: Ed. Edunisc, 2008.

UNISINOS. Fecundidade e migração baixas inibem crescimento do RS. http://www.ihu.unisinos.br/noticias/505361fecundidadeemigracaobaixasinibemc rescimentodors, 2014

VASCONCELLOS, M. A. S. Economia brasileira contemporânea. São Paulo: Atlas, 1999. 
VEIGA, J. E. A interiorização do desenvolvimento. São Paulo: Ed. Valor, 2005 http://www.econ.fea.usp.br/zeeli/artigos_valor/055_2005_09_06.htm.

- A proeza da gaúcha Santa Rosa. São Paulo: Ed. Valor, 13/06/2006a www.econ.fea.usp.br/zeeli/.

. "Territórios para um desenvolvimento sustentável”. In: Ciência \& Cultura, São Paulo, p. 20 - 24, 2006. Homepage: <www.econ.fea.usp.br/zeeli/>; 2006.

. "Vicissitudes da governança cidadã - Os conselhos regionais gaúchos (Coredes)". In: Revista de Desenvolvimento Econômico, ano VIII, n. 13, pp. 19-27, jan. 2007.

. "Potencial de cooperação e articulação no desenvolvimento rural". In: Cadernos do CEAM, ano V - nº 23, pp. 221-278, 2006.

. O Desenvolvimento Agrícola. São Paulo: Hucitec, 1991.

VETTORATO, H. K.; DALLABRIDA, V. R. Questões conceituais e a prática de regionalização no RS, Ijuí: Ed. Unijui, 2001 (Série Ciências Sociais no 22).

VERSIANI, F.; SUZIGAN, W. O processo brasileiro de industrialização: uma visão geral. Brasília: Universidade de Brasília, 1990. http://vsites.unb.br/face/eco/bmueller/versiani_suzigan. Acessado em 12/2013 (Série Textos Didáticos, 10).

VIEIRA, E. F.; RANGEL, S. R. S. Rio Grande do Sul - Geografia da população. Porto Alegre: Ed. Sagra, 1985.

WINCKLER, C. R.; MOURA NETO, B. T. "Welfare State à brasileira". In: Indicadores econômicos FEE, 1992. Link de acesso: http://revistas.fee. tche.br/index.php/indicadores/article/view/527, acessado em 05/2014.

ZARTH, P. A. Do arcaico ao moderno: o Rio Grande do Sul agrário do século XIX. Ijuí: Ed. Unijuí, 2002.

. Historia agrária do Planalto Gaúcho, Vol. 1, 1ª ed., Ijuí: Ed. Unijuí, 1997.

ZUCATO, L.; FERASSO, M.; EVANGELISTA, M. A importância das exportações para o desenvolvimento local da Fronteira Noroeste do Rio Grande do Sul e do Extremo-Oeste de Santa Catarina In: Casos - Revista portuguesa e brasileira de gestão, 2010. Link de acesso: http://www.scielo.gpeari.mctes.pt/pdf/rpbg/v9n12/v9n1-2a10.pdf

ZULUPA.http://zulupa.com.br/noticias/economia/2013/9/10652/santarosa-distritomoveleiro-pode-ser-ampliado 